\title{
WRR
}

WETENSCHAPPELIJKE RAAD VOOR HET REGERINGSBELEID

\section{De Europese Unie, \\ Turkije en de islam}


De Wetenschappelijke Raad voor het Regeringsbeleid werd in voorlopige vorm ingesteld in 1972. Bij wet van 30 juni 1976 (Stb. 413) is de positie van de raad definitief geregeld. De huidige zittingsperiode loopt tot 31 december 2007.

Ingevolge de wet heeft de raad tot taak ten behoeve van het regeringsbeleid wetenschappelijke informatie te verschaffen over ontwikkelingen die op langere termijn de samenleving kunnen beïnvloeden. De raad wordt geacht daarbij tijdig te wijzen op tegenstrijdigheden en te verwachten knelpunten en zich te richten op het formuleren van probleemstellingen ten aanzien van de grote beleidsvraagstukken, alsmede op het aangeven van beleidsalternatieven.

Volgens de wet stelt de WRR zijn eigen werkprogramma vast, na overleg met de minister-president die hiertoe de Raad van Ministers hoort.

De samenstelling van de raad is (tot 31 december 2007):

prof.mr. M. Scheltema (voorzitter)

prof.dr. W.B.H.J. van de Donk

prof.dr. P.L. Meurs

prof.dr. J.L.M. Pelkmans

prof.dr.mr. C.J.M. Schuyt

prof.dr.J.J.M. Theeuwes

prof.dr. P.Winsemius

Secretaris: dr. A.C. Hemerijck

De WRR is per 1 juli 2004 gevestigd:

Lange Vijverberg 4-5

Postbus 20004

2500 EA 's-Gravenhage

Telefoon 070-356 46 oo

Telefax 070-356 4685

E-mail info@wrr.nl

Website http://www.wrr.nl 


\section{WRR}

WETENSCHAPPELIJKE RAAD VOOR HET REGERINGSBELEID

\section{De Europese Unie, Turkije en de islam}


ISBN 90-5356-692-9 


\section{WRR}

WETENSCHAPPELIJKE RAAD VOOR HET REGERINGSBELEID

Aan de Minister-president

Minister van Algemene Zaken

De heer mr. dr. J.P. Balkenende

Postbus 20001

2500 EA Den Haag

ons kenmerk

$2004061 / \mathrm{ms} / \mathrm{al}$

doorkiesnummer

telefax

070-356 4690

070-356 4685

onderwerp

Rapport nr. 69

email

datum

info@wrr.nl

1 juni 2004

Hierbij zenden wij u het rapport 'De Europese Unie, Turkije en de islam'. Hierin gaat de raad in op de vraag of het feit dat de meerderheid van zijn bevolking moslim is een belemmering vormt voor toetreding van Turkije tot de Europese Unie. Op grond van de in dit rapport geschetste ontwikkelingen en huidige karakteristieken van de islam in Turkije concludeert de raad dat hierin geen belemmering ligt voor toetreding. Ook meent de raad dat er geen aanwijzingen zijn dat met het.doorvoeren van door de EU gewenste hervormingen de Turkse democratische rechtsstaat in de toekomst in de gevarenzone zal komen.

Met dit rapport doet de raad geen aanbeveling over het nu al dan niet starten van de toetredingsonderhandelingen. Dat besluit is immers afhankelijk van de vorderingen die Turkije heeft gemaakt ten aanzien van het politieke Kopenhagen-criterium. Aangezien de aarzelingen die over het Turks lidmaatschap zijn ontstaan mede zijn terug te voeren op de religieuze factor, meent de raad met bijgaand rapport bij te dragen aan een beter inzicht hieromtrent.

Het rapport is op 6 april door de WRR vastgesteld. Volgens de procedure van de Instellingswet WRR ziet de raad graag de bevindingen van de ministerraad tegemoet.

De voorzitter

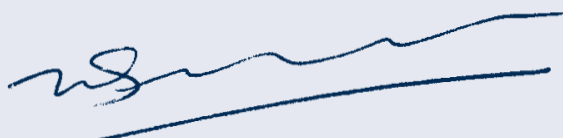

prof. mr. M. Scheltema

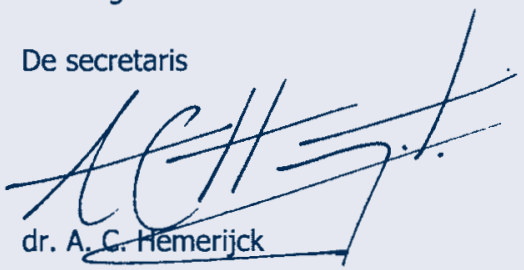




\section{INHOUDSOPGAVE}

De Europese Unie, Turkije en de islam

\section{Samenvatting}

Ten geleide

$\begin{array}{lll}1 & \text { Inleiding } & 17\end{array}$

$\begin{array}{lll}1.1 & \text { Achtergrond en aanleiding } & 17\end{array}$

$\begin{array}{ll}1.2 & \text { Doel, centrale vraag en beperkingen }\end{array}$

$\begin{array}{lll}1.3 & \text { Uitwerking onderzoeksvraag en rapportopbouw }\end{array}$

2 De Europese Unie en religie $\quad 25$

$\begin{array}{lll}2.1 & \text { Inleiding } 25\end{array}$

2.2 De waarden van de Unie 25

2.3 Religie in de Europese lidstaten 28

2.3.1 Wederzijdse autonomie en borging van vrijheden 28

2.3.2 Een Europees model? 30

$\begin{array}{lll}2.4 & \text { Conclusie } & 37\end{array}$

3 De Turkse islam en de Europese Unie 41

3.1 Inleiding 41

3.2 De seculiere staat: historisch fundament 41

$\begin{array}{lll}3.3 & \text { Seculiere staat en politieke islam } & 45\end{array}$

3.4 Staatsislam en vrijheid van godsdienst 48

3.5 Democratie en politieke islam $\quad 51$

3.6 Rechtsstaat en politieke islam 54

3.7 Geweld en politieke islam 58

$\begin{array}{lll}3.8 & \text { Conclusie } & 60\end{array}$

4 Conclusies $\quad 63$

$\begin{array}{ll}\text { Vooruitblik } & 69\end{array}$

$\begin{array}{ll}\text { Literatuur } & 73\end{array}$

Zoeken naar de breuklijn $\quad 79$

Verkenning door E.J. Zürcher en H. van der Linden 
DE EUROPESE UNIE, TURKIJE EN DE ISLAM 


\section{SAMENVATTING}

\section{Centrale vraag}

Vormt het feit dat de meerderheid van zijn bevolking moslim is een belemmering voor de toetreding van Turkije tot de Europese Unie (EU)?

\section{Aanleiding}

Deze vraag, die in dit rapport wordt onderzocht, is actueel tegen de achtergrond van de beslissing die de EU onder Nederlands voorzitterschap in december 2004 dit jaar zal nemen. Dan wordt namelijk beoordeeld of kandidaat-lidstaat Turkije dermate vorderingen heeft gemaakt ten aanzien van het zogenoemde politieke Kopenhagen-criterium dat de toetredingsonderhandelingen van start kunnen gaan. Bij dit criterium gaat het om een stabiele democratie en een rechtsstaat die garant staat voor de rule of law, mensenrechten en de rechten van minderheden.

De aard van religie als zodanig maakt van dit Kopenhagen-criterium geen deel uit. Het feit dat de meerderheid van de Turkse bevolking moslim is, speelde dan ook formeel geen rol bij de toekenning in 1999 aan Turkije van de status van kandidaat-lidstaat. Vooral echter sinds de terroristische aanslagen op 11 september 2001 zijn de zorgen over de islam en moslims in de lidstaten toegenomen. Dit heeft geleid tot een groeiende aarzeling over de vraag of het islamitische karakter van Turkije zich verdraagt met de politieke verworvenheden van de EU en haar lidstaten. Bezwaren van cultureel-religieuze aard worden inmiddels ook in politieke kringen naar voren gebracht.

\section{Doel}

In het licht van deze recente discussies acht de WRR het van belang de vraag naar de verenigbaarheid van de Turkse islam met de waarden waarop de Unie is gebaseerd, zelfstandig aan de orde te stellen. Hiermee beoogt de raad bij te dragen aan een geïnformeerde oordeelsvorming in Nederland.

Met dit rapport geeft de raad geen advies aan de regering over de vraag of met Turkije nu de toetredingsonderhandelingen kunnen worden geopend. Die in december van dit jaar te nemen beslissing vergt immers een totaalafweging van het vraagstuk van de Turkse toetreding. Zo'n totaalafweging wordt in dit rapport niet gemaakt; het gaat hier uitsluitend om de relatie tussen de Turkse islam en de democratische, seculiere rechtsstaat.

Wel blikt de raad aan het eind van dit rapport vooruit op de mogelijke implicaties van een Turks lidmaatschap voor de problematisch geworden relatie tussen de moslimwereld en het Westen. Op dit algemene vraagstuk komt hij in een apart advies terug. 


\section{Religie in de Europese Unie en de lidstaten}

Bij de beantwoording van de vraag of de Turkse islam een belemmerende factor is voor toetreding, dient allereerst te worden vastgesteld wat de plaats is van religie in de EU zelf. Religie maakt geen deel uit van de gemeenschappelijke EU-waarden. De Unie heeft zichzelf immers gedefinieerd als een waarden- en handelingsverbond dat berust op de beginselen van vrijheid, democratie, alsmede eerbiediging van de rechten van de mens, de fundamentele vrijheden en de rechtsstaat. De vrijheid van gedachte, geweten en godsdienst behoort hiermee juist tot de grondrechten, evenals het door de Unie respecteren van de verscheidenheid van cultuur en godsdienst.

Vanuit de beginselen en de grondrechten van de Unie gezien mag er dan geen reden zijn een land op grond van zijn dominante religie bij voorbaat uit te sluiten, maar er speelt wel iets anders, namelijk de scheiding van kerk en staat. Aan de beginselen van de Unie en de politiek-burgerlijke grondrechten ligt immers de veronderstelling ten grondslag dat de lidstaten beschikken over een democratische rechtsstaat die zowel de autonomie van kerk of geloofsgemeenschap en staat als de vrijheid van godsdienst en geweten erkent en borgt. Het uitgangspunt van autonomie impliceert dat geloofsgemeenschap en staat elk aparte bevoegdheidssferen hebben. De vrijheid van godsdienst en geweten betekent dat gelovigen van (minderheids)religies, atheïsten en geloofsafvalligen geen beperkingen ontmoeten in hun rechten. Het is juist over dit leerstuk dat twijfels bestaan over de islam.

Toch blijkt de situatie tussen de lidstaten van de EU uit het oogpunt van autonomie van kerk en staat zelf uitermate divers. Ook al zijn alle lidstaten formeel seculier en kennen ze vrijheid van godsdienst, lang niet altijd staan ze neutraal tegenover religies of richtingen daarbinnen. Zo zijn er lidstaten met en zonder een staatskerk. Waar geen staatskerk bestaat, kan een bepaald kerkgenootschap echter toch feitelijk bevoorrecht worden, terwijl een staatskerk daarentegen een gelijke behandeling van andere kerken niet uitsluit. Iedere lidstaat kent een eigen, vaak spanningsvolle geschiedenis in de relatie tussen kerk, staat, politiek en maatschappij, die heeft geresulteerd in specifieke arrangementen. Uit het oogpunt van scheiding van kerk en staat bestaat er derhalve niet zoiets als een Europees model waar Turkije aan kan worden getoetst. Hoogstens kan toetsing plaatsvinden op minimumvoorwaarden.

\section{Karakteristieken van de Turkse islam}

Vervolgens rijst de vraag of de Turkse islam karakteristieken vertoont die toetreding in de weg staan. Zijn er, met andere woorden, ontwikkelingen in Turkije die de verhouding van de Turkse islam met de voor de EU essentiële waarden negatief beïnvloeden? De WRR meent dat dit niet het geval is. De Turkse staat wordt constitutioneel gevrijwaard van religieuze invloed. In dit opzicht kent het land een niet minder rigoureuze scheiding van religie en staat dan Frankrijk, waarvan het zogenoemde laïcisme trouwens ook model heeft gestaan voor de grondwet van de Republiek Turkije. Anders dan in Frankrijk echter 
bestaat in Turkije een sterke controle en inhoudelijke invloed van de staat op de religie.

Deze karakteristieken kennen een lange voorgeschiedenis. Hoewel Turkije religieuze invloed op de staat het meest extreem uitbande in de jaren twintig en dertig, vanaf het instellen van de Republiek, gaat er een periode van ten minste een eeuw van modernisering aan vooraf naar het voorbeeld van West-Europese landen. De Franse Verlichting heeft het constitutionele denken ook in de Osmaanse periode al sterk beïnvloed. Niet veel later dan in West-Europese staten kwam de eerste grondwet tot stand en werden verkiezingen gehouden voor het eerste Osmaanse parlement (1876). Vervolgens is er tot aan de Eerste Wereldoorlog een periode van sterk religieus gekleurd nationalisme, met een grote bemoeienis van de overheid met de inhoud en verspreiding van het geloof. Het hierop volgende kemalisme, genoemd naar de opvattingen van de grondlegger van de Republiek, Mustafa Kemal Pasja (Atatürk), privatiseerde het geloof tijdens het interbellum daarentegen met harde hand, weerde religieuze symbolen uit het openbare leven, hief religieuze instellingen op of plaatste deze onder staatscontrole en verbood de populaire mystieke ordes. In deze periode werden ook de resterende onderdelen van het islamitische recht, met name het familierecht, vervangen door seculier recht. Het islamitisch strafrecht was al veel eerder afgeschaft, namelijk midden negentiende eeuw. Na de Tweede Wereldoorlog voerde Turkije een meerpartijendemocratie in en werd de islam gaandeweg een belangrijkere politieke factor, ook in de programma's van op zichzelf niet-religieuze politieke partijen. Vanaf de jaren zestig kwamen hiernaast ook politieke partijen op die zich uitdrukkelijk afficheerden als islamitisch.

Deze opkomst van de islam als politiek relevant verschijnsel moet volgens de raad worden geplaatst tegen de achtergrond van zijn geforceerde marginalisering in de voorafgaande decennia. Deze ontkenning van bovenaf van de moslimidentiteit sloot nooit aan bij de opvattingen van een groot deel van de bevolking. Tegelijk werd deze opkomst van onderop gedragen door belangrijke sociaal-economische veranderingen in Turkije, zoals de ontwikkeling van een aanzienlijke middenstand op het platteland en in de kleine steden waarvoor de islam een normaal onderdeel van het bestaan vormt. Islamitische partijen ontmoeten tot op heden grote argwaan van het establishment in en rond het overheidsapparaat, dat zich sterk identificeert met het kemalistische gedachtegoed. Bij verschillende gelegenheden heeft zowel het Constitutionele Hof als het leger ingegrepen en zijn dergelijke partijen verboden. Als tegenwicht tegen radicale linkse en religieuze opvattingen is - door tussenkomst van het leger - vanaf 1982 een staatsislam geïnstitutionaliseerd die nog altijd een bevoorrechte positie heeft. Deze paart een sterk accent op maatschappelijk conservatisme en nationalisme aan een gematigde islam en wordt uitgedragen via de moskee en het verplichte godsdienstonderwijs. Ook via deze staatsislam, die de hoofdstroom van de opvattingen onder de bevolking en de conservatieve politieke formaties weerspiegelt, en tegelijk stevig ingebed is in een seculiere staatsordening, heeft het publieke belang van de islam erkenning gekregen. 
Tot slot merkt de raad op dat voor de islamitische politieke partijen die de afgelopen decennia ontstonden, het principe van scheiding tussen religie en staat een belangrijk gegeven vormde. Ze gaven daaraan echter een andere uitwerking. Zij aanvaardden de seculiere staat, maar wilden tegelijkertijd de vrijheid van godsdienst vergroten en keerden zich derhalve tegen de sterke staatscontrole op religie. Evenzo gingen zij uit van het bestaande democratische bestel, maar dat moest dan wel toegang bieden aan partijen die zich op religie baseerden. Zij beschouwden vrijheid van geweten en van meningsuiting als basis van democratie en mensenrechten. Ook trokken zij het seculiere karakter van het recht niet in twijfel, evenmin als het principe van gelijke rechten van mannen en vrouwen.

Kan dit accent op deze vrijheden nog worden uitgelegd als gericht op het scheppen van een rechtmatige ruimte voor de eigen opvattingen, de op dit moment regerende Partij voor Gerechtigheid en Ontwikkeling (de AK-partij), die is voortgekomen uit een eerder verboden islamitische partij, benadrukt veel sterker de mensenrechten uit het oogpunt van pluraliteit. $\mathrm{Zij}$ waardeert verschillen van geloof, cultuur en meningen op zichzelf, en ziet secularisme als het principe van vrijheid dat deze verschillen mogelijk maakt.

\section{Conclusie van de raad}

De raad meent dat het gegeven dat Turkije een land is met een bevolking van in meerderheid moslims, geen belemmering vormt voor toetreding tot de EU. Hij baseert zich hierbij op de volgende overwegingen.

Om te beginnen stelt de raad op grond van de geschetste ontwikkelingen en huidige karakteristieken van de islam in Turkije vast dat het principe van de seculiere democratische rechtsstaat in Turkije stevig is geworteld. Bovendien vertoont de ontwikkeling van de democratische rechtsstaat een grote parallellie met de West-Europese geschiedenis en eveneens een aanzienlijke gelijktijdigheid. De Turkse islam heeft deze ontwikkeling niet in de weg gestaan, maar tot op heden juist mee helpen bevorderen. Dat de islam met de democratisering na de Tweede Wereldoorlog een belangrijke politieke kracht is geworden, is op zichzelf een normaal verschijnsel. Ook tegen de achtergrond van de politieke rol van religie in veel Europese lidstaten is het niet verwonderlijk dat het de kemalisten niet is gelukt de religie geheel uit het politieke en openbare leven te weren.

Echter, vanuit het perspectief van de EU is het vraagstuk van de islam in Turkije niet zozeer een probleem van invloed van deze religie op de staat, maar veeleer een probleem van de invloed van de staat op de religie. De staatsbemoeienis met de religie gaat in Turkije immers verder dan in de EU-lidstaten, al kennen ook verschillende EU-landen een staatsreligie. Bovendien passen de grondwettelijke beperkingen aan het democratische proces met als doel het seculiere staatsbestel te beschermen, niet bij de uitgangspunten van de EU. Ook de rol van het leger als hoeder van dit bestel past niet bij deze uitgangspunten. Veranderingen hierin vormen dan ook belangrijke wensen van het Europees Parlement en de Europese Commissie. 
Niettemin meent de raad dat er geen aanwijzingen zijn dat bij een versoepeling van deze restricties en een geleidelijk terugtreden van het leger - zoals ook voorgestaan door de huidige Turkse regering - de Turkse islam zijn over het algemeen gematigde karakter zal verliezen, waardoor de seculiere democratische rechtsstaat in de gevarenzone zal komen. De bevolking moet immers in overgrote meerderheid niets hebben van fundamentalisme en religieuze intolerantie en heeft een voorkeur voor gematigde partijen. $\mathrm{Zij}$ steunt het seculiere karakter van de staat en wijst invoering van islamitisch recht af. Daarbij komt dat gewelddadig islamitisch fundamentalisme in Turkije maar weinig aanhangers heeft.

\section{Opbouw van dit rapport}

Het eerste deel betreft het rapport van de raad aan de regering. In hoofdstuk 1 wordt de aanleiding tot en de vraagstelling van het rapport weergegeven. Hoofdstuk 2 gaat in op de plaats van religie in de EU en de arrangementen die binnen de lidstaten bestaan ten aanzien van de relatie tussen staat, religie, politiek en maatschappij. Hoofdstuk 3 beschrijft de ontwikkelingen in Turkije die van belang zijn voor de verhouding van de Turkse islam met de voor de EU essentiële waarden. In hoofdstuk 4 formuleert de raad zijn conclusies. Hierna volgt een vooruitblik over de mogelijke implicaties van een Turks lidmaatschap voor de problematisch geworden relatie tussen de moslimwereld en het Westen. Op dit algemene vraagstuk komt de raad in een apart rapport terug. Deel 2 van het rapport betreft de verkenning Zoeken naar de breuklijn, die prof. dr. E.J. Zürcher en H. van der Linden op verzoek van de WRR hebben geschreven over de Turkse islam en de EU. 
DE EUROPESE UNIE, TURKIJE EN DE ISLAM 


\section{TEN GELEIDE}

Dit rapport is voorbereid door een interne projectgroep van de WRR. Deze bestond uit de stafmedewerkers dr. W. Asbeek Brusse en drs. I.J. Schoonenboom.

De analyses in dit rapport zijn mede gebaseerd op een studie die op verzoek van de WRR is verricht door prof. dr. E.J. Zürcher en H. van der Linden. Deze verkenning, Zoeken naar de breuklijn. Een verkenning naar de rol van de Turkse islam in de toetreding van Turkije tot de EU in het licht van de 'Botsing der Beschavingen', is bij dit rapport gevoegd.

Het Rapport aan de Regering valt onder verantwoordelijkheid van de raad. Voor de verkenning zijn de genoemde auteurs vanzelfsprekend verantwoordelijk. 
DE EUROPESE UNIE, TURKIJE EN DE ISLAM 


\section{Het Turkije-debat}

Tijdens het Nederlandse voorzitterschap van de Europese Unie (EU) in de tweede helft van 2004 moet de beslissing vallen of de EU en kandidaat-lidstaat Turkije zullen starten met lidmaatschapsonderhandelingen. Formeel hangt die beslissing af van de vraag of het land beschikt over een stabiele democratie en een rechtsstaat die garant staat voor de rule of law, mensenrechten en de rechten van minderheden (het zgn. politieke Kopenhagen-criterium). ${ }^{1}$ In het publieke debat spelen echter ook andere overwegingen een rol. Behalve de vele praktische bezwaren tegen Turks lidmaatschap (het land is groot, relatief arm en agrarisch, en grenst aan instabiele buurlanden) worden ook steeds vaker cultureel-religieuze bezwaren genoemd. Turkije zou een van 'Europa' afwijkende cultureelreligieuze geschiedenis en waardenstelsel hebben. ${ }^{2}$

Tot nu toe hebben de nationale regeringen van de lidstaten, de Europese Commissie en het Europees Parlement zich in dit debat vrijwel allemaal afwachtend opgesteld. Voorzover cultuur en religie al een rol spelen voor politici en Europese 'professionals' betreffen ze vooral de zorg of Turkije de religieuze vrijheden weet te garanderen. ${ }^{3}$ Slechts een enkeling twijfelt hardop of een islamitisch land als Turkije überhaupt wel past bij de EU als 'joods-christelijke waardengemeenschap'. Deze terughoudendheid is begrijpelijk. Nadat Turkije in 1963 de status van geassocieerde EU-partner ontving, hebben de Europese regeringsleiders het land eind 1999 de status van kandidaat-lidstaat verleend (zie ook tekstbox 1.1). Daarmee hebben ze zich in principe gecommitteerd aan een mogelijk lidmaatschap. Bovendien mag men juist van vertegenwoordigers van seculiere staten verwachten dat ze enige afstand bewaren tot inhoudelijke oordelen over een religie (zie par. 2.3).

Toch zal het islamitische karakter van Turkije meewegen in de politieke besluitvorming. De Duitse christen-democraten hebben immers al aangekondigd de Turkse toetreding tot inzet te maken van de komende Europese verkiezingen in 2004. Als Turkije binnenkort inderdaad zou mogen beginnen met de toetredingsonderhandelingen en erin zou slagen deze succesvol af te ronden, wordt het vraagstuk bovendien weer politiek relevant op de middellange termijn. Het toetredingsverdrag met de Unie moet daarna immers door alle lidstaten worden bekrachtigd via referenda dan wel goedkeuring door het nationale parlement. De beeldvorming over de Turkse islam en moslims onder volksvertegenwoordigers en kiezers in de lidstaten zal langs die weg ook het toetredingsdebat beïnvloeden.

\section{Turkije, islam en moslims}

De gebrekkige integratie van sommige moslimgroepen in de lidstaten, de groeiende assertiviteit van tweedegeneratiemoslims, het wereldwijd opgekomen 
fundamentalisme en het islamitisch terrorisme hebben 'islam' en 'moslims' steeds meer in een controversieel daglicht geplaatst. Toen de Europese Raad in 1999, in de schaduw van het historische besluit over de oostelijke uitbreiding, tevens besloot Turkije de status van kandidaat-lidstaat te verlenen, moest '11 september 2001' nog plaatsvinden. Juist die aanslag gaf een dramatische wending aan het maatschappelijke en politieke klimaat en activeerde het al langer sluimerend onbehagen. Hierna zijn veel discussies over de verhouding tussen westerse landen en moslimlanden gegoten in de - door Samuel Huntington gemunte termen van een 'botsing der beschavingen' (Huntington 1993 en 1996). Etnisch gelieerde misstanden worden hierdoor sneller geassocieerd met de islam, en zichtbaar aanwezige religieuze moslims gemakkelijker bestempeld als gevaarlijke fundamentalisten. Ook aanslagen als die in Madrid van maart 2004 versterken deze neiging.

Het is te gemakkelijk die angst voor de islam te bagatelliseren. Niet alleen in Nederland en de andere lidstaten maar ook in Turkije zélf zijn openbare en politieke manifestaties van de islam controversieel. Daarvan getuigen bijvoorbeeld de talloze hoofddoekaffaires in Turkije en het periodiek ingrijpen door het Turkse leger tegen democratisch gekozen regeringsleiders van religieuze signatuur. Veel aanhangers van Turkse nationalistische en seculiere partijen vrezen dat religieuze fundamentalisten ruim baan krijgen als het leger zich onder druk van de EU geheel moet terugtrekken uit de politiek. Zij zien met lede ogen toe hoe het Europees Parlement Turkije oproept tot een 'meer ontspannen omgang' met de islam en met godsdienst in het algemeen. Maar ook andere groepen, zoals geëmancipeerde jonge vrouwen, atheïsten en homoseksuelen, wantrouwen de huidige regering van de gematigde religieuze AK-partij en verwachten dat deze elk moment zijn 'ware antiseculiere' gezicht zal tonen.

Voorbeelden uit de Nederlandse, Europese en Turkse context laten zien dat er een forse kloof gaapt tussen het brede publieke debat over 'de islam' en moslimfundamentalisme enerzijds en de discussie onder Europakenners en professionals over het autoritair-seculiere karakter van de Turkse staat anderzijds. Het eerste debat blijft veelal steken in algemeenheden over de islam, moslims, geweld en fundamentalisme die geen recht doen aan de eigenschappen van de Turkse islam, cultuur en samenleving. In het tweede debat komen twee verschillende perspectieven samen: dat van de onvolkomen waarborgen in Turkije voor de bescherming van individuen en (religieuze) minderheidsgroepen, en de mogelijke kansen voor de EU om via Turks lidmaatschap een brug te slaan naar de islamitische wereld. Beide debatten vormen deelaspecten van een omvangrijker en complexer vraagstuk, namelijk de zoektocht van Turkije naar een nieuwe balans tussen religie, staat en samenleving in een snel veranderende omgeving. Hoe deze zoektocht verloopt en vooral welke kansen en bedreigingen Turkije op die weg ontmoet, heeft onmiddellijke relevantie voor de vraag naar de verenigbaarheid van het islamitische Turkije met de EU. Indirect is het vraagstuk daarnaast ook relevant voor de verhouding van Europa met de islamitische wereld. 


\subsection{DOEL, CENTRALE VRAAG EN BEPERKINGEN}

\section{Doel en centrale vraag}

Dit rapport heeft als doel bij te dragen aan een geïnformeerde oordeelsvorming in Nederland over de Turkse islam. In het licht van de recente discussies acht de raad het van belang deze vraag zelfstandig aan de orde te stellen. De centrale vraag luidt:

Vormt het feit dat Turkije een land is met een bevolking die in meerderheid moslim is, een belemmering voor de toetreding van dat land tot de Europese Unie?

De volgende deelvragen dienen als leidraad ter beantwoording van deze vraag.

1 Hoe gaan de EU en de lidstaten om met religie?

2 Welke (impliciete) eisen stelt de EU aan de positie van de religie in de lidstaten?

3 Welke vragen roept deze positie op over de Turkse islam en zijn rol in Turkije?

4 Tot welke beoordeling leiden deze ten aanzien van de toetreding van Turkije tot de EU?

De centrale vraag in dit rapport zou gemakkelijk de indruk kunnen wekken dat de WRR zich hard maakt voor het toevoegen van een extra toets voor Turkije in de vorm van een nieuwe, 'religieuze' component aan het politieke Kopenhagencriterium. Dat is nadrukkelijk niet het geval. Waar het de raad om gaat, is expliciet te maken welke onderliggende veronderstellingen op religieus terrein het politieke Kopenhagen-criterium met zich meebrengt. De formele eis van het beschikken over een democratische rechtsstaat veronderstelt in de huidige Europese context namelijk de autonomie van religie en staat (die ook wel wordt aangeduid als secularisme) en de borging door de staat van religieuze vrijheden en rechten. ${ }^{4}$ Tegen die achtergrond is de plaats van de religie ten opzichte van staat en samenleving in Turkije relevant als onderdeel van het bestaande politieke Kopenhagen-criterium, maar beslist niet in aanvulling op dit criterium. Met het aldus expliciet onderzoeken van de Turkse islam in het licht van de legitieme vereisten van de seculiere democratische rechtstaat, wil de WRR juist vermijden dat de beslissing over Turks lidmaatschap zou worden overschaduwd door onbestemde gevoelens, impliciete argumenten of onbenoemde, religieus getinte verwachtingen waaraan het land al bij voorbaat nooit zal kunnen voldoen. Anders dan de Europese Commissie besteedt de raad in dit rapport dus uitgebreid aandacht aan de ontwikkeling van de relatie tussen de Turkse islam en de seculiere democratische rechtsstaat, en aan de historische verankering van de seculiere staat. Daarnaast staat hij stil bij de zich snel veranderende balans tussen religie, staat en samenleving in Turkije. Kortom, de raad stelt de Turkse islam centraal door deze te 'historiseren en lokaliseren'. Vanuit dit perspectief geeft hij antwoord op de vraag of de Turkse islam een belemmering vormt voor Turks lidmaatschap van de EU. 


\section{Beperkingen}

De raad realiseert zich dat een beoordeling van de plaats van de religie in Turkije slechts één aspect vormt van de totaalafweging van het vraagstuk van de Turkse toetreding. Zo'n totaalafweging wordt in dit rapport niet gemaakt. De raad zal dus geen aanbevelingen doen over het wel of niet binnenkort kunnen openen van de toetredingsonderhandelingen. Dergelijke aanbevelingen vergen een politiek oordeel op basis van een nauwkeurige beoordeling van de vorderingen van Turkije ten aanzien van alle Kopenhagen-criteria. In het najaar van 2004 zal hierin worden voorzien door een nieuwe rapportage van de Europese Commissie. De raad geeft evenmin een beschouwing over alle voor- en nadelen van Turks lidmaatschap. Zo'n beschouwing voert langs tal van andere, op zichzelf belangrijke afwegingen over de slagvaardigheid van de uitgebreide EU, de geopolitieke, economische en financiële gevolgen, de migratieverwachtingen enz., die buiten het kader van dit rapport vallen. ${ }^{5}$ Wel wil de raad het vraagstuk van het Turkse lidmaatschap van de EU mede bezien tegen de achtergrond van de toegenomen wereldwijde betekenis van de politieke islam sinds de jaren zeventig. Over dit algemene vraagstuk zal hij in een apart Rapport aan de Regering adviseren. Het hier voorliggende rapport over de Turkse islam neemt hierop alvast een voorschot.

\subsection{UITWERKING ONDERZOEKSVRAAG EN RAPPORTOPBOUW}

De vraag of het gegeven dat Turkije een in meerderheid moslimse bevolking heeft, een belemmering vormt voor EU-lidmaatschap, vergt allereerst een visie op de Unie. Duidelijk is immers dat er sterk uiteenlopende perspectieven kunnen worden ontwikkeld over wat de Unie is en hoe zij zich in de toekomst moet ontplooien. Elk perspectief hanteert uiteenlopende criteria ter beoordeling van de verenigbaarheid van Turkije en de Turkse islam met de EU. Wie bijvoorbeeld de Unie wil zien als een door christelijke waarden bepaalde gemeenschap van geestverwanten, zal andere beoordelingscriteria aanleggen dan wie haar beschouwt als een verbond van in cultureel opzicht behoorlijk diverse staten die gezamenlijke besluiten nemen. Daarom presenteert de WRR in hoofdstuk 2 eerst de waarden van de Unie die de lidstaten zélf in de afgelopen jaren hebben ontwikkeld (par. 2.2). De Unie vormt een waarden- en handelingsverbond dat de lidstaten rechten verschaft en plichten oplegt en waaraan ook individuele burgers van de Unie aanvullende rechten ontlenen. Het waardenverbond berust niet zozeer op gedeelde historische erfenissen of specifieke cultureel-religieuze waarden, maar op institutioneel verankerde politieke en burgerlijke minimumwaarden van de democratische rechtsstaat. In deze minimumwaarden liggen tevens twee cruciale veronderstellingen besloten over de positie van de religie in (aankomende) lidstaten als Turkije: er is sprake van autonomie van staat en religie en borging van religieuze vrijheden en rechten. Wat daaronder precies moet worden verstaan, blijkt echter niet eenvoudig te bepalen, aangezien de lidstaten sterk uiteenlopende betrekkingen kennen tussen staat, religie en samenleving. Een eenduidige Europese standaard die verder gaat dan deze minimumwaarden, of een ontwikkelingsmodel dat de EU Turkije zou kunnen voorhouden, ontbreekt dan ook (par. 2.3). 
Tegen deze achtergrond onderzoekt hoofdstuk 3 de kernvragen die relevant zijn voor de beoordeling van de Turkse islam en Turkije als moslimland, namelijk: hoe geworteld is de seculiere staat in Turkije en hoe verhouden de Turkse islam en de democratische rechtsstaat zich tot elkaar? Het hoofdstuk begint dan ook met een verkenning van de historische verankering van de seculiere staat (par. 3.2). De huidige positie van de Turkse islam in de Turkse democratische rechtsstaat wordt vervolgens belicht in aparte thematische paragrafen. Aan de orde komen de manier waarop de Turkse staat sinds de jaren vijftig is omgegaan met de opkomst van nadrukkelijk op islamitische grondslag gebaseerde politieke bewegingen (de politieke islam) (par. 3.3) en de wijze waarop de Turkse staatsislam zich verhoudt tot de vrijheid van godsdienst (par. 3.4). Voorts belicht het de relatie tussen democratie, mensenrechten en geweld enerzijds en politieke islam anderzijds (resp. par. 3.5, 3.6. en 3.7). Hoofdstuk 4 koppelt deze bevindingen terug naar de centrale vraag van het rapport en formuleert de eindconclusies.

Zoals vermeld is de thematiek van dit rapport mede ingegeven door de wereldwijd toegenomen betekenis van de politieke islam sinds de jaren zeventig. In dit verband rijst dan ook de vraag welke invloed een eventuele toetreding van Turkije zou kunnen hebben op de islamitische wereld. Hoewel deze vraag hier niet centraal staat, komt de WRR hier in de aparte 'Vooruitblik' wel op terug.

De WRR heeft prof. dr. E.J. Zürcher, hoogleraar Turkse talen en culturen, verzocht ten behoeve van dit Rapport een verkenning te verrichten van de boven geformuleerde centrale vraag, mede in het licht van de discussie over de botsing der beschavingen. Deze verkenning is samen met het raadsstandpunt in één band gepubliceerd.

\section{Tekstbox 1.1 Turkije en Europa: recente chronologie}

1948: Lidmaatschap van de OEES, voorloper van de Organisatie voor Europese Samenwerking en Ontwikkeling.

1949: Lidmaatschap van de Raad van Europa.

1952: Lidmaatschap van de Noord-Atlantische Verdragsorganisatie (NAVO).

1953: Ondertekening defensief Balkanpact met Griekenland en Joegoslavië.

1954: Ondertekenende partij bij het Europese verdrag tot bescherming van de rechten van de mens en de fundamentele vrijheden (EVRM).

1955: Ondertekening van het defensieve Bagdadpact met Irak. Pakistan, Engeland en Iran sluiten zich later aan.

1959: Gesprekken met de EEG over mogelijk lidmaatschap. 
1963: Ondertekening van de associatieovereenkomst met de EEG, die vooruitzicht biedt op lidmaatschap na zeventien jaar.

1975: Ondertekening van het Slotakkoord van Helsinki tot oprichting van de CVSE, voorloper van de in 1995 opgerichte Organisatie voor Veiligheid en Samenwerking in Europa (OVSE).

1987: EEG wijst aanvraag tot lidmaatschap af, maar biedt vooruitzicht op douane-unie met Turkije.

1995: Geassocieerd lid van de West-Europese Unie (WEI). Ondertekening (samen met elf andere mediterrane niet-lidstaten) van de Verklaring van Barcelona over het Euro-Mediterraan Partnerschap.

1996: Inwerkingtreding van de douane-unie met de EU.

1999: Status van kandidaat-lid toegekend door de EU tijdens de Europese Raad van Helsinki. De Raad concludeert dat voor Turkije dezelfde toetredingscriteria gelden als voor de andere kandidaat-lidstaten en dat het zal kunnen profiteren van de pretoetredingssteun ter ondersteuning van de hervormingen met het oog op lidmaatschap. De Europese Commissie start met de voorbereidingen voor een Partnerschap voor toetreding van Turkije.

2001: Aanname van het Partnerschap voor toetreding van Turkije en aanbieding door Turkije van het Nationale Programma voor de Overname van het Acquis aan de Europese Commissie, waarin de Turkse prioriteiten voor de korte en middellange termijn zijn vastgelegd met het oog op de toetreding.

2002: Europese Raad van Kopenhagen besluit tot lidmaatschap op 1 mei 2004 van acht van de tien kandidaat-lidstaten uit Midden- en Oost-Europa. Over Turkije luidt het oordeel 'dat als de Europese Raad in december 2004 besluit, op basis van een verslag en een aanbeveling van de Commissie, dat Turkije voldoet aan de politieke criteria van Kopenhagen, de Europese Unie onverwijld toetredingsonderhandelingen met Turkije zal aangaan.'

2004: Besluit verwacht in december over het al dan niet starten van de toetredingsonderhandelingen tijdens de Europese Raad onder Nederlands EU-voorzitterschap. 
De officiële standpunten van de Europese Toppen over de Turkse toetreding alsook in de voortgangsrapportages (regular reports) die door de Europese Commissie zijn en worden opgesteld over de vorderingen van Turkije ten aanzien van de Kopenhagen-criteria, noemen de islam niet. Dit is geen wonder want religie als zodanig maakt van de formele politieke criteria geen deel uit; deze hebben hoofdzakelijk betrekking op constitutionele en statelijke aspecten van de lidstaten. Medewerkers van de Europese Commissie antwoorden desgevraagd dan ook in de regel dat 'staatshoofden en regeringsleiders, het Europees Parlement, alle officiële instanties van de Europese Unie altijd benadrukken dat de Europese Unie is gebaseerd op gemeenschappelijke waarden en principes en niet op een specifieke cultuur of religie' (geciteerd in House of Commons 2001: 4). Een van de bekendste recentere uitspraken in die trant is afkomstig van Valérie Giscard d'Estaing, de voorzitter van de inmiddels afgesloten Europese Conventie voor het opstellen van de ontwerpgrondwet voor Europa (waaraan trouwens ook Turkije als waarnemer deelnam). Eind 2002 stelde hij dat tussen Turkije en Europa een onoverbrugbare culturele kloof bestaat, dat Turkije geen Europees land is en dat lidmaatschap ervan het einde van de EU zou inluiden. Hij voegde eraan toe dat vele Europese regeringsleiders dit standpunt zouden delen maar niet formeel durven uitspreken. Ook in kringen van de Europese Volkspartij (EVP) en de Duitse christen-democratische partijen CDU en CSU zijn deze bezwaren al eerder geuit en onlangs in het kader van de Conventie nog weer eens herhaald. De samenwerking binnen de EU, zo luidde het oordeel, berust op een stelsel van gemeenschappelijke christelijke waarden dat zich slecht verhoudt tot (Turkse) islamitische waarden. In de Nederlandse politiek wordt met name sinds begin 2004 gesproken over de religieuze factor als mogelijke belemmering voor Turkse toetreding. Terwijl het VvD-Kamerlid Van Baalen eind januari vaststelde dat het islamitische geloof van de Turken 'geen enkele rol' speelt in de bezwaren van zijn fractie tegen Turks lidmaatschap en premier Balkenende benadrukte de discussie hieromtrent niet te willen belasten met 'zaken als de islam', kwamen uit het kabinetsberaad ook andere signalen. De Nederlandse minister van Buitenlandse Zaken beschouwt toetreding van Turkije, mits dat land voldoet aan de gestelde Kopenhagen-criteria, echter als een handreiking aan de islamitische wereld ('Turkije niet aan het lijntje houden', Trouw 2 februari 2004). Het verslag van de Commissie buitenlandse zaken, mensenrechten, gemeenschappelijk veiligheid en defensiebeleid onder leiding van rapporteur Arie Oostlander dat in mei 2003 aan het Europees Parlement werd gepresenteerd, vestigde de aandacht op de positie van religieuze minderheden in Turkije. Europarlementariër Oostlander verwoordt zijn zorg als volgt: 'Ik moet als protestant in de Oost-Turkse stad Diyarbakir dezelfde rechten hebben als een moslim in Rotterdam. Als dat niet zo is en je laat Turkije toch toe tot de EU, beduvel je de kluit.' 'EU moet hard zijn voor Turkije', NRC Handelsblad, 11 februari 2004. Ook op de website van Oostlander: www.oostlander.net. 
De termen secularisme en seculier roepen veel verschillende associaties op, zoals ontkerkelijking, het verdwijnen van religie uit het publieke domein, een van bovenaf opgelegde verbanning van religieuze uitingen naar het privé-domein en de (institutionele) scheiding van geloofsgemeenschap (kerk) en staat. Dit rapport hanteert de term 'seculiere staat' om de autonome bevoegdheidsdomeinen van de staat en de geloofsgemeenschappen aan te duiden. Secularisatie wordt hier opgevat als een proces waarin de staat een grotere autonomie krijgt ten opzichte van de geloofsgemeenschappen.

5 Zie voor een dergelijke meer omvattende analyse bijvoorbeeld de studie van de Adviesraad voor Internationale Vraagstukken, Naar rustiger vaarwater, uit 1999 (AIV 1999). Medio 2004 verschijnt een geactualiseerd advies van de AIV. 


\section{$2.1 \quad$ INLEIDING}

Dit hoofdstuk verkent de voornaamste kenmerken van de EU en gaat na hoe de Unie en de lidstaten omgaan met religie. Het stelt vast dat de EU zich heeft ontwikkeld tot een waarden- en handelingsverbond dat berust op institutioneel verankerde politieke en burgerlijke basiswaarden van de democratische rechtsstaat die de autonomie van staat en kerk en de religieuze vrijheden en rechten garandeert (par. 2.2). Vervolgens geeft het een beknopt overzicht van de uiteenlopende wijzen waarop de lidstaten formeel en feitelijk gestalte geven aan die basiswaarden (par. 2.3).

Volgens de verdragsbepalingen (artikel 49, Verdrag van de Europese Unie, vEU) kan 'elke Europese staat' een verzoek indienen tot EU-lidmaatschap. Maar wat is 'Europees' en wat bindt de Europese staten? Deze vraag wordt steeds vaker gesteld nu het aantal (potentiële) lidstaten toeneemt en ook het takenpakket van de Unie steeds verder verbreedt (WRR 2003a). In zijn rapport Naar een Europabrede Unie concludeerde de WRR dat geografische en cultureel-historische benaderingen ter definiëring van Europa te weinig oog hebben voor het beweegbare en 'maakbare'. Europa kent immers een lange geschiedenis van fragmentatie, conflict en vooral schuivende politieke grenzen die op telkens uiteenlopende manieren werden gelegitimeerd. ${ }^{1}$ Daardoor is het geen vast gegeven maar een dynamische sociale constructie, een imagined community die onder invloed van de omstandigheden en door politiek leiderschap kan veranderen (WRR 2001: 3236). Ook de ontwikkelingen in de twintigste eeuw onderstrepen dit. In de jaren vijftig en zestig beschouwden de toenmalige politieke leiders van het 'Europa van de Zes' hun ervaring met verwoestende oorlogen en genocide als het fundament voor gezamenlijk economisch optreden. Sinds het einde van de Koude Oorlog heeft het doel van het overbruggen van nationale tegenstellingen en consolideren van vrede, democratie en welvaart bepaald niet aan relevantie ingeboet. Maar door het vooruitzicht van een EU van 25 lidstaten staat Europa niet langer in het bewustzijn gegrift als 'West-Europa'. De meeste EU-lidstaten en de Europese Commissie hebben zich dan ook onthouden van statische cultureelreligieuze, historische of geografische definities van de Unie. Ze erkennen dat een zekere lotsverbondenheid en geografische beperking essentieel is om gezamenlijk te kunnen optrekken, maar zonder hieraan een blauwdruk met geografische grenzen of exclusieve, niet-universele waarden te willen verbinden.

In het besef dat fundamentele principes en doelstellingen houvast én flexibiliteit bieden, typeert de EU zichzelf als een waarden- en handelingsverbond (WRR 2001: 36). Essentieel is dat (aankomende) lidstaten de fundamentele principes, normen, regels en procedures van de Unie onderschrijven (het waardenverbond) 
en tevens bereid en in staat zijn de concrete doelen van de Unie na te streven (het handelingsverbond). In de bejegening van kandidaat-lidstaten vertaalt zich dit in een rechten-en-plichtenbenadering waarin politiek-burgerlijke principes en waarden van de Unie vooropstaan als noodzakelijke voorwaarden voor toetreding. Alleen als deze landen daaraan voldoen, kunnen ze een toetredingsverzoek indienen. In het Verdrag van Maastricht (dat in november 1993 in werking trad) en Amsterdam (1 mei 1999) zijn deze principes en waarden uitvoerig gecodificeerd. Artikel 6, lid 1, EU, stelt:

“De Unie is gegrondvest op de beginselen van vrijheid, democratie, eerbiediging van de rechten van de mens en de fundamentele vrijheden, en van de rechtsstaat, welke beginselen de lidstaten gemeen hebben."

De Europese Conventie over de toekomst van Europa (2002-2003) luidde een verdere bezinning in op de normatieve grondslagen en uitgangspunten van de Unie, mede om het Europese project dichter bij de burger te brengen. Het 'ontwerp-Verdrag tot vaststelling van een Grondwet voor Europa' waarover de Conventieleden het midden 2003 eens werden, onderstreept het belang van het waardenverbond. In de preambule staat dat:

"Europa als werelddeel een bakermat van de beschaving is; dat zijn inwoners, die zich hier sedert mensenheugenis golfsgewijs gevestigd hebben, geleidelijk de waarden hebben ontwikkeld die ten grondslag liggen aan het humanisme: gelijkheid van alle mensen, vrijheid en eerbied voor de rede,

Geïnspireerd door de culturele, religieuze en humanistische tradities van Europa, waarvan de waarden, die immer deel hebben uitgemaakt van zijn erfgoed, de centrale rol van de mens en zijn onschendbare en onvervreemdbare rechten, alsmede de eerbiediging van het recht, in de samenleving hebben verankerd" (Europese Conventie 2003: 5).

Artikel 2 van het ontwerp-Verdrag, getiteld 'De waarden van de Unie' stelt bovendien:

"De waarden waarop de Unie berust, zijn eerbied voor de menselijke waardigheid, vrijheid, democratie, gelijkheid, de rechtsstaat en eerbiediging van de mensenrechten. Deze waarden hebben de lidstaten gemeen in een samenleving die gekenmerkt wordt door pluralisme, verdraagzaamheid, rechtvaardigheid, solidariteit en het verbod op discriminatie" (Europese Conventie 2003: 9).

De verwijzing naar religie in de preambule is de uitkomst van een debat over de vraag of het christendom expliciete vermelding verdient. In plaats van zoals nu te spreken van de "culturele, religieuze en humanistische tradities van Europa" als inspiratiebron zou dan volgens sommigen een explicietere verwijzing moeten komen naar de 'judeo-christelijke traditie'. Anderen gaan nog verder door de 
huidige EU te willen bestempelen als een 'christelijke waardengemeenschap'. Daarmee kunnen ze Turkije al bij voorbaat uitsluiten van lidmaatschap. De meeste actoren in dit debat zijn zich er echter van bewust dat deze invulling problematisch is in het licht van de Conventiediscussie. Het zou immers vreemd zijn als de lidstaten van de op universele waarden gebaseerde Unie zich zouden beroepen op hun 'christelijke waarden' om een land het lidmaatschap te ontzeggen. Bovendien zou het ook strijdig zijn met hun pleidooi het (religieuze) pluralisme en de diversiteit te koesteren (artikel 2 van de ontwerpgrondwet) en met het EU-streven historische tegenstellingen te overbruggen.

Van de waarden waarop de Unie blijkens de Verdragen en de ontwerp-grondwet berust, maken religieuze waarden dan ook geen deel uit. Het hierboven geciteerde artikel 6 , lid 1 spreekt van de 'beginselen van vrijheid, democratie, eerbiediging van de rechten van de mens en de fundamentele vrijheden, en van de rechtsstaat'. Religie komt uiteraard wel voor in het Handvest van grondrechten van de EU. Artikel II-10-1 regelt de vrijheid van gedachte, geweten en godsdienst en artikel II-21-1 verbiedt discriminatie op grond van onder meer godsdienst of overtuiging. Daarnaast stelt artikel II-22 dat de Unie de verscheidenheid van cultuur, godsdienst en taal respecteert. Bij deze artikelen gaat het dus om positief Unierecht, maar er wordt geen wissel getrokken op een normatieve basis die verdergaat dan de genoemde minimumwaarden en grondrechten.

Het definiëren van de EU als een politiek-burgerlijk waarden- en handelingsverbond dat berust op "de beginselen van vrijheid, democratie, eerbiediging van de rechten van de mens en de fundamentele vrijheden, en van de rechtsstaat" voorkomt dus dat culturele, religieuze of historische kenmerken of waarden al bij voorbaat worden ingezet om potentiële lidstaten uit te sluiten. De consensus over deze waarden impliceert echter niet dat uitsluiting, verdeeldheid of conflicten te allen tijde zijn te voorkomen. Juist in concrete situaties zullen altijd conflicten en spanningen ontstaan over de hiërarchie of toepassing van waarden (WRR 2003b: 47-53). Dan gaat het immers om een specifiekere beoordeling van wat wordt gewaardeerd, in welke context en relatie tot andere waarden, door en voor wie of wat. Dat geldt voor het verkeer tussen individuen, groepen én lidstaten. Illustratief is het 'waardenconflict' tussen Oostenrijk en de overige 14 EUlidstaten dat in 2000 ontstond na de verkiezingsoverwinning van de FPÖ onder leiding van Jörg Haider, die zich uitgesproken negatief had uitgelaten over immigranten. Toen de ÖvP in januari van dat jaar coalitieonderhandelingen startte met de FPÖ, dreigden 'de 14' met sancties tegen Oostenrijk als de FPÖ daadwerkelijk in de regering zou komen. Ze wilden daarmee druk uitoefenen op Oostenrijk om de FPÖ buiten de regering te houden, naar eigen zeggen ter bescherming van de gemeenschappelijke waarden van de Unie zoals verwoord in artikel 6, lid 1. Deze actie leidde echter tot een diepe crisis in de relaties tussen Oostenrijk en de EU. Noch de EU noch één of meer lidstaten had zich immers ooit eerder zo openlijk gemengd in het democratische proces van een nationale lidstaat. Bovendien beriepen de 14 zich op de waarden genoemd in artikel 6, maar konden ze geen sancties uitvaardigen namens de EU, want die had uiteraard nog geen concrete 
schending kunnen constateren. Toen de FPÖ inderdaad in de regering plaatsnam, gingen de 14 gezamenlijk over tot bilaterale sancties. Oostenrijk dreigde op zijn beurt het EU-besluitvormingsproces zoveel mogelijk te blokkeren en een referendum uit te vaardigen over de sancties. De patstelling kon uiteindelijk pas worden doorbroken doordat het EU-voorzitterschap namens de 14 een Commissie van Wijzen liet rapporteren over de verhouding van de nieuwe Oostenrijkse regering tot de Europese waarden. Het rapport verklaarde dat het Oostenrijkse immigratiebeleid strookte met de waarden van de Unie en dat handhaving van de sancties wel eens averechtse effecten zou kunnen hebben.

De casus Oostenrijk onderstreept ten eerste dat het onderschrijven van waarden, zelfs in de vorm van algemene rechtsbeginselen, geen neutrale recepten oplevert voor concreet handelen en waardenconflicten niet uitsluit. Maar de casus laat ook zien dat waardenconflicten via procedures en spelregels kunnen worden opgelost. Deze les, die de pragmatische Eu uiteraard allang kende, heeft de lidstaten er mede toe aangespoord in het Verdrag van Nice (1 februari 2003) een gewijzigd artikel 7 op te nemen. Dit biedt een flexibelere maar tegelijkertijd meer afwachtende procedure waarmee de EU een "duidelijk gevaar voor een ernstige schending van in artikel 6, lid 1, genoemde beginselen door een lidstaat" kan aanpakken. ${ }^{2}$ Artikel 7 heeft inmiddels zijn waarde bewezen. Hoewel het aantreden in 2001 van de Italiaanse regeringscoalitie van Forza Italia, de Alleanza Nazionale en de Lega Nord opnieuw aanleiding was tot zorgen in de EU, wisten de regeringsleiders zich ditmaal gesteund door de nieuwe spelregels. Daarmee daalde de kans op ondoordachte acties of politieke crises, zonder de actieve peer group pressure op het spel te zetten die op EU-niveau mede bijdraagt aan de bescherming van de fundamentele waarden. ${ }^{3}$ Ten slotte illustreert de casus Oostenrijk dat, naarmate de lidstaten met een beroep op gemeenschappelijke waarden hogere eisen stellen aan elkaars democratische rechtsstaten én de onderlinge diversiteit binnen de EU stijgt door nieuwe toetredingsronden, aanvullende spelregels en mechanismen nodig zijn voor de omgang met antidemocratische tendensen.

\subsection{RELIGIE IN DE EUROPESE LIDSTATEN}

\subsubsection{WEDERZIJDSE AUTONOMIE EN BORGING VAN VRIJHEDEN}

Doordat de Europese Commissie via het politieke Kopenhagen-criterium de democratische rechtsstaat in Turkije de maat neemt, confronteert ze de huidige lidstaten indirect met vragen en problemen die tot dusver veelal buiten het 'normale' Europese politieke discours en publieke debat vielen. Het betreft vragen als: wat behoort de plaats te zijn van religie in de samenleving? Hoe moeten staat en religie zich tot elkaar verhouden?

Het is duidelijk dat huidige en aankomende Europese lidstaten moeten beschikken over een democratische rechtsstaat die tegemoetkomt aan de erkenning en borging van de autonomie van staat en geloofsgemeenschap en de vrijheid van 
godsdienst en geweten. ${ }^{4}$ Het principe dat staat en geloofsgemeenschappen (waaronder ook kerken) elkaars autonomie respecteren, is hetzij vastgelegd in nationale grondwetten, in zogenoemde concordaten of overeenkomsten tussen de staat en de religieuze denominaties, dan wel verankerd via de jurisprudentie van nationale Constitutionele Hoven. Het uitgangspunt van de autonomie impliceert dat staat en kerk elk aparte bevoegdheidssferen hebben. Exclusieve staatsbevoegdheden moeten zijn gevrijwaard van directe zeggenschap door kerken en geloofsgemeenschappen. Omgekeerd heeft de staat geen directe bevoegdheden over de interne aangelegenheden van kerken en geloofsgemeenschappen. Dit laat onverlet dat de staat wel van religieuze gemeenschappen mag verlangen dat ze zich houden aan de grondslagen van de wet. Het grondrecht van de vrijheid van godsdienst en geweten impliceert dat gelovigen van minderheidsreligies, atheïsten en geloofsafvalligen geen beperkingen ontmoeten in hun politieke en burgerrechten vanwege hun (geloofs)overtuigingen. Hieruit vloeien zowel individuele als collectieve rechtsdimensies voort. De rechtsstaat dient het individu te beschermen tegen (groeps)dwang. Het individu mag echter niet met een beroep op zijn (geloofs)overtuiging of verbintenis aan een geloofsgemeenschap de beginselen van de rechtsstaat schenden. De rechtsstaat dient daarnaast ook invulling te geven aan het recht op collectieve geloofsbeleving. Hoewel deze rechten ook onderdeel uitmaken van de vrijheid van vereniging en vergadering en de vrijheid van meningsuiting, is het van belang dat deze collectieve rechten in Europese rechtsstaten in principe openstaan voor elke religieuze groep (Ferrari 2002: 8). Hieruit vloeit ook het principe voort van de neutraliteit van de staat tegenover de religie: de staat mag niet één levensbeschouwelijke visie bevoordelen ten opzichte van andere. Het politieke proces, bijvoorbeeld, moet in gelijke mate openstaan voor mensen van alle gezindten. In tegenstelling tot wat vaak wordt gedacht, betekent het dus niet dat geloof en politiek moeten worden gescheiden (Bielefeldt 2000:6; Rouvoet 2003).

In het geval van kandidaat-lidstaat Turkije stelt de Europese Commissie vooral de tekortschietende rechten op religieus terrein aan de kaak. In de voortgangsrapportage van 2003 concludeert ze onder meer:

"Concerning freedom of religion, the changes introduced by the reform packages have not yet produced the desired effects. Executive bodies continue to adopt a very restrictive interpretation of the relevant provisions, so that religious freedom is subject to serious limitations as compared with European standards. This is particularly the case for the absence of legal personality, education and training of ecclesiastic personnel as well as full enjoyment of property rights of religious communities" (Europese Commissie 2003).

Hoewel deze 'Europese standaarden' kunnen worden opgevat als een verwijzing naar de principes van de vrijheid van godsdienst uit het EVRM, bestaat in de praktijk geen eenduidigheid onder de lidstaten over de manier waarop die vrijheid en autonomie tegenover de staat concrete invulling verdienen. Zoals hieronder zal blijken, is hiervoor de diversiteit aan nationale arrangementen en de 
feitelijke bevoordeling van traditionele religieuze gemeenschappen binnen de lidstaten te groot. Bovendien ligt ook de verhouding van religie en kerk tegenover staat en samenleving in veel lidstaten erg gevoelig (zie ook tekstbox 2.1). De Europese Commissie beperkt zich dan ook tot het toetsen aan de minimumvoorwaarden.

\subsubsection{EEN EUROPEES MODEL?}

Om de feitelijke rol van religie in staat en samenleving te begrijpen, is het nodig verder te kijken dan deze in de praktijk toch al moeilijk te meten minimumvoorwaarden. Evenmin kan worden volstaan met het hanteren van eenvoudige tweedelingen zoals wel of geen staatskerk, wel of geen religieus pluralisme en wel of geen subsidies aan kerkgenootschappen. Dat wordt nog duidelijker als we niet uitsluitend kijken naar de constitutionele en juridisch vastgelegde verhoudingen, maar ook naar de bestuurlijke, politiek-maatschappelijke en culturele situatie. Zoals hieronder zal worden betoogd, sluiten deze uit dat er één ideaal ontwikkelingstraject zou bestaan waaraan de moderniteit van de Turkse staat en de Turkse islam kan worden afgemeten.

De institutionele autonomie van staat en religie in de huidige Europese landen is de uitkomst geweest van de Reformatie, processen van staatsvorming, de groei van het moderne kapitalisme en de moderne wetenschappelijke revolutie (Bader 2003b: 57). De manier waarop deze processen elkaar versterkten, verschilde naar tijd en plaats en zorgde voor uiteenlopende padafhankelijkheden. Invloedrijk waren met name het wel of niet slagen van de Reformatie, die bepalend werd voor de scheiding tussen protestantse en katholiek/orthodoxe landen in Europa; de mate waarin de Reformatie en de daaropvolgende opstanden leidden tot interne verdeeldheid (Frankrijk, België) of juist tot eenheid tegen een externe vijand (Nederland tegen Spanje; Ierland en de vs tegen Engeland) en ook het wel of niet aanwezig zijn van een strijdbare verlichtingskritiek op de religie (Frankrijk en Engeland wel, Italië, Ierland en Spanje niet) (zie ook tekstbox 2.1). ${ }^{5}$

Uit deze verschillende ontwikkelingstrajecten zijn enkele algemene conclusies te trekken over de evolutie van de banden tussen staat, kerk, religie, politiek en maatschappij. Ten eerste blijkt dat de Europese staten weliswaar een grote mate van feitelijke autonomie van staat en kerk kennen, maar lang niet allemaal elke formele constitutionele band met de kerk hebben verbroken. Alleen Nederland, Frankrijk en de meeste Midden- en Oost-Europese landen (veelal tot de val van het communisme) zijn te classificeren als staten die de constitutionele banden tussen de dominante religie of kerk en de staat hebben verbroken ('disestablishment'). ${ }^{6}$ Engeland kent een staatskerk onder de formele leiding van het staatshoofd. De premier benoemt via het staatshoofd zowel het hoofd van de kerk (de aartsbisschop van Canterbury) als de hogere rangen in de Church of England. Voor 26 senior bisschoppen is een plaats gereserveerd als Lord Spiritual in het Hogerhuis, terwijl 6 van de 33 bestuurders die belast zijn met het beheer van het kerkeigendom, overheidsambtenaar zijn. Al deze bestuurders (onder wie 
ambtshalve ook de premier en de minister van sport en cultuur) zijn verantwoording schuldig aan het parlement en de Algemene Synode van de Church of England. ${ }^{7}$

Landen als Schotland, Noorwegen en Denemarken, Duitsland en Zwitserland hebben in de loop van de tijd hun stelsel van sterke staatsdominantie over de kerk vervangen door een zwakkere constitutionele band, zonder een staatskerk volledig af te zweren. Desondanks kan van deze landen niet worden gezegd dat ze minder democratisch of modern zouden zijn. Ten tweede betekent de afwezigheid van een staatskerk niet een volledige scheiding van kerk en staat. In de meeste landen die de staatskerk uiteindelijk afschaften of geen formele staatskerk hadden, was (of is) sprake van de feitelijke politieke en culturele dominantie van één kerkgenootschap. Daardoor is de wederzijdse politieke en culturele beïnvloeding van religie, staat en maatschappij veelal blijven voortbestaan (Bader 2003b: 59-61). In landen als Polen, Griekenland, Ierland, Bulgarije, Roemenië en Armenië bijvoorbeeld is de band tussen staat, natie en kerkgenootschap zelfs bijzonder hecht. In die laatste drie landen gaf de onafhankelijkheidsstrijd tegen de Osmaanse en Turkse moslims extra gewicht aan de etnische betekenis van de religie.

\section{Tekstbox 2.1 Christendom, kerk, staat en natie in Europa}

\section{Strijd en schisma's}

De dominante en langdurige aanwezigheid van het christendom in Europa is nog altijd duidelijk zichtbaar. De christelijke religie is echter bepaald niet steeds een bindende, integrerende en gemeenschapsvormende factor (geweest). De geschiedenis van het Europese christendom is diep getekend door conflicten tussen sektarische groepen en stromingen (ofwel groepen zonder een formele kerk en/of hiërarchie) en gevestigde kerken waaronder met name de rooms-katholieke, protestantse en orthodoxe kerken. Deze drie grote kerken ontwikkelden uiteindelijk elk hun eigen (legitimerende) banden met het wereldlijk gezag. Parallel daaraan voltrok zich een lange strijd tussen het machtscentrum van de staat en dat van de kerk. Vanaf ongeveer de vierde tot de negentiende eeuw neigden alle vertegenwoordigers van het seculiere staatsgezag ertoe direct of indirect steun te verlenen aan een stelsel waarin één ('de ware') versie van het christendom het religieuze monopolie had. Religieuze uniformiteit en conformisme, zeker indien samenvallend met het territoriale gezag van de staat, werden geacht het belang van staat en onderdanen te dienen én de interne orde en stabiliteit te versterken. Daarin ontving de staat steun en legitimering van de gevestigde religieuze autoriteiten, die evenzeer gebaat waren bij de eenheid van de religieuze leer en geloofsgemeenschap. Dit uitte zich niet alleen in op religieuze principes gebaseerde wetgeving, maar ook in de institutionele verstrengeling van religie en staat (Sunier 2004). Eenmaal geconfronteerd met religieuze verdeeldheid onder de bevolking (door religieuze afsplitsingen, territoriale verschuivingen, migratie enz.), was de gebruikelijke reactie van staat en kerk gedurende de vroegmoderne periode het onderdrukken van door de kerk als 'ketterij' gedefinieerde concurrerende geloofsinterpretaties, het partij kiezen tegen de gevestigde religieuze kerkorde en vóór de afwijkende religieuze gemeenschap of het 'gedogen' van afwijkende interpretaties of religies. Volledige religieuze tolerantie, neutraliteit of volledige onderdrukking kwamen tot de negentiende eeuw 
maar zelden voor, mede door de diepgewortelde vrees voor opstanden en burgeroorlogen die de Reformatie had achtergelaten. Opvallend is dat de huidige multiconfessionele staten in Europa in de praktijk al deze strategieën althans op onderdelen hanteren, óók waar het elementen van onderdrukking betreft (zoals in het geval van radicale sektarische groepen die als (staats)gevaarlijk te boek staan). De erfenis van conflicten tussen kerken en sektarische groepen en de afwisselende strijd en het samenspel tussen staat, kerk en natie is mede debet aan de gevoeligheid van de thematiek van de betrekkingen tussen kerk en staat in veel Europese landen.

De erfenis van kerkscheidingen die Europa verdelen in Noord en Zuid en Oost en West is ook in het herenigde Europa van na 1990 zichtbaar. De World Christian Encyclopedia (2001) onderscheidt cultuurgebieden met zones waar (combinaties van) rooms-katholieke, anglicaanse, calvinistische, protestantse, lutherse, orthodoxe, Armeense en moslimgemeenschappen wonen. De monoconfessionele cultuurzones, waartoe het lutherse noorden, het rooms-katholieke zuiden en het orthodoxe oosten worden gerekend, beslaan ruim 406 miljoen van de ongeveer 681 miljoen Europeanen (Madeley 2003).

\section{Classificaties}

Er zijn tal van classificaties in omloop ter typering van de relatie tussen religie en staat in de verschillende Europese landen. In navolging van onder anderen Barrett e.a. hanteert Madeley (2003) op basis van formele juridische criteria én de feitelijke banden een driedeling: staten die (één) religie of religieuze instellingen bevorderen ('religieus'), staten die religie bevorderen noch ontmoedigen ('seculier') en staten die 'atheïstisch' zijn. Langs deze driedeling vielen in 1980 van de in totaal 35 Europese staten niet minder dan 22 in de eerste groep (het Vaticaan, België, Denemarken, Finland, West-Duitsland, Griekenland, IJsland, Liechtenstein, Luxemburg, Monaco, Noorwegen, Spanje, Zweden, Zwitserland, Andorra, Portugal, Engeland, Schotland, Italië, Malta, Ierland en Cyprus. Slechts vijf staten vielen in de tweede, seculiere groep (nl. Oostenrijk, Nederland, San Marino, Frankrijk en Turkije) en negen in de groep 'atheïstisch' (nl. Joegoslavië, de DDR, Bulgarije, Hongarije, Roemenië, Polen, Tsjecho-Slowakije, de UssR en Albanië). Maar zelfs de meeste toenmalige communistische staten kenden een speciale status toe aan specifieke religieuze tradities, vooral als die historisch nauw verbonden werden geacht aan de nationale staat. In Bulgarije, bijvoorbeeld, bleef ook onder het communisme een wet bestaan die verklaarde: 'The Bulgarian Orthodox Church is the traditional faith of the Bulgarian people. It is bound up with their history and, as such, its nature and its spirit can be considered a church of the popular democracy.' (Madeley 2003). Tegelijkertijd hielden de staat en de communistische partij religieuze activiteiten en instellingen nauwgezet in de gaten.

Een vergelijkbare classificatie van betrekkingen tussen kerk en staat voor het jaar 2000 (voor een totaal van dan inmiddels 48 Europese staten) komt uit op 30 staten in de eerste groep, een forse stijging die vooral is te verklaren door de 'overstap' van voormalige communistische landen en net zelfstandig geworden staten uit Midden- en Oost-Europa van de groep van 'atheïstische' staten naar de twee andere groepen. De groep 'seculier' stijgt hierdoor naar 17 lidstaten en de groep 'atheïstisch' verdwijnt volledig. Opmerkelijk is ook dat de staatscontrole over de religie in deze staten is ontmanteld en in de meeste gevallen zelfs heeft plaatsgemaakt voor staatssteun, hetzij in de vorm van het financieren van de (her)bouw van kerken, hetzij in de vorm van het beschikbaar stellen van nationale belastingen aan erkende religieuze genootschappen. 


\section{Geloofsgemeenschappen, subsidiariteit en EU-besluitvorming}

De toenemende betekenis van de EU-regelgeving lokt ook steeds meer levensbeschouwelijke bewegingen zoals kerkgenootschappen en humanistische organisaties naar de Brusselse politieke arena. Dit leidt tot bekende patronen van 'europeanisering' en onderlinge concurrentie (WRR 2003a): enerzijds proberen veel kerkelijke instellingen het specifieke nationale kerk-staatmodel van hun staat veilig te stellen tegenover Europese regelgeving, en anderzijds zoeken ze naar formele en informele wegen om hun eigen, geprefereerde (nationale) model te exporteren naar het Europese niveau, of op dat niveau de eigen lobby te laten doorklinken.

In formele zin hebben de Europese instellingen geen directe bemoeienis met de betrekkingen tussen kerk en staat in de lidstaten, aangezien hiervoor het zogenoemde subsidiariteitsprincipe geldt. Dit werd al vastgelegd in de aparte (juridisch niet-bindende) Verklaring nr. 11 bij het Verdrag van Amsterdam, die luidt: "De Europese Unie eerbiedigt en doet geen afbreuk aan de status die de kerken en religieuze verenigingen en gemeenschappen volgens het nationale recht in de lidstaten hebben. De Europese Unie eerbiedigt evenzeer de status van levensbeschouwelijke en niet-confessionele organisaties" (Europocket 2002: 227). Tijdens de voorbereidende besprekingen voor het Verdrag deed een commissie van deskundigen van de Bisschoppenconferentie van de EU (COMECE) en de Commissie Kerk en Samenleving van de Raad van Europese Kerken (CEC) eveneens, maar tevergeefs, pogingen te laten opnemen dat het specifieke model van betrekkingen tussen kerk en staat van elke lidstaat onderdeel vormt van 'de eigen identiteit.' Het lukte echter wel Verklaring 11 te laten opnemen in artikel 51 van de ontwerpgrondwet voor Europa. Bovendien werd daaraan nog toegevoegd de bepaling uit lid 3: “De Unie voert een open, transparante en regelmatige dialoog met die kerken en organisaties, onder erkenning van hun identiteit en specifieke bijdrage" (Europese Conventie 2003: 45).

Informeel timmeren vooral die religieuze gemeenschappen aan de weg die gebruikmaken van zogenoemde concordaten (waarin speciale rechten, sociale rollen enz. zijn vastgelegd), die tot de staatskerken behoren of al langer in de lidstaten zijn erkend. De al genoemde CEC en COMECE, bijvoorbeeld, worden uitgenodigd voor tripartite overleg met de Europese Raad, voorafgaand aan het halfjaarlijkse nieuwe Europese voorzitterschap. Mede hierdoor, en ook dankzij hun eigen medewerkers in Brussel en de informatie van invloedrijke concordaatlanden als Duitsland, hebben ze een informatie- en middelenvoorsprong op andere (geloofs)overtuigingen, zoals de islam en het humanisme. De Europese Humanistische Federatie probeert de laatste jaren actiever te lobbyen en heeft inmiddels ook enkele medewerkers, terwijl de Russische orthodoxe kerk, en de Oekraïense katholieke kerk in 2002 resp. 2003 een kantoor in Brussel openden. Behalve via de Europese Raad en de lidstaten is er ook een informele, veel pluralistischer 'gestructureerde' dialoog met de Europese Commissie en een halfjaarlijks overleg met de Forward Studies Unit, de denktank van de voorzitter van de Commissie. Deze dialoog geeft meer ruimte aan andere denominaties en groepen, waaronder ook moslims, protestantse minderheidsgroepen, boeddhisten, hindoes, aanhangers van Scientology, enz. (Massignon 2003).

Ondanks de vele specifieke, historisch gegroeide arrangementen hebben godsdienstsociologen typologieën ontwikkeld van institutionele en beleidsarrangementen waarmee de ontwikkeling van de relaties tussen religie, staat en maatschappij beter kan worden geplaatst en begrepen. In navolging van Bader wordt 
hier een typologie onderscheiden langs vier dimensies van staatsbemoeienis met de religie:

I de constitutionele, juridische, bestuurlijke, politieke en culturele banden tussen staat en religie;

2 de doelstellingen van de staat ten aanzien van de religie;

3 de uiteenlopende machten (wetgevend, rechtsprekend en uitvoerend) en bestuurlijke niveaus (federaal, statelijk, lokaal);

4 het beleid op andere dan direct aan de religie gerelateerde terreinen (Bader 2003b: 61-64).

De constitutionele banden betreffen de regels over religieuze vrijheden en de mate waarin sprake is van een gevestigde staatskerk met constitutioneel vastgelegde taken van de staat tegenover de kerk. Te denken valt aan het benoemen of erkennen van voorgedragen kerkleiders, het financieren van de salarissen van het kerkpersoneel of het innen van belastingen ten behoeve van de kerk. De juridische en bestuurlijke banden variëren van algemeen en vrij beperkt tot zeer specifiek en uitvoerig, mede afhankelijk van welke doelen de staat heeft ten opzichte van één of meer godsdiensten. Staten kunnen in principe (bepaalde) religies onderdrukken, gedogen, beschermen of actief bevorderen en daartoe allerlei instrumenten inzetten (zie tekstbox 2.1). De meeste Europese staten bieden bijvoorbeeld juridische en bestuurlijke uitzonderingsposities, zoals het recht op weigering van militaire dienst of het recht te discrimineren tegen vrouwen en homoseksuelen op basis van geloofsovertuiging, uitzonderingen op de zondagssluiting en de bouwvoorschriften, enz. Ze kennen vaak ook specifieke privileges toe, zoals subsidies aan religieuze organisaties, groepen en scholen. Kortom, staten gaan verschillend om met religieuze vrijheden, waardoor allerlei uiteenlopende balansen ontstaan tussen de concurrerende belangen van individuele en collectieve religieuze autonomie, vrijheid en antidiscriminatie. Door ontwikkelingen als immigratie, ontkerkelijking, individualisering en de opkomst van nieuwe denominaties worden vele lidstaten echter pluralistischer. Dat noopt ze tot het vinden van nieuwe arrangementen tussen staat, maatschappij en religieuze (minderheids)groepen.

De formele grondwettelijke of juridische erkenning van een bepaalde religie of religieuze gemeenschap door de staat garandeert niet dat de geloofsgenoten zich ook feitelijk kunnen vestigen; soms stuiten ze op - lokale - bestuurlijke of politieke obstakels. In België bijvoorbeeld werd de islamitische eredienst al in 1974 formeel erkend. Een Koninklijk Besluit riep op “... tot inrichting van de (provinciale) comités belast met het beheer van de temporaliën van de erkende islamitische gemeenschappen" (Waardenburg 2001: 48). Doordat deze comités nooit van de grond zijn gekomen en moslims zelf de representativiteit van het door de staat erkende landelijk orgaan van moslims in België lange tijd betwistten, volgde pas in 1998 feitelijke erkenning via verplichte overheidsfinanciering van de eredienst. Omgekeerd hoeft het ontbreken van formele constitutionele of juridische erkenning niet altijd een feitelijke belemmering te zijn voor institutionele, politieke of culturele ontplooiing. In Nederland bijvoorbeeld zijn ook na de 
grondswetswijziging van 1983, die formeel de financiële banden verbrak tussen staat en kerk, in het kader van het integratiebeleid allerlei regelingen totstandgekomen voor subsidiëring van gebedsruimten en zorg voor moslims. Dit gebeurt echter onder de pragmatische vlag van sociaal-culturele activiteiten, aangezien religieuze activiteiten formeel niet kunnen worden gesubsidieerd (Waardenburg 2001: 30; Sunier 2004). Uitzondering hierop vormt uiteraard het in artikel 23 van de grondwet gegarandeerde recht op bijzonder onderwijs. Dit erkent de overheidsfinanciering van onder meer op godsdienstige grondslag gebaseerd onderwijs. Engeland kent zelfs geen juridisch statuut waardoor andere kerken dan de Church of England formele erkenning of subsidies kunnen verwerven. Maar sinds de jaren tachtig is wel een groot aantal islamitische gebedsruimtes geregistreerd als liefdadigheidsinstelling (charity) waardoor ze in aanmerking komen voor speciale belastingvoordelen. Daarnaast biedt het land ook ruimte aan talloze islamitische sociaal-culturele instellingen en festivals. Met de oprichting van islamitische scholen in Engeland is het echter weer veel lastiger gesteld, aangezien daartegen op lokaal niveau veel politiek verzet bestaat (Waardenburg 2001: 63-69).

Ook in Duitsland stuit de institutionalisering van andere godsdiensten soms op problemen. In principe waardeert de staat kerken positief, maar probeert hij strikte neutraliteit te betrachten tegenover de verschillende geloven. Kerkgenootschappen met een publiekrechtelijke status en een permanent karakter kunnen gebruikmaken van de grondwettelijk verankerde mogelijkheid de staat een kerkbelasting te laten heffen. Bovendien kan de staat kerken subsidiëren om sociale en culturele functies te vervullen. Pogingen van moslimorganisaties om die publiekrechterlijke erkenning te krijgen, stuiten echter op grote problemen. Behalve dat net als in Nederland en België de representativiteit van deze organisaties moeilijk is aan te tonen, kampen moslimorganisaties ook met formeel beargumenteerde politieke tegenstand. Sommige Duitse overheden ontkennen het permanente karakter van deze organisaties (onder het motto: moslims zijn als immigranten tijdelijk aanwezig). Daarnaast stellen politieke tegenstanders dat de islam onder andere door discriminatie van vrouwen ongrondwettig is, zodat formele erkenning niet kan worden verleend (Waardenburg 2001: 54-62). Zelfs als de centrale overheid zoveel mogelijk formele en feitelijke neutraliteit probeert te betrachten, zullen beslissingen over privileges, subsidies, belastingen, bouwvergunningen, enz. dus indirect meestal ook de politieke arena en het politieke debat beïnvloeden.

Aan de hand van de eerder vermelde vier dimensies en de mate van religieus pluralisme blijkt het laïcistische Frankrijk het meest te voldoen aan de zuivere scheidingsdoctrine. ${ }^{8}$ Zoals in hoofdstuk 3 duidelijk zal worden, zijn er naast verschillen ook interessante overeenkomsten tussen het Turkse en het Franse laïcisme. Dit laatste vertoont duidelijke sporen van langdurige en hevige conflicten van de Franse staat met zijn religieuze gemeenschappen. Vanaf de Middeleeuwen kregen de joden te maken met pogroms en verbanningen, de protestanten werden in de zestiende en zeventiende eeuw vervolgd en verdreven (de 
St.Bartholomeusnacht resp. het Edict van Nantes) en de katholieken werden na de Franse Revolutie als 'erfvijand van de Verlichting' zwaar vervolgd. Bij de wet op de congregaties (1903) werden geloofsgemeenschappen vervolgens alleen erkend na aanvraag van een verplichte vergunning, die door het Franse parlement moest worden goedgekeurd. De jezuïetenorde bijvoorbeeld weigerde dit, met als argument dat God en niet het Franse parlement het hoogste gezag vormt. Daardoor gaven de jezuïeten decennialang geen eigen onderwijs meer in Frankrijk. Sinds 1905 bestaat de juridische, bestuurlijke, politieke en culturele scheiding van kerk en staat en betracht de staat strikte neutraliteit. Religieus pluralisme behoort formeel alleen toe aan de privé-sfeer en het burgerlijke domein van de civil society, niet aan de staat. Deze laatste garandeert de vrijheid van godsdienst en geweten en de vrije uitoefening van de eredienst, formeel zonder erediensten te erkennen, bekostigen of subsidiëren. Er is ook formeel een controlerende rol weggelegd voor de premier, die (behalve in Elzas-Lotharingen) het recht heeft op het aanwijzen van kardinalen en bisschoppen, zij het met een benoemingsrecht van het Vaticaan (Le Goff \& Rémond 1992). Tegelijkertijd ontkomt ook Frankrijk al decennialang niet aan feitelijk pluralisme in de publieke sfeer, al heeft de staat dit hoofdzakelijk via een cultuurbeleid willen vormgeven. ${ }^{9}$ Met de komst van grote groepen moslims gaat het turbulente Franse verleden weer opspelen. Behalve de zogenoemde commissie-Stasi die eind 2003 adviseerde ostentatieve religieuze symbolen te verbieden in publieke ruimten, zijn er talloze, ook levensbeschouwelijke groepen die zich massaal scharen achter een strikt 'neutrale' republiek als garantie voor rust, orde en religieuze vrijheid (Le Monde 12.12.2003). Zoals een buitenlandse commentator onlangs opmerkte: "one must realize that a militantly secular and neutral French republic is perceived by most citizens as the only possible response to a long and tormented French past, rife with religious tragedy, a story in which Islam is simply the latest arrival" (International Herald Tribune 7.1.2004). ${ }^{10}$

Landen als België, Nederland, Oostenrijk en Duitsland hebben net als Frankrijk geen staatskerk, maar ondersteunen daarentegen religieus pluralisme in bestuurlijke, politieke en culturele zin en in mindere mate ook in juridische zin (o.a. via het familierecht). Ze erkennen en stimuleren soms uiteenlopende religieuze organisaties en proberen die (vaak ook decentraal) via overleg, informatievoorziening en adviesorganen te laten deelnemen aan het bestuurlijke, politieke en culturele leven. Noorwegen, Denemarken, Finland, Engeland en Schotland combineren een relatief zwakke staatskerk met een beperkte mate van bestuurlijk, politiek en cultureel pluralisme. In principiële en juridische zin accommoderen ze geen pluralisme; ze geven vooral een heel pragmatische invulling aan de roep om institutionalisering van uiteenlopende religies. De nieuwe en aankomende EU-lidstaten voegen nog meer uiteenlopende tradities en arrangementen toe aan de bestaande diversiteit in Europa. Hoewel hun stelsels onderling weer flink verschillen, hebben ze alle de vrijheid van religie grondwettelijk verankerd, geheel conform het politieke Kopenhagen-criterium. Tegelijkertijd ontkomen ook deze landen in de praktijk niet aan een zekere voorkeursbehandeling voor de traditionele geloofsgemeenschappen. In een aantal landen, waaronder Bulgarije, 
Roemenië en Litouwen, gaat het echter om een welbewust beleid waarmee de staat de dominante religie inzet als een belangrijke bindende factor voor natievorming (U.S. Department of State 2002; Jubilee Campaign 2003).

\subsection{CONCLUSIE}

Blijkens de uitgangspunten van de Verdragen is de EU een verbond dat berust op politieke en burgerlijke waarden van de democratische rechtsstaat. De Unie is nadrukkelijk geen verbond waarvan de (potentiële) lidstaten specifieke cultuurhistorische of religieuze waarden zouden moeten onderschrijven. Niettemin berust het politiek-burgerlijke waardenverbond op de veronderstelling van een aanwezige democratische rechtsstaat die de autonomie van staat en religie en algemene religieuze vrijheden en rechten garandeert. Hoe de lidstaten die autonomie, vrijheden en rechten gestalte geven en wat de positie van de religie is, blijkt in de nationale praktijk sterk te variëren. De feitelijke plaats van de religie in Europa laat zich derhalve niet zomaar vangen in de minimumvoorwaarden van 'de' seculiere Europese democratische rechtsstaat, noch in de standaardconcepten van het nog altijd veelgebezigde moderniseringsdenken. Volgens dit denken hebben moderne Europese staten alle een min of meer vergelijkbaar ontwikkelingstraject doorgemaakt dat is uitgemond in een onvermijdelijke privatisering van het geloof, vergaande ontkerkelijking en de volledige scheiding tussen kerk en staat. In werkelijkheid kennen deze landen uiteenlopende, historisch gegroeide verhoudingen tussen religies, kerken, staat en maatschappij, met opmerkelijk diverse en vaak ogenschijnlijk tegenstrijdige juridische, institutionele en beleidsarrangementen.

Dit alles impliceert dat er geen eenduidig en vaste Europese standaard voorhanden is waaraan de huidige Turkse situatie kan worden afgemeten. Evenmin zijn er a priori redenen om aan te nemen dat Turkije wel of niet zou passen bij één of meer Europese ontwikkelingsmodellen. Daar komt nog bij dat deze modellen of arrangementen zelf evenmin blijvend verankerd liggen. Door interne en externe veranderingen zoals de opkomst van nieuwe geloofsrichtingen en -genootschappen en toenemende individualisering, moet steeds opnieuw worden gezocht naar een redelijke afweging en balans tussen uiteenlopende belangen en waarden in de democratische rechtsstaat. Het gaat dan bijvoorbeeld om de feitelijke dominantie van de religieuze meerderheid ten opzichte van de religieuze ontplooiingskansen van de minderheid; vrijheid van geweten versus gelijke behandeling en gelijke kansen; bescherming van het afvallige individu tegenover religieuze autonomie van de geloofsgemeenschap, enz. Kortom, er is alle reden om de plaats van de Turkse islam te onderzoeken vanuit een historisch perspectief en te plaatsen in de context van het veranderende evenwicht tussen staat, politiek en samenleving. Dit zal gebeuren in het volgende hoofdstuk. 


\section{NOTEN}

Enkele voorbeelden kunnen dit illustreren. Ten tijde van de Grieks-Perzische oorlogen (vijfde eeuw v. Chr.) duikt het woord Europa met enige regelmaat op als territoriaal concept. Het betrof het door 'barbaren' bewoonde gebied dat zich ten noorden van de Griekse staten bevond en dat zich in taal, gewoonten en waarden duidelijk onderscheidde van de Griekse, en van de 'Aziatisch' Perzische gebieden (McCormick 2002: 31). Op kaarten uit de Oudheid werd de oostelijke grens van Europa vaak getrokken bij de rivier de Don. In de hoogtijdagen van het Romeinse Rijk (20o v. Chr. - 400 n. Chr.) werd een groot deel van dit Europa voor het eerst onder een gemeenschappelijk bestuur gebracht, maar het zwaartepunt van het Rijk lag in de regio van de Middellandse zee, inclusief delen van NoordAfrika en het Midden-Oosten.

Het gewijzigde artikel 7 van het Verdrag van Nice luidt nu als volgt:

1 "Op een met redenen omkleed voorstel van een derde van de lidstaten, het Europees Parlement of de Commissie kan de Raad, na instemming van het Europees Parlement, met een meerderheid van viervijfde van zijn leden constateren dat er duidelijk gevaar bestaat voor een ernstige schending van in artikel 6, lid 1, genoemde beginselen door een lidstaat, en die lidstaat passende aanbevelingen doen. Alvorens die constatering te doen, hoort de Raad de betrokken lidstaat en kan hij volgens dezelfde procedure onafhankelijke personen vragen binnen een redelijke termijn een verslag over de situatie in die lidstaat voor te leggen.

De Raad gaat regelmatig na of de redenen die tot zijn constatering hebben geleid nog bestaan.

2 De Raad, in de samenstelling van staatshoofden en regeringsleiders, kan met eenparigheid van stemmen, op voorstel van eenderde van de lidstaten of van de Commissie, en na instemming van het Europees Parlement, een ernstige en voortdurende schending van in artikel 6, lid 1, genoemde beginselen door een lidstaat constateren, na de regering van de lidstaat in kwestie om opmerkingen te hebben verzocht.

3 Wanneer de in lid 2 bedoelde constatering is gedaan, kan de Raad met gekwalificeerde meerderheid van stemmen besluiten tot schorsing van bepaalde rechten die uit de toepassing van dit Verdrag op de lidstaat in kwestie voortvloeien, met inbegrip van de stemrechten van de vertegenwoordiger van de regering van die lidstaat in de Raad. De Raad houdt daarbij rekening met de mogelijke gevolgen van een dergelijke schorsing voor de rechten en verplichtingen van natuurlijke en rechtspersonen.

De verplichtingen van de lidstaat in kwestie uit hoofde van dit Verdrag blijven in ieder geval verbindend voor die lidstaat.

4 De Raad kan naderhand met gekwalificeerde meerderheid van stemmen besluiten om krachtens lid 3 genomen maatregelen te wijzigen of in te trekken in verband met wijzigingen in de toestand die tot het opleggen van de maatregelen heeft geleid. 
5 Voor de toepassing van dit artikel besluit de Raad zonder rekening te houden met de stem van de vertegenwoordiger van de regering van de lidstaat in kwestie. Onthouding van stemming door aanwezige of vertegenwoordigde leden vormt geen beletsel voor het aannemen van de in lid 2 bedoelde besluiten. Een gekwalificeerde meerderheid wordt omschreven als hetzelfde aandeel van de gewogen stemmen van de betrokken leden van de Raad als vastgelegd in artikel 205, lid 2, van het Verdrag tot oprichting van de Europese Gemeenschap.

Dit lid is eveneens van toepassing wanneer stemrechten worden geschorst op grond van lid 3 .

6 Voor de toepassing van de leden 1 en 2 besluit het Europees Parlement met een meerderheid van tweederde der uitgebrachte stemmen en tevens bij meerderheid van zijn leden."

Voorwaarde is wel dat de lidstaten het eens worden over wat een 'ernstige schending' is.

Dit vloeit mede voort uit de verplichtingen in artikel 9 van het Europese Verdrag voor de Rechten van de Mens uit 1951 over de vrijheid van gedachte, geweten en godsdienst: "1. Een ieder heeft recht op vrijheid van gedachte, geweten en godsdienst; dit recht omvat tevens de vrijheid om van godsdienst of overtuiging te veranderen, alsmede de vrijheid hetzij alleen, hetzij met anderen, zowel in het openbaar als privé zijn godsdienst te belijden of overtuiging tot uitdrukking te brengen in erediensten, in onderricht, in praktische toepassing ervan en in het onderhouden van geboden en voorschriften. 2. De vrijheid zijn godsdienst te belijden of overtuiging tot uiting te brengen, kan aan geen andere beperkingen worden onderworpen dan die die bij de wet zijn voorzien en in een democratische samenleving noodzakelijk zijn in het belang van de openbare veiligheid, voor de bescherming van de openbare orde, gezondheid of goede zeden of voor de bescherming van de rechten en vrijheden van anderen." De uitkomsten van deze vier historische processen zijn in navolging van Bader (2003b: 58) als volgt te typeren: 1. volledig monopolie: alle katholieke of orthodoxe lidstaten; 2. duopolie of gelaagd pluralisme: protestantse lidstaten met een aanzienlijke katholieke minderheid (van 6o-4o procent); 3. gekwalificeerd pluralisme: meer pluralistisch, met een concurrentie tussen de gevestigde staatskerk en een aanzienlijke groep 'dissidente genootschappen' buiten en binnen de staatskerk; 4. compleet pluralisme: volledige concurrentie tussen alle religieuze genootschappen.

6 In Nederland was het de eerste volksvertegenwoordiging, de Nationale Vergadering, die in 1796 proclameerde: "Er kan of zal geen bevoorrechte noch heerschende Kerk in Nederland meer geduld worden.” De grondwet van 1848 maakte daadwerkelijk een einde aan de staatsrechtelijke bevoordeling van de Nederlands Hervormde Kerk en in 1871 werd het ministerie van eredienst afgeschaft. De latere grondwetswijziging van 1917 en de onderwijswet van 1920 gaven een grote mate van autonomie aan religieuze gemeenschappen. De grondswetsherziening van 1983 verbrak de financiële banden tussen de staat en de kerken (waaronder de salariëring van religieuze functionarissen) (Sunier 2004).

$7 \quad$ Hoeveel sporen de staatskerk bijvoorbeeld in Engeland heeft achtergelaten, werd de meeste Engelsen pas duidelijk in het jaar 2002. Madeley beschrijft dat de krant 
The Guardian aan de vooravond van het gouden jubileum van Elizabeth II als vorstin een campagne lanceerde voor het intrekken of amenderen van de Act of Settlement uit 1701, volgens welke alleen protestantse erfgenamen van prinses Sofia van Hannover de troon zouden kunnen bestijgen. Intrekken van de wet bleek een omvangrijke aangelegenheid te zijn, aangezien ook acht andere, daaraan verbonden wetten en nog eens alle vergelijkbare wetgeving in tenminste 15 landen van de Commonwealth zouden moeten worden aangepast (Madeley, te verschijnen).

In hetzelfde jaar speelde ook de opvolging van de aartsbisschop van Canterbury. Volgens de wet moet de Engelse premier de opvolger aanwijzen uit twee kandidaten die zijn voorgedragen door de Crown Appointments Committee. De daadwerkelijke benoeming vindt plaats door de koningin, die als hoofd van de kerk bij haar aantreden als vorstin heeft gezworen de protestantse staatsgodsdienst in Engeland te handhaven. Eenmaal gekozen, dient de aartsbisschop plaats te nemen naast de andere 25 bisschoppen (de Lords Spiritual) in het Hogerhuis. Pas in 1998 zette Engeland formeel het EVRM om in wetgeving, waardoor de in de Act of Settlement vastgelegde discriminatie op grond van onder meer godsdienst niet langer rechtsgeldig was. The Guardian omschreef de Act als "part of the complex web of arcane legislation that binds the monarch to and government with the Church of England" en als een mogelijke stap op weg naar het afschaffen van de staatskerk, maar sommige bisschoppen en ook de vertrekkende aartsbisschop noemde de staatskerk "an essential bulwark of British society" (geciteerd in: Madeley, te verschijnen). Deze voorbeelden van verstrengeling tussen kerk en staat zouden gemakkelijk kunnen worden beschouwd als de wat excentrieke uitingen van de Engelse voorliefde voor traditie. Maar ook elders in Europa staat de relatie tussen religieuze instellingen, staat en maatschappij in allerlei verschillende varianten op de politieke agenda. onlosmakelijk verbonden waarden: vrijheid van geweten, gelijke rechten op geestelijk en religieus terrein en neutraliteit van de politieke macht. In de woorden van de commissie: "L'égalité en droit prohibe toute discrimination ou contrainte et l'Etat ne privilégie aucune option. Enfin le pouvoir politique reconnaît ses limites en s'abstenant de toute immixtion dans le domaine spirituel ou religieux. La laïcité traduit ainsi une conception du bien commun. Pour que chaque citoyen puisse se reconnaître dans la République, elle soustrait le pouvoir politique à l'influence dominante de toute option spirituelle ou religieuse, afin de pouvoir vivre ensemble." Zie ook: http://www.laic.info/Members/webmestre/ Folder.2003-09-11.4517/rapport-stasi.pdf. bepaalde belastingvoordelen genieten en in aanmerking komen voor subsidies (Waardenburg 2001: 71). De conclusies van de commissie-Stasi hebben niet alleen binnen Frankrijk maar ook elders in de EU en in Nederland tot forse discussies geleid tussen voor- en tegenstanders van het Franse model. Voor de Franse ambassade in Nederland was dit aanleiding het thema te behandelen op de eigen website, onder de titel: "Debat over de laïcité: veelgestelde vragen." 


\section{DE TURKSE ISLAM EN DE EUROPESE UNIE}

\section{$3.1 \quad$ INLEIDING}

Veel beschouwingen contra een Turks EU-lidmaatschap gaan ervan uit dat 'islam' en Europa twee verschillende entiteiten zijn die historisch weinig met elkaar van doen hebben. Moslims vormen in die optiek vaak een voor Europa nieuwe groep van naoorlogse immigranten en hun nakomelingen, die zich vooral de laatste decennia steeds vaker zouden manifesteren als aanhangers van een fundamentalistische islam. Dergelijke beschouwingen gaan vaak uit van sterke generalisaties, waarin het Westen en de islam synoniem zijn voor afzonderlijke beschavingen die in belangrijke opzichten haaks op elkaar staan. Volgens Samuel Huntington (1993 en 1996) zullen zich inderdaad juist tussen deze twee 'beschavingsblokken' steeds meer gewapende conflicten voordoen. Zijn hypothese bevestigt het idee van moslims als een ogenschijnlijke collectiviteit van traditionele en wellicht fundamentalistische gelovigen met een vaak antiwesterse gezindheid. De islam komt daarin naar voren als een antidemocratische religie die onder andere gekant is tegen de scheiding van religie en staat. Moslims zouden deze scheiding waar ze bestaat liefst ongedaan willen maken en ook uit zijn op het invoeren van de shari'a, het islamitisch recht. Vanuit dit perspectief van 'botsing tussen beschavingen' zou Turkije, als land met een moslimbevolking, niet passen in de EU. De kern van de Unie als waardenverbond betreft immers juist democratie, respect voor universele mensenrechten en rechtsstatelijkheid.

Dit hoofdstuk onderzoekt op welke manier de moderne Turkse staat vanaf zijn oprichting formeel en feitelijk invulling geeft aan de seculiere democratische rechtsstaat. Het begint met een verkenning van de mate waarin de seculiere staat in Turkije historisch is verankerd (par. 3.2). Vervolgens onderzoekt het hoe de Turkse staat sinds de jaren vijftig is omgegaan met de opkomst van nadrukkelijk op islamitische grondslag gebaseerde politieke bewegingen (par. 3.3) en op welke wijze de Turkse staatsislam zich verhoudt tot de vrijheid van godsdienst (par. 3.4). Daarna belicht het achtereenvolgens de relatie tussen de politieke islam enerzijds en democratie, mensenrechten en geweld anderzijds (resp. par. 3.5, 3.6 en 3.7).

\subsection{DE SECULIERE STAAT: HISTORISCH FUNDAMENT}

Historisch gezien is de periode dat Europa zich als 'vrij' van moslims kan beschouwen maar heel kort geweest. Wanneer de aandacht zich tot deze fase beperkt, valt de eeuwenlange aanwezigheid van de vele moslims in Griekenland buiten beeld. Hetzelfde geldt voor het feit dat het Osmaanse rijk lange tijd deel uitmaakte van het gebied dat nu meestal als Europees grondgebied wordt beschouwd. De relatie met het Osmaanse rijk, waarvan het huidige Turkije het centrum vormde, kende periodes van vijandschap en oorlog. Ze staan aan de basis van het in Europa diepgewortelde vijandbeeld van de islam, een beeld dat de Europese identiteit zelfs mede heeft versterkt (Zemni 2002). Maar de relatie 
kende evenzeer periodes van normale samenwerking en onderlinge beïnvloeding.

De huidige Republiek Turkije getuigt in vele opzichten van deze Europese invloed, waaraan ze zich ook sinds haar bestaan zeer uitdrukkelijk heeft blootgesteld. Het vrijwaren van de staat van religieuze bemoeienis is in Turkije weinig minder rigoureus dan in Frankrijk, dat zijn rol als onbetwiste Europese kampioen van het laïcisme begin 2004 herbevestigde door 'ostentatieve religieuze symbolen' te weren van het openbaar onderwijs. Het in Frankrijk geldende laïcisme, dat de staat institutioneel volledig afschermt van religieuze invloeden, heeft tot op zekere hoogte model gestaan voor Turkije en vertaalt zich vaak in vergelijkbare standpunten, zoals het weren van de hoofddoek in regeringsgebouwen en publieke functies.

Het afschermen van de staat voor religieuze beïnvloeding is dermate sterk dat het Europees Parlement van de Turkse regering zelfs "een meer ontspannen omgang met de islam en de godsdienst in het algemeen" verlangt ter vermindering van intolerantie en gewelddadig religieus extremisme (Europees Parlement 2003). Aldus doet zich nu de paradoxale situatie voor dat de seculiere Unie een minder streng laïcistische houding eist van een regering van een moslimland. Het tegengaan van religieuze invloed op de staat is in Turkije echter veel verder doorgevoerd dan in de meeste EU-lidstaten. In feite neemt het secularisme de vorm aan van onderschikking van de islam aan de staat. Precies omgekeerd derhalve aan een theocratische staatsordening, waarbij de statelijke sfeer ondergeschikt is aan het religieus gezag. Het is juist deze theocratie, zoals momenteel in Iran, die het Westen beschouwt als het probleem bij uitstek van de politieke islam.

De huidige Turkse regering van islamitische signatuur is een groot voorstander van EU-toetreding, ook omdat zij in de Unie garanties ziet voor een betere bescherming tegen de staat en het leger van de vrijheid van godsdienst (zie hieronder). Ze onderschrijft de EU-eis van een meer ontspannen omgang met de islam, maar tegelijkertijd moet de regering omwille van haar lidmaatschapsambities wel spitsroeden lopen. Ze moet rekening houden met de anti-islamgevoeligheden bij zowel de bevolkingen, wellicht ook regeringen van de EU-lidstaten, als bij die van het establishment in eigen land, dat vooral is geconcentreerd in het staatsapparaat (waaronder het leger) en de rechterlijke macht. De door dit establishment gekoesterde scheiding van religie en staat kent een lange voorgeschiedenis. Het seculiere karakter van de staat is dan ook algemeen geaccepteerd. Zoals hieronder zal blijken, hebben de controverses dan ook vooral betrekking op de maatschappelijke en politieke rol van de islam.

De zogenoemde kemalistische staatsideologie van Turkije voert terug naar de opvattingen die zijn ontwikkeld door Mustafa Kemal Pasja (later Atatürk genoemd), de eerste president van de Republiek Turkije (1923-1938). Zijn streven was de natie te moderniseren en aldus Turkije op te stoten in de vaart der 
(westerse) volkeren. Hij was niet tegen de islam als zodanig, maar zag 'de ware islam' als een rationele en natuurlijke religie. Als individuele geloofsovertuiging had ze geen middelaars nodig tussen mens en God. Vanuit deze opvatting zag hij religieuze instituten, zoals het kalifaat (bestuur van de moslimgemeenschap) en de oelema (de godsdienstgeleerden), als sta-in-de-weg; de eerste institutie hief Atatürk derhalve op en de tweede plaatste hij onder staatscontrole. Buiten die controle opererende bewegingen, zoals de in Turkije zo populaire mystieke soefiordes, werden verboden. Het familierecht, het enige rechtsgebied dat toen nog op de shari'a was gebaseerd, werd afgeschaft en gebaseerd op het Zwitsers burgerlijk wetboek. Turkije werd grondwettelijk een seculiere staat. Atatürk kende deze staat bij de modernisering een centrale rol toe. Na de Tweede Wereldoorlog zou het leger die rol steeds meer naar zich toetrekken. Deze missie, die veel weerstand opriep onder delen van de bevolking, vertaalde zich ook in een cultureel offensief gericht op het weren van islamitische symbolen uit het openbare leven, waaronder de traditionele hoofdtooi van vrouwen en mannen en het sluiten van opleidingen voor predikers en de theologische faculteit.

In hun hierbij gaande studie maken Zürcher en Van der Linden duidelijk dat deze secularisatie niet pas begon met Atatürk in de jaren twintig van de vorige eeuw. Die hervormingen vormden juist het sluitstuk van bijna een eeuw van secularisatie van statelijke instellingen. En zelfs de daaraan voorafgaande periode kan feitelijk niet worden getypeerd als een theocratie, in weerwil van dit door de toenmalige islamitische rechtsgeleerden inderdaad gekoesterde ideaal. Hoewel officieel islamitisch, was de Osmaanse staat van oudsher in de praktijk al een seculier bestuursapparaat. Het islamitische rechtssysteem had zelf maar een beperkte reikwijdte en betrof met name het familierecht en het overeenkomstenrecht. Het bestuur van het zo grote rijk vergde vanzelfsprekend zeer veel regels ten aanzien van vele andere gebieden; de oelema had slechts tot taak te verklaren dat deze niet strijdig waren met de religieuze wet. De functie van de leidende oelema was derhalve om het beleid religieus te legitimeren; de islam vormde zo de culturele en politieke brug tussen de staatselite en de massa van de bevolking. Juist deze tweehoofdigheid van het Osmaanse rijk, een autonome beslissingsbevoegdheid van de vorst en religieuze sanctionering hiervan, bracht al in de negentiende eeuw een moderniseringsbeweging op gang. Na een reeks nederlagen werden de staatsinstellingen naar Europees voorbeeld gemoderniseerd, wetboeken geïntroduceerd, nieuwe rechtbanken ingericht, e.d. Omdat vooral Frankrijk model stond, waren deze vernieuwingen gebaseerd op de principes van de laïciteit. In deze eeuw kreeg het Osmaanse rijk dus de gestalte van een moderne staat. Modernisering ging gepaard met uitdrukkelijke verwijzingen naar de religieuze wet, maar feitelijk vormde zich een elite met een materialistisch, natuurwetenschappelijk en geseculariseerd wereldbeeld.

Net als bij de andere Europese vorstenhuizen kwam na 1848 het principe van de godssoevereiniteit van de sultan in discussie. Ook begon de zoektocht naar een nieuw soort legitimiteit in termen van nationalisme ('osmanisme') en democratie; het begrip burgerschap kwam op. In 1876 kwam de eerste grondwet tot stand 
en werden verkiezingen gehouden voor het eerste Osmaanse parlement, met proportionele vertegenwoordiging van het toen nog grote aandeel van nietmoslims (ca. 40\%). Deze data liggen niet ver af van de West-Europese pendanten. De grondwet, die overigens geen staatsreligie regelde, en het parlement werden wel bepleit in een islamitisch getoonzet vertoog met als kern: democratie is inherent aan de islam.

Door het vredesverdrag van Berlijn (1878) na de verloren oorlog tegen Rusland moest niet alleen grondgebied worden afgestaan, maar kreeg het rijk ook steeds meer een moslimbevolking. Op de politieke liberalisatie volgde dan ook een ideologische reactie gericht op het scheppen van een nieuwe basis voor solidariteit onder de moslimonderdanen en het geven van nieuwe mystiek en zeggingskracht aan het sultanaat. Dit sterk religieus gekleurde nationalisme, gericht op het inzetten van de islam als sociaal cement en als middel ter versterking van de staatsmacht, leidde onder sultan Abdülhamit II (1876-1909) tot een grote staatsbemoeienis met de inhoud en verspreiding van het geloof. Daarnaast leidde het tot een enorme uitbouw van staatsfuncties ten aanzien van onderwijs, communicatie en transport. Zürcher en Van der Linden zien ook deze periode als een van de belangrijke constituerende periodes voor de staatsopvattingen van de latere Republiek.

De constitutionele revolutie van 1908 door de 'Jong Turken' leidde tot herstel van grondwet en parlement en de val van de sultan. Inhoudelijk vormde het voorgestane nationale reveil in zekere zin echter een voortzetting van de ideologie van Abdülhamit II: deze beoogde vergroting van de staatsmacht, centralisatie en standaardisatie, met als samenbindend element het behoren tot de islamitische bevolkingsgroep. Dit accent op de islam in de nationalistische ideologie werd uiteraard verhevigd door de Balkanoorlog, waarin het Osmaanse rijk werd aangevallen door vier christelijke Balkanstaten. De Jong Turken stonden overigens een moderne, voor de wetenschap openstaande islam voor, die moest worden gezuiverd van het bijgeloof van de soefisjeiks en het conservatisme van de oelema. In deze periode volgden tal van maatregelen gericht op het terugdringen van de rol van religieuze instellingen (bijv. t.a.v. onderwijs, recht, ziekenhuizen) en het vergroten van de staatscontrole hierover. Atatürk en de zijnen behoorden tot de radicale vleugel van deze Jong Turken en het door hen ontwikkelde kemalisme borduurde voort op het programma van de Jong Turken.

Tot de Tweede Wereldoorlog waren ontwikkelingen als de feitelijke en later formele secularisatie en de staats- en natievorming alle van bovenaf opgelegd en sloegen ze vooral aan bij de stedelijke bevolking. Geen van de successievelijke machtscentra ging echter aan de islam voorbij; dat was immers de religie en de vanzelfsprekende vocabulaire van een steeds meer uit moslims bestaande bevolking. Maar altijd waren het de behoeften van de staat die bepaalden welke politieke rol deze religie institutioneel kon of mocht spelen. Deze hiërarchische en paternalistische maatschappijordening en de door deze structuur opgelegde modernisering waren overigens aan vooroorlogs West-Europa ook niet vreemd. 
Samuel Huntington (1996: 91-3) betitelt de door Turkije aan Europa - met name Frankrijk - ontleende westerse politieke concepten, zoals scheiding van geestelijke en wereldlijke macht, als geleend van en dus minder van binnenuit komend dan in West-Europa. Bij dergelijke politieke instituties gaat het in zijn ogen dus eigenlijk om een voor dat land wezensvreemd element, dat derhalve minder zou zijn beklijfd dan in West-Europa. De hiervoor gegeven historische schets wijst echter juist voor zaken die essentieel zijn voor EU-lidmaatschap op belangrijke gelijkluidende en zelfs min of meer gelijktijdige ontwikkelingen in Turkije en Europese landen. De afbrokkelende macht van de soevereine vorst, het terugdringen van de invloed van de religieuze instituties op de staat, de veranderende legitimatiegrond van het machtscentrum, de doorwerking van het erfgoed van de Franse Revolutie en de napoleontische tijd, de opkomende democratie: al deze processen vonden ook in Turkije plaats en niet veel later dan in West-Europese staten. Turkije nam inderdaad veel over van West-Europa, van Zwitserland, België, Duitsland, Italië en vooral Frankrijk (Koçak 2003). Dit is geen wonder want in West-Europa zetelden de voornaamste wereldmachten. Zoals de Verenigde Staten nu, vormden ze de vanzelfsprekende referentiepunten. Frankrijk was toen juist voor tal van constitutionele kwesties een belangrijke inspiratiebron voor veel landen. Ook Nederland baseerde zich bij de constituties naast Duitsland op Frankrijk en 'imiteerde' hiernaast eveneens zeer veel Franse wetten en instituties; dit maakt de verinnerlijking er echter nog niet minder om. En dit geldt volgens Zürcher en Van der Linden evenzo voor Turkije.

\subsection{SECULIERE STAAT EN POLITIEKE ISLAM}

De onder het kemalisme zo sterk top-down gerichte culturele en politieke modernisering naar Europees model, waarbij de islam als vermeend reactionair obstakel zozeer naar de marge werd gedrukt, maakte na de Tweede Wereldoorlog plaats voor een grotere invloed van onderop. Turkije sloeg - onder meer uit angst voor de communistische Sovjet-Unie en onder Amerikaanse invloed - de weg naar democratie in en voerde in 1946 de meerpartijendemocratie in. De vele kiezers op het platteland, waar de kemalistische modernisering nog weinig invloed had gehad, werden nu een relevante factor, evenals de opposanten van Atatürks autoritaire de-islamisering van niet alleen het politieke maar ook het publieke leven (Erdoğan 1999). Dit bracht na 1950 aanvankelijk niet-religieuze politieke partijen aan de macht die meer ruimte gaven aan de islam, onder andere via het herinvoeren van islamitisch onderwijs op school en van opleidingen voor predikers, het weer toelaten van de gebedsoproep in het Arabisch, e.d. Dit riep echter grote argwaan op van de kemalisten en van het leger, dat zich na 1960 steeds meer ging beschouwen als bewaker van de erfenis van Atatürk (Yesilkagit 1997). Sterk denkend in termen van staatssoevereiniteit hadden zij moeite met de mogelijke consequenties van volkssoevereiniteit. Toch werd het seculiere karakter van de staat en de wetgeving niet in twijfel getrokken door de niet-religieuze Democratische Partij en haar opvolger, de evenmin religieuze Gerechtigheidspartij, noch werd getornd aan de staatscontrole op moskeeën en moefti's. Feitelijk kwamen dus vanaf deze periode volgens Zürcher en Van der Linden 
twee opvattingen van secularisme tegenover elkaar te staan: de kemalistische visie, die secularisme zag als een verdedigingsmechanisme dat de vrijheid van denken moest waarborgen tegenover de islam, en een secularisme dat de staat wilde vrijwaren van religieuze invloed, maar tegelijk de door de staat te respecteren vrijheid van geloof voorstond. In de woorden van Süleyman Demirel van de Gerechtigheidspartij: de staat behoort seculier te zijn, maar dit betekent nog niet dat het individu dit eveneens moet zijn.

Vanaf de jaren zestig ontwikkelde zich een politieke beweging die zich uitdrukkelijk baseerde op de richtlijnen van de islam. De opkomst reflecteerde volgens Zürcher en Van der Linden niet een grotere vroomheid, maar was eerder de resultante van sociaal-economische ontwikkelingen. Hieraan kan worden toegevoegd dat het weinig verbazing wekt dat deze beweging op het politieke toneel verscheen zodra de democratie daartoe de opening bood (zie ook Erdoğan 1999). De beweging articuleerde de verlangens en gevoelens van de kleine ondernemers en de traditioneel ingestelde burgerij die zich in tegenstelling tot grootindustriëlen en arbeiders niet vertegenwoordigd zagen in het bestaande politieke spectrum. Het islamitische van het politieke programma (de 'Nationale Visie', oftewel Milli Görüss) van deze partij, waarin Necmettin Erbakan een centrale rol speelde, betrof vooral nadruk op ethiek en moraal in onderwijs en opvoeding, bestrijding van woeker en corruptie, opheffing van artikelen in grondwet en strafwetgeving die politiek gebruik van religie strafbaar stelde, en vrijheid van godsdienst zonder staatscontrole. Aan het kemalistische principe van gelijke rechten voor mannen en vrouwen, zoals aan het uit 1934 stammende nationaal kiesrecht van vrouwen en gelijke rechten op opleiding en werkgelegenheid, werd niet getornd. Secularisme van de staat was het uitgangspunt; vrijheid van geweten en van meningsuiting werden als basis gezien van democratie en mensenrechten.

De partij van Erbakan werd net als de andere partijen bij de militaire staatsgreep van 1980 verboden; bij het establishment leefde namelijk nog altijd het idee dat deze meer 'volkse' islam een antimoderne en antiseculiere kracht vertegenwoordigde. Om de bevolking en vooral de jeugd immuun te maken voor zowel het socialisme als voor radicale, niet door de staat gecontroleerde islamitische bewegingen, ontketende de junta vervolgens een ideologisch offensief. Hierin stond Turks nationalisme voorop; de islam werd vervolgens als een belangrijke component van de Turkse identiteit gezien. De junta ontleende dit beeld aan de ideologie van een andere beweging, de 'Turks-Islamitische Synthese', die was ontstaan in reactie op het linkse klimaat van de jaren zestig. Vooral in de periode tot 1995 zou deze zeer invloedrijk worden. De aanhangers van deze beweging bevonden zich in verschillende conservatieve partijen, vooral in de - overigens eveneens in 1980 verboden - Nationalistische Actie Partij, die sterk appelleerde aan de arme jeugd in de sloppenwijken van de grote steden. Het ideologische offensief legde veel nadruk op de Turkse identiteit, eenheid en harmonie, militaire en autoritaire waarden; de islam werd voorgesteld als een 'verlichte' religie, open voor wetenschap en technologie. Het Presidium voor Religieuze Zaken, de Diyanet, diende 
deze staatsislam als kern van de Turkse nationale identiteit te beschermen en uit te dragen. Vanaf 1980 zijn veel aanhangers van de Turks-Islamitische Synthese op belangrijke posities terechtgekomen binnen vooral ook sectoren als onderwijs en cultuur.

De door Erbakan in 1983 als Welvaartspartij heropgerichte islamitische partij brak electoraal door in de verkiezingen van 1994 en 1995; de islampolitiek van de junta zelf fungeerde waarschijnlijk juist als wegbereider hiervan. De aanhang van de partij moet deels vooral worden gezocht bij de kleine middenstand, de door de economische liberalisering snel groeiende, welvarende Anatolische ondernemersklasse in de provinciesteden en ook de omvangrijke groep migranten die vooral in de jaren tachtig en negentig in nog groteren getale dan voorheen naar de grote steden trokken. Aangezien de staat er niet in slaagde deze migranten de nodige voorzieningen te bieden, waren ze hiervoor aangewezen op particuliere netwerken en vooral het werk van de mystieke broederschappen, die ondanks het verbod zeer actief waren in de steden. Nieuw ingrijpen door het leger leidde tot de val van Erbakan in 1997 en een verbod op diens partij. Als Partij van de Deugd keerde de partij weer terug, maar zonder veel succes. Bij de verkiezingen in 1999 deed ze het slecht en in 2001 werd ze opnieuw verboden. Desalniettemin werd ze vrijwel onmiddellijk heropgericht als Partij van de Gelukzaligheid, met een zeer religieus getint programma, een sterk accent op conservatieve waarden en normen en een streven naar islamisering van het onderwijs. Dit leidde evenwel tot een scheuring, want de jongere garde wilde een veel minder zwaar accent op de religie. Ze hoopte met het oprichten van een nieuwe partij de kans te vergroten als regeringspartij door het leger en de overige onderdelen van het staatsapparaat te worden geaccepteerd. Daarnaast wilden deze jongeren ook hun electorale kansen vergroten. De kiezers hadden namelijk al verschillende malen getoond niet in groten getalen warm te lopen voor een sterk religieus programma. De nieuwe, in 2001 opgerichte Partij voor Gerechtigheid en Ontwikkeling (AK-partij) presenteerde zich dan ook als een brede conservatieve partij, met respect voor islamitische waarden en normen, maar zonder een uitdrukkelijk religieus programma. De partij boekte in 2002 een dermate grote overwinning dat voor het eerst in het naoorlogse Turkije een eenpartijregering kon worden gevormd. Die werd door leger geaccepteerd, zij het dat haar prestaties tot op heden met argusogen worden gevolgd.

Opmerkelijk aan de geschiedenis van deze politieke partijen is dat ook de islamitische politieke formaties die in de laatste decennia in het Turkse politieke landschap opgeld deden, het principe van scheiding van religie en staat deelden, zij het dat ze meer ruimte voor vrijheid van godsdienst voorstonden en - in het geval van de huidige regerende AK-partij - voorstaan dan het kemalisme. De confrontaties tussen het staatsapparaat, waaronder het leger, enerzijds en islamitische partijen anderzijds gingen in essentie om de twee eerdergenoemde opvattingen van secularisme: die waarbij de staat bovengeordend is aan de religie en die waarbij beide twee nevengeschikte, autonome domeinen betreffen. Scheiding van religie en staat is derhalve in Turkije een breed gedeeld fenomeen, en de 
wortels daarvan gaan net als in de meeste Eu-lidstaten ver terug. Anders dan bijvoorbeeld de hierboven aangehaalde Huntington veronderstelt, blijkt het wel degelijk te gaan om een volledig beklijfde karakteristiek. Voor de in Europa bestaande angst dat de ambitie van de politieke islam zou zijn om religie een positie boven de staat toe te kennen, is derhalve in het geval van Turkije geen reden. De Europese beduchtheid berust overigens ook op eigen ervaring met ambities van christelijke zijde ten aanzien van de staat. Zo was het pas bij het Tweede Vaticaanse Concilie (1962-1965) dat de rooms-katholieke kerk besloot het principe van scheiding tussen kerk en staat te aanvaarden. Turks-islamitische bewegingen die een theocratie willen vestigen bestaan wel in Turkije en daarbuiten (Duitsland), maar ze hebben een zeer geringe aanhang (zie paragraaf 3.7).

\subsection{STAATSISLAM EN VRIJHEID VAN GODSDIENST}

De formele scheiding tussen religie en staat en de grondwettelijk gewaarborgde vrijheid van godsdienst nemen niet weg dat - zoals Zürcher en Van der Linden beschrijven - de Turkse staat de facto een stevige controle op de godsdienstuitoefening heeft. Die stamt uit de Osmaanse tijd, al werd ze in de kemalistische hoogtijdagen het verst doorgevoerd. De restricties en de inhoudelijke staatsbemoeienis gaan verder dan in EU-lidstaten gebruikelijk is, en zijn voor de EU dan ook aanleiding de vrijheid van godsdienst in Turkije kritisch te volgen.

Hoe gewenst de vergroting van de vrijheid van godsdienst ook is, toch dient men de typisch Turkse context in aanmerking te nemen. De verstatelijking van de Turkse islam kreeg op twee momenten een belangrijke impuls, in de vroege jaren twintig en in 1982. De ontmanteling in de jaren twintig van de religieuze instellingen, het kalifaat en de şeyhülislam (hoogste religieuze juridisch adviseur), maakte een eind aan de in naam nog bestaande islamitische invloed op de staat. De laatste instelling werd vervangen door de Diyanet, met uitgebreide taken ten aanzien van het religieuze leven, zoals het beheer van de moskeeën, het benoemen van predikers, het geven van instructie over de inhoud van preken en het verbieden van broederschappen e.d. Dit alles maakte de formele verstatelijking en secularisering van het recht mogelijk en effende de weg naar een op de moderne islam gerichte 'volksverheffing'. De staatsgreep van 1980 moet worden geplaatst tegen de achtergrond van het internationaal opkomend fundamentalisme, waarvan het Turkse establishment vreesde dat het ook in Turkije - als moslimland - voet aan de grond zou krijgen. De islamitische politieke partijen werden opgeheven en de Diyanet kreeg in 1982 de grondwettelijke taak de Turkse nationale identiteit te beschermen. Om tegenwicht te bieden tegen ongewenste islamitische invloeden hoorde hierbij de verspreiding van de 'correcte', soennitische islam via de moskee en - verplicht - onderwijs in deze islam, met een sterke nadruk op ethiek, mensenrechten en plichten jegens vaderland en natie.

Deze maatregelen zijn in huidig Europees perspectief vergaand. Dat geldt ook voor het verbod van Erbakans Welvaartspartij in 1998, dat overigens door het Europees Hof voor de Rechten van de Mens (EHRM) rechtmatig werd bevonden. 
Toch zijn er in de naoorlogse periode ook elders in Europa momenten geweest dat staten overwogen partijen te verbieden die ze beschouwden als een bedreiging voor de democratie en rechtsstaat, zoals die van communistische, racistische of fascistische signatuur. De vrees dat het democratische spel partijen aan de macht brengt die de democratie om zeep willen brengen, is de lidstaten van de EU dus ook niet vreemd. Dat de staat ondanks de formele scheiding van religie en staat geprivilegieerde financiële en inhoudelijke bindingen kent met een bepaalde geloofsrichting, zo toonde hoofdstuk 2, komt ook voor in de lidstaten van de Unie, al zal er geen pendant zijn van de Diyanet. Evenzo is de vrijheid van godsdienst in de lidstaten niet ongelimiteerd en heeft beduchtheid voor bijvoorbeeld sektes hier en daar tot een verbod of het onthouden van een vergunning geleid.

Zoals bleek in hoofdstuk 2, laat het dogma van scheiding van kerk en staat onverlet dat de bestaande arrangementen in de EU van lidstaat tot lidstaat verschillen en er overal rechtsstatelijke beperkingen gelden aan de religieuze vrijheid.

Turkije vormt derhalve in het willen beschermen van de constitutionele karakteristieken geen uitzondering. Wel uitzonderlijk is dat een statelijk orgaan zelf mede de inhoud van de religieuze boodschap bepaalt; de boodschappers zelf - de imams - zijn dan ook ambtenaren. Ook in Europese lidstaten waar formeel een staatsgodsdienst bestaat en de betreffende godsdienst derhalve een bevoorrechte positie geniet, betreft het echter toch autonome instituties, zoals de Anglicaanse Kerk in Engeland en de Presbyteriaanse Kerk in Schotland, die verantwoordelijk zijn voor de inhoud. In de soennitische islam, die de overheersende religie vormt in Turkije, bestaat echter geen met een kerkgenootschap vergelijkbare institutie. Eerder zou men de Diyanet kunnen aanmerken als het functionele equivalent ervan, in de zin dat het management van het religieuze personeel en de inboedel een belangrijke taak vormt. Bij de van Europa afwijkende invloed op de 'deugdelijkheid' van het religieus onderwijs zelf moet worden bedacht dat in de lidstaten controle hierop evenmin afwezig is. Daar verloopt invloed via de gelimiteerde geldkraan, de hieraan verbonden voorwaarden en/of het wettelijk kader. Toezicht hierop kan plaatsvinden omdat de betrokken kerkgenootschappen een aanspreekbare rechtspersoon vormen. Dat in Turkije zo'n geïnstitutionaliseerde positie van religie niet bestaat, betekent dat er geen organen zijn waaraan bevoegdheden en verantwoordelijkheden kunnen worden overgedragen. Wanneer er in de soennitische islam geen figuur als de Diyanet zou bestaan, zou iedere moskee in feite geheel autonoom zijn.

De Diyanet telt naast vertegenwoordigers van de traditionele islam ook representanten van de meer moderne soennitische islam. Daardoor beschikt de staatsislam die de moskee en het onderwijs verspreiden over voldoende flexibiliteit en realisme om een veilige middenweg te kunnen bieden, maar straalt hij zeker geen vernieuwing uit. De uitgedragen boodschap betreft een mengeling van maatschappelijk conservatisme, mensenrechten en vrijheden, patriottisme en volgzaamheid tegenover de staat. Het betreft een vanuit het gezichtspunt van de staat veilige boodschap, een veiligheid die blijkens voornoemde arrangementen in de 
meeste lidstaten bereikt wordt door de buiten de staat staande kerkelijke instituties te binden aan een aantal voorwaarden en wettelijk toezicht. De uit historisch oogpunt verklaarbare binding van de Diyanet aan de staat heeft een tegenwoordig meer pluriforme situatie niet voorkomen, zoals onder andere de educatieve activiteiten van de Süleymancis en de Fethullahcilar aangeven. Maar dit betreft vooralsnog een feitelijke, niet een formele erkenning van pluraliteit.

Met de feitelijk groeiende ruimte voor godsdienstvrijheid en de opgekomen politieke partijen op islamitische grondslag is het geen wonder dat er discussie is ontstaan over de positie van de Diyanet, het eruit voortvloeiende verplichte onderwijs in staatsislam en ethiek alsook de aan de positie inherente bevoordeling van een bepaalde religieuze richting. In Turkije zelf is van verschillende kanten dan ook een neutralere houding bepleit van de staat tegenover de religie. De kleinere partij Özgürlük ve Demokrasi Partisi, bijvoorbeeld, heeft de constitutioneel verankerde positie van de Diyanet ter discussie gesteld, en is om die reden ontbonden (Koçak 2004). Voor het staatsapparaat is een verandering van de positie van de Diyanet zeer moeilijk te accepteren, aangezien haar taken en positie immers een belangrijk instrument vormen ter controle van de islam. Was het door een politieke partij ter discussie stellen van de positie van de Diyanet eerder een wettelijke grond voor het verbieden van deze partij, inmiddels is het voornemen - ook na uitspraken van het Constitutionele Hof de betreffende bepalingen te schrappen (Koçak 2004).

Het toetreden van Turkije zou betekenen dat de Unie met een voor haar ongebruikelijk nauwe relatie tussen religie en staat zou worden geconfronteerd. Deze figuur is historisch verklaarbaar, maar gaat verder dan de staatsbemoeienis die sommige van de lidstaten kennen. Op korte termijn kan in deze relatie niet veel verandering worden verwacht, maar op de langere termijn ligt dit anders. Aan voortgaande democratisering is inherent dat de maatschappelijke, waaronder religieuze pluraliteit meer formele erkenning krijgt. Dit zal haar weerslag hebben op zowel de inhoud van de staatsbemoeienis met de godsdienst als wellicht ook de positie van de Diyanet. Zoals uit Zürcher en Van der Lindens weergave van de 'zakcatechismus' blijkt, vormt bijvoorbeeld een deel van de uitgedragen boodschap dat de islam gehoorzaamheid aan de staat gebiedt. Verdere democratisering zal deze islamitische legitimatie van de sterke staat ondergraven en contestatie van het staatshandelen tot een normaal verschijnsel maken. Langs de weg van democratisering, waardoor de maatschappij onder meer via de politieke arena meer invloed krijgt op de staat, zou de door de Diyanet uitgedragen islam een meer burgerlijk-individueel karakter kunnen krijgen. Bovendien zouden de faciliteiten die dit orgaan verschaft dan ook aan andere islamitische stromingen en religies ten goede kunnen komen. Hiermee wordt dan tegelijk de weg gebaand voor een positie die zich minder leent voor beïnvloeding door het machtscentrum dan nu het geval is. 


\subsection{DEMOCRATIE EN POLITIEKE ISLAM}

Naast de kwesties van formele en feitelijke scheiding tussen religie en staat vormt ook de verhouding tussen islam en democratie een belangrijke achtergrond van de aarzelingen binnen de EU over Turkije. Wanneer men de politieke geschiedenis beziet van het naoorlogse Turkije, dan dringt zich immers een beeld van turbulentie op, en daar zit de Unie vanzelfsprekend niet op te wachten. De hardere of zachtere staatsgrepen van 1960, 1971, 1980 en 1997 waren alle gericht tegen onder meer de toenmalige manifestaties van de politieke islam. De politieke islam is derhalve belangrijke splijtstof geweest in het politieke leven van Turkije. Betekent dit dat deze islamitische partijen een gevaar vormden voor de democratie? Waren ze gericht op het omverwerpen ervan of vormden ze er juist de uitdrukking van?

Zoals hiervoor al bleek, hebben de achtereenvolgende islamitische politieke partijen het seculiere karakter van de staat nooit willen aantasten. Ze stonden wel een ander soort secularisme voor dan de kemalistische staatsideologie. De dragers van het kemalistisch erfgoed beschouwden de betrokken partijen als zodanig al als een aantasting van de fundamenten van de Turkse Republiek. De islamitische politieke partijen zagen daarentegen vrijheid van geweten, van meningsuiting, religie en religieuze praktijk als basis van de democratie. Bovendien hebben deze partijen de waarde van democratie programmatisch nooit betwist en hebben ze ook steeds de democratische en rechtsstatelijke spelregels gebruikt voor het uitoefenen van invloed. Zoals Zürcher en Van der Linden aangeven, heeft Erbakan het verbod in 1998 op zijn Welvaartspartij niet in naam van Allah via de straat aangevochten, maar bij het EHRM. Hij heeft zich vervolgens neergelegd bij diens oordeel dat het verbod rechtmatig was. Volgens Yavuz (2003) is het probleem van Turkije derhalve niet dat de tot politieke expressie gekomen islam antidemocratisch of tegen de mensenrechten zou zijn, maar eerder de grote angst van staatsapparaat voor de consequenties van de democratie.

De jaren tachtig en vooral negentig vormden de hoogtijdagen van de islamitischpolitieke doorbraak, zowel op lokaal als nationaal niveau. Gezien de Turkse staatsgeschiedenis, waarin zozeer het accent lag op het ontkennen en onderdrukken van de islam als een relevante politieke factor, is het niet verbazingwekkend dat dit gepaard ging met polarisatie, net als al tijdens de opkomst vanaf de jaren zestig. Deze polarisatie wekt evenmin verbazing in het licht van de internationale ontwikkelingen rond de politieke islam. De politieke manifestatie van de islam via de verschillende verschijningsvormen van Erbakans partij gaf articulatie aan wensen van groepen die zich niet herkenden in het kemalistische project. Hierdoor werden nieuwe bevolkingsgroepen in de publieke ruimte getrokken en bij de politiek betrokken. Tegelijk vormde deze manifestatie zelf de uitdrukking van grote sociaal-economische veranderingen die zich in de Turkse samenleving voltrokken, zoals de onder invloed van de economische liberalisering opkomende nieuwe middenklasse en de massale migratie naar de grote steden. Met de 
islamitische partijvorming, die in belangrijke mate werd gedragen door regionale en lokale organisaties en netwerken, ontstond zo een politieke sector die de samenleving beter vertegenwoordigde dan voorheen (Yavuz 2003: 227-231). Ondanks de botsingen met het establishment en de vele ook recente controverses, is de islam als politiek relevante factor gaandeweg een normaler fenomeen geworden in de Turkse politiek.

Aanvankelijk lag bij deze islamitische partijen een sterk accent op de islam en keerden ze - in reactie op het kemalisme - de blik naar het Midden-Oosten en naar Centraal-Azië. Europa en het kemalisme wezen ze als min of meer verwante oriëntaties van de hand. Volgens Yavuz heeft zich in het daaropvolgende decennium echter een opmerkelijke omkering voltrokken van de houding ten aanzien van de EU. Een deel van het staatsestablishment ziet de EU inmiddels als een bedreiging van het kemalistisch nationalisme, terwijl de aanhangers van de politieke islam juist een verschil zijn gaan zien tussen de EU en het kemalisme. Die aanhangers hebben zich nu massaal geschaard achter EU-toetreding, in de overtuiging dat de Unie juist een vorm van secularisme biedt dat godsdienstvrijheid beschouwt als een te beschermen mensenrecht. Het pleidooi van de Europese instellingen voor democratisering en respect voor de mensenrechten heeft in belangrijke mate bijgedragen aan deze transformatie (Yavuz 2003: 254-261). Dit zou een aanwijzing kunnen zijn voor de pacificerende invloed die uitgaat van het vergroten van de 'normale' politieke kanalen en het verbreden van de politieke arena.

Deze omkering in perspectief betekent overigens niet dat de EU, door het belang van democratie en mensenrechten te benadrukken, tegelijkertijd ook antimoderne krachten in de kaart speelt. Zowel de kemalisten als de Turkse politieke islam zijn zeer sterk beïnvloed door Europese ideeën en praktijken (Yavuz 2003: 265-274). Zoals ook Zürcher en Van der Linden stellen, is Turkije geen kolonie geweest. Daardoor is de islam niet - zoals elders in de moslimwereld - het ideologisch voertuig geweest van een nationalistische verzetsbeweging tegen de westerse overheerser. De desondanks aanwezige westerse invloeden zijn het gevolg van eigen keuzen en niet van afdwinging door vreemde krachten. Hoewel veel veranderingen van bovenaf - door de eigen elite - zijn opgelegd, zijn ze toch primair eigen producten. Het Westen functioneert derhalve ook voor de politieke islam veel minder als vijandbeeld dan in andere moslimlanden het geval is. Voorzover in Turkije al van een vijandbeeld sprake was, betrof dit met name Rusland en later de Sovjet-Unie. Dit resulteerde ook in het lidmaatschap van de NAVO, die het gezamenlijk Turks-Europees-Atlantische militaire kader vormde voor de strijd tegen het communisme. Ook voor de politieke islam vormde het communisme de grootste vijand.

Evenmin als een achtergrond van kolonisatie kende of kent Turkije de massale sociaal-economische deprivatie en frustratie die elders in de moslimwereld mede een voedingsbodem vormen voor extremisme. Anders dan elders in delen van de moslimwereld heeft bestaande onvrede zich bovendien altijd politiek kunnen 
manifesteren: steeds konden regeringspartijen weggestemd worden. Zoals Zürcher en Van der Linden aangeven, zijn er sinds de Tweede Wereldoorlog vijftien nationale verkiezingen geweest, waarvan twaalf vrij en eerlijk. Ook daarom mist de politieke islam in Turkije de extremistische eigenschappen die elders wel voorkomen. Veeleer vormt ze de uitdrukking van een sterk groeiende stedelijke middenklasse, die zich weliswaar religieus geïnspireerd voelt en daarvoor nu ook tegenover de kemalisten erkenning opeist, maar die evenzeer is beïnvloed door tachtig jaar secularisme en kemalisme. Hierbij horen gematigde interpretaties van de islam. Ondanks het formele verbod hebben de soefibewegingen en hun intellectuelen een belangrijke invloed op de Turkse moslims. Ook dit heeft ertoe bijgedragen dat pluralisme en gematigdheid belangrijke kenmerken zijn van de Turkse islam. Zürcher en Van der Linden wijzen hiernaast op de van oudsher bestaande oriëntatie van de islam op de staat, waardoor de islam in Turkije een pragmatisch en flexibel karakter heeft.

Zoals eerder gesteld, kent Turkije evenals Europese lidstaten de laatste paar decennia hoofddoekaffaires. De gaandeweg groeiende erkenning van de islam als maatschappelijk en politiek relevante factor is gepaard gegaan met een bewustwording van juist ook goed opgeleide jongeren dat de islam deel uitmaakt van hun identiteit. Het dragen van de hoofddoek is derhalve bij deze groep zeker geen vertoon van traditionalisme of een uiting van fundamentalisme. De nieuwste categorie draagsters zoekt met dit symbool erkenning van die moslimidentiteit, juist ook in de publieke ruimte die ideologisch daarvoor zo lang en zo uitdrukkelijk was afgesloten (Göle 1996). Zürcher en Van der Linden geven aan dat die erkenning ook niet wordt opgeëist in een theologisch getoonzet vertoog, maar met een beroep op mensenrechten (het individuele recht op het tonen van godsdienstige overtuiging). Algemener gesteld, de doorbraak van de politieke islam heeft het in het kemalistische discours gekoesterde onderscheid tussen 'moderne kemalisten' en 'achtergebleven moslims' doorbroken (Yavuz 2003). Hiermee heeft de staat het ideologisch monopolie op moderniteit verloren. Onder voorwaarde dat het staatsapparaat en dus ook het leger de democratie meer gaan respecteren en de autonomie van de civil society erkennen, kan de zo lang bestaande tegenstelling tussen staat en maatschappij worden opgeheven.

Zürcher en Van der Linden stellen met nadruk dat het beeld moet worden vermeden als zou religie de allesbepalende factor zijn in Turkije. Een studie zoals de zijne en een rapport als het onderhavige, die beide de religie vooropstellen, kunnen gemakkelijk die indruk wekken. Dat geldt ook voor het functioneren van de Turkse democratie. De door verkiezingen van belang geworden rol van de politieke islam zou het beeld kunnen doen postvatten dat de betrokken partijen uitsluitend vanwege hun islamitisch karakter meer of minder succes hebben geboekt. Dat is echter niet zo; het stemgedrag van het electoraat getuigt zeker van het gepercipieerde belang van religie, maar dan wel als één factor onder vele andere. Slechte prestaties ten aanzien van bijvoorbeeld de economie of het onvoldoende tegengaan van politiek geweld werden electoraal afgestraft, ook al betrof het islamitische partijen. Het Turkse electoraat lijkt bovendien een voor- 
keur te hebben voor gematigde partijen, ook gematigd in islamitische zin. Toen het bijvoorbeeld bij de laatste verkiezingen in 2002 geplaatst werd voor de keuze tussen de meer uitgesproken islamitische Partij van de Gelukzaligheid en de gematigde AK-partij koos het in overweldigende mate voor de AK-partij, zelfs in de regio van Erbakan, leider van de Partij van de Gelukzaligheid. Dat een islamitisch geïnspireerde regering een - inmiddels ook door het parlement goedgekeurd - wetsontwerp tegen discriminatie van homoseksuelen zou indienen, zoals de huidige regering recentelijk deed (The Economist 21.2.2004), staat toch wel haaks op het beeld het Westen heeft over islam en moslims.

Deze conclusie wordt bevestigd door attitudeonderzoek. De Turkse bevolking laat zich typeren als weliswaar in meerderheid gelovig, maar zeker niet uitblinkend in grote geloofsijver, tolerant en allerminst fundamentalistisch. De meerderheid is gekant tegen een rol van religie in het politieke leven, steunt het seculiere karakter van de republiek en vindt eveneens dat de staat zich niet met de religie moet bemoeien. $\mathrm{Zij}$ ziet religie als iets voor het private leven en heeft een sterke afkeer van het opspelen van religieuze verschillen (Çarkoğlu en Toprak 200o). Uit Eurobarometer 2002 blijkt voorts dat de Turkse bevolking in meerderheid toetreding tot de EU toejuicht. Deze adhesie behoort tot de hoogste van alle kandidaat-lidstaten. Hierbij moet wel aangetekend worden dat de kennis omtrent de Unie beperkt is. Overigens onderscheidt de Turkse bevolking zich hiermee niet sterk van die van de meeste andere kandidaten (Europese Commissie 2002).

\subsection{RECHTSSTAAT EN POLITIEKE ISLAM}

Zoals in paragraaf 3.2 al werd aangegeven, betreft het in Turkije bestaande recht seculier recht. Koçak (2004) deelt de geschiedenis van het rechtsstelsel in drie periodes in, met als breekpunten 1839 en 1920. In de Osmaanse tijd gold tot 1839 formeel het islamitisch recht, hoezeer ook toen al sprake was van een groot domein van - door de islamitische autoriteiten gesanctioneerd - wereldlijk recht. Vanaf 1839 maakt de islamitische staat plaats voor een staat met een gemengd rechtsstelsel. Zo werden bij het Wetboek van Strafrecht van 1858 (een vertaling van het Franse wetboek van 1810) de traditionele shari'a-straffen grotendeels verboden. Steniging van overspelige vrouwen was overigens al in de zeventiende eeuw afgeschaft. Het in 1850 ingevoerde handelsrecht, dat eveneens aan Frankrijk was ontleend, introduceerde de rente, hetgeen strijdig was met de shari'a. In deze periode bestonden ten aanzien van verschillende rechtsgebieden zowel aparte seculiere en islamitische gerechtshoven als gemengde, maar nam - zij het met golfbewegingen - de invloed van de religieuze hoven af. Het familierecht vormt het rechtsgebied dat het langst werd geregeerd door het islamitisch recht, maar evengoed was het toch nog in de nadagen van het Osmaanse rijk (1917) dat de competentie van religieuze gerechtshoven in familierechtelijke kwesties werd afgeschaft. In 1920 vond de laatste bijeenkomst plaats van het Osmaanse Parlement en de eerste van het Turkse Parlement. Met de vestiging van de Republiek Turkije werden de laatste restanten van het rechtspluralisme 
afgeschaft. In 1924 werden de shari'a-gerechtshoven verboden, en in 1926 werd naar het Zwitserse voorbeeld een nieuw burgerlijk wetboek ingevoerd. Het in regeringsgebouwen dragen van kleding naar religieuze voorschriften werd in 1925 verboden. Het Wetboek van Strafrecht van 1926 verbood het gebruik van religie voor politieke doeleinden. In 1928 werd het nog bestaande artikel dat de islam als staatsgodsdienst aanmerkt, geschrapt en werd in de toelichting de nationale soevereiniteit vereenzelvigd met een laïcistische en democratische republiek (Koçak 2004).

Deze lange geschiedenis van de secularisering van het recht, waartoe geput werd uit de rechtsstelsels van veel Europese staten, zegt op zich al veel over de mate van worteling van dit recht. De secularisering van het recht is geen innovatie geweest van het kemalisme, maar kreeg geleidelijk al vorm in de lange periode dat nog sprake was van een islamitische staat; ook Zürcher en Van der Linden wijzen hierop. Daar komt bij - zo stelt Koçak - dat de vele stappen in dit proces steeds berustten op een eigen keuze. Ze werden niet, zoals elders in de moslimwereld, opgelegd door een koloniale macht of genomen om het Westen te plezieren. Ook dit betekent dat het seculiere recht inmiddels een endogeen kenmerk is van Turkije. Wellicht is het dat nog sterker dan het Turkse establishment zelf aanneemt, want dat reageert immers krampachtig op vermeende inbreuken op het seculiere karakter van de Turkse staat. Hoewel het verbod op het gebruik van religie voor politieke doeleinden inmiddels feitelijk is achterhaald, blijkens de deelname van islamitische partijen aan verkiezingen, spelen bijvoorbeeld hoofddoekaffaires regelmatig hoog op. Ook de plaats van de eerder besproken Diyanet in het overheidsapparaat - nu rechtstreeks vallend onder de minister-president ligt zeer gevoelig. Discussies hierover werden al snel beschouwd als overschrijding van de grenzen die in de grondwet aan het politieke speelveld waren opgelegd.

De Refah Partij werd verboden in 1997; ze werd ervan beschuldigd voorstander te zijn van rechtspluralisme en daarmee van herinvoering van elementen van de shari'a voor moslims en van jihad als politiek instrument. ${ }^{1}$ Hiermee zou volgens het Constitutionele Hof het seculiere karakter van de staat worden aangetast. Dit verbod werd inderdaad rechtmatig bevonden door het EHRM, dat dit oordeel naar eigen zeggen niet baseerde op enig officieel programma van de partij, maar op uitlatingen van individuele partijfunctionarissen. Hierbij dient echter bedacht te worden dat het EHRM deze uitlatingen toetste aan de eerder door de junta ingevoerde grondwet. Ook dit geval illustreert de grote nervositeit van het Turkse (juridische) establishment over een dreigende aantasting door de politieke islam van het seculiere staatsbestel en rechtsstelsel. Het verbod door het Turkse Constitutionele Hof zelf berustte niet op het partijprogramma of de handelingen van de Refah Partij in de regering. In dat programma werd juist het fundamentele principe van het seculiere karakter van de staat onderschreven. De gronden waren een aantal afzonderlijke handelingen van functionarissen (zoals het dragen van de hoofddoek, het pleiten voor de mogelijkheid tot gebed in werktijd) en enkele redevoeringen van de partijleider, Necmettin Erbakan. 
Daarin eiste hij het recht op voor gelovigen onder hun eigen rechtssysteem te leven en bracht hij het vestigen van een rechtvaardige sociale orde in verband met jihad. Het EHRM was overigens zeer verdeeld. Het minderheidsstandpunt zag in de officiële handelingen van de Refah Partij geen dwingende en overtuigende aanwijzing voor aantasting van de seculiere orde, noch een oproep tot geweld of religieuze haat (Koçak 2004).

Met Erbakans oproepen op congressen van zijn eigen partij voor herinvoering van elementen van de shari'a is overigens nog niets gezegd over de electorale populariteit van de shari'a. Blijkens het in de vorige paragraaf aangehaalde sociologisch onderzoek wijst een overgrote meerderheid bijvoorbeeld herinvoering van de heilige wet in het familierecht af. Slechts tien à vijftien procent is voorstander van invoering van familierechtelijke elementen van de shari'a, zoals erkenning van het islamitisch huwelijk of verstoting (Carkoglu en Toprak 200o).

Zijn de principes van de seculiere rechtsstaat stevig gefundeerd in de Turkse geschiedenis en huidige samenleving, hiermee is over de houding ten opzichte van en de implementatie van de mensenrechten nog niets gezegd. Deze kwestie is natuurlijk van groot belang voor de vraag in hoeverre Turkije voldoet aan de Kopenhagen-criteria, en de voortgang vormt dan ook terecht een belangrijk onderwerp van onderzoek in de voortgangsrapportages van de Europese Commissie. Die toets zal hier niet worden verricht, maar de verhouding van de Turkse politieke islam tot de mensenrechten is hier vanzelfsprekend wel een belangrijk punt van aandacht.

Opmerkelijk is dat de politieke islam een plaats opeist in de politieke sfeer met een beroep op de mensenrechten. Zürcher en Van der Linden stellen dat democratie en mensenrechten als referentiekader worden gehanteerd, omdat dit een in de Turkse situatie geaccepteerd discours vormt. Zoals eerder aangegeven, wordt het Europese lidmaatschap juist ook door de islamisten (de aanhangers van de politieke islam) voorgestaan, omdat ze in de EU een betere bescherming van de godsdienstvrijheid zien dan in de kemalistische staat. Dit roept de vraag op in hoeverre het beroep op de mensenrechten niet vooral wordt ingegeven door eigenbelang - een rechtmatige ruimte voor zichzelf - of tevens een erkenning betekent van de rechten van anderen. In zijn door Zürcher en Van der Linden aangehaald boek uit 1975 stelde Erbakan dat zijn beweging trouw is aan alle door de grondwet omschreven rechten en vrijheden. Het Turkse systeem zag hij evenwel als een systeem waarbij door niet-gelovigen aan gelovigen hun mensenrechten worden onthouden. In plaats van de bepaling in de strafwet dat politiek gebruik van religie strafbaar stelt, wilde Erbakan een Wet ter Bescherming van de Mensenrechten. Hier is vermoedelijk uit af te leiden dat het bij zijn beroep op mensenrechten toch in de eerste plaats ging om het veiligstellen van de rechten van gelovigen en van de eigen politieke beweging. Dit is op zich niet verwonderlijk, gezien het vanuit kemalistisch oogpunt controversiële karakter van de godsdienstvrijheid en de tegenstand die Erbakans achtereenvolgende islamitische partijen ondervonden. 
De nu regerende AK-partij is veel explicieter over de hiervoor gestelde vraag. Haar verkiezingsprogramma besteedt zeer veel aandacht aan mensenrechten en doet veel voorstellen om deze in overeenstemming te brengen met Europese maatstaven. Het programma ziet verschillen van geloof, cultuur en geuite meningen als een verrijking, en merkt secularisme aan als een principe van vrijheid dat die pluraliteit juist mogelijk maakt. Bepleit wordt dat mensen met verschillende taal, religie, ras en sociale status zich op basis van gelijke wettelijke bescherming vrijelijk moeten kunnen uiten en als zodanig moeten kunnen deelnemen aan de politiek. Uitdrukkelijk gaat het programma ook in op de gelijke rechten van niet-gelovigen. Vermeld wordt dat deze wenselijkheden en de daartoe voorgestelde maatregelen niet dienen om het toegangsbewijs voor de Unie te verkrijgen, maar op zichzelf noodzakelijk zijn voor de modernisering van het land. Een belangrijke voorwaarde hiertoe is volgens de partij dat de relatie tussen staat en maatschappij verandert. De huidige autoritaire top-down-benadering zal plaats moeten maken voor een staat die zich in dienst stelt van de maatschappij.

Deze benadering toont derhalve veel meer oog voor de positieve betekenis van pluraliteit, ook op religieuze gronden, dan de staat en wellicht ook de Refah Partij voorstonden. Het mensenrechtenconcept van de AK-partij is veeleer een inclusief concept dan een particularistisch concept dat wordt ingezet om zelf aan bod te kunnen komen. Of het handelen van de AK-partij, nu ze regeermacht heeft, getuigt van dezelfde geest, zal moeten blijken uit de rapportages van de Europese Commissie. De meest recente rapportage maakte evenwel gewag van grote vorderingen (Europese Commissie 2003). Ook als men het gebruikelijke retorische karakter van verkiezingsprogramma's verdisconteert, lijken de intenties niet uitsluitend te berusten op politiek opportunisme. De aangehaalde opvattingen weerspiegelen op zichzelf ook veranderingen die al langer gaande zijn in Turkije. De door sociaal-economische veranderingen en stijgend opleidingsniveau ondersteunde verbreding van de politieke basis via de verschijningsvormen van Erbakans partijen vormden een novum voor het land. En net als zijn voorgangers weet ook de huidige AK-partij zich gesteund door lokale en regionale netwerken van activisten die hun - niet zelden vaak uiteenlopende - aspiraties verenigen onder de symbolische vlag van de islam (White 2002). De schoorvoetende erkenning van de islam als relevante politieke factor kon in het kemalistische klimaat alleen worden verkregen door confrontaties, die tot vrij recent dan ook regelmatig hebben plaatsgevonden. Maar hierdoor is de ruimte voor het publieke debat wel verbreed en is de vanzelfsprekendheid van het gelijk van de staat afgenomen. Het lijkt erop dat na de confrontaties van de jaren tachtig en negentig de AK-partij gebruikmaakt van deze eerder veroverde ruimte en inhoudelijk een zekere 'synthese' belichaamt. Blijkens het verkiezingsprogramma is de eerdere polarisatie tussen islamisme en kemalisme overwonnen door een zeer sterk accent op rechtsstatelijkheid. Uitgangspunten zijn de binding van de staat aan het recht, een neutrale positie van de staat ten opzichte van religie, verdere democratisering en 'inclusieve' mensenrechten waarin de vrijheid van meningsuiting een centrale, strategische plaats inneemt. Hiermee weet de partij ook electorale tegenstellingen te overbruggen tussen islamisten en kemalisten. 
De voorwaarden voor het bepleite nieuwe sociaal contract tussen staat en maatschappij lijken derhalve aanwezig. Tegelijkertijd moet men zich realiseren dat in Turkije het vieren van de teugels voor het democratisch proces geen geruisloze aangelegenheid zal zijn.

\subsection{GEWELD EN POLITIEKE ISLAM}

Een bijzondere zorg voor de Europese lidstaten is of met een lidmaatschap van Turkije tevens religieus of religieus-nationalistisch gemotiveerd extremisme en geweld in de Unie worden geïntroduceerd. Weliswaar is religieus geweld ook sommige lidstaten niet vreemd geweest, getuige het slepende conflict tussen de protestanten en de katholieken in Noord-Ierland. Hetzelfde geldt voor nationalistisch geweld, dat zich eveneens al zo lang voordoet rond het onafhankelijkheidsstreven van de Basken in Spanje. Maar gezien de grote aantallen Turken in de diverse lidstaten zou dat - bij hun eventuele ontvankelijkheid voor geweldsuitoefening - veel meer dan een lokaal of nationaal probleem vormen, waartoe genoemde conflicten toch grotendeels beperkt zijn gebleven.

Zürcher en Van der Linden onderscheiden drie ideaaltypische posities in het huidige politiek-religieuze landschap in Turkije: modernisme, traditionalisme en fundamentalisme. De modernisten staan open voor een voortdurende herinterpretatie van het morele ideaal, zoals geopenbaard aan Mohammed. Zij benadrukken de morele zelfstandigheid van het individu en zijn vrijheid en vermogen om voor de veranderende omstandigheden relevante morele kennis te bereiken. De traditionalisten staan interpretatie van het morele ideaal wel toe, maar als deze heeft plaatsgevonden en is bevestigd door de overeenstemming der gelovigen, kan deze niet meer worden herzien. De gezaghebbende tekst van de islam breidt zich hierdoor steeds verder uit met de interpretaties van eerdere generaties. De fundamentalisten verzetten zich echter tegen het recht op en de noodzaak van subjectieve interpretatie en kennen een absolute betekenis toe aan de originele teksten en bronnen; ze willen het maatschappelijke en politieke leven modelleren naar de moslimgemeenschap ten tijde van Mohammed, en de shari'a invoeren. Dit wordt vaak gemotiveerd door de wens om het morele ideaal te behoeden voor manipulatie en corruptie door machthebbers.

De hoofdstroom van de Turkse islam betreft het modernisme en het traditionalisme. Het modernisme, dat de islam primair ziet als een persoonlijke geloofsovertuiging en zich volledig openstelt voor de wetenschap, typeert met name de Jong Turken en de kemalistische interpretaties sindsdien van de islam, evenals belangrijke takken van de Nurcu-beweging. De Nationale Visiebeweging (Milli Görüss) en de Nakşibendi-beweging waar ze uit voortkomt, kunnen tot het traditionalisme worden gerekend. Fundamentalisme behoeft niet gewelddadig te zijn. Dit komt vooral voor bij sommige van de Nurcu-bewegingen, zoals de Aczmendi's, maar ook binnen de Milli Görüş-beweging. Gewelddadig-fundamentalistische bewegingen zijn natuurlijk illegaal; het gaat volgens Zürcher en Van der Linden om een klein aantal, ook in omvang van de aanhang zeer beperkte, maar 
wel actieve bewegingen. Zij rekenen hiertoe allereerst de verboden groepering 'De Stoottroepen van het Islamitische Grote Oosten-Front' (IBDA-C). Deze beweging erkent de Turkse staat niet en streeft naar het opheffen van de verdeeldheid in de islamitische wereld. Ze wijst de Europese invloed op Turkije af en zet hiervoor de islam in de plaats, niet louter als religie maar als beschaving. Ze beschikt over een ondergrondse tak die geweld niet schuwt, mogelijk contacten onderhoudt met al-Qaeda, en vermoedelijk verantwoordelijk is voor de zelfmoordaanslagen in Istanbul in november 2003. Hiernaast is er Hizbullah, die zich als ideaal heeft gesteld een onafhankelijke islamitische staat te vestigen. Ze richtte zich in de jaren negentig ook met terreur tegen de Koerdische PKK en progressieve Turkse en Koerdische zakenmensen en intellectuelen die sympathiseerden met de zaak van de PKK. Deze beweging zou door de veiligheidsdiensten zijn gebruikt in de strijd tegen de PKK; toen dat niet meer nodig was, is ze voor een belangrijk deel opgerold. Het 'Kalifaat van Keulen', een verboden afsplitsing van de Nationale Visie-beweging, wil eveneens de seculiere staat en de democratie in Turkije omverwerpen en heeft vanuit Duitsland het kalifaat uitgeroepen. De beweging is sinds kort in Duitsland verboden, maar de activiteiten gaan ondergronds door.

Deze ondergrondse bewegingen staan in principe niet afwijzend tegenover geweldsuitoefening gericht op het tot stand brengen in Turkije van 'heilige' doelen, zoals het vestigen van een islamitische staat of het opgaan van Turkije in een breed islamitisch verband en invoering van de shari'a. Hun ambities staan niet alleen lijnrecht tegenover de kemalistische opvattingen, maar vormen ook een breuk met de Osmaanse traditie, waarin immers feitelijk een scheiding van religie en staat bestond. Gezien de lange geschiedenis van de seculiere staat, die ook ondersteund wordt door de hoofdstromen van de Turkse islam en - zoals hiervoor gesteld - het overgrote deel van de bevolking, lijken deze doelen derhalve een illusie.

Toetreding van Turkije tot de EU is in de ogen van deze bewegingen vermoedelijk het toppunt van afvalligheid. Dat gedurende de aanloop tot EU-lidmaatschap een intensivering van gewelddadigheden optreedt, wellicht ook in de huidige lidstaten, is dus beslist niet denkbeeldig. Wanneer de Unie hiervoor zou terugschrikken, zou dit betekenen dat deze kleine groepjes extremisten en terroristen in staat worden gesteld het land in gijzeling te nemen en hierdoor van de zo lang gekoesterde en breed door de bevolking gedeelde ambitie af te houden. De door het Europese Parlement bepleite meer ontspannen houding in Turkije tegenover de islam, en dan met name de politieke manifestatie ervan, zou de aanhang van deze extremistische bewegingen wellicht nog verder kunnen terugbrengen. Verkiezingen maken immers duidelijk hoe gering de sympathie van de bevolking werkelijk is voor door dergelijke partijen gekoesterde denkbeelden. 


\subsection{CONCLUSIE}

Net zoals er tussen de huidige EU-lidstaten onderling verschillen bestaan in de ontwikkeling van de formele en feitelijke verhouding van de staat tot de religie, bestaan die er ook tussen de EU-lidstaten en Turkije. Toch vertoont juist op veel gebieden die van essentieel belang zijn voor de seculiere democratische rechtsstaat de Turkse historische ontwikkeling veel parallellen met de Europese. Hoewel officieel islamitisch, kende de Osmaanse staat van oudsher feitelijk al een seculier bestuursapparaat en bleef de reikwijdte van het islamitische recht beperkt tot met name het familie- en overeenkomstenrecht. Ook de Osmaanse en later de Turkse staat werd mede en min of meer gelijktijdig gevormd door de afbrokkelende macht van de soevereine vorst, de afnemende beïnvloeding door religieuze instituties, de veranderende legitimatiegrond van het machtscentrum, de doorwerking van het erfgoed van de Franse Revolutie en de napoleontische tijd, de invloed van staatsrechtelijke innovaties elders in Europa en de opkomende democratie. Tegen die achtergrond van toenemende democratisering manifesteerden zich vanaf de jaren zestig naast de al bestaande maatschappelijke en culturele bewegingen ook politieke partijen die zich nadrukkelijker wilden baseren op islamitisch geïnspireerde waarden en van de staat meer bewegingsruimte opeisten. Daardoor werd ook de wens tot autonomie van het religieuze domein ten opzichte van de staat en de borging van religieuze vrijheden door de staat steeds breder gedragen. Deze opvatting, die aansluit bij de EU-eisen aan de democratische rechtsstaat, vormt inmiddels een belangrijk uitgangspunt voor de aanhangers van de huidige Turkse regering om te streven naar lidmaatschap van de Unie. 


\section{NOOT}

1 Jihad betekent 'streven' of 'strijd'. Het is echter zowel in de moslimwereld als daarbuiten een omstreden begrip met vele verschillende, contextafhankelijke betekenissen. Volgens velen moet er een onderscheid worden gemaakt tussen 'grote jihad', de innerlijke, mentale strijd van de gelovige om het goede te doen, en de kleine jihad, de gewapende strijd ten behoeve van het geloof en de geloofsgemeenschap. Anderen beschouwen jihad vooral als het streven naar (sociale) rechtvaardigheid. 
DE EUROPESE UNIE, TURKIJE EN DE ISLAM 


\section{CONCLUSIES}

De EU heeft zich gecommitteerd aan een beoordeling van het lidmaatschap van Turkije volgens dezelfde procedure als is en wordt toegepast bij de andere kandidaat-lidstaten. Bij deze beoordeling speelt de factor religie maar een beperkte rol, terwijl juist hierover veel onrust is ontstaan. Met dit rapport en de bijgevoegde verkenning poogt de WRR daarom bij te dragen aan een verdieping van het inzicht in de kenmerken van de Turkse islam en de historische achtergrond van de relatie met de Turkse staat.

De vraag die de raad zich in dit rapport heeft gesteld, is of het feit dat Turkije een land is met een bevolking die in meerderheid moslim is, een belemmering vormt voor de toetreding van dat land tot de EU. De raad beantwoordt deze vraag ontkennend. Aan de hiervoor beschreven historische ontwikkelingen, huidige karakteristieken van Turkije en de Turkse islam zijn volgens de raad geen argumenten te ontlenen voor de conclusie dat deze islam een obstakel zou vormen voor toetreding tot de EU. De raad concludeert dit mede in het licht van de zeer uiteenlopende wijze waarop de huidige lidstaten van de Unie formeel en feitelijk vorm geven aan de relatie tussen staat en religie.

Dat het bij Turkije gaat om een land met overwegend een moslimbevolking is wel degelijk een novum voor de EU. In de huidige lidstaten en de overige kandidaat-lidstaten is de christelijke religie immers de dominante godsdienst. Hierdoor is religie, lees: de islam, begrijpelijkerwijs een punt van discussie geworden. In zijn bijgaande verkenning wijzen Zürcher en Van der Linden op de paradox dat juist de lidstaten van de EU, met hun discours van scheiding van kerk en staat, in hun beoordeling van Turks lidmaatschap de inhoud van de religie laten meespelen. Hier speelt zeker ook mee dat de zorgen over Turkije worden beïnvloed door de algemene beeldvorming over de islam, waaronder de ervaringen met de opkomst van de politieke islam in moslimstaten en natuurlijk ook door de confrontaties in de recente tijd. Hierdoor is de perceptie gegroeid dat de wereld van de islam en het Westen elkaar moeilijk verdragen, en dat de kenmerken van de westerse democratische rechtsstaten vanuit islamitisch gezichtspunt worden afgewezen. Vanuit dat gezichtspunt zou het eerder moeten gaan om de staat te baseren op theocratie in plaats van op democratie, derhalve om het opheffen van de scheiding tussen religie en staat, om islamitisch recht in plaats van seculier recht, en niet om universele mensenrechten maar alleen die welke de islam voorstaat.

De islam kent evenals het christendom vele gezichten. Voor het christendom geldt dat er aanzienlijke verschillen zijn, zowel tussen als binnen landen en regio's, en dat de relatie ervan tot de ontwikkeling van de staat blijkens hoofdstuk 2 een van land tot land verschillend beeld vertoont. Met dat gegeven ten aanzien van het christendom is men in Europa wel vertrouwd, maar voor de islam geldt dat natuurlijk veel minder. Daarover wordt derhalve gemakkelijk in te generali- 
serende termen gedacht en gesproken. Die het christendom zo typerende pluriformiteit geldt evenwel ook voor de islam. De islam in Turkije kent geheel eigen karakteristieken en ook de grote pluraliteit ervan is sterk bepaald door de Turkse geschiedenis en context. Dit geldt evengoed voor de politieke manifestaties van de islam in Turkije.

Daarbij laat de Turkse geschiedenis in een aantal opzichten een opvallend grote parallellie zien met de West-Europese geschiedenis. Ten aanzien van de scheiding tussen het geestelijk en wereldlijk domein, de ontwikkeling van de seculiere rechtsstaat en de vroege manifestaties van democratie toont de historie zelfs een aanzienlijke gelijktijdigheid. Bij de constitutionele en rechtsstatelijke ontwikkeling heeft Turkije zich al zeer lang op Europa gericht, zelfs al ver voor de vestiging van de Republiek. Deze historische gang geeft aan dat voor de EU belangrijke waarden en instituties een hoge mate van geworteldheid in de Turkse samenleving kennen. Zoals uit het voorgaande bleek, worden de principes van de democratische rechtsstaat ook gedeeld door de hoofdstroom van het islamitisch politieke denken in Turkije dat zich vanaf de jaren zestig heeft doen gelden. Deze situatie rechtvaardigt derhalve niet Turkije te zien als een land dat geen deel zou hebben aan het cultuurgoed waarop de EU is gebaseerd. Het huidige Turkije wordt gekenmerkt door een staatsbestel waarover de islam geen zeggenschap heeft; eerder is sprake van het tegendeel. De vrijheid van godsdienst vormt dan ook een belangrijke wenselijkheid van islamitische politieke partijen. Het recht en het rechtsstelsel zijn gebaseerd op dezelfde seculiere principes als gelden in de Europese lidstaten; dit geldt ook voor het familierecht.

Zoals bleek in hoofdstuk 3 , heeft Turkije onmiskenbaar periodes gekend van ernstige polarisatie tussen staatsapparaat enerzijds en samenleving anderzijds. De twee meest gevoelige vraagstukken betroffen steeds de Koerdische onafhankelijkheid en de maatschappelijke en politieke rol van de islam. Deze territoriale en religieuze gevoeligheden zijn niet verwonderlijk, gezien de eeuwen van inkrimping en de transformatie van het islamitische Osmaanse rijk naar de seculiere Republiek Turkije. Wel verwonderlijk is dat het land deze enorme gebiedsreductie en karakterverandering doorstond zonder in het vaarwater te raken van omvangrijk moslimextremisme en zonder zijn dominante gerichtheid op Europa te verliezen. Daardoor heeft het inmiddels een redelijk functionerende democratie. De wereldwijde opleving van het islamitisch activisme in de jaren zeventig en tachtig heeft het land weliswaar niet onberoerd gelaten, maar toch niet van zijn pro-EU- en democratiseringskoers afgebracht. Integendeel zelfs: het is een islamitische politieke beweging die deze koers ook krachtig omarmt.

Zoals iedere kandidaat-lidstaat kent ook Turkije problemen. Zo blijkt de kemalistische staatsfilosofie, die de politieke islam als een anomalie ziet, tot op heden door het staatsapparaat te worden gekoesterd en krachtdadig bewaakt. Vanuit het perspectief van de Unie vormt deze staatsgerichtheid tot nu toe een groter probleem dan de manifestaties van de politieke islam. Het koesteren van de sterke staat heeft een volwaardige democratisering van de samenleving in de weg 
gestaan; er bestaat in Turkije ontegenzeggelijk een vorm van geleide democratie. Het staatstoezicht op het politieke proces getuigt nog immer van een angst voor de islam als een politieke factor, en heeft de uitingsvormen gebonden aan strakke grenzen.

Deze rol van de staat en vooral van het leger is voor een lidstaat van de EU vanzelfsprekend niet acceptabel. Zowel Europese Commissie als Parlement eist dan ook terecht dat het leger onder civiele controle komt, zoals ze dat ook verlangden van de Midden- en Oost-Europese landen. De recente ontwikkelingen zijn veelbelovend. De nu onder invloed van het toetredingsperspectief ondernomen hervormingsprogramma's en de voornemens voor wijziging van de grondwet hebben deze strekking. Toch dient volgens de raad de vraag onder ogen te worden gezien wat de gevolgen kunnen zijn voor het democratisch proces van een normalisering van de betrekkingen tussen het leger en het civiele bestuur. Zou het zich terugtrekken van deze 'bewaker' van het seculiere staatsbestel en de seculiere rechtsstaat tot een zodanige opkomst van het moslimfundamentalisme kunnen leiden dat deze verworvenheden in het geding komen? En wat als Turkije dan al lid zou zijn van de EU?

Een lange voorgeschiedenis zegt iets over de verankering en dientengevolge de stabiliteit van de huidige democratische en rechtsstatelijke instituties. Het zou evenwel van historicisme getuigen hieraan vervolgens zekerheid te willen ontlenen over de toekomstige ontwikkeling. Dat iets lang bestaat, wil immers nog niet zeggen dat het ook in stand blijft. Maar met deze kanttekening kunnen toch wel enkele verwachtingen worden beredeneerd.

In de eerste plaats lijkt volgens de raad de kans op aantasting van de democratische rechtsstaat beperkt door de brede aanhang onder de bevolking voor het lidmaatschap van de Unie, de afkeer van religieuze intolerantie en de in het vorige hoofdstuk beschreven sociologische processen die aan de politieke islam ten grondslag liggen. Zoals paragraaf 3.6 liet zien, heeft het electoraat regelmatig een voorkeur getoond voor gematigde partijen en lijkt het een meer radicaal-islamitische fase, waarvoor de aanhang nooit groot was, al achter zich te hebben gelaten. De zuiverende werking van democratie geldt evengoed voor Turkije als voor andere landen. Ook sociologisch gezien is de voorkeur voor matiging niet slechts een uitdrukking van ideeën maar ook van belangen; de aanzienlijke middenstand heeft een groot economisch belang bij toetreding tot de EU. Evenzo zien de aanhangers van een grotere godsdienstvrijheid in de Unie een belangrijke bescherming daarvan.

In de tweede plaats kan het (perspectief op het) lidmaatschap van de Unie zelf mitigerend werken op de spanningen binnen de Turkse samenleving. De inzet van het leger is sinds 1961 steeds geweest het bewaken van de veiligheid in Turkije; het zag politieke manifestaties van de islam nogal eens als bedreigend hiervoor. Christen-democratische partijen zijn een normaal verschijnsel binnen het politieke landschap van de lidstaten en dit zou ook moeten gelden voor isla- 
mitisch-democratische partijen. Integratie in een seculiere Unie, die zich heeft gecommitteerd aan het waarborgen van rechten en vrijheden en dat bij aanvaarding van de constitutie in versterkte mate zal doen, zal binnen Turkije de acceptatie van en ruimte voor islamitische partijvorming ten goede komen. Door de socialisering die uitgaat van het deelnemen aan de spelregels die gelden in de vele gremia van de EU zal de rol van het Turkse leger op zichzelf al worden teruggedrongen.

Het is evenwel zeker niet denkbeeldig dat naarmate de greep van het leger op het democratisch en bestuurlijk proces geleidelijk verzwakt en het staatsapparaat de islam meer ruimte geeft, er aanvankelijk een zekere turbulentie ontstaat. In Midden- en Oost-Europese landen ging de overigens veel onverwachtere overstap naar democratie eveneens gepaard met aanvankelijke radicalisering. Hierbij dient ook bedacht te worden dat de gang naar de EU in een aantal opzichten het inleveren van soevereiniteit betekent. Dit kan nationalistisch-politieke oriëntaties in de kaart spelen. Daar staat echter tegenover dat een vergrote ontplooiingsruimte voor de maatschappij niet alleen traditionele en nationalistische krachten kan mobiliseren, maar ook liberaal-islamitische (tegen)krachten. Want ook deze zijn door de conservatief getinte staatsislam naar de achtergrond gedrukt. Anders gezegd: door via die staatsislam de moskeeën te houden aan een conservatiefnationalistische lijn is de ontwikkeling naar een meer liberale islam vertraagd en is in elk geval een open religieus-maatschappelijke dialoog geblokkeerd geweest.

Een opbloeiende pluraliteit, in eerste instantie gepaard gaand met een aanzienlijke heftigheid in debat, hoeft echter niet negatief beoordeeld te worden. Het moet eerder worden gezien als een noodzakelijke voorwaarde om een betere balans tussen staat, religie en maatschappij te bewerkstelligen. Zo heeft de huidige regering, gesteund door de vrouwenbeweging, de aanval geopend op de formele en feitelijke achterstelling van vrouwen en meisjes, en de nog veelvuldig voorkomende geweldsuitoefening tegen hen. Dit onderwerp is tot op heden sterk getaboeïseerd, mede doordat de betrokkenen de betreffende traditionele gedragswijzen rechtvaardigen met een beroep op de islam. Het betreft hier overigens tradities die niet beperkt zijn tot moslims; ze komen ook voor in christelijke mediterrane landen (AIV 1999: 14). Wanneer de wetgeving en de implementatie ervan voldoen aan het EVRM heeft de EU additioneel weinig mogelijkheden om de Turkse staat aan te spreken op deze kwalijke praktijken. Des te belangrijker is het wanneer in Turkije zelf het islamitische gehalte van de bewuste praktijken onderwerp van debat gaan vormen en - zoals nu - moslims zelf zich ertegen teweer gaan stellen. Degenen die menen dat de islam tot deze praktijken gebiedt, zullen uiteraard ook het woord nemen. Dat is belangrijk. Waar immers de Unie onbevoegd is uit te maken wat al dan niet islamitisch is, kan het beëindigen van deze cultuurelementen - met ondersteuning van het recht - alleen uit eigen kring komen. Noch Turkije noch de lidstaten die met vergelijkbare gewoontes worden geconfronteerd, mogen de illusie hebben dat dergelijke praktijken in korte tijd ongedaan kunnen worden gemaakt. Voor de lidstaten en de Turkse minderheden in die staten is het bijzonder belangrijk 
wanneer uit Turkije zelf duidelijke signalen komen, van de zijde van de regering zowel als vanuit gezaghebbende islamitische kring, dat dergelijke gedragspatronen alles met discriminatie en criminaliteit van doen hebben, en niet inherent zijn aan de islam. Dat het taboe op het debat hierover nu in Turkije is doorbroken, is een gunstige ontwikkeling. Verdere democratisering zal vergelijkbare effecten hebben voor andere onderwerpen die nu nog in de taboesfeer liggen.

Zo zijn er verschillende redenen voor de verwachting dat de seculiere democratische rechtsstaat in Turkije bij een terugtred van de zelfverklaarde 'hoeders' hiervan niet in de gevarenzone zal komen, zij het dat in eerste instantie de geleidelijk groter wordende vrijheid een veel breder scala van oriëntaties en grotere tegenstellingen zal opleveren dan bij de huidige geleide democratie. De periode van het openen van de toetredingsonderhandelingen tot de feitelijke toetreding, die nog vele jaren zal duren, biedt Turkije evenwel de mogelijkheid om geleidelijk verder te wennen aan de Europese praktijken. Als het lidmaatschap eenmaal een feit is, is niet uit te sluiten dat zich situaties voordoen die bedreigend zijn voor de democratische rechtsstaat, zoals een hernieuwde staatsgreep. Dit gevaar geldt overigens niet alleen voor Turkije. Met het grote aantal aanstaande nieuwe lidstaten die nog maar kort naar een democratie zijn overgegaan, is dit gevaar zeker niet kleiner geworden. Zoals aangegeven in hoofdstuk 2, heeft de Unie bij eerdere conflicten getoond in staat te zijn tot het formuleren van spelregels hiervoor en nieuwe soorten conflicten kunnen daar opnieuw toe nopen. De eerder overeengekomen procedure geldt in het geval van een "duidelijk gevaar voor een ernstige schending door een lidstaat van de in art. 6 lid i genoemde beginselen" (zie hoofdstuk 2). Voor het geval ontwikkelingen in Turkije sterke anti-EUkrachten aan de regering zouden brengen, voorziet de conceptgrondwet van de Unie in de mogelijkheid van vrijwillige terugtrekking (art. 59).

Deze aangegeven gedragsmogelijkheden voor situaties waarin de wegen van Turkije en de EU in principiële zin tijdelijk of structureel divergeren, beschouwt de raad uiteraard niet als gerede mogelijkheden. Niettemin verkleinen ze over en weer het afbreukrisico van eenmaal genomen beslissingen.

Ook op basis van deze meer toekomstgerichte overwegingen meent de raad dat er geen grond is voor de veronderstelling dat de Turkse islam een belemmering vormt voor toetreding. Hij beveelt de regering dan ook aan dit standpunt, zo ze dit deelt, in buitenland en binnenland actief uit te dragen. 
DE EUROPESE UNIE, TURKIJE EN DE ISLAM 


\section{VOORUITBLIK}

In de beschreven karakteristieken van de Turkse islam ligt volgens de raad derhalve als zodanig geen belemmering voor toetreding tot de EU. En als het uiteindelijk tot een Turkse toetreding komt? Is het lidmaatschap van dit moslimland ook relevant voor de relatie tussen het Westen en de moslimwereld? Deze relatie is immers juist de laatste jaren door onder meer de spiraal van islamitische terreur en de aanvallen op Afghanistan en Irak erg problematisch geworden. Kan de Turkse toetreding de vrees temperen voor een onvermijdelijke 'botsing der beschavingen'?

Uiteraard mag daarin niet de eerste reden liggen om Turkije toe te laten tot de EU; die kwestie moet op eigen merites worden beoordeeld, met als maatstaf het goed kunnen functioneren van de Unie als waarden- en handelingsverbond. Bij het verwateren van de kracht van de Unie is immers niemand gebaat. Maar als zou blijken dat de Turkse toetreding niet langer op overwegende bezwaren zou stuiten, dan wordt die vraag wel van belang. Voor regeringen die in de huidige situatie te maken hebben met weerstand van hun bevolkingen tegen een Turks lidmaatschap, zou hierin wel degelijk een belangrijk additioneel argument kunnen liggen. De EU is niet uitsluitend gebaat bij het instandhouden van interne legitimiteit en effectiviteit; ze heeft groot belang bij externe vreedzame verhoudingen aangezien ze zich nu eenmaal niet kan afsluiten van de wereld. $\mathrm{Nu}$ de bevolkingssamenstelling van de Eu bovendien steeds meer een afspiegeling gaat vormen van de wereldbevolking, zijn ook de interne verhoudingen niet langer immuun voor conflictueuze verhoudingen elders.

Zoals in hoofdstuk 2 werd aangegeven, ligt de historische ratio van het Europese integratieproject niet in het creëren van een verband tussen naties met gelijkluidende identiteit en cultuur of gelijke waarden en normen. Evenmin betrof het een project tussen staten met een onderling vreedzame geschiedenis. Het ging er aanvankelijk juist om, via een bovenstatelijk verband en economische integratie, een einde te maken aan een geschiedenis van conflict tussen landen die ook qua identiteit, cultuur, waarden en normen grote verschillen vertoonden. In de huidige context met de bestaande animositeit is derhalve de vraag alleszins gerechvaardigd of het Europese integratieproject opnieuw een conflictdempende rol kan spelen.

In de huidige wereldverhoudingen zijn de relaties tussen het Westen en de wereld van de islam ontegenzeggelijk problematisch. In de vroege jaren negentig beredeneerde Samuel Huntington (1993) al dat na de Koude Oorlog de nieuwe conflicten met name tussen deze twee beschavingen zouden plaatsvinden. Deze 'botsing tussen beschavingen' is sindsdien als karakterisering van de verhouding tussen de wereld van de islam en het Westen door velen - daar en hier - aanvaard, en de aanslagen van 11 september 2001 en de hierop gevolgde oorlogen en nieuwe aanslagen lijken de juistheid ervan te bevestigen. Zoals gesteld in hoofdstuk 1 zijn de recent gerezen aarzelingen in de lidstaten rond de Europese kandidatuur van Turkije hierop deels ook terug te voeren. 
Volgens Zürcher en Van der Linden is de toetreding van Turkije een hoopgevend signaal voor de islamitische wereld dat het Westen niet - zoals velen daar denken en vrezen - uitgaat van het paradigma 'botsing tussen beschavingen', en dat de westerse verworvenheden ook in een moslimland een plek kunnen krijgen. De WRR deelt deze mening; meer in het algemeen geeft het Turkse lidmaatschap aan dat beide werelden elkaar niet uitsluiten. Wanneer Turkije deel uitmaakt van de Unie wordt in ieder geval voorkomen dat het beeld zich kan vastzetten van twee geografisch onderscheiden religieus te interpreteren beschavingsblokken. Daarmee zou tenminste één voorwaarde voor instandhouding van het clash-paradigma vervallen. Dat het concept van sterk uiteenlopende beschavingsblokken ook historisch en cultureel onhoudbaar is, tonen Zürcher en Van der Linden overtuigend aan. Feitelijk is er veel meer gelijkluidendheid en gelijktijdigheid van de ontwikkelingen tussen Turkije en Europese lidstaten dan Huntingtons concept suggereert. Ook de grote aantallen moslims in Europese lidstaten impliceren dat de Europese identiteit en beschaving niet meer kunnen worden gedefinieerd in louter westerse termen, zo dit ooit al mogelijk zou zijn geweest. Wanneer Turkije op religieuze grond het lidmaatschap van de Unie zou worden onthouden, zou het signaal aan deze moslims zijn dat zij feitelijk alleen thuishoren in Europa bij volledige assimilatie. Toetreding zou echter onderstrepen dat ook zij voluit deel uit maken van de Unie.

Dat Turkije als lid van de Unie als model kan functioneren voor andere moslimlanden, is echter veel twijfelachtiger. De in Turkije bestaande arrangementen zijn bepaald door heel specifieke historische factoren die elders in de moslimwereld ontbreken. Bovendien zou de perceptie in de Arabische wereld van Turkije als vroegere kolonisator en huidige handlanger van het Westen, onder andere tot uiting komend in de Turkse steun voor Israël, dit in de weg staan. Taspinar (2003) beschrijft de Turkse situatie dan ook als sui generis in plaats van als model. Hij wijst op het autoritaire karakter van het kemalisme en de rol van het leger, waardoor nog niet gesproken kan worden van een volwaardige liberale democratie. De ervaringen in Turkije zullen door historische factoren en de beschreven eigenschappen als zodanig geen navolging krijgen, maar invloed is er wellicht wel op algemener niveau. In een dynamisch perspectief zou Turkije wel degelijk inspiratie kunnen vormen voor andere staten doordat het aantoont dat islam en democratie niet op gespannen voet behoeven te staan. Inbedding in de EU zal de verankering van de democratie ten goede komen evenals de bescherming van rechten en vrijheden. Bovendien wordt ook de druk in de Arabische wereld groter in de richting van democratisering en meer respect voor mensenrechten. De twee inmiddels verschenen Arab Human Development Reports van het United Nations Development Programme (2002 en 2003) alsook '11 september' en de hierop gevolgde oorlogen, hebben de interne aandrang in dit opzicht versterkt. Voor veel regeringen van moslimlanden vormt het islamitisch extremisme een nachtmerrie, waardoor grote angst bestaat voor democratisering en meer rechtsstatelijke bescherming van de burger tegen de staat. 
De inmiddels relatief grote toegankelijkheid van het Turkse politieke systeem voor de verschillende expressies van de politieke islam heeft het land behoed voor de mate van extremisme die elders voorkwam. De democratie is niet met een big bang ingevoerd, maar geleidelijk en zeker niet zonder argwanende 'begeleiding' door het leger. Hoe men ook over die rol moge denken en hoe hardhandig die ook werd uitgeoefend, het leger heeft zich kort na ingrijpen wel altijd weer snel in de kazernes teruggetrokken. Ook hiermee onderscheidt de Turkse ontwikkeling zich van vele andere moslimlanden (Taspinar 2003). In een rapport van de Britse parlementaire commissie voor buitenlandse zaken over toetreding van Turkije tot de EU wordt gewezen op de bijzondere positie van het Turkse leger. Dit heeft namelijk sinds 1961 wettelijk als taak de veiligheid van Turkije ook tegen binnenlandse vijanden te beschermen. Als zodanig geniet het ook groot vertrouwen van de bevolking. Is de rol die het leger speelt bij het markeren en controleren van de grenzen van het democratisch proces derhalve niet alleen maar negatief, naar het oordeel van deze Britse commissie overschat het leger de gevaren voor stabiliteit en de seculiere staat die uitgaan van de politieke islam. Hoewel de positie van het Turkse leger voor een lidstaat onaanvaardbaar is, bepleit de commissie met het oog op toetreding wel de grondwettelijke en maatschappelijke positie ervan serieus te nemen en geleidelijk toe te werken naar het plaatsen van het leger onder civiel toezicht (House of Commons 2001). Ten aanzien van democratisering wijst ook Zakaria op het belang van geleidelijkheid. Liberale democratieën ontstaan niet op afroep; de ervaring is dat bij te snelle invoering de kans op onliberale democratieën groot is. In zijn ogen dient constitutioneel liberalisme - scheiding van machten, rechtsstatelijkheid, bescherming van basisvrijheden aan democratie vooraf te gaan: als macht niet eerst gebonden is, kan de uitoefening ervan ontaarden in tirannie, hoe democratisch de machtspositie ook is verkregen (Zakaria 1997). Veel moslimstaten zullen door interne en/of externe druk de weg naar verdere democratisering moeten opgaan, zonder het risico te willen lopen dat Zakaria schetst. Met inachtneming van de veel minder stabiele situatie in deze landen, zijn de Turkse ervaringen, waarbij het leger de greep op de samenleving geleidelijk aan moet loslaten, voor hen zeer instructief.

Het Turkse blazoen ten aanzien van mensenrechten en vrijheden is bepaald niet ongeschonden. Het autoritaire secularisme kan volgens Graham Fuller (2003) dan ook zeker niet als model aan andere landen worden voorgehouden. Maar Turkije laat wel zien dat desondanks geleidelijk plaats is geboden aan politieke partijen die recht doen aan de eigen islamitische tradities en de zich ontwikkelende democratische gezindheid van de bevolking. Deze Turkse ontwikkeling is gepaard gegaan met vallen en opstaan, en heeft uiteindelijk - ook gestimuleerd door het vooruitzicht op lidmaatschap en hiermee samenhangende interventies van de EU - toch een leerproces opgeleverd over hoe seculiere staat, democratie en politieke islam binnen een constitutionele raamwerk met elkaar in overeenstemming kunnen worden gebracht. Zij kan voor landen die dit pad op willen een aanmoediging vormen zelf te experimenteren met rechtsstatelijkheid en democratisering. Turkije biedt hun geen model, maar het vormt wel een laboratorium waarin voor andere landen interessante experimenten plaatsvinden (Yavuz 2003:7). 
In veel moslimlanden bestaan foutieve percepties van het Westen, evenals omgekeerd. Beelden omtrent bijvoorbeeld de betekenis van westers secularisme, dat nogal eens wordt geïnterpreteerd als vijandigheid van de staat ten opzichte van godsdienst in het algemeen en islam in het bijzonder, of ten opzichte van gelovigheid als zodanig, of gelijkgesteld wordt met nihilisme, immoraliteit en losbandigheid, lenen zich evengoed voor correctie als die in het Westen omtrent de achterlijkheid van de islam, het antidemocratische en intolerante karakter van de aanhangers van deze religie. De 'ontdekking' door islamitische partijen in Turkije dat de EU juist garanties biedt voor hun bewegingsvrijheid vormt een belangrijke correctie op het eerdere beeld. Een Turkije dat als lid van de Unie betrokken is bij de debatten en de veelheid van opvattingen en zorgen die er bestaan, en dat bovendien vanzelfsprekend is ingevoerd in het 'islamitisch idioom', kan in dit opzicht zeker een brugfunctie vervullen. Hierdoor kan toch het over en weer bestaande beeld van onverenigbaarheid en 'botsing' op indirecte wijze worden gemitigeerd. Gegeven de eerdere conclusie dat de kenmerken van de Turkse islam toetreding van Turkije tot de EU niet in de weg staan, kan lidmaatschap matigend werken op de inmiddels gegroeide tegenstellingen en perceptie daarvan tussen het Westen en de wereld van de islam. De WRR zal op deze thematiek terugkomen in een apart Rapport aan de Regering. 


\section{LITERATUUR}

Adviesraad Internationale Vraagstukken (1999) Naar rustiger vaarwater. Een advies over de betrekkingen tussen Turkije en de Europese Unie, 9 juli.

AK Parti (1999) Development and Democratization. Program. http://www.akparti.org.tr/programeng3.asp

Bader, V. (2003a) 'Religious diversity and democratic institutional pluralism', Political Theory, 31, 2, 265-294.

Bader, V. (2003b) 'Religions and states. A new typology and a plea for non-constitutional pluralism', Ethical Theory and Moral Practice 6, 55-91.

Bielefeldt, H. (200o) Moslims in de lekenstaat. Het recht van moslims mee vorm te geven aan de Europese samenleving, deel I en II. http://www.flwi.ugent.be/cie/CIE/ bielefeldtı_a.htm\#noot.

Çarkoğlu, A., en B. Toprak (200o) Religion, Society and Politics in Turkey, 20oo. Summary report of survey results.

Economist, The 'Turkish women. Thou shalt not kill', 21 February 2004.

Erdogan, M. (1999) 'Islam in Turkish Politics. Turkey’s Quest for Democracy without Islam', Critique, 15, 25-50.

Europese Commissie (2002) Candidate Countries Eurobarometer 2002, First Results,

Directoraat-generaal Pers en communicatie, http://europa.eu.int/comm/ public_opinion/archives/cceb/2002/cceb_2002_highlights_en.pdf.

Europese Commissie (2003) Regular Report on Turkey's progress towards accession 2003, Brussels.

Europese Conventie (2003) Ontwerp verdrag tot vaststelling van een grondwet voor Europa, Luxemburg: Europese Gemeenschappen.

Europees Parlement (2003) Verslag over de aanvraag van Turkije inzake toetreding tot de Europese Unie, Commissie buitenlandse zaken, mensenrechten, gemeenschappelijke veiligheid en defensiebeleid, (COM(2002) 700- $\mathrm{C}_{5}-0104 / 2000-2000 /$ 2014(COS)) A5-0160/2003, 20 mei.

Europocket. Verdragsteksten EG-Europese Unie c.a. inclusief 'Nice' (2002), Deventer: Kluwer.

Ferrari, S. (2002) 'Islam and the Western European Model of Church and State Relations', 6-19 in: W.A. Shadid \& P.S. van Koningsveld (eds.), Religious Freedom and the Neutrality of the State: the Position of Islam and the European Union, Leuven: Peeters.

Fuller, G. E. (2003) The Future of Political Islam, New York: Palgrave Macmillan.

Goff, J. le en R. Rémond (1992) Histoire de la France religieuse, Tome IV, Parijs: Seuil.

Göle, N. (1996) The Forbidden Modern. Civilization and Veiling, Ann Arbor: The University of Michigan Press.

House of Commons (2001) Turkey, Select Committee on Foreign Affairs, Sixth report, http://www.publications.parliament.uk/pa/cm200102/cmselect/cmfaff/6o6/ 6o6o3.htm

Huntington, S. (1993) 'The Clash of Civilizations?’, Foreign Affairs, 72, 3, 22-49.

Huntington, S. (1996) The Clash of Civilizations and the Remaking of the World Order, New York: Simon and Schuster. 
International Herald Tribune, 'The long bloody path that led to French secularism', 7 January 2004.

Jubilee Campaign (2003) Religious Freedom in new and future EU member-states. Law and practice, http://www.forumi8.org/PDF/EUaccession.pdf

Koçak, M. (2004) 'The Clash of Civilizations': Turkey (najaar te verschijnen).

Madeley, J. (2003) 'A Framework for the Comparative Analysis of Church-State Relations in Europe: North and South, East and West' in: idem (ed.), Religion and Politics: Europe, Ashgate: Dartmouth Press.

Madeley, J. (te verschijnen) 'European Liberal Democracy and the Principle of State Religious Neutrality' in: Z. Enyedi \& J. Madeley (eds.), Church and State in Contemporary Europe: The Chimera of Neutrality, Londen: Frank Cass.

Massignon, B. (2003) Regulation of religious diversity by the institutions of the European Union: from confrontation of national exceptions to the emergence of a European model.http://hirr.hartsem.edu/sociology/sociology_online_articles_massignon. html

McCormick, J. (2002) Understanding the European Union. A concise introduction, Londen: MacMillan.

Monde, Le 'Document. Le rapport de la Commission Stasi sur la Laïcité', 12 décembre 2003. Zie ook: http://www.laic.info/Members/webmestre/Folder.2003-o911.4517/rapport-stasi.pdf

NRC Handelsblad, 'EU moet hard zijn voor Turkije', 11 februari 2004.

Rouvoet, A. (2003) Scheiding van kerk en staat is geen scheiding van geloof en politiek. http://www.tweedekamer.christenunie.nl/nieuws.php?tekstId+=333

Sunier, T. (2004) 'Scheiding van kerk en staat?’, GroenLinks Magazine.

Taspinar, O. (2003) An Uneven Fit? The 'Turkish Model' and the Arab World, The Saban Center for Middle East Policy at the Brookings Institution, Analysis Paper 5, Washington D.C.

Toprak, B. (2001) Religion and the state in Turkey. http://www.dayan.org/mel/ toprak.pdf

Trouw 'Turkije niet aan het lijntje houden', 2 februari 2004.

United Nations Development Programme (2002) Arab Human Development Report 2002. Creating Opportunities for Future Generations, New York: UNDP.

United Nations Development Programme (2002) Arab Human Development Report 2003. Building a Knowledge Society, New York: UNDP.

U.S. Department of State, Bureau of Democracy, Human Rights, and Labor, International Religious Freedom Report 2002, http://www.state.gov/g/drl/rls/irf/2002/ 13986.htm

Waardenburg, J.D.J. (2001) Institutionele vormgevingen van de Islam in Nederland gezien in Europees perspectief, Werkdocumenten W118, Den Haag: WRR.

Wetenschappelijke Raad voor het Regeringsbeleid (2001) Naar een Europabrede Unie, Rapporten aan de Regering nr. 59, Den Haag: Sdu Uitgevers.

Wetenschappelijke Raad voor het Regeringsbeleid (2002) De toekomst van de nationale rechtsstaat, Rapporten aan de Regering nr. 63, Den Haag: Sdu Uitgevers.

Wetenschappelijke Raad voor het Regeringsbeleid (2003a) Slagvaardigheid in de Europabrede Unie, Rapporten aan de Regering nr. 65, Den Haag: Sdu Uitgevers. 
Wetenschappelijke Raad voor het Regeringsbeleid (2003b) Waarden, normen en de last van het gedrag, Amsterdam: Amsterdam University Press.

White, J.B. (2002) Islamist mobilization in Turkey. A study in vernacular politics, Seattle: University of Washington.

Yavuz, M.H. (2003) Islamic Political Identity in Turkey, Oxford: Oxford University Press.

Yesilkagit, K. (1997) 'Islamic Fundamentalism and the Role of the Turkish Military between 1980 and 1997', Jason, 5, 22, 8-13.

Zakaria, F. (1997) 'The Rise of Illiberal Democracy', Foreign Affairs, 76, 6, 22-43.

Zemni, S. (2002) 'Islam, European Identity and the Limits of Multiculturalism', 158-173 in: W.A. Shadid en P.S. van Koningsveld (eds.), Religious Freedom and the Neutrality of the State: the Position of Islam and the European Union, Leuven: Peeters. 
DE EUROPESE UNIE, TURKIJE EN DE ISLAM 


\section{Zoeken naar de breuklijn}

Een verkenning naar de rol van de Turkse islam in de toetreding van Turkije tot de Europese Unie in het licht van de 'Botsing der Beschavingen'

Erik-Jan Zürcher en Heleen van der Linden 
DE EUROPESE UNIE, TURKIJE EN DE ISLAM 


\section{INHOUDSOPGAVE}

I Inleiding: Turkije - breuklijn, frontlijn of proeftuin? 83

$2 \quad$ Het hedendaagse islamitische landschap van Turkije 89

$\begin{array}{lll}2.1 & \text { Islam en staat } & 89\end{array}$

2.1.1 Het '28 februari-proces': confrontatie tussen religie, maatschappij en staat $\quad 89$

2.1.2 Islam en staat bij de Osmanen 90

2.1.3 Secularisering in het Osmaanse rijk 93

2.1.4 Het kemalistische ideaal $\quad 98$

2.1.5 Twee interpretaties van secularisme 101

2.1.6 Islam in de politiek en de 'staatsislam' 102

2.1.7 Islamitische doorbraak en kemalistisch reveil 106

$\begin{array}{lll}2.2 & \text { Officiële doctrine versus tarikats en neo-bewegingen } & 108\end{array}$

2.2.1 Mystieke ordes en de actualiteit 108

$\begin{array}{ll}\text { 2.2.2 Islamitische mystiek } & 109\end{array}$

2.2.3 De tarikats en de Osmaanse staat $\quad 110$

2.2.4 De Nakşibendi-orde 111

2.2.5 Het kemalistische optreden tegen de ordes 112

2.2.6 Sait Nursî en de Nurcu-beweging 113

2.2.7 De Süleymancıs $\quad 115$

2.2.8 De Fethullahcılar $\quad 116$

2.2.9 Financiering van de ordes: stichtingen en verenigingen $\quad 117$

$\begin{array}{ll}2.3 & \text { Soennitische islam en alevitisme } \\ 118\end{array}$

2.3.1 De niet-soennitische stromingen 118

2.3.2 Wie zijn de alevieten? 118

2.3.3 Zijn de alevieten moslims? $\quad 120$

2.3.4 Alevieten en het kemalisme 122

2.3.5 De trek naar de stad 123

2.3.6 De herontdekking van het religieuze alevitisme $\quad 125$

$\begin{array}{lll}2.4 & \text { Islam, fundamentalisme en terrorisme } & 127\end{array}$

$\begin{array}{lll}2.4 .1 & \text { Terroristische aanslagen } & 127\end{array}$

2.4.2 Modernisme, fundamentalisme en traditionalisme $\quad 128$

$\begin{array}{lll}2.4 .3 & \text { IBDA-C } & 130\end{array}$

2.4.4 Hizbullah 131

2.4.5 Het Kalifaat van Keulen 132

$\begin{array}{lll}2.5 & \text { Christenen en joden in Turkije } & 133\end{array}$

2.5.1 Niet-moslims binnen de moslimgemeenschap 133

2.5.2 De 'mensen van het boek' 134

2.5.3 Buitenlanders en protégés 135

$\begin{array}{ll}2.5 .4 & 137\end{array}$

2.5.5 Niet-moslims tijdens de republiek 139

2.5.6 Is een Turk een moslim? 141 
3 De Turkse islam en de EU: Botsing der Beschavingen? 143

3.1 Modern versus westers 143

3.2 De positie van Turkije $\quad 145$

$\begin{array}{lll}3.3 & \text { Waarden als culturele erfenis } & 147\end{array}$

3.4 De Turkse islam, democratie en mensenrechten $\quad 148$

3.5 De positie van de officiële islam $\quad 152$

3.6 De stem van de oppositie $\quad 154$

3.7 Is er een voedingsbodem voor fundamentalisme?

3.8 Pluralisme als onderdeel van democratisering 160

3.9 De Turkse positie: niet 'dankzij de islam'en ook niet 'ondanks de islam' $\quad 162$

4 Conclusie: de Turkse islam en de Europese beschaving 165

$\begin{array}{ll}\text { Literatuur } & 167\end{array}$

$\begin{array}{lr}\text { Websites } & 170\end{array}$ 


\section{INLEIDING: TURKIJE - BREUKLIJN, FRONTLIJN OF PROEFTUIN?}

Sinds het midden van de jaren negentig is de discussie over een mogelijke toetreding van Turkije tot de Europese Unie (EU) niet alleen meer gevoerd aan de hand van criteria op het gebied van democratie en mensenrechten, veiligheid en economie. De drastische uitbreiding van de EU naar het oosten heeft met name Europese publicisten en politici aan het denken gezet over de fundamentele kenmerken van 'Europa' en over de vraag waar de grenzen van Europa liggen. Het spreekt bijna vanzelf dat deze discussies zich toegespitst hebben op de casus Turkije. Dit land heeft immers niet alleen als enige al meer dan veertig jaar officieel uitzicht op volledig lidmaatschap van de EEG/EG/EU, maar het is ook het land dat op het oog cultureel het meest afwijkend is.

Het afwijkende culturele karakter van Turkije wordt over het algemeen in de discussies verbonden aan het feit dat het land een bevolking heeft die voor meer dan 95 procent zegt moslim te zijn. Historisch speelt in de perceptie zeker een rol dat Turkije, of beter, het Osmaanse rijk, honderden jaren lang de enige islamitische grootmacht was waarmee Europa direct werd geconfronteerd.

Degenen die hun bedenkingen uiten over de opname van Turkije in de EU, en die dat op culturele of religieuze gronden doen, baseren zich expliciet of impliciet heel vaak op de ideeën van de Amerikaanse socioloog Samuel Huntington over de zogenaamde 'Botsing der Beschavingen' ('Clash of Civilizations'). In 1993 ontvouwde Huntington voor het eerst zijn ideeën over de 'Clash of Civilizations' in het Amerikaanse tijdschrift Foreign Affairs. Wat hij in dat artikel zei, en later in 1996 in een boek uitwerkte, kwam kort gezegd neer op het onderstaande.

Sinds het ontstaan van een systeem van internationale betrekkingen in de zestiende en zeventiende eeuw zijn er grofweg vier fasen in de geschiedenis te onderscheiden. De eerste duurde tot aan de Franse Revolutie. Internationale betrekkingen waren in deze eeuwen in essentie betrekkingen tussen vorsten. Dat veranderde met de Franse Revolutie in een systeem van betrekkingen tussen naties. Zowel in de eerste als in de tweede fase was het systeem veelpolig. Anders gezegd, er was een flink aantal min of meer gelijkwaardige spelers actief die samen het verloop van oorlog en vrede bepaalden. Na de Eerste Wereldoorlog komt er een einde aan dit systeem gebouwd op nationale staten. De opkomst van het communisme en iets later van fascisme en nationaal-socialisme markeert het begin van een internationaal systeem gebouwd op concurrerende ideologische blokken. Het einde van de Tweede Wereldoorlog betekent hiervan niet het einde, maar juist het begin van de meest ideologische fase in de geschiedenis van de internationale betrekkingen. Vijftig jaar lang bevriest de Koude Oorlog de wereld in een tweepolig systeem, waarbij de zogenaamde Derde Wereld het passieve strijdperk is waar 'Oost' en 'West' hun strijd om de wereldheerschappij (laten) uitvechten. 
Met de ineenstorting van het communisme is in Huntingtons ogen een fundamenteel nieuwe situatie ontstaan. De verhoudingen in de wereld worden niet langer bepaald door twee ideologische blokken, maar er is een terugkeer naar een veelpolig systeem opgebouwd uit nationale staten. Die staten - en dit is het kernidee van 'The Clash of Civilizations and the Remaking of World Order' laten zich in hun positiebepaling leiden door culturele factoren: solidariteit binnen het beschavingsgebied waartoe zij behoren en antagonisme jegens andere beschavingen. Huntington ziet een wereld voor zich, verdeeld in zeven grote beschavingsblokken (Chinees, Japans, hindoeïstisch, islamitisch, orthodox, westers en Latijns-Amerikaans) en hij verwacht dat de grote conflicten van de toekomst zich zullen afspelen in de periferie van die beschavingen en met name tussen 'het Westen', China en 'de islam'. In die grote wereldomspannende conflicten zullen niet de beschavingen zelf handelend optreden, zij hebben immers geen regering of leger, maar de dominante staten binnen iedere beschaving, zoals de Verenigde Staten, India of China, zullen zich in hun optreden door hun plaats in de eigen 'beschaving' laten leiden.

Inmiddels is 'Clash of Civilizations' een begrip geworden, niet alleen in de wereld van de wetenschap. Binnen de politieke wetenschappen en de moderne geschiedenis is er enorm veel gedebatteerd over Huntingtons these, maar over het algemeen zijn de reacties kritisch tot afwijzend geweest. Dat geldt zowel voor de empirische onderbouwing (Huntingtons feitenkennis is vaak dubieus) als de geesteshouding, door critici omschreven als 'intellectueel tribalisme'. Wat hem vooral voor de voeten wordt geworpen is dat hij op een onverantwoorde manier de suggestie wekt dat beschavingen monolieten zijn, in plaats van ingewikkelde mozaïeken. In werkelijkheid is het 'Westen' van George W. Bush natuurlijk iets anders dan dat van Woody Allen, om nog maar te zwijgen van de caleidoscoop die Europa heet.

Meer nog dan in de wetenschap hebben Huntingtons ideeën invloed gehad in de wereld van de politiek en het buitenlands beleid. In allerlei debatten spelen ze een rol, en vaak een problematische. Huntington nam klakkeloos het Chineesnationalistische idee over dat de fabelachtige opkomst van de Aziatische tijgereconomieën gebaseerd was op 'confucianistische waarden' - koren op de molen van autoritaire heersers zoals Mahathir in Maleisië en Lee in Singapore met hun pleidooi dat democratie en mensenrechten westerse uitvindingen zijn die niet passen bij 'Aziatische waarden'.

Voor Huntington is ook de EU een cultuurgemeenschap. Met de uitbreiding van de EU naar het oosten is in zijn ogen een oude culturele grens hersteld: die tussen het westerse en het oosterse christendom (waarbij hij voor het gemak maar aan de rol van Griekenland voorbijgaat). De ideeën die Huntington in 1993 in zijn artikel en in 1996 in zijn boek uiteenzette, beïnvloedden in Europa christen-democraten zoals Kohl en Martens en liberalen als Bolkestein en brachten hen ertoe Europa te definiëren als een cultuurgemeenschap, gebaseerd op christendom en humanisme. Dat bracht de logische conclusie met zich mee dat 
islamitische landen zoals kandidaat-lid Turkije niet in Europa thuishoorden, een conclusie die kortgeleden, in 2002, door de voorzitter van de Europese Conventie, Giscard d'Estaing nog maar eens is herhaald.

In Huntingtons wereldbeeld zijn het met name de Chinese beschaving en die van de islam die zich met eigen waardenstelsels ontwikkelen tot concurrenten voor de westerse liberale democratie. Daarbij omhelst hij een standpunt dat moslimfundamentalisten als muziek in de oren zou klinken: het standpunt dat de islamitische religie en cultuur niet te verenigen zijn met de 'westerse' beschaving, waaronder de liberale democratie.

Islam als antithese van de westerse beschaving? Vanuit dat gezichtspunt lijkt Turkije bij uitstek de proeftuin of, beter misschien, de frontlijn waar Huntingtons ideeën op hun waarde getoetst kunnen worden. Het land is de grootste moslimbuur van Europa, NAVO-lid, aspirant EU-lid en lid van de Raad van Europa en de OVSE. Het is ook een land met een bevolking waarvan meer dan 95 procent zegt moslim te zijn en dat de directe erfgenaam van het Osmaanse rijk is. De Osmaanse sultans waren eeuwenlang de belangrijkste tegenspelers van het christelijke Europa. Vierhonderd jaar lang beheersten zij het Midden-Oosten en Zuidoost-Europa en waren zij de enige islamitische vorsten die aanspraak konden maken op de titel 'Beschermer van de Heilige Plaatsen' (Mekka en Medina).

In deze verkenning willen we nagaan in hoeverre de wijdverbreide perceptie dat er een culturele breuklijn ligt tussen Turkije en Europa en dat het de religieuze dimensie is die deze breuklijn zijn potentieel verwoestende werking geeft, juist is. Met andere woorden, maakt het feit dat Turkije een islamitisch land is, of tenminste een land van voornamelijk moslims, het land een zodanig vreemde eend in de bijt dat het beter niet in de EU kan worden opgenomen? Het onderzoeken van deze vraag betekent natuurlijk het aan de orde stellen van de vraag of het denken in beschavingsblokken, zoals Huntington dat populair heeft gemaakt, zinvol of vruchtbaar is. Is er werkelijk sprake van 'het Westen' en 'de islam'? En is de scheidslijn tussen die twee 'blokken' werkelijk een frontlijn? Of kunnen we juist in Turkije de omtrek ontwaren van een symbiose van westerse en islamitische cultuurelementen?

Voor de behandeling van de hier gestelde vraag hebben we de volgende opzet gekozen. Eerst zullen we in het eerste deel (hfdst. 2) proberen een beschrijving te geven van de belangrijkste aspecten van de hedendaagse Turkse islam. Hierbij is het de bedoeling de Turkse islam in kaart te brengen op een manier die zowel de belangrijkste eigenschappen van juist de Turkse islam weergeeft als ook de veelvormigheid van het religieuze leven in Turkije. De doelstelling is niet om een algemene discussie te voeren over 'de islam', maar de islam juist te lokaliseren en te historiseren. Anders gezegd, te beschrijven wat nu typisch is voor de Turkse islam en hoe deze geworden is tot wat hij is. 
Op deze plaats moet wel benadrukt worden dat het natuurlijk onmogelijk is om een verschijnsel als 'de islam' of zelfs maar 'de Turkse islam' op een manier te beschrijven die een pretentie van volledigheid kan hebben. De islam is zowel een doctrinair, zo men wil, een ideologisch systeem dat op alle grote vragen een antwoord wil geven en een richtsnoer biedt voor het ideale menselijke leven, alsook een maatschappelijk verschijnsel met een enorme schakering aan concrete verschijningsvormen.

Daarnaast is het ook niet gemakkelijk om aan te geven wat nog als deel van 'de islam' beschouwd moet worden en wat niet. Culturele codes, gewoonten en tradities die op zich niets met het doctrinaire systeem van de islam te maken hebben, zoals het gearrangeerde huwelijk, eerwraak of sluiering, worden door de buitenwereld, met name in het Westen, vaak juist als kenmerkend voor de islam beschouwd. Traditionele bevolkingsgroepen die zich sterk maken voor de handhaving van dit soort tradities, sacraliseren deze van hun kant en zien de tradities als hoekstenen van hun geloof. Dit rapport gaat met name over de positie van de islam als doctrinair systeem in de Turkse maatschappij, al zijn er natuurlijk raakvlakken tussen de ideologie aan de ene kant en de culturele codes aan de andere, zoals bijvoorbeeld bij het verbod op het dragen van hoofddoekjes in het onderwijs, een van de frontlijnen van de politieke strijd in Turkije.

We hebben ervoor gekozen om in het eerste deel vijf aspecten van de Turkse islam te behandelen, omdat die de belangrijkste rol spelen en daarmee een goed fundament vormen voor het beantwoorden van de vraag in hoeverre in Turkije de typische kenmerken van de Europese waardengemeenschap, zoals democratie en mensenrechten, een symbiose zijn aangegaan, of nog kunnen aangaan, met een islamitische culturele erfenis. De onderwerpen die aan bod komen, zijn: de verhouding tussen islam en staat; de officiële doctrine versus tarikats en neobewegingen; soennitische islam en alevitisme; islamitisch fundamentalisme en de positie van niet-moslims.

Op basis van deze inventarisatie willen we in het tweede deel (hfdst. 3 ) terugkeren naar de centrale probleemstelling. Dit door middel van het presenteren van deelvragen die met name belangrijk zijn voor de vraag naar de inpasbaarheid van Turkije in de EU. Bijvoorbeeld de vraag in hoeverre Turkije deel heeft aan een gemeenschappelijke Europese culturele erfenis. En of de Turkse islam wel of niet compatibel is met in Europa gegroeide ideeën over democratie en mensenrechten. Of: hoezeer worden het wereldbeeld en de leefwijze van de Turken eigenlijk door hun religie bepaald en wat zijn de kansen op, of risico's van een overwinning van islamitisch fundamentalisme? Een deel van de antwoorden op deze vragen zullen we baseren op kernteksten van de verschillende in hoofdstuk 2 beschreven verschijningsvormen van de Turkse islam. Teksten als de zakcatechismus van de zogenaamde 'staatsislam', een publicatie van Necmettin Erbakan, het partijprogramma van de AK-partij en een toespraak van een vooraanstaand modernist. We bekijken in hoeverre de uitspraken in de betreffende teksten in tegenspraak zijn met kernwaarden die aan de 'westerse beschaving', en in dit 
geval de EU worden toegeschreven. Op basis van deze vergelijkingen, maar ook bijvoorbeeld naar aanleiding van een onderzoek naar religieuze attitudes van de Turkse bevolking proberen we meer inzicht te verschaffen in de Turkse bodemgesteldheid met betrekking tot islamitisch fundamentalisme. Uitgaande van de veronderstelling dat pluriformiteit, onder meer op het gebied van religie en media, een product is van een democratisch politiek systeem, eindigen we het hoofdstuk met een korte beschouwing over de mate van pluriformiteit op verschillende gebieden. In de conclusie komen we vervolgens terug op de plaats van Turkije in het schema van de 'Botsing der Beschavingen' en de implicaties die deze heeft voor de toetreding van Turkije tot de EU. 
DE EUROPESE UNIE, TURKIJE EN DE ISLAM 


\section{HET HEDENDAAGSE ISLAMITISCHE LANDSCHAP VAN TURKIJE}

Dit hoofdstuk beschrijft de belangrijkste aspecten van de hedendaagse Turkse islam. Omdat de huidige situatie het resultaat is van een aantal ingrijpende transformaties in het verleden, wordt telkens, uitgaande van de belangrijkste actuele ontwikkelingen, teruggegrepen naar de historische achtergronden die deze beslissend hebben beïnvloed.

\subsection{ISLAM EN STAAT}

\subsubsection{HET '28 FEBRUARI-PROCES': CONFRONTATIE TUSSEN RELIGIE,} MAATSCHAPPIJ EN STAAT

Op 28 juni 1996 gebeurde er in Turkije iets wat in de geschiedenis van de in 1923 opgerichte republiek tot dan toe ondenkbaar was geweest: een politicus die zich politiek en persoonlijk uitdrukkelijk liet inspireren door islamitische normen en waarden werd ingezworen als premier. Necmettin Erbakan, de leider van de Welvaartspartij, had deze positie te danken aan zijn verkiezingsoverwinning van december 1995 (toen hij 21,3 procent van de stemmen haalde) en aan de gewiekste manier waarop hij gebruik had weten te maken van de verdeeldheid onder de andere politieke partijen. Erbakans regeringscoalitie met de conservatieve, westers georiënteerde en seculiere Partij van het Juiste Pad leek een nieuwe periode in de moderne Turkse geschiedenis in te luiden, maar al snel werd duidelijk dat deze ontwikkeling door het seculiere staatsapparaat niet werd getolereerd.

Op 28 februari 1997 lanceerde de Turkse legerleiding een campagne, waarin zij 'islamitisch fundamentalisme' (irtica, letterlijk: reactionaire gezindheid) identificeerde als de grootste bedreiging voor de veiligheid van Turkije, erger dan Koerdisch separatisme of bedreigingen van buiten de landsgrenzen. Via de Nationale Veiligheidsraad, het zeer machtige orgaan waarbinnen de legerleiding het kabinet van advies dient, presenteerde het leger een lijst van achttien eisen waaraan de regering-Erbakan te voldoen had. De impliciete dreiging achter het eisenpakket was duidelijk: het leger zou de regering ten val brengen als de eisen niet werden ingewilligd. Toen de regering-Erbakan aarzelde en treuzelde bij de uitvoering van de eisen, organiseerde het leger een campagne, waarbij de media, de rechterlijke macht, de bureaucratie en uiteindelijk ook de volksvertegenwoordigers van de Partij van het Juiste Pad werden bewerkt en gemobiliseerd tegen de regering. Werknemers- en werkgeversorganisaties vormden in eigen kring het 'Secularisme Front'. Als resultaat van de uitgeoefende druk viel de regering-Erbakan op 18 juni 1997.

Dit ' 28 februari-proces', dat in Turkije wordt aangeduid als een 'zachte staatsgreep' of ook wel als een 'postmoderne staatsgreep', ging ook na de val van het kabinet door. De maatregelen die de militairen doorgevoerd wilden zien, waren 
ingrijpend en besloegen een wijd terrein. Een van hun belangrijkste eisen was de invoering van achtjarig basisonderwijs. Het basisonderwijs telde tot dan toe in Turkije vijf jaar en veel ouders stuurden hun kinderen daarna, ofwel uit overtuiging ofwel uit financiële noodzaak, voor drie jaar naar de islamitische scholen voor religieuze vorming, de imam-hatip okulları (scholen voor zielzorgers en predikers). Door nu het verplichte staatsonderwijs op acht jaar te stellen, werd deze islamitische scholen hun markt ontnomen. Deze en vele andere door het leger afgedwongen maatregelen werden door Erbakans opvolgers in 1997-1999 genomen. In januari 1998 beval het Constitutioneel Hof bovendien de opheffing van de Welvaartspartij en de verbanning van Erbakan uit de politiek voor een periode van vijf jaar, een vonnis dat overigens door het Europese Hof voor de Mensenrechten werd bevestigd (Yavuz 2003: 3, 244).

Het besluit van het Constitutioneel Hof was gebaseerd op de artikelen 68 en 69 van de Turkse grondwet, die na een eerdere staatsgreep in september 1980 door de toenmalige militaire junta was ingevoerd. Deze artikelen bepaalden dat er geen politieke partijen kunnen worden opgericht die "in strijd zijn met de principes van de seculiere republiek" (art. 68) en dat partijen die "religieuze gevoelens, symbolen of argumenten gebruiken", verboden zullen worden (art. 69). Interessant was ook de motivatie van het hof. Het benadrukte daarin dat religie geen rol diende te spelen in het politieke en sociale leven en dat "religie het innerlijke aspect van het individu stuurt, terwijl secularisme het uiterlijke aspect van het individu stuurt". Hiermee plaatste het hof zich vierkant in de traditie van het kemalisme, de staatsideologie van Turkije zoals die vanaf de jaren twintig vorm had gekregen (Yavuz 2003: 247).

Om de positie en de argumenten van de spelers in deze confrontatie over de verhouding tussen religie, maatschappij en staat goed te begrijpen, is inzicht nodig in twee factoren die de huidige situatie historisch hebben bepaald. Ten eerste is dat het denken over staat en religie in het Osmaanse rijk (1300-1922), de directe voorloper van de Republiek Turkije. Ten tweede is dat het seculariseringsproces, dat in het Osmaanse rijk vanaf ongeveer 1840 in gang is gezet en in de Republiek Turkije tussen 1923 en 1945 zijn hoogtepunt bereikte.

\subsubsection{ISLAM EN STAAT BIJ DE OSMANEN}

De Osmaans-islamitische erfenis van de Republiek Turkije is op haar beurt weer een traditie die put uit twee, heel verschillende en deels zelfs tegenstrijdige bronnen: ten eerste de islamitische wortels van de maatschappij en ten tweede de Turkse traditie van staatsvorming en staatsinrichting zoals die vanaf de zesde eeuw in Centraal-Azië, en vanaf de tiende eeuw in het Midden-Oosten vorm heeft gekregen.

De oudste islamitische gemeente, die zich na 622 in Yathrib, het latere Medina, rond de profeet Mohammed vormde, was een zichzelf besturende gemeenschap. De leiders van de gemeenschap ontleenden hun legitimiteit aan religieus 
charisma en bestuurden de moslims in oorlog en in vrede. Logischerwijs voorzagen de regels die de fundamenten vormden van de vroege islamitische gemeenschap niet in het bestaan van een staat boven of buiten de gemeenschap van de gelovigen. Het leven van de gelovigen werd geregeld door een systeem van religieuze normen en regels, dat werd gehoed door de religieuze leiders. In de begintijd waren dat Mohammed en zijn directe volgelingen en opvolgers (de 'rechtgeleide kaliefen'), maar al snel werd dit bij uitstek het werkterrein van religieuze specialisten, de godsdienstgeleerden (oelema). De oelema werkten de uitspraken in de koran en de overleveringen over wat de profeet Mohammed had gedaan en gezegd uit tot een rechtssysteem (de shari'a, of in het Turks şeriat), dat de basis vormde voor het maatschappelijke en persoonlijke leven. In de ogen van de moslims was en is de şeriat Gods werk. De regels kunnen wel geïnterpreteerd worden, maar in principe is het systeem onveranderlijk en is wetgeving door mensen een onmogelijkheid.

In de negende eeuw, tweehonderd jaar na het optreden van Mohammed, kreeg de islam een meer orthodox karakter doordat de vrije interpretatie van de şeriat door individuele rechtsgeleerden niet meer legitiem werd geacht. Vanaf toen diende interpretatie beperkt te blijven tot discussie over het werk van de vroege exegeten, van wie het werk daarmee een enorme autoriteit verkreeg (Yerasimos et al. 2000: 13-15; Mardin 1989: 20-21).

Met de razendsnelle verovering van gebieden, van Spanje in het westen tot India in het oosten, werd de vestiging van een solide bestuurssysteem, van een staat, onontkoombaar. Het denken van de islamitische rechtsgeleerden over de staat had vanaf het begin iets tweeslachtigs. Aan de ene kant was de staat een noodzakelijk instituut, zonder welk de handhaving van de religieuze orde en de vervulling van Gods plan met de mensheid niet mogelijk was. In een boze wereld kon het ware geloof zonder de bescherming van de staat niet overleven. Aan de andere kant was de opvatting wijdverbreid dat macht corrumpeert en staatsbestuur en vroom en goed leven niet samen konden gaan (Lewis 1996: 157-8). Dat dit laatste als onvermijdelijk werd gezien, laat zich illustreren aan de hand van een Osmaans voorbeeld: geen van de Osmaanse sultans tussen 1300 en 1922 volbracht ooit de hadj, de pelgrimstocht naar Mekka, die in principe voor iedere moslim een plicht is. De consensus van de godsdienstgeleerden was dat de staatkundige plicht van de sultan: het beschermen van het 'huis van de islam' (dar ulislam), boven zijn persoonlijke zielenheil ging.

In de ogen van de oelema was de islamitische staat in zijn ideaalvorm een theocratie, met God als enige bron van legitimiteit en recht. Tegelijkertijd beseften de moslims in de praktijk dat hun wereldlijke heerser, 'Gods schaduw op aarde', om het staatsbestel draaiende te houden, regels moest maken en straffen moest opleggen, die een aanvulling waren op wat er in de religieuze wet verankerd lag. De bevoegdheid van vorsten om dit te doen, werd in het Arabisch aangeduid als siyâsa (in het moderne Turks voortlevend als 'politiek': siyaset) of equivalenten daarvan, zoals urf(Turks: örf). Voor het afkondigen van dit soort voorschriften 
en regels hadden vorsten wel de dekking nodig van de vooraanstaande godsdienstgeleerden. Die moesten immers verklaren dat de regelgeving weliswaar aanvullend was op de şeriat, maar niet daarmee in strijd (Lewis 1996: 223-4).

Vanaf de tiende eeuw kwam nagenoeg het hele kerngebied van de islam onder het bestuur van Turkse dynastieën die hun oorsprong in Centraal-Azië hadden. Deze dynastieën waren vrijwel zonder uitzondering al voordat zij het MiddenOosten binnendrongen op de Centraal-Aziatische steppen tot de islam bekeerd. Daarnaast brachten zij ook de sterke militaire en politieke tradities met zich mee die de Turken hadden ontwikkeld. Deze vermengden zich in de grensgebieden tussen het Midden-Oosten en Centraal-Azië met de oude Perzische koningstraditie, die een zwaar accent legde op de onafhankelijke autoriteit van de vorst.

Het soort islam dat de Turkse dynastieën omarmden, was, ook al naar het voorbeeld van de Perzische rijken die zij op hun weg tegenkwamen, de soennitische richting en daarbinnen weer de hanafitische rechtsschool. Dat laatste gegeven is relevant voor de manier waarop de Turkse dynastieën de relatie tussen staat en islam hebben vormgegeven, want van de vier rechtsscholen die binnen de soennitische islam bestaan, is het de hanafitische school die de meeste gelegenheid voor 'Realpolitik' biedt. De hanafitische theorie over het heerserschap definieert eenvoudigweg diegene als legitieme heerser die erin slaagt de macht te grijpen en te houden (Imber 1997: 24, 67). Voor de Turkse nieuwkomers uit de steppe, van wie de macht op het zwaard berustte, was dit natuurlijk een aantrekkelijke propositie, al ontwikkelden zij naarmate hun macht toenam ook andere argumenten die de legitimiteit van hun gezag moesten schragen, zoals gefingeerde genealogieën of, zoals bij de Osmanen, de mythe rond de 'overdracht' van het kalifaat door de laatste Arabische Abbasiedenkalief aan de Osmaanse sultan.

Meer dan enige andere dynastie zijn de Osmanen erin geslaagd de islamitische en de Turks-Perzische tradities in één bestuurlijk systeem met elkaar te verenigen. Officieel was het Osmaanse rijk een islamitische staat, waarin het de taak van de heerser, de sultan, was om het land van de moslims te beschermen en ervoor te zorgen dat zij daarbinnen als goede moslims konden leven. Formeel was de basis van het rechtssysteem de şeriat, de goddelijke wet. In de praktijk beperkte de werkingskracht van de şeriat zich grotendeels tot wat wij de privaatrechtelijke sfeer zouden noemen: familierecht en het recht van overeenkomsten. Alles wat in hedendaagse termen als publiekrechtelijk zou worden aangemerkt, en vooral alles wat met de openbare orde en het openbaar bestuur te maken had, werd gereguleerd in verzamelingen van edicten (kanun, van het Byzantijnse canon) die uit naam van de sultan waren uitgegeven. De gebieden waarbinnen de beide rechtssystemen geldigheid hadden, waren natuurlijk verschillend. De şeriat was de wet van de moslimgemeenschap, zowel binnen als buiten het rijk. Ook moslims in Zuidoost-Azië of China regelden hun persoonlijke leven volgens de voorschriften van deze wet. Aan de andere kant was de şeriat weer niet van toepassing op de christelijke en joodse gemeenschappen binnen het rijk, die in belangrijke mate autonoom waren. De kanun daarentegen was de wet van een 
staat en gold dus binnen de grenzen van die staat, maar daarbinnen ook voor alle onderdanen.

Het was de taak van de leidende oelema, en met name van de hoogste moefti (juridisch adviseur) van het rijk, de şeyhülislam, om de heilige wet en sultansedicten met elkaar in overeenstemming te brengen (Poulton 1997: 34-5). Hierbij hielden de religieuze autoriteiten en het paleis elkaar in een wederkerige omklemming. Aangezien de sultan pretendeerde een islamitisch vorst, ja zelfs de islamitische vorst bij uitstek, te zijn, kon hij de legitimering van de kenners van de islamitische wet niet ontberen. Daar stond tegenover dat, veel meer nog dan hun voorgangers, de Osmaanse sultans erin slaagden de oelema via een streng gereguleerd systeem van benoemingen en controle deel te maken van het staatsapparaat. Dit gaf het hof natuurlijk een groot arsenaal aan drukmiddelen op onwillige oelema.

In weerwil van het theocratische ideaal van de islamitische rechtsgeleerden was de Osmaanse staat dus in de praktijk een seculier bestuursapparaat waarvan het beleid religieus werd gelegitimeerd. De islam speelde daarbij als 'grote traditie' met een hegemoniaal karakter de hoofdrol als culturele en politieke brug tussen de staatselite en de massa van het grootste en dominante segment van de bevolking: de soennitische moslims (Yavuz 2003: 38-9). Zonder de sacralisatie van het Osmaanse bestuur zoals die op deze manier plaatsvond, had het Osmaanse rijk hoogstwaarschijnlijk de loyaliteit van zijn islamitische bevolking niet kunnen behouden en niet zeshonderd jaar kunnen overleven.

\section{1 .3}

SECULARISERING IN HET OSMAANSE RIJK

Uit het voorafgaande moge duidelijk zijn dat het vaak gehoorde cliché dat de islam geen scheiding tussen 'kerk en staat' kent een enorme vertekening van de werkelijkheid is. Omdat de islam als autonome gemeenschap is ontstaan, is binnen de islam, althans bij de godsdienstgeleerden, de theorievorming over de staat buiten de geloofsgemeenschap zwak ontwikkeld. Daar staat tegenover dat de Turkse islamitische staten, en met name het Osmaanse rijk, een uitgebreide en gecodificeerde praktijk hebben ontwikkeld van de facto seculier bestuur. Politieke legitimiteit was in essentie tweehoofdig: islam en staat (of: vorst) waren beide bronnen van regelgeving (Mardin 1989: 21). Het was deze tweehoofdigheid, dit bestaan van een praktijk van regelgeving en instituties die weliswaar religieus gesanctioneerd waren, maar in essentie voortkwamen uit de autonome beslissingsbevoegdheid van de vorst, die het mogelijk maakte dat in de negentiende eeuw een moderniseringsproces op gang kwam dat secularisatie met zich meebracht.

In het laatste deel van de achttiende en in het begin van de negentiende eeuw leed het Osmaanse rijk een aantal traumatische nederlagen tegen Europese staten. In 1774, 1792 en 1829 werden oorlogen tegen Rusland verloren. Dit had om twee redenen catastrofale gevolgen voor het gezag van de Osmaanse sultan. 
In de eerste plaats verloren de Osmanen de controle over de Zwarte Zee, waarvan zij voor de voedselvoorziening van hun hoofdstad Istanbul afhankelijk waren, en in de tweede plaats moest de sultan gebied dat bewoond werd door moslimbevolkingen afstaan aan niet-islamitische heersers (de Russische tsaar). In dezelfde periode vond de bezetting van de toenmalige Osmaanse provincie Egypte door Napoleon Bonaparte plaats (1798-1801), waarmee Europese machthebbers voor het eerst sinds de kruistochten een van de hartlanden van het islamitische Midden-Oosten, met Caïro als tweede stad van het rijk, in handen kregen.

De schok van deze nederlagen bracht een kring van hervormingsgezinde bestuurders in Istanbul ertoe te bepleiten dat de Osmaanse staatsinstellingen naar Europees voorbeeld gemoderniseerd zouden worden. Het grote voorbeeld daarbij was Frankrijk, zowel het Frankrijk van de Bourbons als dat van de Franse Revolutie en van Napoleon. Na in 1808 uit de macht verdreven te zijn, wisten de hervormers onder de autocratische sultan Mahmut II (r. 1808-1839) vanaf 1826 hun politiek door te zetten. Hun hervormingen waren in eerste instantie gericht op versterking van de macht van de centrale staat, zowel naar binnen als naar buiten. De eerste zorg daarbij was de modernisering van het leger, maar met de vorming van een leger naar Europees model als vertrekpunt verspreidden de hervormingen zich als een inktvlek. Er waren fabrieken nodig voor uniformen, opleidingsinstituten voor officieren, bevolkingsregisters om dienstplicht mogelijk te maken en efficiëntere belastinginning om alles te kunnen betalen.

In de loop van de negentiende eeuw kreeg het Osmaanse rijk langzamerhand het uiterlijk van een typische moderne staat. Er kwamen staatsscholen in iedere stad, posterijen, spoorwegen, klokkentorens (met een geüniformeerde tijd voor het hele rijk) en vuurtorens, musea, bevolkingstellingen, geboortebewijzen en paspoorten. Het kleine staatsapparaat van het begin van de negentiende eeuw groeide zestigvoudig en kreeg de typische karakteristieken van een bureaucratie.

Het edict uit 1839, waarmee de sultan zijn voornemen aankondigde verregaande hervormingen door te voeren (het 'Hatti Şerif van Gülhane' of 'Nobele Edict van het Rozenpaviljoen'), bewees uitdrukkelijk lippendienst aan de religieuze wet. In de preambule werd met zoveel woorden gezegd dat 'landen die niet door de şeriat werden geregeerd, niet konden voortbestaan'. (Deringil 1998: 9). De maatregelen zelf hadden echter met de religieuze wet weinig of niets van doen. Integendeel, ze hadden duidelijke seculariserende neveneffecten. In eerste instantie waren deze effecten eerder impliciet. De pupillen op de nieuwe scholen voor artsen en veeartsen, de ingenieurs en artilleristen die met moderne wiskunde te maken kregen, werden de dragers van een materialistisch, natuurwetenschappelijk wereldbeeld.

In de loop van de jaren vijftig en zestig van de negentiende eeuw kreeg de secularisatie ook een juridisch en institutioneel gezicht door de invoering van nieuwe, aan Europa ontleende wetboeken, zoals het wetboek voor strafrecht of het 
handelswetboek en de inrichting van nieuwe rechtbanken, raden en ministeries naar Europees voorbeeld. De şeriat werd nooit buiten werking gesteld, maar het terrein waar de heilige wet zijn autoriteit kon laten gelden, schrompelde steeds verder ineen. De nieuwe wetten en procedures waren immers grotendeels gemodelleerd naar Franse voorbeelden en weerspiegelden dus ook de praktijk in dit bolwerk van de laïcité (Dumont in Landau (ed.) 1984: 35-37).

Net als in andere Europese monarchieën kwam ook in het Osmaanse rijk na 1848 het zuiver traditionele concept van een door God gegeven koningschap, alleen gelegitimeerd door godsdienst en traditie, meer en meer ter discussie te staan. Onder druk van een opkomend nationalisme onder de niet-islamitische bevolkingsgroepen en, vanaf 186o, ook van een embryonale liberale beweging, begon de zoektocht naar een nieuw soort legitimiteit met een nationale en democratische dimensie (Hobsbawm 1990: 84). De machtselite van het Osmaanse rijk kwam tot de conclusie dat het niet langer voldoende was dat de staat beschikte over gehoorzame onderdanen. In de concurrentie met de staten van Europa was het nodig dat er een appèl aan de massa van de bevolking gedaan zou kunnen worden om de nationale krachten te mobiliseren. Van de onderdanen binnen het rijk moesten Osmaanse burgers gemaakt worden die zich identificeerden met 'hun' staat. Dit was alleen mogelijk, indien het al mogelijk was, door de bevolking zeggenschap te geven in het bestuur van de staat via een proces van impliciete onderhandelingen tussen staat en onderdanen (Deringil 1998: 45). Omdat het Osmaanse rijk tot 1878 een staat was waarin niet-moslims ongeveer veertig procent van de bevolking uitmaakte, was dit dus impliciet een secularisatieproces.

Gedurende ongeveer twintig jaar, van 1856 tot 1876 was dit 'osmanisme' (Turkse term: ittihadi anasir, eenheid der elementen) het ideologische richtsnoer voor de politiek. Het culmineerde uiteindelijk in de afkondiging van de Osmaanse grondwet en de verkiezingen voor het eerste Osmaanse parlement, beide in 1876 . De grondwet vermeldde geen staatsreligie en in het parlement waren de nietmoslims proportioneel vertegenwoordigd. Tegelijk werden grondwet en parlement wel bepleit met argumenten die naar de islam verwezen, net zoals dat een kleine veertig jaar eerder met het eerste grote hervormingsdecreet ook het geval was geweest. Deze argumentatie vond plaats in een vertoog dat in de jaren zestig van de negentiende eeuw door een groep jonge bureaucraten, de zogenaamde 'Jong Osmanen' was vormgegeven. Zij verdedigden liberale waarden met islamitische argumenten en probeerden door herinterpretatie van koranteksten en islamitische tradities aan te geven dat democratie eigenlijk inherent was aan de islam (Zürcher en Van der Linden 1995: 80; Mardin 1979: 381-443).

De verloren oorlog tegen Rusland van 1877-1878 was in dit opzicht een breekpunt. De oorlog was dramatisch verlopen en geëindigd met Russische troepen in de voorsteden van Istanbul. Door het gebiedsverlies dat het Osmaanse rijk met het Verdrag van Berlijn opliep en de daarmee gepaard gaande migratie van grote groepen moslims uit de Balkan en de Kaukasus veranderde de bevolkingssamen- 
stelling van het rijk radicaal. $\mathrm{Na} 1878$ was meer dan tachtig procent van de bevolking moslim. Osmaans burgerschap, concreet uitgedrukt in grondwet en parlement, had het land niet voor rampen kunnen behoeden en was als ideologisch uitgangspunt in diskrediet gebracht. De staat stond dus voor de taak een ander ideologisch bindmiddel te vinden dat de nieuwkomers en de autochtone bevolking van het zwaar aangeslagen rijk kon verenigen (Yavuz 2003: 43-44).

Gedurende de lange regering van sultan Abdülhamit II (r. 1876-1909) werden de bakens verzet. Deze Osmaanse sultan, die nu ook zijn religieuze functie van kalief sterk ging benadrukken, lanceerde een ideologisch offensief dat erop was gericht een nieuwe basis voor solidariteit onder de moslimonderdanen van het rijk te scheppen. Net als de Habsburgs in Oostenrijk-Hongarije en de Romanovs in Rusland reageerden de Osmanen op de bedreigingen van nationalisme en liberalisme door een eigen 'officieel nationalisme' te lanceren dat sterk religieus gekleurd was en beoogde de monarchie een nieuwe mystiek en zeggingskracht te geven (Deringil 1998: 47, 67; Anderson 1991: 83-111).

De ambitie van het Osmaanse hof om de islam in te zetten als een sociaal cement en als een middel ter versterking van de staatsmacht leidde ertoe dat de staat zich op een tot dan toe ongehoorde manier ging bemoeien met de inhoud en de verspreiding van het geloof. De islam moest staatsgetrouw, uniform en controleerbaar worden op een schaal zoals hij dat nooit was geweest. Er kwamen dus reglementen voor koranuitgaven, voor religieus onderwijs op scholen en voor de preken in de moskee. Het belangrijkste product van deze standaardisering van de islam door de staat was de codificatie, naar het model van een Europees wetboek, van de religieuze wet: de Mecelle, waaraan een staatscommissie jarenlang werkte. Deze standaardtekst werd vervolgens tot in alle uithoeken van het rijk verspreid (Deringil 1998: 50).

De islampolitiek van sultan Abdülhamit was in deze zin dus absoluut geen terugkeer naar oudere Osmaanse tradities. Integendeel, de ideologische 'drive' ging hand in hand met een enorme uitbreiding van het moderne onderwijs, de communicatiemiddelen (telegraaflijnen, spoorwegen) en de drukpers. De moderne staat, met zijn ambitie om het leven van de burgers tot in de details te reguleren, heeft in deze periode zijn oorsprong en de Republiek Turkije zou zonder de erfenis van Abdülhamit ondenkbaar zijn geweest.

De constitutionele revolutie van juli 1908, die direct leidde tot het herstel van de in 1878 opgeschorte grondwet en het parlement en indirect (in april 1909) tot de val van sultan Abdülhamit, was het werk van de zogenaamde 'Jong Turken', jonge officieren en ambtenaren die opgeleid waren aan de moderne, naar Europees voorbeeld ingerichte onderwijsinstellingen die onder Abdülhamit waren ontwikkeld. Deze Jong Turken zagen het oude regime als corrupt en machteloos, met name tegenover Europa, en vonden de tijd rijp voor een nationaal reveil. Een constitutioneel parlementair regime was in hun ogen een van de technische middelen om tot dit reveil te komen, maar geen doel op zich (Hanioğlu 1995: 214-16). 
Het Jong Turkse regime, dat van 1908 tot 1918 zou duren, was in sommige opzichten een voortzetting van dat van Abdülhamit. Ook de Jong Turken streefden naar vergroting van de macht van de staat (waarvan zij vrijwel zonder uitzondering ook dienaren waren), naar centralisatie en standaardisatie. Dit bracht hen al snel in conflict met de niet-islamitische bevolkingsgroepen van het rijk, die van de constitutionele revolutie juist decentralisatie en zelfs autonomie hadden verwacht. Zeker vanaf het uitbreken van de Balkanoorlog (1912), waarin het Osmaanse rijk werd aangevallen door vier christelijke Balkanstaten, werd de tegenstelling 'moslim- niet-moslim' de breuklijn die dwars door de maatschappij heen liep (zie ook par. 2.5). De Jong Turken mobiliseerden de bevolking op basis van een nationalistische ideologie, waarin het samenbindend element, net als in de tijd van Abdülhamit, de islam, althans het behoren tot de islamitische bevolkingsgroep, was (Zürcher: Karpat (ed.) 2000: 150-179).

Paradoxaal genoeg waren de Jong Turken, die een op religieuze 'markers' gebaseerd nationalisme propageerden, zelf allesbehalve vrome of traditionele moslims. Zij stonden sterk onder de invloed van materialisme en positivisme. De rol van de islam zagen zij vooral als een sociaal cement, maar tegelijk werden ze bezield door een sterk antiklericalisme. De islam moest gezuiverd worden van het bijgeloof van de mystiek en van het benepen conservatisme van de oelema. Dergelijke opvattingen zouden niet langer de kans krijgen invloed uit te oefenen op het bestuur of om de vrijheid van denken te hinderen (Zürcher, 'Ottoman sources of Kemalist thought'). De 'ware' islam die dan zou ontstaan, zou progressief zijn en openstaan voor wetenschap en technologie. Volgens sommige van de meer extreme Jong Turkse schrijvers was de islam niet alleen de rationele godsdienst bij uitstek, maar eigenlijk zelfs identiek aan het positivisme. Islam moest in overeenstemming met wetenschap gebracht worden, of zoals Abdullah Cevdet, een van de meest secularistische Jong Turkse denkers, het formuleerde: "Religie is de wetenschap van de massa's en wetenschap is de religie van de elite”(Hanioğlu 1997: 133-158).

Verschillende opvattingen van de Jong Turken leidden inderdaad tot concrete maatregelen die de bevoegdheden van de godsdienstgeleerden en de heilige wet verder beperkten en de greep van de staat op de islam vergrootten. In 1916 verloor de hoogste moefti, de şeyhülislam, zijn zetel in het kabinet en werd zijn ministerie gedegradeerd tot een afdeling. Hij verloor zijn jurisdictie over de religieuze rechtbanken aan het ministerie van Justitie, terwijl het beheer van de stichtingen met een aan God welgevallig doel, de evkaf, werd overgeheveld naar het ministerie van Financiën. Dit laatste was zeer ingrijpend, omdat alle religieuze en charitatieve instellingen in het rijk, zoals moskeeën, medreses (religieuze hogescholen), ziekenhuizen en bibliotheken, voor hun inkomen afhankelijk waren van deze, door weldoeners uit het verleden opgerichte stichtingen. De islamitische instellingen verloren dus hun financiële onafhankelijkheid. Religieuze scholen werden nu onder het toezicht van het ministerie van Onderwijs geplaatst. In 1917 liet de regering ook het familierecht opnieuw codificeren. Hierbij bleven weliswaar de gebruiken van de verschillende geloofsgemeenschappen 
intact (bij de moslims dus de voorschriften van de şeriat), maar alleen al het feit dat de staatsgerechtshoven nu het toezicht hielden op de naleving van de regels, was een stap in de richting van secularisme. Het aannemen van de Europese (gregoriaanse) kalender voor overheidsgebruik in 1917 maakte de scheiding van staat en islam nog meer zichtbaar (Dumont in Landau (ed.) 1984: 37-38).

Zowel wat betreft de onderliggende wereldvisie als wat betreft de concrete maatregelen waren de Jong Turken in deze periode de wegbereiders van de 'kemalistische revolutie' zoals die vanaf de jaren twintig in de Republiek Turkije gestalte zou krijgen.

\subsubsection{HET KEMALISTISCHE IDEAAL}

Voor Turkije duurde de Eerste Wereldoorlog niet, zoals in de rest van Europa, tot 1918, maar, enigszins vergelijkbaar met de situatie in Rusland, tot 1922. Via een bittere onafhankelijkheidsoorlog, die niet direct werd gevoerd tegen de overwinnaars uit de Eerste Wereldoorlog, Engeland en Frankrijk, maar tegen hun lokale bondgenoten, de Armeniërs in het oosten en de Grieken in het westen, werd de opdeling van wat er nog over was van het Osmaanse Rijk ongedaan gemaakt. De overwinning kreeg uiteindelijk gestalte in het Vredesverdrag van Lausanne (1923), waarmee het tegenwoordige Turkije op de kaart kwam als onafhankelijke nationale staat. Met de overwinning verdween de noodzaak de bevolking te mobiliseren met behulp van religieuze motieven. Alle aandacht kon vanaf 1923 dus gewijd worden aan de ontwikkeling van het land.

Mustafa Kemal Pasja (na 1934: Atatürk), de leider van de onafhankelijkheidsstrijd en na oktober 1923 de eerste president van de nieuwe Republiek Turkije, behoorde met zijn kring tot de radicale vleugel van de Jong Turken. Zij waren er ten diepste van overtuigd dat alleen rationalisme en wetenschap de basis konden vormen voor de versnelde modernisering van Turkije. Het vertoog over de islam van deze kemalisten paste naadloos bij dat van de Jong Turken uit de periode voor 1918. Mustafa Kemal benadrukte telkens weer dat hij niet tegen de islam was, omdat de 'ware' islam een rationele en natuurlijke religie was. Tegelijk gebruikte hij iedere geschikte gelegenheid om de oelema en in het bijzonder de niet aan de staat gelieerde religieuze voormannen, zoals soefisjeiks, wonderdoeners en heiligen, aan te vallen. Islam, zoals door hem gepropageerd, was een individuele geloofsovertuiging die geen middelaars nodig had tussen mens en God.

In de praktijk leidden deze opvattingen tot een confrontatie met de islam in Turkije langs verschillende lijnen. In de eerste plaats werd het proces voltooid waarbij de instituties van de religie geheel onder controle van de na 1928 officieel seculiere staat werden gebracht. Het kalifaat werd in 1924 afgeschaft, evenals het aparte religieuze onderwijs. De grondwet van 1924 vermeldde weliswaar de islam als staatsgodsdienst, maar deze passage werd in 1928 geschrapt. De functie van şeyhülislam werd afgeschaft, maar vervangen door een nieuw orgaan, het Presidium voor Religieuze Zaken (Diyanet Işsleri Başkanlığı, Diyanet), dat direct 
onder de premier kwam te ressorteren. Dit orgaan kreeg zeggenschap over alle religieuze aspecten van het leven van de Turken. Het controleerde en bestuurde alle moskeeën, heiligengraven en derwisjkloosters (tot aan hun sluiting in 1925), het benoemde zowel alle predikers (imams) en andere aan de moskee verbonden functionarissen als alle moefti's (adviseurs in geloofskwesties). Het verschafte vanuit het centrum in Ankara instructie, zowel over de inhoud van de preken als over die van de religieuze adviezen. Paradoxaal genoeg eigende de seculiere Republiek Turkije zich hiermee meer religieuze authoriteit toe dan de sultankalief ooit had gehad (Dumont in Landau (ed.) 1984: 38).

Deze maatregelen vormden eigenlijk het sluitstuk van een eeuw secularisatie van instellingen en ze waren met name een logische voortzetting van de maatregelen van de Jong Turken uit 1916-1917. De positie van de oelema werd nog verder uitgehold doordat de heilige wet in 1926 werd afgeschaft op het laatste gebied waar die nog geldigheid had: het familierecht. De vervanging van de negentiende-eeuwse codificatie van de şeriat, de Mecelle, door een adaptatie van het Zwitserse burgerlijk wetboek was een radicale stap die tot op de dag van vandaag uniek is gebleven in de islamitische wereld.

Waar de aan de staat gelieerde islam onder strikte controle werd gebracht, werden de autonome islamitische bewegingen, met name de mystieke broederschappen (tarikats), in 1925 eenvoudigweg verboden. De derwisjkloosters (tekkes), die de centra van de broederschappen vormden, werden gesloten, net zoals de heiligengraven (türbes), die vaak populaire bedevaartsoorden waren. Het probleem van de tarikats, hun rol in de maatschappij en hun erfenis is dermate belangrijk dat het in paragraaf 2.2 apart wordt behandeld.

Maatregelen als de invoering van het Zwitsers familierecht of het verbod op de derwisjordes raakten de mensen, hoog en laag, in hun directe persoonlijke levenssfeer en veroorzaakten dan ook aanzienlijk meer ongenoegen en protest dan de afschaffing van instituties als het kalifaat of de functie van şeyhülislam had gedaan. Hetzelfde gold voor een ander soort maatregelen, die misschien het best kan worden omschreven als een aanval op de islamitische cultuur. De jaren twintig en dertig waren een periode waarin ook het uiterlijk van Turkije sterk veranderde door regelgeving die de publieke ruimte en tijd opnieuw inrichtte. Kledingvoorschriften die traditionele hoofdtooi verboden, invoering van de Europese klok en tijdrekening, de vervanging van het Arabische schrift door het Latijnse, de aanleg van parken en terrasjes, het oprichten van standbeelden van Atatürk, het waren allemaal maatregelen die niet direct betrekking hadden op het geloof, maar die heel duidelijk een heroriëntatie inhielden: weg van de cultuur van het Midden-Oosten en in de richting van Europa. De massa van de bevolking begreep de boodschap in veel gevallen echter wel degelijk als een aanval op het geloof. Hoofdtooi was in het Midden-Oosten al eeuwen een onderscheidend kenmerk waaraan iemands sociale en religieuze positie was af te lezen en het Arabische schrift werd, juist door dorpelingen die eigenlijk alleen in de moskee contact met schriftcultuur hadden, meteen geassocieerd met de taal 
van de koran. Het culturele offensief had daardoor sterk anti-islamitische connotaties (Zürcher 1995: 229-232).

De gedaanteverwisseling die in ieder geval het stedelijke Turkije onderging, maakte ook in het buitenland grote indruk. Talloze bezoekers legden in boeken over het 'nieuwe' Turkije getuigenis af van hun bewondering. Dit verklaart ook de titels van sommige van de boeken, zoals De sluiers vallen! Of Allah onttroond. De schrijvers hadden doorgaans geen notie van de honderd jaar voorgeschiedenis van de secularisering in Turkije en schreven de veranderingen alleen aan de republiek van Atatürk toe.

Gedurende de eerste twintig jaar van haar bestaan kon de republiek voor religieuze kennis putten uit het arsenaal aan, op de hogere niveaus vaak zeer goed opgeleide Osmaanse oelema. In tegenstelling tot hun Jong Turkse voorgangers, die hadden geprobeerd het lesprogramma van de religieuze opleidingen te moderniseren, zagen de kemalisten echter heel weinig in de hervorming van de opleidingen voor oelema. De twee dozijn opleidingen voor predikers en voorgangers die het land rijk was, werd in 1930-1931 gesloten en de theologische faculteit van de Universiteit van Istanbul, toen nog de enige universiteit van Turkije, onderging in 1935 eenzelfde lot. Dit creëerde op de langere termijn een ontbrekende generatie, een 'missing link' in de Turkse islam en een breuk met de grote Osmaanse traditie van religieuze wetenschap.

Dat de kemalisten zo ver gingen in hun beleid om de islam terug te dringen uit het openbare leven had alles te maken met hun besef dat zij in hun opvattingen een minderheid vormden. Zij zagen zichzelf als de leraren van een achtergebleven natie, met een missie het volk aan de haren de moderne tijd in te slepen volgens het kemalistische adagium 'ondanks het volk voor het volk' (halka rağmen halk için). Ze kenden de mobiliserende kracht van islamitische slogans en waren voortdurend op hun hoede voor 'religieuze reactie' (irtica). Deze term, die tot op de dag van vandaag voortdurend door secularisten in Turkije wordt gebruikt, was in zwang geraakt tijdens de islamitisch geïnspireerde contrarevolutie van april 1909. Deze opstand was voor de hele generatie Jong Turken, waartoe ook Atatürk en de zijnen behoorden, een traumatische ervaring geweest. Minder dan een jaar na de constitutionele revolutie waren de 'bevrijders' door een islamitische slogans hanterende meute uit de hoofdstad verjaagd. Weliswaar slaagden troepen onder Jong Turkse leiding erin om binnen twee weken een einde aan de opstand te maken, maar toch: het dodelijke gevaar van een politiek uitgebuite islam had zich in de hoofden van de Jong Turken gegrift en ook in de republiek bleven zij tekenen van oppositie in dit licht interpreteren. Dit gold voor de Koerdische opstand van 1925, de moord op een reserveofficier door een groepje derwisjen in Menemen bij Izmir in 1930, het optreden van Sait Nursî en vele kleinere incidenten (zie ook par. 2.2.6). De angst voor de combinatie van kwaadwillende islamitische reactionairen en een onontwikkelde, manipuleerbare bevolkingsmassa motiveert hard-line-kemalisten in Turkije tot op de dag van vandaag. 
De harde anti-islamitische politieke koers werd ook na de dood van Atatürk in 1938 door zijn opvolgers voortgezet, tot het einde van de Tweede Wereldoorlog dit om verschillende redenen onmogelijk maakte.

\subsubsection{TWEE INTERPRETATIES VAN SECULARISME}

Vrijwel onmiddellijk na het einde van de Tweede Wereldoorlog in Europa gaf Atatürks opvolger als president en partijleider, İsmet İnönü, signalen dat Turkije de weg naar de democratie zou inslaan. Hiervoor waren zowel externe als interne oorzaken. Turkije was vrijwel de hele oorlog neutraal gebleven, maar had zich helemaal aan het einde aangesloten bij de Verenigde Naties (VN) en had ook het handvest van de VN ondertekend. Vanaf 1946 was duidelijk dat Turkije te maken kreeg met grote druk van de kant van de Sovjet-Unie die het niet zonder hulp zou kunnen weerstaan. Met de afkondinging van de 'Truman-doctrine' in 1947 en het beschikbaar komen van 'Marshallhulp' waren de Verenigde Staten Turkije's belangrijkste politieke en economische partner geworden en was het voldoen aan Amerikaanse eisen op het gebied van democratisering en economisch liberalisme van levensbelang geworden. Tegelijk had zich ook intern veel spanning opgebouwd in de oorlogsjaren, die voor de meeste mensen vooral jaren van autoritaire onderdrukking en verarming waren geweest.

Vanaf 1946 werd Turkije een meerpartijendemocratie en dat had onmiddellijk gevolgen voor de relatie tussen de staat en de islam. Competitie om de steun van de kiezers werd nu belangrijk en die kiezers woonden nog steeds voor meer dan driekwart op het platteland. Daar en in de kleine provinciesteden domineerde een conservatieve, sterk religieuze wereldvisie die door de kemalistische culturele revolutie nauwelijks was geraakt. Op zoek naar de steun van de massa van de bevolking gaf de regering wat meer ruimte aan de islam. Islamitisch onderwijs op school werd, zij het voorlopig facultatief, heringevoerd en de theologische faculteit werd heropend. Er kwamen weer enkele opleidingen voor predikers en voor het eerst in een generatie konden er in 1948 weer enkele Turken op pelgrimstocht naar Mekka. Het laatste kabinet onder het kemalistische regime (1949-1950) werd zelfs geleid door Şemsettin Günaltay, een hoogleraar in de islamitische theologie.

Het mocht niet meer baten. In de ogen van de bevolking was de draai van de Republikeinse Volkspartij, die tenslotte 25 jaar lang voor autoritair en secularistisch beleid had gestaan, niet geloofwaardig en de verkiezingen van mei 1950 gaven een grote meerderheid aan de oppositie van de Democratische Partij onder leiding van Adnan Menderes. In tegenstelling tot de Republikeinse Volkspartij ontleende de Democratische Partij haar macht aan de steun van lokale netwerken, die zich in de jaren vijftig bewust werden van de waarde van hun steun. Dit maakte de partij gevoelig voor de behoeften en percepties die onder de bevolking leefden. De Democratische Partij en haar opvolgers zijn er daarom door seculiere kringen in Turkije vaak van beschuldigd religie politiek uit te buiten en Atatürks erfenis op de tocht te zetten. Dit is echter hooguit een halve waarheid. 
Het is waar dat Menderes concessies deed aan de religieuze gevoelens van de bevolking. Een van de eerste dingen die hij deed, was het weer toelaten van de gebedsoproep in het Arabisch. Daarnaast werd het religieus onderwijs op school uitgebreid en kwamen er meer opleidingen voor voorgangers en predikers. De verkoop van religieuze literatuur werd toegestaan en bij de verkiezingen zocht de Democratische Partij de steun van religieuze bewegingen zoals de Nurcus (par. 2.2.6). Toch werd aan het seculiere karakter van de staat en de wetgeving in het geheel niet getornd. Er was geen sprake van een terugkeer naar islamitische wetgeving of van het loslaten van de staatscontrole op de moskeeën en moefti's. Toen in 1950 een groep radicale religieuze activisten van de Ticani-derwisjorde Atatürk-bustes aanviel, werd onmiddellijk een strenge wet ter verdediging van de nagedachtenis van Atatürk door het parlement gejaagd (Zürcher 1995: 285-7; Yavuz 2003: 61-2). De reactie van Menderes en de zijnen op de constante beschuldigingen van de kant van de Republikeinse Volkspartij dat zij het secularisme ondermijnden, was heel expliciet. Tegenover de kemalistische visie, die secularisme voorstelde als een verdedigingsmechanisme dat de vrijheid van denken moest waarborgen tegenover de islam, stelden zij een secularisme dat de vrijheid van geloof van de burgers moest waarborgen. Secularisme diende niet antireligieus te zijn en diende beperkt te blijven tot de staatsordening.

Ondanks herhaald ingrijpen van het Turkse leger in de politiek, vooral via de staatsgreep van mei 1960 en de 'coup per memorandum' van maart 1971, maar ook nog via een aantal waarschuwingen en demonstraties tussendoor, bleef de stroming die Menderes had vertegenwoordigd ook in de jaren zestig en zeventig de dominante politieke macht in het land. Vanaf 1965 wist de opvolger van de Democratische Partij, de Gerechtigheidspartij van Süleyman Demirel, het grootste deel van de voormalige aanhangers van de Democratische Partij aan zich te binden. De politiek ten opzichte van de islam van deze grote conservatieve volkspartij bleef in grote trekken gelijk aan die van Menderes. Demirel stelde bij herhaling dat de staat weliswaar seculier was en diende te blijven, maar dat dit niet betekende dat het individu ook seculier diende te zijn. Islam werd positief gewaardeerd als een morele code die kracht gaf aan de Turkse samenleving. In de jaren van de Koude Oorlog zagen de meer conservatieve politici islamitische normen en waarden, naast kemalistisch nationalisme, zelfs als een noodzakelijk tegengif tegen de dreiging van socialisme en communisme. Religieuze bewegingen profiteerden hiervan om zo nog meer geïntegreerd te raken met de 'mainstream' van de Turkse politiek (Yavuz 2003: 62).

\subsubsection{ISLAM IN DE POLITIEK EN DE 'STAATSISLAM'}

Naast de toenemende aandacht van niet-religieuze partijen voor de islam, zien we vanaf de jaren zestig ook de opkomst van uitgesproken islamitische, of islamistische, politieke bewegingen. Dat wil zeggen, van bewegingen die hun politieke programma (mede) baseren op de richtlijnen van de islam. De nieuwe grondwet die in 1961 in Turkije was ingevoerd, bood ruimte voor islamistische politieke bewegingen. 
De opkomst van een islamistische politieke beweging was geen gevolg van grotere vroomheid onder de bevolking, maar van de sociaal-economische ontwikkelingen van de jaren zestig. Het waren de jaren waarin in Turkije enerzijds een grote en sterke industriële sector werd opgebouwd en anderzijds een serieuze en vaak militante arbeidersbeweging van de grond kwam. De esnaf (kleinere ondernemers) herkenden zich steeds minder in de politiek van de grote partijen, die zich sterk oriënteerden op de grote zakensector (zoals de Gerechtigheidspartij) of de ambtenaren en de georganiseerde arbeiders (zoals de Republikeinse Volkspartij). Eind jaren zestig slaagden de kleine ondernemers erin de macht binnen de Unie van Kamers van Koophandel van Turkije over te nemen van de grootindustriëlen uit Istanbul. Hun vertegenwoordiger werd voorzitter. Het was Necmettin Erbakan, een deels in Duitsland opgeleide hoogleraar machinebouw aan de Technische Universiteit van Istanbul, die in 1969 als onafhankelijke afgevaardigde van het conservatieve Konya in het parlement werd gekozen. In 1970 richtte hij samen met enkele andere parlementariërs de Nationale Orde Partij op, die echter op grond van antiseculiere activiteiten werd verboden toen het Turkse leger in maart 1971 achter de schermen de macht overnam. In 1973 werd Erbakan voorzitter van een nieuwe partij, of liever, de oude partij met een nieuwe naam: de Nationale Heilspartij. In deze partij speelden leden van religieuze broederschappen, met name die van een tak van de Nakşibendis (par. 2.2.4), een leidende rol. Ook Erbakan behoorde en behoort tot deze orde.

De ideologie van Erbakans partij werd sinds 1973 aangeduid als de 'Nationale Visie' (Milli Görüş). Het programma omvatte typische islamistische punten, zoals de nadruk op ethiek en moraal in onderwijs en opvoeding en de bestrijding van woeker en corruptie, maar verrassend genoeg werd in het Nationale Visieprogramma ook het secularisme sterk benadrukt. Vrijheid van geweten en van meningsuiting werden als basis van de democratie en de mensenrechten aangemerkt. Het begrip secularisme werd echter in een andere zin geïnterpreteerd dan bij de kemalisten het geval was. Bedoeld werd volledige vrijheid van godsdienst, zonder staatscontrole. Het kemalistische secularismebegrip werd afgedaan als 'dictatuur van de ongelovigen'. Opheffing van de artikelen in strafwetgeving en grondwet die politiek gebruik van religie strafbaar maakten, stond dan ook vanaf het begin hoog op Erbakans agenda (Erbakan 1975).

In het grillige klimaat van de jaren zeventig, met toenemende arbeidsonrust en politieke en maatschappelijke ontwrichting als gevolg van de economische crisis, bleek de Nationale Heilspartij aantrekkelijk voor een flink deel van het traditioneel georiënteerde electoraat. Bij de verkiezingen van 1973 haalde de partij zo'n twaalf procent van de stemmen en was vervolgens onmisbaar om coalities aan een meerderheid te helpen. Deze macht gebruikte de partij vervolgens om in 'haar' ministeries op alle strategische posities partijgenoten te zetten.

De deelname van de partij aan de gevestigde politiek betekende dat zij in de ogen van de kiezers ook medeverantwoordelijk was voor het falende beleid, dat noch aan de economische crisis, noch aan het politieke geweld op straat een einde wist 
te maken. Bij de verkiezingen van 1977 bleek de aanhang van de partij dan ook tot onder de negen procent geslonken. De greep van de activisten van de Nationale Heilspartij op delen van het staatsapparaat was echter ongebroken. Na de militaire staatsgreep van september 1980 werd Erbakans partij, samen met alle andere politieke organisaties, verboden. Erbakan werd vervolgd, maar uiteindelijk vrijgesproken. In de jaren na 1980 verschoof het centrum van de activiteiten van de partij naar Europa, waar de aanhangers van de Nationale Visie veel meer bewegingsruimte hadden dan in Turkije zelf (Zürcher in Driessen (red.) 1997: 365-7).

De andere islamitisch-politieke stroming die in de jaren zeventig en tachtig veel invloed kreeg, was de zogeheten 'Turks-Islamitische Synthese'. Deze ideologie was in de jaren zeventig systematisch uitgewerkt door de auteur İbrahim Kafesoğlu. De ideologie ging ervan uit dat de islam voor de Turken een bijzondere aantrekkingskracht had, aangezien de oorspronkelijke islam van de profeet Mohammed en de cultuur van de Centraal-Aziatische Turken erg veel op elkaar leken. Ze hadden een groot gevoel voor rechtvaardigheid gemeen, monotheïsme, een geloof in de onsterfelijke ziel en gehechtheid aan familie en fatsoen. De missie van de Turken was dan ook om bij uitstek de 'soldaten van de islam' te zijn. De islam was dus voor de aanhangers van deze ideologie, net als voor de Nationale Visie, een onlosmakelijk deel van de moderne Turkse cultuur.

De Turks-Islamitische Synthese werd eerst omhelsd door een organisatie die zich de 'Haardvuren van de Verlichte Geesten' (Aydın Ocakları) noemde. Dit was een in 1970 door leidende figuren uit het bedrijfsleven, de universiteit en de politiek opgerichte club die als doel had de linkse intellectuelen, die het politieke en ideologische debat van die jaren beheersten, met hun eigen wapens (symposia, forums, publicaties) te bestrijden. Ondanks de secularistische kemalistische tradities van het Turkse officierskorps waren er ook in het leger nogal wat mensen in deze beweging geïnteresseerd. In de tweede helft van de jaren zeventig werd de ideologie van de synthese ook populair onder de aanhangers van de Nationalistische Actiepartij, die in 1969 uit een andere splinterpartij was voortgekomen. Deze partij was een rechts-radicale partij, geleid door een ex-kolonel, Alpaslan Türkeş, en vond haar aanhang vooral onder conservatieve soennitische Turken in de brede gordel dwars door Anatolië, waar de bevolking sterk gemengd is (Turks versus Koerdisch en soennitisch versus alevitisch). In de eerste jaren van haar bestaan propageerde de partij een ultranationalistische variant van het kemalisme, maar midden jaren zeventig kreeg de Turks-Islamitische Synthese de overhand.

Meer dan de Nationale Heilspartij van Erbakan wist de Nationalistische Actiepartij van Türkeş aanhang te verwerven onder de slecht opgeleide en arme jeugd van de sloppenwijken in de grote steden. Zij vormden de voedingsbodem voor de jeugdstormachtige commando's die onder de naam 'Idealisten' (Ülkücü), getooid met hun embleem van de Grijze Wolf, de straten op linkse activisten veroverden. Ook Türkeş’ partij werd na de staatsgreep van september 1980 verboden. Türkeş 
werd, net als Erbakan, vervolgd, maar uiteindelijk vrijgesproken (Zürcher in Driessen (red.) 1997: 367).

De junta die in september 1980 onder leiding van generaal Kenan Evren, zelf de zoon van een imam, de macht overnam, liet het niet bij het verbieden van onder andere de twee bovengenoemde religieus georiënteerde partijen. Ze ontketende daarnaast een alomvattend ideologisch offensief, waarin de islam een centrale plaats innam. De officieel goedgekeurde islam die door de militairen werd gepropageerd, had veel overeenkomsten met de Turks-Islamitische Synthese en enkele toonaangevende leden van de Haardvuren van de Verlichte Geesten speelden een hoofdrol in de vormgeving van de nieuwe ideologie (Yavuz 2003, 71-73). Deze had een sterk nationalistisch karakter, benadrukte de band tussen staat en natie, nationale eenheid en maatschappelijke harmonie en verheerlijkte militaire en autoritaire waarden. Daarnaast werd de islam voorgesteld als een 'verlichte' religie, open voor wetenschap en technologie (Evren 1986: 221). Het doel van dit ideologische offensief was de Turkse jeugd immuun te maken voor zowel socialistische propaganda als voor de verlokkingen van niet door de staat gecontroleerde, radicale islamitische bewegingen.

De islamisering van de staatsideologie bracht ook de noodzaak met zich mee van een radicale herinterpretatie van de erfenis van Mustafa Kemal Atatürk. Die werd nu voorgesteld als een hervormer van de islam. Secularisme werd geïnterpreteerd als een noodzakelijke stap om de islam te zuiveren en een 'ware islam' tot stand te brengen (Yavuz 2003: 70-1).

Vanaf 1982 is deze 'staatsislam' vooral via het onderwijs gepropageerd. Hij vormde de basis van het Nationale Cultuurrapport van het Staats Plan Bureau uit 1983 (Poulton 1997: 184). Lessen in godsdienst en ethiek werden voor alle klassen verplicht en ook de staatsmedia (radio en televisie) verbreidden de boodschap. Het Presidium voor Religieuze Zaken bleef evenzeer een aan de staat gelieerd orgaan als daarvoor het geval was geweest, maar zijn bestaan en taken werden in 1982 ook in de grondwet vastgelegd. In die taken was de nauwe verbinding die nu tussen religie en nationalisme werd gepropageerd terug te vinden. Het presidium had als taak "de Turkse nationale identiteit te beschermen." Deze zinsnede was direct ontleend aan het oorspronkelijke programma van Kafesoğlu (Poulton 1997: 185-7). In materieel opzicht voer het presidium wel bij de nieuwe politieke lijn: het aantal personeelsleden groeide van 50.765 in 1979 naar 84.172 tien jaar later. Dat de zorg voor de verspreiding van 'correcte' islam zich niet beperkte tot Turkije, blijkt uit het aantal in Europa werkzame stafleden van het presidium. Dat ging in deze jaren van 20 naar 628 (Poulton 1997: 185-7).

Het is curieus te constateren dat de instrumentalisering van de islam als ideologisch wapen in dienst van de staat door de militairen en hun opvolgers in de jaren tachtig van de twintigste eeuw sterk doet denken aan de politiek van sultan Abdülhamit II exact een eeuw eerder. 


\subsubsection{ISLAMISTISCHE DOORBRAAK EN KEMALISTISCH REVEIL}

De islampolitiek van de militairen na 1980 is vaak beschreven als de wegbereider van de islamistische doorbraak van Erbakans in 1983 als Welvaartspartij heropgerichte partij in de verkiezingen van 1994 en 1995 (Sunier 1998: 23-4). Het idee hierachter is dat je, wanneer je eenmaal de deur voor de islam openzet, niet meer kunt kiezen welke islam daardoor binnenkomt. Demografische ontwikkelingen hebben daar echter zeker zoveel mee te maken gehad. De jaren tachtig en vroege jaren negentig waren een periode van ongekende migratie naar de grote steden van Turkije. Een stad als Istanbul verdubbelde in deze tijd in omvang en de nieuwe migranten vormden de meerderheid van het stedelijke electoraat. De migranten waren voor het opbouwen van een bestaan in de nieuwe omgeving sterk afhankelijk van particuliere netwerken en de mystieke broederschappen (par. 2.2), die dwars door alle sociale lagen heen netwerken vormden en bij uitstek in staat waren de nieuwkomers aan werk, huisvesting of brandstof te helpen. Het was logisch dat de migranten die in deze netwerken werden opgenomen ook het stemadvies van de leiders ervan volgden.

Zoals we aan het begin van dit hoofdstuk hebben gezien, leidde de doorbraak van de Welvaartspartij niet alleen tot grote paniek bij het seculiere establishment van Turkije in 1994-'95, maar ook tot krachtdadig ingrijpen van het leger. Na de val van Erbakan in 1997 en de ontbinding van de Welvaartspartij, een jaar later, reorganiseerden de parlementariërs van de partij zich als de Partij van de Deugd. Tegen alle verwachtingen in deed deze partij het relatief slecht in de nationale verkiezingen van april 1999. Ze slaagde er niet in de woede onder de aanhang van de oude Welvaartspartij te mobiliseren en eindigde op de derde plaats. Dit slechte resultaat leidde uiteindelijk tot de al langer verwachte splitsing binnen de islamistische beweging van de Nationale Visie. De oude garde, de kring van Necmettin Erbakan, werd sterk gedomineerd door leden van de Nakşibendi-broederschap en hield vast aan een zeer religieus getint programma (par. 2.2.4). Toen ook de Partij van de Deugd in juni 2001 werd verboden, herstichtten zij de partij als de Partij van de Gelukzaligheid. De jongere garde van de partijleiders, onder wie Recep Tayyip Erdoğan (de voormalig burgemeester van groot-Istanbul) en Abdullah Gül, zag dit als een doodlopende weg. Zowel omdat zij zich realiseerden dat een strikt islamistische partij door het staatsapparaat nooit als regeringspartij zou worden geaccepteerd (de les van februari 1997), alsook omdat zij inschatten dat een dergelijke partij niet meer dan rond de twintig procent van het Turkse electoraat aansprak. In augustus 2001 richtten zij de Partij voor Gerechtigheid en Ontwikkeling (Adalet ve Kalkınma Partisi ofwel Ak-partij) op. Deze partij positioneerde zich uitdrukkelijk als een brede conservatieve partij met respect voor islamitische waarden en normen, maar zonder een uitdrukkelijk religieus programma. Het 'Gerechtigheid' in de partijnaam herinnerde ook uitdrukkelijk aan de Gerechtigheidspartij, de brede conservatieve volkspartij die tussen 1961 en 1980 als rechtse massapartij de fakkel van de Democratische Partij van Menderes had overgenomen. 
Intussen was sinds de islamistische doorbraak van 1994-1995 ook een tegenbeweging ontstaan. De val van Erbakan was weliswaar grotendeels het werk van de legerleiding geweest, maar mede op instigatie van die legerleiding ontstond in de jaren die volgden ook een brede burgerlijke Atatürkçülük-beweging ('atatürkisme'). Dit was een defensieve beweging die de veiligheid van het land bedreigd zag door de militante islam en Koerdisch separatisme en daarachter vaak de hand van duistere 'buitenlandse machten' vermoedde die op de opdeling van Turkije uit waren. De aanhangers van de beweging keken voor 'redding' naar de staat en met name naar het leger en eisten voortdurend dat er maatregelen ter verdediging van het secularisme genomen zouden worden.

De houding van deze stroming tegenover democratie en mensenrechten is ambivalent. Om de dreiging van een islamitische machtsovername of de opdeling van Turkije te voorkomen, vertrouwt men op de 'sterke staat' en is men over het algemeen bereid een beperking van de democratie voor lief te nemen. Pluriformiteit wordt al snel als zwakte gezien (Yavuz 2003: 263). Atatürkisten uit deze richting zijn er vaak van overtuigd dat de islam, anders dan het christendom, niet binnen een democratisch seculier systeem te domesticeren is. Onder de actiefste en grootste burgerorganisaties van dit type waren (en zijn) de Vereniging voor het Atatürkistische Denken (Atatürkçü Düşünce Derneǧi) en de Vereniging voor Steun aan de Moderne Levenswijze (Çağdaş Yas amı Destekleme Derneği) de belangrijkste. In de kringen van dit burgerlijk atatürkisme werd zeer negatief gedacht over de coup van 12 september 1980 en zijn erfenis: de verbreiding van de Turks-Islamitische Synthese. De junta van 1980 wordt gezien als een groep 'valse kemalisten' die het fundamentalisme door de achterdeur hebben binnengelaten (Erdoğan in Yerasimos et al. (ed.) 2000: 251-2; 277-8).

Interessant genoeg bedienen zowel de islamisten als deze atatürkisten zich van een oppositiediscours. Beide bewegingen zien zichzelf als de zwakkere partij die vecht voor een goede zaak. De islamisten zien zichzelf als de slachtoffers van een almachtige en onrechtvaardige staat, de atatürkisten hebben als beeld dat Atatürks erfenis is verkwanseld en 'echte' atatürkisten geen toegang meer hebben tot de politieke macht (Erdoğan in Yerasimos et al. (ed.) 2000: 251-2; 2612).

In de jaren van de kemalistische restauratie na februari 1997, en zeker na de verkiezingen van 1999 leken de staatsgeoriënteerde secularisten in Turkije aan de winnende hand, maar interne conflicten binnen de regerende coalitie maakten nieuwe verkiezingen in 2002 onvermijdelijk. Deze leidden tot een politieke aardverschuiving. De eerdergenoemde AK-partij haalde meer dan 34 procent van de stemmen en daarmee, door de eigenaardigheden van het Turkse kiesstelsel, tweederde van de zetels in het parlement. Deze overwinning was zo groot dat een regering zonder de AK-partij onmogelijk was geworden, een fait accompli dat ook door het staatsapparaat werd geaccepteerd. 
Sinds de verkiezingen van 2002 en het aan de macht komen van de AK-partij onder Erdoğan hebben we in Turkije te maken met een bipolair systeem. Staatsapparaat en regeringspartij hebben elk een fundamenteel andere opvatting over wat secularisme is. De staat, gesteund door de secularistische oppositie en de eerdergenoemde atatürkistische burgerbewegingen, zoekt aansluiting bij de tradities van de jaren dertig en veertig, waarbij secularisme als een schutswal wordt gezien die de vrijheid moet beschermen tegen islamitische reactie. De regeringspartij sluit op haar beurt meer aan bij de tradities van Menderes, Demirel en Özal (de stichter van de Moederlandpartij in 1983) en vindt dat ook een seculiere staat gelovige individuen de ruimte moet geven hun normen en waarden te uiten.

Herstel van de zware financieel-economische crisis van 2001 en de pogingen het lidmaatschap van de EU te verkrijgen, geven staat en politiek momenteel een gezamenlijk belang om het verstandshuwelijk te laten werken. Met name de AKpartij heeft veel te winnen bij het doorvoeren van de hervormingsmaatregelen die nodig zijn om Turkije aan de zogenaamde 'Kopenhagen-criteria' van de EU te laten voldoen. Deze hervormingen tenderen er immers naar om macht weg te halen bij de staat en over te hevelen naar maatschappelijke spelers. Er zijn echter voortdurend irritaties die de symbiose bedreigen. Deze treden met name op rond de fenomenen die door de geschiedenis van de secularisatie en de reactie daarop tijdens de republiek een symbolische waarde hebben gekregen: kwesties als de kledingvoorschriften (en het verbod op de hoofddoek) in het onderwijs en binnen het staatsapparaat waarover al bijna twintig jaar een onafgebroken fel politiek debat woedt (Göle 1996).

\subsection{OFFICIËLE DOCTRINE VERSUS TARIKATS EN NEO- BEWEGINGEN}

\subsubsection{MYSTIEKE ORDES EN DE ACTUALITEIT}

Sinds 1925 zijn in Turkije de islamitische mystieke broederschappen (tarikats) opgeheven en verboden. Hun bezittingen werden overgedragen aan de staat. Toch is er iets vreemds aan de hand. Wie bijvoorbeeld het graf van de mystieke heilige Celaleddin Rumi in Konya wil bezoeken, kan dat als toerist rustig doen. Graag zelfs, want het complex is een museum dat onder het Turkse ministerie van Cultuur valt. Eenmaal binnen in het complex valt het de bezoeker op dat talloze Turkse bezoekers, voornamelijk vrouwen, bezig zijn met een pelgrimage. Op deze plek lijken vroomheid en commercie hand in hand te gaan. Om en nabij het museum zijn niet alleen teksten van Rumi maar ook vele andere 'Rumisnuisterijen' te koop. Ook de rituele dans van de Mevlevi-derwisjen wordt regelmatig als toeristische attractie opgevoerd in bijvoorbeeld een lokale sporthal. Tekenen van vroomheid zijn op plaatsen zoals deze alomtegenwoordig: votieven worden achtergelaten, bezoekers zijn soms in extase en lopen rond met tranen in de ogen (Shankland 1999: 67). 
Bijna tachtig jaar na hun opheffing zijn de verschillende mystieke ordes nog bijna dagelijks in het nieuws. Vooral sinds het midden van de jaren negentig staan de kranten vol met alarmerende berichten over de activiteiten van religieuze netwerken en met name over hun infiltratie in het staatsapparaat. Dit roept de vraag op hoe de derwisjordes de seculariseringsmaatregelen in Turkije hebben overleefd en welke rol zij in het huidige islamitische landschap spelen.

\subsubsection{ISLAMITISCHE MYSTIEK}

Hoewel de islam, net als het jodendom, in eerste instantie een systeem van normen, waarden en regels is, waarvan de moslim gelooft dat zij door God zijn geopenbaard en dat het leven volgens de geboden van Gods wet (de şeriat) het eerste vereiste is voor de goede gelovige, is er ook binnen de islam al vroeg de behoefte ontstaan aan een directere, meer persoonlijke en emotionelere geloofservaring dan alleen het volgen van de wet mogelijk maakt. Zo is de islamitische mystiek (tassavuf of soefisme) ontstaan. Doel van de mysticus is voorbij de şeriat te gaan om op die manier de goddelijke werkelijkheid (hakikat) op persoonlijke wijze te ervaren. De weg die het individu moet afleggen om dit te bereiken, en die langs vele tussenstadia loopt, wordt door de mystici aangeduid als de tarikat (weg).

In de bekering van de Turkse volkeren van westelijk Centraal-Azië tot de islam, nog voor zij naar het Midden-Oosten migreerden, speelden rondtrekkende mystieke predikers en heilige mannen een leidende rol en de invloed van de mystiek is onder de Turken ook altijd groot gebleven. De populariteit van de mystici was zeker ten dele te danken aan het feit dat zij de volkstaal gebruikten en niet, zoals de schriftgeleerden van de islam, het Arabisch.

De islamitische mystiek beleefde een enorme bloei in de periode die voor het Midden-Oosten juist een tijd van crisis was: de periode van de invallen van de Mongolen en van de kruistochten (1200-1300 n. Chr.). In die periode veranderde ook de manier waarop de mystieke islam was georganiseerd. Waren mystici tot dan toe vooral individueel of in kleine groepen met hun geloof bezig geweest, in deze periode kwamen persoonlijkheden naar voren die door grote groepen volgelingen als hun meester (mürşid of şeyh, verder: 'sjeik') werden erkend. Hoewel de meeste van deze sjeiks helemaal niet de intentie hadden een school te vestigen, organiseerden de volgelingen van deze leermeesters zich geleidelijk aan in mystieke orden of broederschappen, waarbij de leermeester als stichter werd aangemerkt. De benaming tarikat raakte in de loop der tijd vooral in zwang als aanduiding van de broederschappen die zichzelf beschouwden als de geestelijke nazaten van een en dezelfde leermeester. Het is in deze betekenis dat de term vandaag de dag nog in Turkije wordt gebruikt. 
In het Osmaanse rijk waren vele soefi-ordes actief. Sommige daarvan hadden hun oorsprong in Centraal-Azië, andere in Anatolië, weer andere in de Arabische wereld. Kenmerkend voor alle stromingen was dat zij intuïtief inzicht in de goddelijke waarheid (marifet) veel hoger waardeerden dan de kennis van het geloof die door wetenschap (ilim) te verkijgen is. Desalniettemin werd er, ook door veel mystici zelf, belang aan gehecht om aan te kunnen tonen dat de mystiek in het geheel niet in strijd was met de orthodoxe soennitische leer, ook al deden de leefwijze en bepaalde rituelen van sommige mystici of broederschappen anders vermoeden.

De mysticus die de eenheid met God wil bereiken, kan dat doen door zelfverloochening en volledige overgave aan God, waarbij dan vervolgens een reeks niveaus doorlopen dient te worden. De broederschappen kenden en kennen daarnaast ook ieder hun eigen kenmerkende geestelijke en lichamelijke oefeningen die dit eenwordingsproces moeten bespoedigen. Deze worden zikir genoemd, letterlijk: 'het gedenken' (van Gods naam). De zikir kan allerlei verschijningsvormen aannemen: van een eenvoudig, al dan niet in stilte herhalen van het eerste deel van de geloofsbelijdenis ('Er is geen god dan God/Allah') tot bijvoorbeeld de befaamde muziek en dans waarmee de Mevlevi-derwisjen proberen op te gaan in God (Buitelaar en Ter Haar (red.) 1999: 9-17).

In het Osmaanse rijk speelden de tarikats een zeer belangrijke rol als kanalen tussen de bevolking, zowel van stad als platteland, en de staat. De leiders van lokale derwisjkloosters (tekkes) hadden vaak een grote autoriteit, die hen in staat stelde lokale conflicten door bemiddeling op te lossen. In een maatschappij waar de kloof, in termen van cultuur, macht en rijkdom, tussen de regerende elite en de massa van de bevolking enorm was en waarin dat onderscheid voortdurend als een kernelement van de 'orde van de wereld' werd benadrukt, vormden de broederschappen een van de weinige kanalen die dwars door de sociale gelaagdheid heen gingen. Verreweg de meeste leden van de tarikats waren geen 'fulltime mystici', maar lekebroeders die het lidmaatschap combineerden met een maatschappelijke functie, uiteenlopend van sjouwer, winkelier of beroepsmilitair tot gouverneur. Daarnaast waren vele godsdienstgeleerden tegelijk ook mysticus (Zürcher 1995: 17). De hiërarchie binnen de orde, die gebaseerd was op de mate van mystieke verlichting en inzicht die een individu had bereikt, kon de maatschappelijke hiërarchie gebaseerd op positie en status dus geheel doorkruisen.

De Osmaanse sultans systematiseerden en organiseerden de broederschappen zoals zij ook de oelema op een tot dan toe in het Midden-Oosten ongekende manier in een hiërarchisch en gecontroleerd systeem hadden ondergebracht. De paradox die we bij de Osmaanse officiële islam aan het werk hebben gezien, werkte ook voor de mystieke broederschappen: de Osmanen incorporeerden de broederschappen tot op zekere hoogte in het staatsapparaat, waardoor zij controle konden uitoefenen, maar waardoor ook de invloed van de broeder- 
schappen in de staat, tot in de hoofdstad toe, kon groeien (Mardin 1989: 183-5). De sultans zelf en veel van de hoogste staatsfunctionarissen associeerden zich openlijk met een of meer van de tarikats en in iedere belangrijke stad werd een 'hoofd der broederschappen' (şeyh al-turuk) aangesteld, die tegenover de staat verantwoordelijk was voor het gedrag van de georganiseerde mystici (Geoffroy in EI2, vol. X: 243-6).

De Osmaanse sultans van de negentiende eeuw, van Mahmut II (r. 1808-1839) tot Abdülhamit II (r. 1876-1909), positioneerden zich allemaal in de eerste plaats als voorvechters van de soennitische orthodoxie, maar zij zagen tegelijk in dat de mystieke broederschappen onontbeerlijk waren voor het creëren van een draagvlak onder het volk. Soefisjeiks werden door het hof actief gebruikt voor propagandadoeleinden. Daarbij was en bleef staatscontrole, ook over deze tak van de religie, van het grootste belang. Sultan Mahmut stichtte het ministerie voor Vrome Stichtingen dan ook met name om de benoeming van de lokale tekkesjeiks centraal in de hand te kunnen houden (Abu Manneh 1979: 138; Deringil 1998: 63-6).

In de negentiende en vroege twintigste eeuw lijken de mystieke broederschappen nog meer aan belang en populariteit gewonnen te hebben. Dit kan worden gezien als een deel van de islamitische reactie tegen de Europese economische, politieke en culturele penetratie van die periode (Zürcher 1995: 235). Ook is er wel op gewezen dat door de negentiende-eeuwse Osmaanse hervormingen, en die van de kemalistische republiek, het traditionele patrimoniale systeem, dat gebouwd was op persoonlijke verhoudingen tussen patroon-cliënt, depersonaliseerde en werd vervangen door formele, contractuele relaties van het westerse type. Binnen de netwerken van de orden, waar juist de persoonlijke band tussen de leermeester en de leerling centraal stond, bleven de oude codes wel intact (Mardin 1989: 10-13).

\subsubsection{DE NAKŞIBENDI-ORDE}

Van alle soefibroederschappen die in het Osmaanse rijk en Turkije actief zijn geweest, is de belangijkste rol ongetwijfeld weggelegd voor de Nakşibendi-orde. Deze orde voert terug naar Bahaeddin Nakşbend, die in de veertiende eeuw in Bukhara, in het tegenwoordige Oezbekistan, actief was. In de vijftiende en zestiende eeuw verspreidde de orde zich door heel Centraal-Azië en bereikte zij ook het Indische subcontinent. In India ontstond binnen de orde in de achttiende eeuw een vernieuwingsbeweging, die ook de Osmaanse gebieden bereikte in de vorm van de prediking van Mevlana Khalid Baghdadi (1776-1827).

Geïnspireerd door de ontwikkelingen in India, voerde Khalid twee belangrijke vernieuwingen door, die vervolgens kenmerkend werden voor de Nakşibendibeweging in het Osmaanse rijk: de verplichte retraite voor novicen en de doctrine van de rabita, de onverbrekelijke geestelijke band tussen de meester en zijn leerling. Dit waren natuurlijk veranderingen die de discipline en cohesie 
binnen de orde zeer bevorderden. De Khalidi-versie van de Nakşibendi-leer werd al snel volledig dominant in de Osmaanse gebieden. Deze versie van de Nakşibendi-orde plaatste zichzelf nadrukkelijk aan de kant van de soennitische orthodoxie en benadrukte het belang van gehoorzaamheid aan de regels van de heilige wet. Over het algemeen kan dan ook gezegd worden dat deze zeer invloedrijke derwisjorde zich richtte tegen de westers georiënteerde hervormingen van de periode van de Tanzimat (hervormingen) (1839-1871) en later tegen die van de Jong Turken. Ze was daarentegen nauw verbonden met de islampolitiek van sultan Abdülhamit II (Zarcone in EI2, vol. X: 332-4).

\subsubsection{HET KEMALISTISCHE OPTREDEN TEGEN DE ORDES}

Twee jaar na de uitroeping van de Republiek Turkije besloot het parlement in Ankara op 30 november 1925 bij wet 677 tot de opheffing van de derwisjordes. De centra van de ordes, de tekkes, werden gesloten en overgedragen aan de staat. Dit besluit was in de eerste plaats ingegeven door het antiklericalisme van de kemalisten, voor wie de mystieke sjeiks, meer nog dan de oelema, symbool stonden voor achterlijkheid. Een tweede belangrijke reden was ongetwijfeld dat de wijdverbreide netwerken van de mystieke ordes, met hun hechte structuur en gehoorzaamheid aan het gezag van de religieuze voormannen, concurrerende machtscentra vormden die de kemalistische staat niet wilde accepteren.

De ordes hadden geen andere keuze dan zichzelf inderdaad op te heffen, zich te verzetten of ondergronds te gaan. Verzet was er, zeker in de vroege jaren van de republiek, maar het bleef bij tamelijk geïsoleerde incidenten. In sommige gevallen, zoals bij de moord op reserveofficier Kubilay in Menemen in 1930, werd zo'n incident wel aangegrepen voor grootschalige vervolgingen, in dit geval van de Nakşibendis. Ondergronds gaan was voor sommige ordes veel gemakkelijker dan voor andere. De Nakşibendis, leden van de meest verbreide derwisjorde, hadden het gemakkelijk, omdat zij geen uitgebreid ritueel kenden met muziek en dans en hun bijeenkomsten dus ook in een huiskamer konden houden. Verschillende takken van de orde overleefden de jaren van de kemalistische eenpartijdictatuur (1925-1945) dan ook zonder al te veel problemen. De belangrijkste tak was die van de de İskenderpaşa-gemeenschap uit Istanbul, geleid door sjeik Mehmed Zahid Kotku (1897-1980), de 'geestelijke vader' van de Nationale Visie-beweging, die vanaf het eind van de jaren zestig onder zijn leerling Necmettin Erbakan actief werd in de Turkse politiek. Na Kotku's dood werd de gemeenschap geleid door zijn schoonzoon Mehmed Esat Coşan. Deze vluchtte na het militaire ingrijpen van februari 1997 naar Australië, waar hij in 2001 stierf. Na zijn dood werd hij als sjeik opgevolgd door zijn zoon Muharrem Nurettin Coşan, die nu nog steeds de leider is van deze invloedrijke en welvarende tak van de Nakşibendiorde (Yavuz 2003: 139-142).

Een belangrijke overlevingsstrategie van de Nakşibendis in de jaren van het felste kemalistische secularisme was dat zij actief functies probeerden te verwerven in de bureaucratie van het Presidium voor Religieuze Zaken, de Diyanet. Een aantal 
van hen verwierf hiermee invloedrijke posities, die uitgebaat konden worden toen na de overwinning van de Democratische Partij in 1950 meer tolerantie voor religieuze uitingen ontstond. Het verbod op de derwisjordes werd door Menderes weliswaar niet herroepen (zoals het ook later nooit is herroepen), maar in feite konden de mystieke sjeiks vanaf midden jaren vijftig wel weer meer en meer openlijk leidinggeven aan hun volgelingen, waarbij zij overigens voortdurend wantrouwend werden gevolgd door de bolwerken van het secularisme, zoals leger, openbaar ministerie en rechterlijke macht.

Zoals dat het geval is bij alle grote derwisjordes, splitste de Nakşibendi-orde zich in de loop der tijd ook in verschillende takken. Momenteel kent Turkije nog vijf takken die zichzelf tot de orde rekenen en die ook door de andere takken als zodanig erkend worden. Naast de al eerdergenoemde İskenderpaşa-gemeenschap is ook de Erenköy-gemeenschap zeer invloedrijk. Er zijn echter uit de Nakşibendi-orde ook bewegingen ontstaan die weliswaar veel van hun gedachtegoed aan deze orde ontlenen, maar die niet meer beschouwd kunnen worden als deel van deze broederschap. Hiermee betreden wij het terrein van de 'neo-bewegingen' of 'neo-tarikats'. Drie daarvan verdienen een aparte bespreking: de Nurcu-beweging (Volgelingen van het Licht), de Süleymancıs (aanhangers van Süleyman) en de uit de Nurcu-beweging voortgekomen Fethullahcılar (aanhangers van Fethullah).

\subsubsection{SAIT NURSî EN DE NURCU-BEWEGING}

Sait Nursî (1876-1960), door zijn aanhangers Bediüzzaman (Wonder van de tijd) genoemd, was een Koerdische Nakşibendi. Hij kwam uit een dorpsgemeenschap en had vrijwel geen formele scholing. Nursî had een ambivalente relatie met de Jong Turken gehad. Hij had deelgenomen aan de contrarevolutie van 1909, maar ook gediend als propagandist voor de regering in de Eerste Wereldoorlog. Hij had de nationale verzetsbeweging van Mustafa Kemal Pasja gesteund, maar waarschuwde al in 1923 voor de secularistische tendensen. Al voor 1908 had hij, met name in het zuidoosten van Anatolië, een reputatie opgebouwd als godsdienstgeleerde. Na de Koerdische 'Sjeik Sait-Opstand' van 1925 was hij met veel andere prominente Koerden gearresteerd en gedeporteerd, in zijn geval naar de stad Isparta, in het westen van het land. Vanaf de jaren twintig begon hij de ideeën die hij predikte ook vast te leggen in boeken en pamfletten, die later samen bekend werden als de Risale-i Nur - Külliyatı (Boodschap van het Licht Verzameld werk). In zijn werk riep hij moslims op om Gods ondeelbaarheid tot de basis van hun leven te maken, maar tegelijkertijd de moderne westerse wetenschap en techniek te bestuderen om deze voor de zaak van de islam te gebruiken. De gemeenschap van de moslims was in zijn ogen de enige echte basis voor maatschappelijke cohesie en hij wees daarom het nationalisme af. Oproepen om de islam op basis van diepe koranstudie te vernieuwen en zodanig aan te passen aan de moderne tijd dat materialisme en positivisme ermee bestreden konden worden, namen een belangrijke plaats in zijn werk in (Yavuz 2000: 7, 14). De verzamelde uitspraken van Sait Nursî gingen in veel verschillende rich- 
tingen, waren vaak voor velerlei uitleg vatbaar of zelfs duister, maar dat droeg juist bij aan hun brede aantrekkingskracht voor heel verschillende groepen mensen (Karpat in EI2, vol. VIII: 143-4).

Tussen 1935 en 1953 werd Sait Nursî meerdere keren gearresteerd en berecht voor het politieke gebruik van religie, maar hoewel hij inderdaad sociale mobilisatie predikte en zowel secularisme als nationalisme afwees, mengde hij zich niet direct in politieke kwesties. Gedurende de kemalistische periode waren zijn geschriften verboden, maar ze werden wel handmatig vermenigvuldigd door zijn groeiende kring van discipelen. Onder Menderes, die hij in de loop van de jaren vijftig steeds openlijker ging steunen, kreeg hij meer ruimte voor zijn prediking, maar zijn openlijke steun voor één politieke partij bevestigde in de ogen van de secularisten ook het schrikbeeld van het politieke misbruik van religie. Na zijn dood in 1960 bleef de Nurcu-beweging, zoals die nu heette, groeien en werd niet alleen invloedrijk in Turkije, maar ook onder de Turkse migranten in Europa (Zürcher 1995: 236-70).

Sait Nursî zag zijn beweging niet als een klassieke tarikat en zichzelf niet als een sjeik, maar als een imam (Karpat in EI2, vol. VIII: 143-4). Inderdaad is hij na zijn dood niet opgevolgd, zoals dat binnen een echte derwisjorde het geval zou zijn geweest. In plaats daarvan is de schriftelijke weergave van zijn boodschap, de Risale, de centrale plaats gaan innemen binnen de snelgroeiende gemeenschap van zijn volgelingen. Vanwege het belang van de tekst in hun beweging zijn de Nurcus zich ook met succes gaan toeleggen op druk en uitgeverij.

De politieke tegenstellingen in het Turkije van de jaren zeventig en tachtig leidden ook binnen de Nurcu-beweging tot splitsingen. Toen in 1970 vanuit kringen van de İskenderpaşa-gemeenschap de eerste echt islamistische politieke partij werd opgericht (Erbakans Nationale Orde Partij, later Nationale Heilspartij), steunde een deel van de Nurcus deze nieuwe partij, terwijl de meerderheid trouw bleef aan Süleyman Demirels Gerechtigheidspartij. Een ernstiger schisma vond plaats naar aanleiding van de militaire machtsovername van september 1980. Deze werd door enkele belangrijke Nurcu-voormannen, zoals Mehmet Kırkıncı in Erzurum en Fethullah Gülen in Izmir gesteund, maar door de zogenaamde Yeni Asya ('Nieuw Azië', een krant) groep, die de afgezette premier Demirel bleef steunen, heftig bestreden. Begin jaren tachtig kristalliseerde deze tweedeling zich uit in de vorm van een tak die Turgut Özal en zijn Moederlandpartij steunde en een andere tak die de uit de politiek verbannen Demirel steunde. De politiek was echter niet de enige factor die de Nurcu-beweging verdeelde. Momenteel bestaan er meer dan tien verschillende Nurcu-bewegingen, die in hun ideeën variëren van zeer fundamentalistisch tot modernistisch (Yavuz 2003: 179). 


\subsubsection{DE SÜLEYMANCIS}

De oprichter van de tweede grote islamitische 'neo-beweging' in Turkije, Süleyman Hilmi Tunahan (1888-1959), was zowel een Nakşibendi-sjeik als een conservatieve godsdienstgeleerde. Tunahan spande zich al in de jaren dertig en veertig in om, in deze periode waarin de republiek een einde had gemaakt aan al het formele religieuze onderwijs, toch islamitische vorming aan te bieden. Dit gebeurde uiteraard illegaal en Tunahan kwam dan ook zeer regelmatig in aanraking met de politie.

Het gebied waarop Tunahan en zijn volgelingen zich geconcentreerd hebben, is vooral dat van de koranscholen. Vanaf 1949 liet het kemalistische bewind, in het kader van de democratisering, koranscholen weer officieel toe en dit was een gelegenheid waarvan de Süleymancis dankbaar gebruikmaakten. Met hun 25 jaar ervaring waren zij uitstekend in staat religieuze functionarissen te trainen die een plaats konden vinden in de bureaucratie van het Presidium voor Religieuze Zaken. Toen in de jaren vijftig en zestig, met de groeiende welvaart op het platteland, het aantal moskeeën explosief begon te groeien, waren veel van de nieuw aangestelde predikers dan ook afgestudeerden van Tunahans opleidingen. Er ontstond een symbiotische relatie tussen de Süleymancıs en de staat. De Süleymancıs pasten zich aan door in hun islamitische onderwijs nationalisme en eerbied voor de staat een belangrijke plaats te geven en de staat zag in hen een mogelijk tegenwicht tegen het immer dreigende gevaar van het communisme.

De 'intieme' relatie tussen de Süleymancıs en de staat werd vanaf 1965 verstoord. Een nieuwe wet op het Presidium voor Religieuze Zaken bepaalde dat alleen afgestudeerden van de officiële scholen voor predikers en voorgangers nog aangesteld mochten worden. Na de militaire 'coup per memorandum' van maart 1971, waarbij het leger een aantal ingrijpende wetswijzigingen afdwong, werd een groot aantal particuliere scholen van de Süleymancıs door de staat overgenomen. De verkoeling van de betrekkingen met de staat leidde er ook toe dat de Süleymancıs een nieuw werkterrein zochten en dit vonden in de verzorging van islamitisch onderwijs voor de inmiddels heel grote Turkse gemeenschappen in Europa. Het Presidium voor Religieuze Zaken had de geestelijke verzorging van de Turkse migranten in Europa verwaarloosd en de activiteiten van de Süleymancıs beantwoordden dus aan een reële behoefte.

Na de militaire machtsovername van september 1980 kreeg het presidium de opdracht om de staatsgezinde islam in de vorm van de Turks-Islamitische Synthese onder de Turken in Europa te propageren. Dit leidde tot een herstel van de warme betrekkingen tussen het presidium en de Süleymancıs en gaf laatstgenoemden nog meer ruimte voor hun activiteiten. Momenteel beheerst de beweging met name in Duitsland een groot netwerk van internaten, waar met de modernste technologie onderwijs wordt gegeven en leerlingen worden geïndoctrineerd (Yavuz 2003: 146-7). Discipline neemt daarbij een centrale plaats in. Geheel in de eerdergenoemde Khalidi-traditie benadrukte Süleyman Tunahan de 
directe geestelijke band tussen de leermeester (hijzelf) en zijn volgelingen. De persoonsverheerlijking van Tunahan speelt binnen de beweging dan ook nog steeds een belangrijke rol. Hij geldt als de laatste en meest perfecte der heiligen. Opgaan in visoenen over de sjeik wordt gezien als een voorwaarde voor het leren kennen van de goddelijke werkelijkheid (Yavuz 2003: 145-7).

\subsubsection{DE FETHULLAHCILAR}

Een beweging die de grote nadruk op onderwijs van de Süleymancıs deelt, is die van de volgelingen van Hoca (leraar) Fethullah Gülen, in 1941 geboren in een dorp nabij Erzurum, in het noordoosten van Turkije. Deze beweging vormt een van de takken van de Nurcu-beweging, maar heeft vooral de laatste tien jaar een geheel eigen karakter gekregen.

Fethullah Gülen, in eerste instantie een volgeling van de Nurcu-beweging, begon zijn carrière als prediker in een moskee in Izmir, maar vond zijn roeping in het organiseren van onderkomens, een soort pensions, voor arme, islamitisch georienteerde leerlingen en studenten. Vandaaruit bouwde hij een onderwijsnetwerk op van zomerkampen en scholen waar leerlingen konden worden klaargestoomd voor de staatsexamens. Hiermee bood hij, net zoals Tunahan dat deed, een goedkoop alternatief voor de dure privé-opleidingsinstituten waarmee de stedelijke middenklasse haar kinderen een goede start in het leven gaf. In de loop der jaren kregen talloze leerlingen van arme komaf zo de kans om een loopbaan te beginnen in de enorme Turkse overheidsbureaucratie. Precies het soort infiltratie waar het Turkse leger en de secularistische middenklasse zo buitengewoon bezorgd over waren en zijn (Shankland 1999: 83-5).

Anders dan de Süleymancıs hebben Fethullah en zijn volgelingen ook een groot netwerk opgebouwd van instellingen voor voortgezet en hoger onderwijs. De liberalisatie van het Turkse onderwijs, vanaf 1983, maakte de oprichting van lycea en universiteiten mogelijk die niet door de staat maar door stichtingen werden beheerd. De beweging van Fethullah sprong hier actief op in en beheert nu, twintig jaar later, meer dan tweehonderd scholen voor voortgezet onderwijs en zeven universiteiten. Deze staan niet alleen in Turkije, maar ook in West-Europa (de Islamitische Universiteit in Rotterdam), op de Balkan en in Centraal-Azië.

Net als andere takken van de Nurcu-beweging hechtte Fethullah Gülen veel belang aan het ontwikkelen van eigen media. In eerste instantie ging het daarbij om gedrukte media, zoals het dagblad Zaman (De Tijd), maar door de liberalisatie van de Turkse radio en televisie kreeg hij ook de gelegenheid eigen radio- en televisiestations in gebruik te nemen. De bekendste hiervan is het televisiekanaal Samanyolu (Melkweg).

Gülens opkomst is zeker bevorderd door het feit dat hij zich vanaf het begin af aan resoluut achter de militaire staatsgreep van september 1980 stelde. Met behulp van de toenmalige premier, en latere president, Turgut Özal, die zelf 
sterke banden had met de Nakşibendi-orde, positioneerde Gülen zich als de woordvoerder van een moderne, vooruitstrevende en staatsgezinde islam. De symbiose van de Fethullahcular en de staat bleef lange tijd intact. Midden jaren negentig werd Fethullah Gülen binnen het politieke establishment nog algemeen gezien als het 'acceptabele gezicht van de islam' en politici van rechts (Tansu Çiller) tot links (Bülent Ecevit) prezen hem en ontmoetten hem publiekelijk. Gülen steunde dan ook het optreden van de legerleiding van februari 1997, ook toen dat uiteindelijk tot de val van de regering-Erbakan leidde. Hij bekritiseerde de Welvaartspartij van Erbakan, die hij als radicaal omschreef.

Ondanks al deze pogingen om zijn beweging als een steunpilaar van de staat af te schilderen, werd uiteindelijk ook de beweging van Fethullah door de militairen aangepakt - een actie die precies past in de draai die de secularistische, staatsgezinde groeperingen vanaf midden jaren negentig in Turkije hebben gemaakt en waarbij de hele erfenis van de coup van 1980, met zijn incorporatie van islam in de staatsideologie, ter discussie is gesteld. In juni 1999 begonnen de Turkse media, daarbij geregisseerd door de Nationale Veiligheidsraad, een felle campagne tegen Gülen op grond van de 'ontdekking' van tapes, waarop hij in preken uit 1986 zijn volgelingen opriep om geduld uit te oefenen en van onderaf de staatsorganen te penetreren. De chef van de Generale Staf sprak openlijk over Gülens plannen om de staat te ondermijnen en in 2000 werd een zaak tegen hem aanhangig gemaakt op grond van de beschuldiging dat hij het seculiere karakter van de republiek probeerde te veranderen. Fethullah Gülen zocht daarop zijn toevlucht in de Verenigde Staten, waar hij tot op de dag van vandaag verblijft (Yavuz 2003: 183, 202-3; Shankland 1999: 83-5).

\subsubsection{FINANCIERING VAN ORDES: STICHTINGEN EN VERENIGINGEN}

Bijna tachtig jaar na het oorspronkelijke verbod op de derwisjordes in Turkije zijn deze officieel voor de wet nog steeds verboden. Sinds de jaren vijftig, maar vooral vanaf de jaren tachtig hebben deze religieuze groeperingen, zowel degene die echt als orde gekwalificeerd kunnen worden als de neo-bewegingen, echter een immens netwerk kunnen opbouwen van scholen, uitgeverijen, tv-stations, ziekenhuizen en allerlei andere dienstverlenende instellingen. Deze instellingen hebben vrijwel altijd de juridische vorm van een stichting voor een goed doel (vakıf) en zij worden onderhouden door vrijwillige bijdragen. De steun voor de stichtingen is vaak georganiseerd in de vorm van verenigingen (dernek). Sinds de late jaren tachtig komen veel van de financiële bijdragen voor deze netwerken uit de hoek van islamitische zakenmensen. De liberalisatie van de Turkse economie heeft een hele nieuwe klasse van, vaak zeer welvarende, ondernemers in de Anatolische provinciesteden op de been gebracht. Dit zijn mensen die veelal strenge religieuze opvattingen combineren met modern ondernemerschap en een voorliefde voor technologie. Het meest bekende voorbeeld hiervan is het industriële conglomeraat Kombasan uit Konya, dat er recentelijk van is beschuldigd fundamentalistische bewegingen in Turkije te steunen met investeringen die onder valse voorwendselen geworven zouden zijn bij Turken in Europa. 
Deze combinatie van geld, een hechte organisatie en gerichte indoctrinatie via het onderwijs wordt door seculiere kringen in Turkije als de grootste bedreiging voor de westerse oriëntatie van het land gezien.

\subsection{SOENNITISCHE ISLAM EN ALEVITISME}

\subsubsection{DE NIET-SOENNITISCHE STROMINGEN}

In voorgaande paragrafen is weliswaar ingegaan op de veelvormigheid van de islam in Turkije, zoals die bijvoorbeeld tot uitdrukking komt in de verhouding tussen de staatsislam en de mystieke broederschappen en neo-bewegingen, maar daarbij ging het steeds over de soennitische islam. De indruk mag echter niet postvatten dat Turkije een uniform soennitisch land is. Integendeel, het land herbergt naast een meerderheid van 8 o tot 85 procent soennieten, ook belangrijke heterodoxe groeperingen. Daarmee reflecteert Turkije de verhoudingen binnen de islamitische wereld als geheel.

De grote meerderheid van de moslims in de wereld, zo'n 85 procent, hangt de soennitische richting van het geloof aan. Er bestaan echter nog een paar dozijn andere richtingen en stromingen binnen de islam. De bekendste daarvan is die van de sjia, meer in het bijzonder de stroming van de zogeheten 'twaalver' sjiieten, een naam die verwijst naar het feit dat de aanhangers twaalf rechtmatige opvolgers van de profeet Mohammed erkennen. Deze geloofsrichting is de staatsgodsdienst van Iran en de religie van de meerderheid van de Iraakse bevolking.

Van de kleinere stromingen binnen de islam behoort er een aantal tot de sjia, maar niet tot de Iraanse variant. Een aantal andere heeft wel duidelijke overeenkomsten met de sjiitische richting, maar de aanhangers worden door de meeste sjiieten zelf niet als geloofsgenoten beschouwd. Hiertoe behoren bijvoorbeeld de druzen van Syrië en Libanon, de alawieten van Syrië, de ehl-i haqq en yezidis ('duivelaanbidders') van Koerdistan en de alevieten van Turkije. De opvattingen van dit soort groepen wijken dermate af van die van de soennitische en sjiitische hoofdstromen dat voor hen in het Midden-Oosten de verzamelnaam ghulât ('overdrijvers') in gebruik is geraakt (Douwes in Driessen (ed.) 1997: 162).

In dit hoofdstuk willen wij ons met name concentreren op een van deze heterodoxe stromingen: die van de alevieten van Turkije.

\subsubsection{WIE ZIJN DE ALEVIETEN?}

De alevieten vormen momenteel de grootste religieuze minderheid van Turkije. Het is echter haast onmogelijk te zeggen om hoeveel mensen het gaat. De Republiek Turkije erkent geen etnische of religieuze minderheden anders dan de christelijke en joodse, waarvan de status in het Vredesverdrag van Lausanne (1923) internationaal is vastgelegd. De meeste alevieten spreken Turks, een klei- 
ner deel spreekt een van de Koerdische talen. Zij leven verspreid over grote delen van het land en hebben geen bijzondere uiterlijke kenmerken. De Turkse volkstellingen registreren de alevitische religie niet. De alevieten worden eenvoudigweg als moslim geregistreerd. Schattingen over het aantal alevieten lopen dan ook sterk uiteen, van tien tot twintig miljoen. Een schatting van twaalf tot vijftien miljoen is misschien het meest realistisch (Shindeldecker 2000; Kehl-Bodrogi 1997: XI-XII; Gezik 200o; Shankland 1999: 136).

Het traditionele concentratiegebied van de Turkse alevieten is een brede gordel die zich uitstrekt vanaf Ankara via Çorum, Yozgat, Amasya, Samsun, Tokat en Sivas, tot Erzincan in het oosten en Kahramanmaraş in het zuiden. Koerdische alevieten wonen vooral in de provincies Bingöl, Elazığ, Tunceli en Malatya. Voor de alevieten geldt echter wat voor de plattelandsbevolking van Turkije als geheel geldt: door de enorme trek naar de stad die sinds de jaren vijftig is opgetreden, woont een groot deel van de bevolking nu in de immense agglomeraties van Istanbul, Izmir, Ankara, Bursa en Adana. Omdat de gebieden waar de alevieten vandaan komen tot de armere regio's van Turkije behoren, is de migratie daar relatief sterk geweest. Het is dan ook niet overdreven om te verwachten dat ongeveer de helft van de alevitische bevolking tegenwoordig in de grote steden woont. De trek naar de stad heeft voor de alevitische identiteit, zoals we zullen zien, grote gevolgen gehad.

Historisch gezien is het moderne alevitisme voortgekomen uit de vele heterodoxe groepen die in het begin van de zestiende eeuw onder invloed kwamen van de missie van de sjiitische Safawidenbeweging en die de Safawidische sjah Ismaïl steunden tegen de Osmaanse sultan. De in essentie politieke machtsstrijd tussen de soennitische Osmanen en de sjiitische Safawiden dwong de bevolking van Anatolië en Koerdistan partij te kiezen. Voor veel Anatolische stammen, die een heterodoxe, syncretistische vorm van de islam aanhingen waarin ook christelijke en sjamanistische elementen een rol speelden, was de Safawidenbeweging veel herkenbaarder dan de inmiddels sedentair en soennitisch geworden Osmanen.

De Osmanen slaagden erin de Safawidische beweging in Anatolië en het westen van de Koerdische gebieden militair uit te schakelen. Hierbij organiseerde met name de Osmaanse sultan Selim I (r. 1512-1520) verschrikkelijke pogroms onder de Anatolische ghulât. Deze conflicten en vervolgingen hebben de verhouding tussen de Osmaanse staat en de alevitische minderheid in de volgende eeuwen bepaald. De alevieten konden zich in afgelegen delen van het platteland handhaven en vermeden waar mogelijk het contact met de staat en met de soennitische bevolking. In zichzelf gekeerd, ontwikkelde de alevitische gemeenschap een hechte sociaal-religieuze organisatie die hen in staat stelde in een vijandige omgeving te overleven (Ocak 1997). Tegenover de buitenwereld hanteerden de alevieten het, ook in andere takken van de sjia geaccepteerde, principe van de takiye (voorzichtigheidshalve verzwijgen van de eigen overtuiging). $\mathrm{Na}$ de zestiende eeuw is de Osmaanse politiek niet meer gericht geweest op vervolging van de alevitische 'ketters' en spreidde de staat een soort stilzwij- 
gende tolerantie ten toon. Stilzwijgend, want verdeeldheid binnen de gemeenschap der gelovigen was ideologisch niet aanvaardbaar en werd ook nergens vermeld. Theoretisch was de ümmet, de islamitische geloofsgemeenschap, immers één en ondeelbaar. Deze tolerantie betekende ook geen gelijkberechtiging. Onder de soennitische meerderheid werden alevieten over het algemeen veracht en leefden er allerlei vooroordelen over de relatief gesloten en onbekende alevitische gemeenschap, die met name betrekking hadden op hun seksuele moraal. Tot op de dag van vandaag zijn sporen van deze vooroordelen aanwezig.

Het alevitisme bleef in stand doordat, in zekere zin vergelijkbaar met het joodse volk, de religie tegelijk als een etniciteit werd beschouwd. De alevieten beschouwden zichzelf als een tribale gemeenschap en handhaafden een strikte endogamie. Alleen wie binnen de gemeenschap geboren was, kon kennis over de alevitische leer ontvangen. De leer werd mondeling overgedragen door de dedes ('grootvaders') of pirs ('ouden'), die een soort erfelijke priesterkaste vormden en afstamming van de profeet claimden. De dedes traden binnen de gemeenschap ook op als rechters en bemiddelaars, waarmee zoveel mogelijk voorkomen werd dat de leden van de gemeenschap een beroep op de Osmaanse rechter zouden moeten doen (Kehl-Bodrogi 1997: XI-XII).

\subsubsection{ZIJN DE ALEVIETEN MOSLIMS?}

De veelgestelde vraag of de alevieten, die in hun geloofsovertuiging en -praktijk zo ver afwijken van de soennitische orthodoxie, nog als moslims beschouwd kunnen worden, is er een die zowel binnen de soennitische als binnen de alevitische gemeenschap heel verschillend wordt beantwoord. De meest zinvolle manier om tot een antwoord te komen, zonder daarbij een waardeoordeel uit te spreken (de sekte van de een is immers de godsdienst van de ander), lijkt het naast elkaar leggen van enerzijds de alevitische opvattingen en anderzijds de basiskenmerken van de soennitische en 'twaalver' sjiitische islam.

In deze beide takken van islam worden de zogenaamde 'vijf zuilen' als de basisplichten van het geloof gezien:

1 de geloofsbelijdenis;

2 de vasten;

3 het rituele gebed;

4 gaven aan de armen;

5 de pelgrimstocht naar Mekka.

Aan de hand van deze 'checklist' kunnen we de volgende verschillen constateren.

1 De geloofsbelijdenis

Iedereen die moslim wil worden, dient de geloofsbelijdenis uit te spreken: "Er is geen god dan Allah/God en Mohammed is Gods gezant." Alevieten spreken de geloofsbelijdenis ook uit, maar in hoeverre dit een vorm van takiye is, is onzeker. 
Sommige alevieten voegen eraan toe: "En Ali is de stadhouder van God en de vertrouweling van Mohammed." Dit drukt het enorme belang uit dat de alevieten, net als andere sjiieten, aan de persoon van Ali, de schoonzoon en neef van de profeet, hechten. Zij zien hem als de eerste moslim, de enige rechtmatige opvolger van Mohammed die echter door 'bedriegers' opzij werd geschoven na de dood van de profeet. Sommigen gaan zelfs zo ver dat zij ervan overtuigd zijn dat Gods openbaring in feite niet voor Mohammed, maar voor Ali was bedoeld. In de praktijk van het geloof vervult Ali een grotere en vooral een emotionelere rol dan Mohammed.

In het alevitische denken speelt daarnaast het concept van de goede of complete mens (insan), van wie Ali het prototype is, een grote rol. Men relativeert daarmee ook het geloof zelf, zeggend dat niet het geloof, maar het zijn van een (goed) mens belangrijk is. Moderne alevitische schrijvers trekken daarom vaak vergelijkingen met het Europese humanisme.

2 De vasten

Zowel soennitische als 'reguliere' sjitische moslims vasten tussen zonsopgang en zonsondergang gedurende de dertig dagen van de maand Ramazan van de islamitische kalender. Alevieten doen dit meestal niet. Wel wordt door velen gevast gedurende twaalf dagen van de maand Muharrem. Met deze vasten wordt gerouwd om de dood van Ali's jongste zoon die, samen met vrijwel de hele familie van Ali, in $680 \mathrm{n}$. Chr. door tegenstanders werd omgebracht.

3 Het rituele gebed

Terwijl vrome moslims vijfmaal per dag het rituele gebed (namaz) verrichten, een combinatie van strikt gereguleerde bewegingen en uitspraken, en voor alle mannelijke moslims het vrijdagmiddaggebed met het beluisteren van de wekelijkse preek in principe verplicht is, doen de alevieten geen van beide. In alevitische dorpen waren dan ook van oudsher geen moskeeën te vinden, al zijn zowel in het late Osmaanse rijk als in de republiek pogingen gedaan om de alevieten te 'soennificeren' door moskeeën in hun dorpen en wijken neer te zetten. In de republiek is dat met name na 1980 gebeurd, toen de Turks-Islamitische Synthese, met zijn gemengd religieus-nationalistische boodschap de staatsideologie werd.

Alevieten hebben wel hun eigen religieuze bijeenkomsten, of zo men wil diensten. Dit is de ayini cem (bijeenkomst), die traditioneel op donderdagavond plaatsvindt. De ayini cem, die in een speciaal daarvoor bestemde ruimte gehouden kan worden, maar ook in een gewoon huis, wordt geleid door een dede, die bij deze gelegenheid ook geschillen hoort, mensen verzoent en straffen kan opleggen. De meest ingrijpende sanctie daarbij is een vorm van excommunicatie (düşkünlük), een buiten de gemeenschap plaatsen, wat natuurlijk vroeger in een geïsoleerd Anatolisch dorp vrijwel gelijkstond aan een doodvonnis. Het opbiechten van zonden en een gezamenlijke maaltijd, die wellicht sporen zijn van overgenomen christelijke sacramenten, maken deel uit van de dienst, waaraan mannen en vrouwen gezamenlijk deelnemen. Muziek in de vorm van balla- 
des die begeleid worden met een luit, onder andere over de dood van Ali en zijn zoons, heeft een heel belangrijke plaats in het alevitische ritueel.

\section{Gaven aan de armen}

Er is onder alevieten een sterke traditie van het geven voor goede doelen ten bate van de gemeenschap, maar dit gebeurt niet volgens de gedetailleerde regels die in de soennitische islam zijn uitgewerkt.

\section{De pelgrimstocht naar Mekka}

Het is geen alevitische gewoonte om op pelgrimstocht naar Mekka te gaan, maar men bezoekt graag de graftombes van alevitische heiligen in Anatolië. Het doel daarvan is een spirituele reiniging, niet het verkrijgen van een plaats in het paradijs. De bekendste pelgrimage vindt plaats op 16 augustus en voert naar het graf van Haci Bektaş, de stichter van de met het alevitisme verwante Bektaşi-derwisjorde, die voor 1925 wijdverbreid was en die momenteel vooral nog voortleeft in Albanië. De exacte relatie tussen de meer stedelijke en geletterde leden van de Bektaşi-orde en de orale tradities van de alevieten is al lang onderwerp van wetenschappelijk debat.

Uit het bovenstaande kan men wellicht concluderen dat alevieten weliswaar heel ver van de 'mainstream' van de islam af staan, maar dat zij nog wel tot de (sjiitische) islam behoren, iets wat bij andere 'ghulât-gemeenschappen', zoals de druzen en de yezidis, veel minder duidelijk is. Als we weer een vergelijking met het christendom trekken, zouden we misschien kunnen zeggen dat soennieten en alevieten moslims zijn, zoals rooms-katholieken en quakers beiden christenen zijn.

\subsubsection{ALEVIETEN EN HET KEMALISME}

Verschillende moderne alevitische auteurs claimen voor hun gemeenschap een centrale rol in de start van de onafhankelijkheidsbeweging (Şener 1991: 12), maar dit is sterk overdreven. Wel lijken de meeste alevieten zich gedurende de Turkse onafhankelijkheidsoorlog (1919-1922) aan de kant van Mustafa Kemal Pasja en zijn nationale beweging in Anatolië geschaard te hebben. Hoewel die beweging nadrukkelijk strijd voerde uit naam van de sultan-kalief (Zürcher in Karpat (ed.) 2000: 150-79), zocht Mustafa Kemal hun steun nadrukkelijk. Niettemin waren er ook voorbeelden van, vooral Koerdische, alevitische stammen die zich tegen het gezag van Ankara verzetten. Dit verzet werd vooral ingegeven door een afkeer van de pogingen van de centrale staat om effectieve controle te vestigen over de tot dan toe in feite autonome stammen in de berggebieden van Oost-Anatolië.

De herinnering aan de onderdrukking van de alevieten door de Osmaanse staat en hun positie als gewantrouwde marginale groep binnen het soennitische kalifaat (dat honderden jaren werd uitgeoefend door de Osmaanse sultans) maakte hen tot natuurlijke bondgenoten van de kemalistische hervormers. Deze hervormers ontnamen immers de soennitische islam zijn dominante rol in het open- 
bare leven (Aydin 20oo: 16-26). Hoewel staat en maatschappij ook onder de republiek gedomineerd bleven door soennitische moslims, ontdeed het vergaande secularisme en antiklerikalisme van de kemalistische republiek de staat voor een deel van zijn, in alevitische ogen vijandige karakter. Zij waren bereid te accepteren dat ook de republiek hen niet als religieuze gemeenschap erkende, zolang diezelfde republiek alle vormen van religie een plek in de publieke sfeer ontzegde. Takiye bleef ook in de republiek een 'way of life' voor de alevieten, maar zij kregen meer kansen op sociale mobiliteit (Kehl-Bodrogi 1997: XII-XIII).

De liefde tussen de staat en de alevieten kwam tot op zekere hoogte van twee kanten. De met het alevitische geloof verwante Bektaşi-orde werd, tot teleurstelling van de Bektaşi's zelf, niet uitgezonderd van het verbod op de derwisjordes, maar de erfenis van de Bektaşi's werd positief beoordeeld. Het ministerie van Onderwijs gaf zelfs een anthologie van Bektaşi-dichters uit, van wie de gedichten werden aangeprezen als voorbeelden van de 'echte' Turkse cultuur (Birge 1937: 17). In het proces van natievorming op basis van een Turkse nationale identiteit werden de alevieten ook gepositioneerd als degenen die in de Osmaanse eeuwen, toen de elitecultuur volledig werd gedomineerd door de Arabische en Perzische talen en culturen, vasthielden aan het Turks en daarmee de Turkse cultuur voor de ondergang behoedden (Shankland 1993: 175; Poulton 1997: 126). Met name de gelijkberechtiging van de vrouwen in de alevitische en Bektaşicultuur werd geïnterpreteerd als het voortleven van oude Turkse tradities, waar de moderne republiek nu weer bij aansloot (Poulton 1997: 126-7).

Tegelijkertijd werden sommige van de heftigste gewapende conflicten van de jaren dertig uitgevochten tussen de troepen van de kemalistische republiek en alevitische groepen. Toen de staat in de jaren dertig effectieve controle wilde vestigen in het uitgestrekte en uitermate geïsoleerde berggebied van Dersim, brak daar een opstand van de alevitische Koerdische stammen uit, die met zeer harde hand werd onderdrukt. In de nasleep van de opstand werden grote aantallen inwoners van Dersim op transport gesteld en naar West- en Midden-Anatolië gedeporteerd, waar hun nakomelingen nog steeds leven.

\subsubsection{DE TREK NAAR DE STAD}

Eeuwenlang vormden de alevieten in essentie een plattelandsgemeenschap die in een ruimtelijk en sociaal isolement had kunnen voortbestaan door contact met de buitenwereld zoveel mogelijk te vermijden. In zo'n omgeving kon de orale traditie, gesteund door het gezag van de dedes, de gemeenschap structuur en houvast geven. Maar vanaf het midden van de jaren vijftig begon in Turkije door de mechanisatie van de landbouw, die veel mankracht overbodig maakte, en de industrialisatie in sommige stedelijke centra, de trek van het platteland naar de stad. Woonde in 1950 nog tachtig procent van de bevolking op het platteland, ruim vijftig jaar later is dat percentage gehalveerd. In de urbane, geïndustrialiseerde omgeving met haar anonimiteit kon het alevitische geloof, dat gebaseerd 
was op persoonlijke contacten, zich moeilijk in traditionele vorm handhaven (Kehl-Bodrogi 1997: 119-20).

In de nieuwe, onpersoonlijke omgeving van de grote stad, waar zij bovendien dagelijks geconfronteerd werden met de soennitische meerderheid, zochten de alevitische nieuwkomers een nieuwe basis om solidariteitsnetwerken op te kunnen bouwen. Net als gold voor andere migrantengroepen in Turkije, vond de eerste generatie migranten die vooral in de hemşerilik, de gedeelde topografische afkomst. De typische migrantenorganisatie kon bijvoorbeeld de 'Vereniging van Mensen uit Sivas' zijn, met een eigen theehuis in de wijk waar veel migranten uit Sivas woonden als centrum en met een gekozen bestuur, dat de politieke steun van de gemeenschap effectief in kon zetten in de meerpartijendemocratie van na de oorlog om concessies van de stadsbestuurders te verkrijgen.

In de late jaren zestig leek het alevitisme als religieuze identiteit als sneeuw voor de zon te verdwijnen. In plaats daarvan interpreteerden steeds meer, vooral jongere alevieten hun erfenis nu in politieke termen. De meeste alevieten waren traditioneel aanhangers van de door Atatürk opgerichte Republikeinse Volkspartij, dit vanwege de nadruk op secularisme in de ideologie en het programma van die partij. In de jaren zestig en zeventig kozen echter grote aantallen alevieten voor radicale vormen van socialisme, waarbij velen uiteindelijk in de buitenparlementaire oppositie en soms zelfs in de stadsguerrilla terechtkwamen. In alle extreem-linkse strijdgroepen van die tijd waren de alevieten sterk oververtegenwoordigd. In de opvattingen over een collectieve identiteit van deze groep werd alevitisme synoniem aan communisme. De geschiedenis van het alevitisme werd opnieuw geïnterpreteerd als een verhaal van de strijd voor rechtvaardigheid en tegen onderdrukking, met hoofdrollen voor Ali, Huseyn en de alevitische heiligen. Sommigen zagen alevitisme uitdrukkelijk als een vorm van proto-communisme (Van Bruinessen 1996: 8).

De herdefinitie van het alevitisme als een politieke ideologie, in plaats van een etno-religieuze identiteit, zorgde er ook voor dat in de jaren zestig de pogingen om van een eigen alevitische partij de spreekbuis van de religieuze gemeenschap te maken, mislukten. De pogingen waren er wel. In 1966 richtte een groep alevitische ondernemers de Birlik Partisi, de Partij van de Eenheid op. Deze partij adverteerde zichzelf zeer nadrukkelijk als alevitisch, maar kwam desondanks bij opvolgende verkiezingen niet verder dan enkele procenten van de stemmen. De aantrekkingskracht van de linkse politiek was voor de geseculariseerde alevieten veel groter (Yavuz 2003: 67; Kehl-Bodrogi 1997: XIII).

De rol van de alevieten in de extreem-linkse bewegingen zorgde ervoor dat ook bij de tegenstanders, met name door de soennitische ultranationalisten van de Nationalistische Actie Partij - de zogenaamde 'Idealisten' ('Ülkücüler') of ‘Grijze Wolven' - de identificatie: 'Alevitisme is communisme' werd overgenomen. Dit gaf deze groepen de gelegenheid om bij de mobilisatie van hun aanhang gebruik te maken van alle bestaande vooroordelen over de alevieten. In de tweede helft 
van de jaren zeventig, een periode van grote maatschappelijke en politieke spanningen in Turkije, leidde dit tot pogroms tegen alevieten in een reeks van Anatolische stedelijke centra, zoals Tokat, Çankırı, Çorum, Sivas en Kahramanmaraş. Vooral de botsingen in Kahramanmaraş van december 1978 waren zeer gewelddadig en leidden tot 106 doden, grotendeels alevieten, en de afkondiging van de staat van beleg in elf provincies. In juli 1980 vielen soennitische extremisten in Çorum opnieuw doelen in alevitische buurten aan en doodden 26 mensen (Yavuz 2003: 68; Poulton 1997: 162).

\subsubsection{DE HERONTDEKKING VAN HET RELIGIEUZE ALEVITISME}

De militaire machtsovername van september 1980 makte niet alleen effectief een einde aan het politieke geweld op straat, maar onderdrukte ook de extreemlinkse en socialistische bewegingen waarin de alevieten zo'n prominente rol speelden.

In de jaren tachtig en negentig leidden twee factoren tot een grondige heroriëntatie van de alevitische gemeenschap. Ten eerste was dat de instrumentalisering van de soennitische islam in dienst van de staatsideologie. De introductie van de Turks-Islamitische Synthese als semi-officiële staatsideologie en het gebruik van een staatsgezinde, 'Turkse' islam als bindmiddel, eerst door de militaire junta en later door premier/president Turgut Özal, vervreemdden de alevieten van de staat. Zij kregen het gevoel niet langer op het seculiere karakter van de republiek te kunnen vertrouwen. Met de terugkeer in de politiek van de 'oude' politici in oktober 1987, onder wie de islamist Erbakan en de ultranationalist Türkeş, werd dit gevoel versterkt. De grote verkiezingsoverwinningen van Erbakans Welvaartspartij in 1994-1995 en van de Nationalistische Actie Partij in 1999 leken de ergste vermoedens te bevestigen en de alevieten behoorden dan ook tot de groepen in Turkije die in de jaren negentig het scherpst reageerden tegen de islamisering.

In juli 1993 kwamen de oplopende spanningen tot een uitbarsting. Tijdens een alevitisch festival in Sivas, een etnisch en religieus zeer gemengde regio, viel een woedende menigte soennieten een hotel aan waar alevitische dichters en zangers verbleven. Het hotel werd in brand gestoken, waarbij 36 alevitische intellectuelen en een Nederlandse studente omkwamen. Aanleiding voor het geweld was een toespraak van de schrijver Aziz Nesin (die tevens de vertaler is van Salman Rushdies Duivelsverzen), waarin hij verklaarde dat hij persoonlijk niet in de koran geloofde. Het wantrouwen van de alevieten jegens de staat werd met name aangewakkerd doordat op filmbeelden zichtbaar was dat de burgermeester van Sivas aan de demonstratie deelnam en dat de politie nauwelijks ingreep, maar daarnaast ook doordat de daders weliswaar door het Staatsveiligheidshof in Ankara werden veroordeeld, maar daarbij wel strafvermindering kregen omdat zij 'geprovoceerd waren' (Poulton 1997: 262-3). Na de brand in Sivas volgden nog verschillende andere acties die gericht waren tegen alevieten. In 1994 liet de gemeente Istanbul, toen beheerst door de Welvaartspartij, een alevitisch heilig- 
dom slopen en in maart 1995 openden soennitische radicalen het vuur op een aantal koffiehuizen in de alevitische wijk Gazi in Istanbul. Dit leidde tot massale protesten in het hele land, waarbij zo'n dertig mensen omkwamen. De rust keerde pas terug toen in Gazi de - sterk door 'Grijze Wolven' geïnfiltreerde politie was vervangen door legereenheden.

De tweede ontwikkeling die rond 1990 de alevieten ertoe bracht hun identiteit weer meer etno-religieus te definiëren in plaats van politiek, was de ondergang van de Sovjet-Unie en de crisis die dat voor linkse bewegingen met zich meebracht. Hoewel de radicale bewegingen in Turkije over het algemeen niet Moskou-getrouw waren en hun inspiratie meer zochten in het maoïsme of in de (stads)guerrillabewegingen van Latijns-Amerika, was de klaarblijkelijke triomf van het kapitalisme en de Amerikaanse overwinning in de Koude Oorlog toch een morele klap voor hen.

De reacties van de alevieten op de geschetste ontwikkelingen zijn verschillend geweest, maar de gemeenschappelijke factor in de reacties is een nieuw zelfbewustzijn en het zoeken van de publiciteit, waar die vroeger juist bijna ten koste van alles werd vermeden. $\mathrm{Al}$ in 1990 publiceerde een aantal leidende alevieten een manifest in een van de grote landelijke dagbladen, waarin erkenning van de gemeenschap en godsdienstvrijheid werd gevraagd. Steeds openlijker uitten de alevieten hun onvrede over het feit dat zij als belastingbetalers meebetalen aan de enorme bureaucratie van het Presidium voor Religieuze Zaken, maar dat deze organisatie zich uitsluitend bekommerde om het soennitische deel van de bevolking (Shindeldecker 2000).

Het gevolg van de alevitische 'coming out' is een stroom van publicaties geweest, grotendeels uit alevitische hoek. Het aantal alevitische verenigingen is tegelijkertijd spectaculair gegroeid. Hierdoor is het alevitisme in Turkije, en ook in Europa, veel zichtbaarder geworden. Wat echter ook zichtbaar is geworden, is de versplintering binnen de gemeenschap. Het wereldwijde fenomeen van het verlies aan aantrekkingskracht van diverse vormen van socialisme is hier ten dele debet aan. Op een dieper liggend niveau weerspiegelt deze versplintering ook de problemen die de alevieten hebben bij het vinden van een nieuw richtsnoer in de geïndustrialiseerde, geïndividualiseerde en anonieme grootstedelijke omgeving, waarin de meesten van hen nu leven en waarin oraliteit en directe contacten niet langer hun centrale rol in het bijeenhouden van de geloofsgemeenschap kunnen spelen.

In de hedendaagse herinterpretatie van het alevitisme bestaan verschillende opvattingen naast elkaar. Sommige groepen houden in deze omstandigheden vast aan de interpretatie van het alevitisme als een etno-religieuze gemeenschap, maar willen die moderniseren en zuiveren van 'bijgeloof'. Voor een deel van deze groep is alevitisme eigenlijk helemaal geen geloof, maar een seculier waardenstelsel. Een andere stroming zoekt juist toenadering tot de schriftuurlijke, orthodoxe islam, waarbij de meerderheid zich spiegelt aan de soennitische 
islam van Turkije, maar een minderheid de sjia van de islamitische republiek Iran als voorbeeld kiest. Deze toenadering tot orthodoxe varianten van de islam schept ook de behoefte aan een eigen alevitische theologie en sacrale teksten. Het lijkt voor de hand te liggen dat alevieten daarvoor een beroep doen op de voortbrengselen van de Bektaşi-derwisjorde. Vooralsnog zijn de pogingen om het alevitisme meer naar de soenna te modelleren echter zeer problematisch. Verder bestaan er ook groepen die zich juist inspannen om de authenticiteit en eigenheid van het syncretistische alevitische geloof te bewaren, maar het zijn juist deze groepen die het in de urbane omgeving extra lastig hebben (Çamuroğlu in Kehl-Bodrogi (ed.) 1997: 28-9).

De felle strijd tussen het Turkse leger en de Koerdische onafhankelijkheidsbeweging PKK in de jaren negentig plaatste de alevieten, in een omgeving waarin etnisch nationalisme steeds dominanter werd, bovendien voor een probleem bij het bepalen van hun positie. Dit was voor een gemeenschap die van oudsher bestond uit zowel Koerdisch- als Turkssprekende leden, uitermate lastig. Het gepropageerde nationalisme was echter zo sterk dat aanzienlijke groepen Koerdische en Turkse alevieten zich in de eerste plaats gingen identificeren met respectievelijk de Koerdische opstandelingen en de Turkse staat en daar ook de politieke consequenties uit trokken (Çamuroğlu in Kehl-Bodrogi (ed.) 1997: 32).

De toenadering tussen Turkse nationalisten en alevieten werd vergemakkelijkt toen de staat, oog in oog met de doorbraak van de politieke islam van midden jaren negentig, brak met de islampolitiek die sinds de staatsgreep van 1980 werd gepropageerd. Met de strijd tegen de politieke (soennitische) islam, die het leger sinds 1997 heeft ingezet, is in secularistische kringen ook een discours opgekomen waarin de alevitische islam als 'typisch Turkse islam' afgezet wordt tegen de Arabische. De implicatie is dat de Turkse islam traditioneel humanistische en emancipatoire waarden heeft omarmd, terwijl de Arabische islam staat voor verstarring, bekrompenheid en fundamentalisme (Yavuz 2003: 253). Het jaarlijkse grote festival bij het graf van Haci Bektaş wordt tegenwoordig door de staat erkend en de staatsbegroting bevat nu ook posten voor steun aan alevitische verenigingen en voor onderzoek naar het alevitisme.

\subsection{ISLAM, FUNDAMENTALISME EN TERRORISME}

\subsubsection{TERRORISTISCHE AANSLAGEN}

In november 2003 werd Istanbul opgeschrikt door vier zelfmoordaanslagen, waarbij in totaal 62 doden vielen. Eerst werden twee synagogen aangevallen en vijf dagen later het Britse consulaat-generaal en een Britse bank. In eerste instantie werd zowel door de Turkse politiek als door de publieke opinie volgehouden dat de daders Arabieren waren. Deze gedachte leek bevestigd te worden toen alQaeda in een e-mail de aanslagen opeiste. Onderzoek van de politie en de veiligheidsdiensten bracht echter al heel snel een andere waarheid aan het licht: de 
daders waren Turkse Koerden uit de provincie Bingöl en, hoewel ze vermoedelijk banden met al-Qaeda onderhielden, waren ze in de eerste plaats lid van eigen, in Turkije gevestigde organisaties.

Dit voorval maakte de media in binnen- en buitenland erop attent dat ook in Turkije illegale netwerken van moslimextremisten bestaan en dat dit verschijnsel niet voorbehouden is aan de Arabische landen, Pakistan of Indonesië. Islamitisch extremisme, of fundamentalisme is dus ook een deel van het landschap van de Turkse islam. Maar wat is islamitisch fundamentalisme nu eigenlijk precies en hoe onderscheidt het zich van andere stromingen binnen de islam?

\subsubsection{MODERNISME, FUNDAMENTALISME EN TRADITIONALISME}

Uiteindelijk is de islam een op tekst gebaseerde gemeenschap en net als andere dergelijke gemeenschappen, zoals christendom en jodendom, is de islam door de eeuwen heen geconfronteerd met het dilemma van, aan de ene kant, de absoluutheid van Gods wil zoals die volgens de islamitische geloofsvisie voor de laatste keer aan de profeet Mohammed is geopenbaard en, aan de andere kant, de noodzaak van voortdurende herinterpretatie. In de debatten hierover zijn zowel in de klassieke als in de hedendaagse periode drie ideaaltypische posities ingenomen, die kunnen worden aangeduid met modernisme, fundamentalisme en traditionalisme.

Modernisten, of vernieuwers, staan voor een voortdurende herinterpretatie van het morele ideaal. Modernisten worden vaak gemotiveerd door een behoefte om het morele ideaal aan te passen en relevant te maken in veranderende omstandigheden. Maar niet minder vaak worden zij gedreven door de behoefte van politieke machthebbers of oppositiegroeperingen om het morele ideaal naar hun hand te zetten. In dit streven benadrukken de modernisten de morele zelfstandigheid van de mens en zijn vrijheid en vermogen om door middel van zijn eigen mentale capaciteiten morele kennis te verwerven. Fundamentalisten verzetten zich juist tegen de interpretatie van het morele ideaal. Dit verzet is meestal gemotiveerd door de wens om het te behoeden voor manipulatie en corruptie door machthebbers of andere politici die proberen er hun politieke aspiraties mee te rechtvaardigen. In dit verband benadrukken de fundamentalisten vaak de ontoereikendheid en subjectiviteit van het morele oordeelsvermogen van de mens, dat volgens hen onvermijdelijk is en altijd het eigenbelang weerspiegelt.

De derde positie, die van het traditionalisme, staat de interpretatie van het morele ideaal toe, maar wanneer een bepaalde interpretatie eenmaal heeft plaatsgevonden en is bevestigd door de overeenstemming der gelovigen, kan deze nooit meer worden herzien. De gezaghebbende tekst van de islam breidt zich hierdoor steeds verder uit met de interpretaties van eerdere generaties. Het traditionalisme is een soort compromis tussen de extreme posities van modernisme en fundamentalisme. Door interpretatie in nieuwe gevallen toe te staan, biedt 
het enerzijds flexibiliteit terwijl het anderzijds houvast biedt door herinterpretatie te verbieden (Hoebink in Driessen (red.) 1997: 200-1).

In termen van het Turkse islamitische landschap laat voorgaande driedeling zich vrij eenvoudig vertalen. De Jong Turkse en kemalistische interpreten van de islam, die de 'ware' islam meenden te kunnen definiëren als een persoonlijke geloofsovertuiging gestoeld op de ratio, die openstond voor de wetenschap en die de bronnen van de islam via Turkse preken en Turkse koranvertalingen direct toegankelijk wilden maken voor de gewone gelovigen, kan men als islammodernisten zien. Dat geldt evenzeer voor de belangrijkste takken van de Nurcu-beweging, al zijn er binnen die wijdvertakte beweging ook groepen, zoals de Aczmendi-beweging, die sterk zijn opgeschoven in de richting van het fundamentalisme en die het maatschappelijk leven willen modelleren naar de gemeenschap van Mohammed.

De orthodoxe Nakşibendi-derwisjen en de daaruit voortgekomen Nationale Visie-beweging laten zich misschien het best als traditionalistisch classificeren. Voor de kleine ondernemers (esnaf) die de oorspronkelijke aanhang van Erbakans partij vormden, was dit juist de grote aantrekkingskracht. De Nationale Visie-beweging heeft sinds de jaren zeventig weliswaar veel politieke en sociale macht vergaard, maar uiteindelijk intellectueel heel weinig aan een vernieuwd elan van de islam bijgedragen. Ook deze richting is echter geen monoliet. In Nederland zien we bijvoorbeeld hoe de Amsterdamse tak van de Nationale Visie zich onder leiding van Haci Karacaer juist tot een spreekbuis heeft gemaakt van vooruitstrevende ideeën over de rol van de man in het gezin en over homoseksualiteit, waarmee deze tak ver verwijderd is geraakt van de 'mainstream' van Milli Görüş in Europa en Turkije.

In de enorme organisatie van het Presidium voor Religieuze Zaken vindt men zowel (gematigd) modernistische als traditionalistische stromingen. Echte fundamentalisten vinden we in Turkije vooral in een aantal relatief kleine maar hecht georganiseerde en actieve bewegingen. Het gaat hierbij om mensen die herinterpretatie en aanpassing van het morele ideaal afwijzen en de bronteksten van de islam: de koran en tradities over het leven van de profeet Mohammed, als absoluut geldig en de letterlijke waarheid zien. Dat laatste standpunt wordt weliswaar ook door veel 'gewone' moslims onderschreven, maar de fundamentalisten trekken hieruit de conclusie dat het leven in de islamitische maatschappij daadwerkelijk geheel naar de letter van de goddelijke openbaring ingericht dient te worden. Kenmerkend voor deze groeperingen is hun eis dat de islamitische heilige wet, de şeriat, de enige basis voor het politieke en juridische systeem in het land dient te zijn. Handhaving van de heilige wet dient volgens hen met alle middelen, desnoods ook met geweld, bevorderd te worden (Jansen 1998: 23-5).

Hiermee gaan zij natuurlijk rechtstreeks in tegen de politieke orde en het rechtsstelsel van de Turkse republiek. Daarnaast zal het uit eerdere passages duidelijk zijn dat zij hierdoor ook volledig breken met de Osmaanse traditie, die immers 
nooit een de facto centrale plaats aan de heilige wet had toegekend. Vanzelfsprekend is agitatie voor fundamentalistische denkbeelden in Turkije strikt verboden. Elke van de hieronder besproken bewegingen is dan ook illegaal.

\section{$2.4 \cdot 3$ IBDA-C}

İslami Büyük Doğu Akıncıları - Cephe (De Stoottroepen van het Islamitische Grote Oosten-Front) is een organisatie met wortels in het midden van de jaren zeventig. In die periode maakte een radicale fractie zich los van de jeugdorganisatie van Necmettin Erbakans Nationale Heilspartij, die in die periode een aantal keer regeringsverantwoordelijkheid droeg in coalitiekabinetten. In de ogen van deze radicalen was Erbakan zijn idealen ontrouw geworden door deel te nemen aan het 'corrupte' Turkse regime.

De leden van de IBDA ontlenen veel van hun gedachtegoed aan de geschriften van de Turkse schrijver en dichter Necip Fazıl Kısakürek (1905-1983). Necip Fazıl was een van de weinige islamistische denkers die gedurende de kemalistische republiek een duidelijk tegengeluid lieten horen tegen het ontwikkelingsmodel van Atatürk en de zijnen. Tegenover de omarming van de contemporaine westerse beschaving die de kemalisten voorstonden, stelde hij dat de islam niet alleen een religie was, maar een complete, aparte beschaving met eigen culturele codes en een eigen moraliteit, die een levensvatbaar alternatief voor de westerse beschaving kon vormen. In zijn ogen leidde de overname van de Europese beschaving tot schizofrenie in de Turkse samenleving en kon Turkije alleen vooruitgang boeken als de ontwikkeling gebaseerd was op de authentieke Turks-islamitische cultuur. Necip Fazıl en zijn aanhangers zochten nadrukkelijk de continuïteit met het Osmaanse verleden, die de kemalistische elite juist verwierp. Necip Fazıl formuleerde zijn cultuurpolitieke ideeën in tijdschriften in de jaren dertig en veertig en een van deze tijdschriften (uit 1943) droeg ook al de naam 'Het Grote Oosten' (Büyük Doğu) (Yavuz 2003: 114-6).

De IBDA-C is een zeer radicale organisatie, verwant aan sommige bewegingen in de Arabische wereld die aangeduid worden met de verzamelnaam Salafiyya en die als doel hebben een zuiver islamitische staat te stichten naar het voorbeeld van de 'vrome voorouders' (al-salafal-sâlih, waarvan de naam Salafiyya is afgeleid) (Shinar in EI2, vol. VIII: goob). De beweging erkent de Turkse republiek niet, maar wijst het Iraanse sjiitische regime eveneens af. Haar ideaal is een federatieve islamitische staat die de plaats van de natiestaten inneemt en zo de verdeeldheid in de islamitische wereld opheft. IBDA-C had een charismatische leider in haar oprichter Salih İzzet Erdiş, beter bekend onder zijn schuilnaam Salih Mirzabeyoğlu, die echter sinds 1998 in een Turkse gevangenis zit. Van zijn hand zijn vele geschriften bekend, die handelen over theoretische vraagstukken en over tactiek.

De organisatie van IBDA-C is ondoorzichtig. Er is een tak die openlijke activiteiten bedrijft, zoals het houden van demonstraties, het publiceren van tijdschrif- 
ten en het onderhouden van websites. Er is echter ook een in cellen georganiseerde ondergrondse organisatie die zich bezighoudt met 'de strijd', wat in feite neerkomt op aanslagen en ontvoeringen. Het is een platte organisatie, waarbinnen de cellen strikt van elkaar gescheiden zijn en vaak onafhankelijk opereren. De acties die de cellen ondernemen, passen in het concept van de 'gewapende propaganda', dat in de jaren zeventig ook door de linkse stadsguerrilla in Turkije veel werd toegepast. Het gaat hierbij om aanslagen op doelen met een hoge nieuwswaarde die relatief weinig militair risico opleveren, zoals secularistische kranten en journalisten, synagoges, een prominente joodse zakenman en een Grieks orthodoxe kerk (www.ict.org.il 4-12-2003). Hoogstwaarschijnlijk waren ook degenen die, al dan niet in samenwerking met al-Qaeda, in november 2003 in Istanbul de zelfmoordaanslagen pleegden, leden van IBDA-C.

\subsubsection{HIZBULLAH}

Een jongere, maar aanzienlijk grotere extremistisch-islamitische organisatie is de Hizbullah (Partij van God, de naam refereert aan een citaat in de koran). Deze beweging, die overigens niets te maken heeft met de sjiitische Hizbullah in Libanon, ontstond eind jaren tachtig in het Koerdische zuidoosten van Turkije, met als belangrijkste centra de provincies Batman en Diyarbakır, de 'hoofdstad' van het zuidoosten. Dit was de periode waarin de oorlog tussen het Turkse leger en de guerrillerastrijders van de PKK, snel escaleerde. De Hizbullah richtte zich in principe tegen beide partijen: haar ideaal is de vestiging van een onafhankelijke islamitische staat. In de praktijk richtte de terreur van de Hizbullah zich met name tegen de 'goddeloze' PKK en tegen progressieve Turkse en met name Koerdische zakenmensen en journalisten die van steun aan de PKK verdacht werden. Begin jaren negentig viel de organisatie in twee takken uiteen, die allebei genoemd werden naar boekhandels waar de aanhangers bijeenkwamen: de İlim (Kennis)-tak en de Menzil (Etappe)-tak. Het geweld was met name het werk van de İlim-tak (www.terrorism.com, 3-12-2003).

In de late jaren negentig kwamen er in Turkije steeds meer geruchten dat de İlimfactie van de Hizbullah zodanig was geïnfiltreerd door het Turkse veiligheidsapparaat dat zij in feite een instrument van de Turkse staat was geworden in diens strijd tegen de PKK (Zürcher 1995: 381-2). Dit leek bevestigd te worden toen de Turkse media, wellicht gevoed door rivaliserende inlichtingendiensten, bewijzen produceerden om aan te tonen dat de gouverneur van Batman op grote schaal illegale wapenimport had gepleegd. Na de gevangenneming van PKK-leider Abdullah Öcalan, begin 1999, die het feitelijke einde van de oorlog tegen de PKK inleidde, had de Turkse staat Hizbullah niet meer nodig en in het kader van de campagne tegen het fundamentalisme, die het leger vanaf februari 1997 had ingezet, werd nu ook hard opgetreden tegen de Hizbullah-militanten. De leider van de İlim-vleugel, Hüseyin Velioğlu, werd in Istanbul door de veiligheidsdienst gedood, waarna in een één jaar durende campagne ongeveer tweeduizend leden van de organisatie werden opgepakt en honderden in staat van beschuldiging werden gesteld. Hoe gruwelijk de erfenis van de Hizbullah was, bleek toen de 
politie op een aantal locaties in totaal ongeveer zeventig lijken terugvond van vermoorde Turkse en Koerdische zakenlieden en intellectuelen, die overduidelijk de sporen van marteling vertoonden.

Dat de Hizbullah door de veiligheidsdiensten niet volledig was opgerold, bleek in de jaren 2001-2002, toen de groep een aantal Turkse ambtenaren, onder wie de commissaris van Diyarbakır, vermoordde. De sterkte van Hizbullah wordt momenteel geschat op enkele honderden actieve leden.

\subsubsection{HET KALIFAAT VAN KEULEN}

De derde bekende organisatie met een duidelijk fundamentalistisch programma is de zogenaamde 'Kalifaatsstaat'. De stichter is Cemalettin Kaplan. Hij werd geboren in 1926 in een dorp in de provincie Erzurum en studeerde in 1966 in Ankara af aan een theologische hogeschool. Tot 1971 werkte hij als moefti in dienst van het Presidium voor Religieuze Zaken in Adana. In de jaren zeventig sloot hij zich aan bij de Nationale Visie-beweging van Necmettin Erbakan. Net als veel andere aanhangers van Milli Görüş verliet hij Turkije na de militaire machtsovername van september 1980 en het verbod op de toenmalige islamitische Nationale Heilspartij en vestigde zich in het Duitse Keulen. In 1983 scheidde hij zich af van de Nationale Visie-beweging, omdat hij inmiddels tot de overtuiging was gekomen dat deelname aan het democratische politieke systeem en islam niet verenigbaar waren. In Keulen stichtte hij de İsslamî Cemiyetler ve Cemaatler Birliği (Unie van Islamitische Verenigingen en Gemeenten), die in haar hoogtijdagen zo'n zevenduizend aanhangers had, onder wie ook Nederlandse Turken.

Kaplans boodschap was buitengewoon radicaal. Hij modelleerde zich naar Ayatollah Khomeini en riep zijn aanhangers op om de Turkse seculiere orde omver te werpen en een islamitische staat uit te roepen. Hij deed dit onder andere door, net als Khomeini in de jaren zeventig deed naar Iran, cassettebandjes naar Turkije te versturen, wat hem de bijnaam Kara Ses ('Zwarte Stem') opleverde. In de ogen van Kaplan moest dit een stap zijn op weg naar de vestiging van een islamitische wereldstaat met de koran als grondwet. Eind 1991 riep Kaplan zelfs de cihat (heilige oorlog) tegen de Republiek Turkije uit.

In april 1992 werd de Unie op een congres in Keulen omgezet in de 'Federale Islamitische Staat Anatolië' (Anadolu Federal İslamî Devleti), die in 1994 weer werd omgezet in de 'Kalifaatsstaat' (Hilafet Devleti) met Cemalettin Kaplan zelf als kalief. Niet al zijn volgelingen waren het met deze stappen eens en om greep op de beweging te behouden, bracht Kaplan alle materiële bezittingen van de beweging onder in een aparte, in Dordrecht gevestigde stichting: de Stichting Dienaar aan Islam.

Cemalettin Kaplan stierf in mei 1995, waarna zijn zoon Metin het ambt van kalief overnam. Onder hem is de beweging in een neerwaartse spiraal terechtgekomen. 
Een rivaal voor het kalifaat in Berlijn, die Metin niet wilde erkennen, werd na de afkondiging van een fetva (religieus advies) van Metin Kaplan door diens aanhangers vermoord, wat de kalief vier jaar gevangenisstraf opleverde. Nadat daar door Turkije al lange tijd om was gevraagd, werd de Kalifaatsstaat in 2001 uiteindelijk door de Duitse rechter verboden wegens het oproepen tot omverwerping van de constitutionele orde en het aanzetten tot haat. Desalniettemin gaan de activiteiten van de beweging, in Duitsland maar ook daarbuiten, nog steeds door. De bekendste propaganda-organen zijn het tijdschrift Ümmet- $i$ Muhammed (Gemeenschap van Mohammed) en de krant Beklenen Asr-i Saadet (De Verwachte Tijd der Gelukzaligheid), die ook in Nederland een kleine maar trouwe lezerskring hebben (www.im.nrw.de, 4-12-2003).

\subsection{CHRISTENEN EN JODEN IN TURKIJE}

\subsubsection{NIET-MOSLIMS BINNEN DE MOSLIMGEMEENSCHAP}

Volgens de bevolkingsstatistieken van Turkije, dat momenteel zo'n zeventig miljoen mensen telt, is ongeveer 99 procent van de bevolking moslim, alevieten inbegrepen. De verschillende christelijke bevolkingsgroepen samen maken ongeveer 0,3 procent uit van de bevolking; de joodse gemeenschap o,04 procent. De christelijke bevolking van Turkije bestaat, naast heel kleine groepen katholieken en protestanten, uit vier hoofdgroepen: de Grieks-orthodoxen, de Armeniërs, de Nestorianen en de Syrisch-orthodoxen. De leden van de eerste twee groepen wonen vrijwel allemaal in Istanbul, die van de twee laatstgenoemde naast in Istanbul ook in het zuidoosten van Turkije. De joodse gemeenschap is geconcentreerd in Istanbul (Sunier 1998: 47-8, 76).

De christelijke en joodse gemeenschappen in Turkije zijn dus vele malen kleiner dan de islamitische bevolkingsgroepen in bijvoorbeeld Nederland. Men kan zich dus afvragen of een bespreking van de positie van deze minuscule groepen een plaats dient te hebben in een schets van het religieuze landschap van Turkije. Tegelijkertijd laten gebeurtenissen uit het betrekkelijk recente verleden zien dat de positie van christenen in Turkije een kwestie is die politiek en maatschappelijk gevoelig ligt en die heftige emoties kan opwekken. Moties over de Turkse behandeling van Armeense christenen in het verleden zijn veelvuldig onderwerp van debat geweest, tot in het Amerikaanse congres en het Franse parlement toe. Sinds de jaren zeventig zijn joodse instellingen en vooraanstaande leden van de joodse gemeenschap in Turkije het doelwit geweest van aanslagen.

Ook Nederland is geconfronteerd met de spanningen en emoties die het probleem van de 'andersdenkenden' in Turkije oproept. Zo'n 25 jaar geleden stonden de Nederlandse kranten vol met berichten over kerkbezettingen in Twente, die het werk waren van Syrisch-orthodoxe immigranten, afkomstig uit het district Midyat, in Zuidoost-Turkije, die politiek asiel in Nederland zochten omdat zij in Turkije vervolgd zouden worden. Deze gebeurtenissen vestigden plotseling de aandacht op het feit dat het Twentse plaatsje Glanerbrug het reli- 
gieuze centrum van de Syrisch-orthodoxen in Europa was geworden. En nog maar enkele jaren geleden kwam de gemeente Assen in grote problemen omdat ze aan de Armeense gemeenschap in Assen toestemming had verleend voor de oprichting van een Armeens kruis, met als onderdeel een inscriptie waarin de slachtoffers van Turks geweld werden herdacht. Dit leidde tot felle Turkse protesten.

Om de schijnbare tegenstelling tussen de numerieke onbetekenendheid en de emotionele lading van het fenomeen 'christenen en joden in Turkije' te kunnen begrijpen, is een historische terugblik onvermijdelijk.

\subsubsection{DE 'MENSEN VAN HET BOEK'}

Vanaf het eerste begin van de Arabische veroveringen in de zevende eeuw hebben islamitische heersers een manier moeten vinden om grote groepen nietmoslims een plaats te geven in hun staten. De meerderheid van de bevolking in gebieden zoals Syrië of Egypte was immers christelijk en bekering tot de islam van grote delen van de bevolking is een heel geleidelijk proces geweest.

De religieus-juridische basis voor de omgang met de niet-moslims was het zogenaamde concept van de 'mensen van het boek'. Joden en christenen werden erkend als ontvangers van dezelfde goddelijke openbaring als de moslims, zij het dat de weergave van die openbaring in hun heilige schriften corrupt was en dat zij zelf afgedwaald waren van het rechte pad. Zij hadden in de ogen van moslims een fundamenteel andere positie dan bijvoorbeeld hindoes, boeddhisten, animisten of vuuraanbidders, die wel als echte 'heidenen' werden beschouwd. Gedwongen bekering van joden en christenen was in de islamitische staten uitzonderlijk. Als regel kregen de 'mensen van het boek' de status aangeboden van dhimmi (beschermeling). In ruil voor de betaling van een specifieke hoofdelijke belasting werd hun bestaan getolereerd en behielden zij in de afhandeling van de eigen interne aangelegenheden van de gemeenschap, onder het gezag van de eigen kerkelijke of rabbinale autoriteiten, een grote mate van autonomie.

Christenen en joden waren in het Osmaanse Rijk voor het midden van de negentiende eeuw niet gelijkberechtigd aan moslims. Hun tweederangs status werd zichtbaar tot uitdrukking gebracht door bouw- en kledingvoorschriften, het verbod op kerkklokken en op nieuwbouw van kerken, alsmede andere restricties. Het systeem leverde echter wel een mate van religieuze tolerantie op die in de meeste landen van Europa pas na de Franse Revolutie werd bereikt. Voor de Osmanen had het vestigen van een goede systematiek voor de omgang met christelijke minderheden een bijzonder belang, omdat zij, met name door hun veroveringen in Europa, uitgestrekte gebieden met een christelijke bevolking onder hun bestuur hadden gebracht. Midden negentiende eeuw was zo'n veertig procent van de Osmaanse bevolking christelijk en zelfs vlak voor de Eerste Wereldoorlog was dat nog altijd ongeveer twintig procent. De Osmaanse overheid liet ook op de dhimmis eenzelfde soort voorliefde voor reglementering en 
bureaucratisering los waarmee zij ook de islam probeerde te incorporeren in het eigen staatsapparaat.

In het Osmaanse Rijk werden de dhimmis van een bepaalde geloofsrichting collectief aangeduid als tayfa (gemeenschap) of millet (natie). Deze laatste term had in eerste instantie niet de politieke lading in de hedendaagse betekenis van het woord 'nationalisme'. De drie millets waarvan het bestaan door de Osmanen officieel werd erkend, waren de Grieks-orthodoxe, de Armeens-jacobitische en de joodse. Hoewel de term in theorie de hele collectiviteit van een bepaalde geloofsrichting dekte, had het zelfbestuur van de religieuze minderheden in feite een lokaal karakter, waarbij lokale religieuze leiders als intermediairs optraden tussen enerzijds de lokale vertegenwoordigers van de Osmaanse overheid en anderzijds hun eigen lokale gemeenschap. Tegenover de overheid waren de kerkelijke leiders verantwoordelijk voor de loyaliteit en het goede gedrag van hun volgelingen (Braude en Lewis 1982; Lewis 1996: 315-8).

\subsubsection{BUITENLANDERS EN PROTÉGÉS}

Naast autochtone christenen woonden er ook kleine groepen onderdanen van Europese staten in het Osmaanse Rijk, voornamelijk aanwezig voor het drijven van handel. Zij waren geconcentreerd in de belangrijkste handelscentra: natuurlijk Istanbul, maar ook in steden als Aleppo, Saloniki, Izmir, Akko en Beirut. Deze Europeanen waren geen onderdanen van de sultan en zij verbleven in het Osmaanse Rijk onder vrijgeleide (aman, letterlijk: 'genade'). Dit was noodzakelijk omdat volgens het islamitisch recht in principe de staat van oorlog heerste tussen de gebieden onder islamitisch bestuur (de dar ul-islam, of het 'huis van de islam') en de gebieden waarvoor dat (nog) niet gold (de dar ul-harb, ofwel het 'huis van de oorlog'). In theorie kon een vrijgeleide voor mensen afkomstig uit het 'huis van de oorlog' slechts voor een jaar gelden. In de praktijk echter verbleven Europeanen vaak vele jaren aaneen, en soms zelfs generaties lang, in het Osmaanse Rijk. De voorwaarden waarop zij konden verblijven en handel konden drijven, lagen vast in door de Osmaanse overheid als gunst aan de bevriende Europese staten verleende ahdnames ('brieven van belofte'), in het Westen (omdat zij in hoofdstukken of capitels waren ingedeeld) bekend als de 'capitulaties' (De Groot 1986: 7-9).

Tot de voorrechten die door de sultans werden verleend, behoorde, naast belastingvoordeel een zekere mate van extraterritorialiteit. De hoofden van de buitenlandse gemeenschappen: de consuls of, in Istanbul, de ambassadeurs, werden gemachtigd om zaken die alleen de leden van hun eigen natie betroffen zelfstandig en volgens het eigen, bijvoorbeeld Franse, Engelse of Nederlandse recht te regelen. Om contact te kunnen onderhouden met de Osmaanse autoriteiten namen de vertegenwoordigers van de Europese staten tolken in dienst, de zogenaamde 'dragomans', die vrijwel altijd tot de autochtone christelijke bevolkingsgroepen behoorden. Omdat het hierbij om vertrouwensfuncties ging, stond de Osmaanse overheid toe dat deze lokale christenen onder de protectie 
stonden van de betreffende Europese ambassade en werden beschouwd als behorende tot de natie van de betreffende ambassadeur of consul. Deze status werd aan de dragomans en hun families verleend met een zogenaamd 'diploma' (berat).

Vanaf de late achttiende eeuw verzwakte de militaire en politieke positie van het Osmaanse Rijk ten opzichte van zijn christelijke buren. Tegelijk begon in diezelfde periode de handel met Europa sterk te groeien. Deze conjunctuur leidde ertoe dat het systeem van de capitulaties en dat van het millet-systeem in elkaar konden vloeien. De bescherming van een grote Europese mogendheid werd steeds waardevoller naarmate de macht van die mogendheid ten opzichte van het Osmaanse Rijk groeide. Voor de autochtone christelijke handelaren, met name de Griekse, die actief waren of werden in de handel met Europa, leverde het honoraire staatsburgerschap van een Europese mogendheid zekerheid en belastingvoordelen op. Voor de Europese staten vormden deze protégés een aantrekkelijke groep cliënten die hun machtsbasis in de Levant versterkten. Aangezien voor de berats, die de status van protégé verleenden, vaak veel geld werd neergeteld, was de uitgifte ervan voor Osmaanse autoriteiten verleidelijk. Tussen 1770 en 1850 groeide het aantal Osmaanse christenen en joden met een berat dan ook explosief: van hooguit enkele duizenden tot honderdduizenden.

In de negentiende eeuw ontstond in het Osmaanse Rijk, vooral in de kustgebieden, een flinke moderne commerciële en industriële sector die volledig werd gedomineerd door de christelijke, en soms joodse, beschermelingen van de Europese mogendheden. Zij vormden een bourgeoisie die zich ook in levenstijl geheel modelleerde naar Londen en Parijs. Daar stond tegenover dat de Osmaanse regeringen vanaf de jaren dertig van de negentiende eeuw het staatsapparaat en het leger gingen hervormen om de groeiende macht van Europa het hoofd te bieden. Het model dat hen daarbij voor ogen stond, was dat van de gecentraliseerde bureaucratische staat met een groot leger van dienstplichtigen. In de loop van de negentiende eeuw raakte de Osmaanse maatschappij dan ook gepolariseerd, waarbij de twee polen werden gevormd door aan de ene kant een groeiende christelijke, en voor een klein deel joodse bourgeoisie en aan de andere kant een door moslims gedomineerd staatsapparaat.

In de negentiende eeuw streefden de christelijke minderheden in het Osmaanse rijk drie verschillende en totaal onverenigbare doelen na. Het eerste was gelijk burgerschap binnen de Osmaanse staat, dat wil zeggen gelijke rechten als de moslimmeerderheid. De Europese mogendheden drongen bij de Turken sterk aan op het idee van gelijke burgerrechten ongeacht godsdienst, soms in flagrante tegenstelling tot de gang van zaken in hun eigen gebied. In 1856 kende de Osmaanse regering deze gelijkberechtiging van onderdanen officieel toe. De pogingen in de jaren zestig, vooral van de kant van de jongere leden van de Osmaanse bureaucratie, om ook een gevoel van nationale identiteit te doen ontstaan, in de vorm van een Osmaans patriottisme dat door alle gemeenschappen gelijkelijk zou kunnen worden gedeeld, mislukten echter. De combinatie 
van autonomie, buitenlandse bescherming en groeiende welvaart gaf christenen de gelegenheid hun eigen gemeenschapszin te ontwikkelen, met eigen media, publieke ruimtes en verenigingen. Daar ontwikkelden de diverse nationalismen zich tot een steeds sterkere kracht.

Het tweede doel waar steeds meer Osmaanse christenen met toenemende energie naar streefden, was onafhankelijkheid, of in ieder geval autonomie binnen een eigen nationaal grondgebied. In de loop van de negentiende en het begin van de twintigste eeuw slaagden eerst de Serviërs en de Grieken en vervolgens de Roemenen, Bulgaren, Montenegrijnen en Albanezen erin om soevereine onafhankelijke staten te vestigen op wat zij beschouwden als een deel van het nationale grondgebied. Ook onder de in Anatolië wonende Armeniërs werd vanaf ongeveer 1880 een nationalistische beweging actief. Het derde doel van de christenen, naast gelijkberechtiging en nationalistische aspiraties, was het behouden van de privileges en autonomie die de millets onder de oude orde hadden: het recht op handhaving en uitvoering van de eigen religieuze wetten en op eigen onderwijssystemen in hun eigen taal en, in het algemeen, het recht om hun eigen kenmerkende cultuur te bewaren (Lewis 1996: 316-8).

\subsubsection{ETNO-RELIGIEUZE CONFLICTEN}

Oog in oog met de, zijns inziens, twijfelachtige loyaliteit van de christelijke onderdanen, die al in de desastreuze oorlog tegen Rusland van 1877-1878 aan het licht was gekomen, probeerde sultan Abdülhamit II een hechtere basis voor zijn regime te creëren door het nadrukkelijk als islamitisch te profileren. Hiermee werd een, tot op zekere hoogte succesvol, beroep gedaan op de islamitische bevolking, die na 1878 zo'n tachtig procent van de totale bevolking uitmaakte, maar het vervreemdde de niet-moslimse minderheden natuurlijk nog verder van de staat.

De oppositie die vanaf de jaren negentig tegen het regime van de sultan groeide, was eigenlijk een monsterverbond. Aan de ene kant werd deze gevormd door leden van minderheidsgroepen, die decentralisatie en meer autonomie verlangden, aan de andere kant door jonge moslimbureaucraten en militairen die juist de uitholling van de macht van de staat die zij dienden een halt toe wilden roepen. Deze tegenstelling bleek heel duidelijk toen een groep jonge bureaucraten en militairen, de zogenaamde Jong Turken, in 1908-1909 een eind maakte aan het autocratische regime van sultan Abdülhamit. Toen de euforie voorbij was, laaiden de tegenstellingen tussen de beide groepen al snel op.

De Balkanoorlog van 1912-1913 bleek uiteindelijk het breekpunt. In die oorlog verloor het Osmaanse Rijk bijna al zijn Europese grondgebied. Bovendien ging het daarbij om gebieden vanwaaruit een onevenredig groot deel van de politieke en militaire leiding afkomstig was, zoals bijvoorbeeld ook Mustafa Kemal Pasja. In de Balkanoorlog was Griekenland een van de tegenstanders van de Osmanen en veel Osmaanse Grieken hoopten op een Osmaanse nederlaag. De verdrijving 
van honderdduizenden moslims uit de Balkan leidde op haar beurt weer tot represailles van Osmaanse zijde. Zo'n 130.000 Grieken van de Anatolische westkust werden in 1914 het land uitgezet.

Verdergaande repercussies waren er tijdens de Eerste Wereldoorlog. Doordat het Osmaanse Rijk in oorlog kwam met Engeland, Frankrijk en Rusland, verviel de mogelijkheid van die staten om hun protégés in het rijk te beschermen. Dit gaf het Jong Turkse regime de gelegenheid te proberen om baas in eigen huis te worden. Op economisch gebied betekende dit de ontwikkeling van een politiek die er consequent op was gericht om de minderheden hun quasi-monopolie in de moderne sector van de economie te ontnemen en een eigen klasse van moslimondernemers te creëren.

Naast discriminatie werden door het regime echter ook deportatie en vervolging als middelen ingezet. Toen sommige groepen Armeniërs de kant van Rusland kozen en het Osmaanse leger aanvielen, was dat voor de Jong Turken, vastbesloten om dat wat in de Balkan was gebeurd niet opnieuw in Anatolië te laten gebeuren, een aanleiding om vrijwel de gehele Armeense bevolking onder barre omstandigheden naar de Syrische woestijn te deporteren. De deportaties werden bovendien gebruikt voor het uitvoeren van massale slachtpartijen onder de Armeniërs. In totaal kwamen hierbij waarschijnlijk zo'n 60o.0oo-80o.0oo Armeniërs om. Armeense strijdgroepen die met het Russische leger meekwamen, lieten zich echter ook niet onbetuigd.

Ook na de Eerste Wereldoorlog bleef de allesoverheersende scheidslijn tussen Osmaanse moslims en Osmaanse christenen bestaan. De verzetsbeweging die onder leiding van Mustafa Kemal Pasja in Anatolië op gang kwam, verzette zich tegen de opdeling van het Osmaanse Rijk, zoals vastgelegd op de vredesconferentie in Parijs. Daarmee kwam ze in conflict met Groot-Brittannië en Frankrijk, maar de feitelijke gewapende strijd werd gevoerd tegen de Armeniërs en de Grieken, die grote delen van Anatolië claimden. In deze strijd werd van beide zijden meedogenloos opgetreden tegen de burgerbevolking. Toen de Turkse nationalisten de oorlog tegen de Armeniërs (in 1920) en tegen de Grieken (in 1922) wonnen, was voor beide partijen in het conflict duidelijk dat de verhouding tussen de moslims en de christenen zodanig was geworden dat zij niet goed meer in één land konden samenwonen. De Griekse bevolking in het westen van Anatolië vluchtte massaal weg. Tijdens de vredesonderhandelingen in Lausanne (1923), waar het huidige Turkije op de kaart werd gezet, bereikten Griekenland en Turkije onder de auspiciën van de Volkenbond een overeenkomst om de resterende moslims uit Griekenland te ruilen tegen de achtergebleven Grieks-orthodoxen in Turkije. De uitwisseling had voor de bevolking een gedwongen karakter en de 'Griekse' bevolking van Midden-Anatolië, die voor een belangrijk deel Turkstalig was, en die van de Zwarte-Zeekust verlieten daarop ook het land. Alles bij elkaar ging het om een groot aantal mensen: in 1922-1924 verlieten in totaal zo'n 1,2 miljoen Grieken het land. Er kwamen circa 400.ooo moslims voor terug. De enige niet-islamitische groepen van enige betekenis die achterbleven, waren 
de Grieken die konden aantonen dat zij al voor 1912 in Istanbul woonden, de Armeense gemeenschap in Istanbul, de joden van Istanbul (zowel sefardisch als asjkenazisch) en de katholieke en protestante gemeentes, van wie de meeste leden buitenlandse paspoorten hadden. De Griekse gemeenschap in Istanbul was in 1924 met meer dan 100.000 leden met afstand de grootste van deze restgroepen.

\subsubsection{NIET-MOSLIMS TIJDENS DE REPUBLIEK}

In de artikelen 38 tot en met 44 van het Verdrag van Lausanne werden de nietmoslims (gayrimüslim) officieel als minderheden erkend en werden hun rechten in de nieuwe republiek internationaal bindend vastgelegd. Zij zijn daarmee de enige bevolkingsgroepen van Turkije waarvoor dit gold en geldt. Behalve een verbod op discriminatie en een garantie van godsdienstvrijheid gaven deze artikelen de minderheden ook het recht op het gebruik van de eigen taal en op eigen onderwijsinstellingen (Parla 1985: 8-10).

De seculariseringspolitiek van de republiek, die natuurlijk in de eerste plaats op de islam gericht was, werd in principe door de christelijke en joodse minderheden verwelkomd. De trauma's van de moslimbevolking zaten echter diep. Het nationalistische regime van de republiek was voortgekomen uit een beweging die de rechten van de moslims verdedigde tegen die van de lokale en buitenlandse christenen. De semi-koloniale situatie, waarin de hele moderne sector van de economie werd beheerst door christelijke beschermelingen van Europese staten en waarbij bijvoorbeeld bij de Ottomaanse Bank moslims niet hoger kwamen dan de rangen van schoonmakers en portiers, lag nog vers in het geheugen. Bovendien was de afhankelijkheid van de minderheden niet alleen iets van het (recente) verleden. Het aanleren van de moderne vaardigheden, waardoor de moslims de plaatsen van de christenen en joden zouden kunnen innemen, kostte meer dan een generatie. In Anatolië betekende dit dat er op veel plekken nauwelijks nog bekwame ingenieurs of managers waren, of obers, lassers of elektriciens. In Istanbul, waar de minderheden grotendeels hadden kunnen blijven wonen, bleven deze minderheden in dit soort vakken, maar ook in de middenstand tot in de jaren vijftig van de twintigste eeuw, dominant. De onvrede hierover gaf al in de jaren twintig aanleiding tot discriminerende maatregelen. Wanneer buitenlandse ondernemingen, zoals de spoorwegen, door de Turkse staat werden overgenomen, werd die gelegenheid vaak gebruikt om zoveel mogelijk christelijke en joodse werknemers te vervangen door moslims (Bali 1999: 206 ff).

Het hoeft geen verbazing te wekken dat dit soort tendensen bij de minderheden een zekere mate van twijfel lieten voortbestaan over het werkelijke neutrale en seculiere karakter van de republiek. De ergste vermoedens werden bevestigd gedurende de Tweede Wereldoorlog. Deze oorlog bracht in het neutrale Turkije grote economische problemen en verarming teweeg, wat, ook in aan de regeringspartij gelieerde media, werd geweten aan de Griekse, Armeense en joodse 
zakenlieden. Het gevolg was de invoering in 1942 van een vermogensbelasting (de Varlkk Vergisi), waarvan de heffing werd overgelaten aan lokale comités. Deze zorgden ervoor dat de belasting werd afgewenteld op de minderheden, die vaak een tien keer zo hoog percentage moesten betalen als de moslims. Bovendien mochten zij niet gespreid betalen, wat ertoe leidde dat velen hun zaken onder heel ongunstige omstandigheden moesten verkopen. Degenen die niet konden betalen, werden gedeporteerd naar werkkampen in Oost-Anatolië. De wet werd in 1944 ingetrokken, maar toen was de schade aan het vertrouwen van de minderheden in de Turkse staat al aangericht. Na de oorlog begon dan ook een gestage emigratie.

De eerste groep die massaal emigreerde, was de joodse. Weliswaar had Turkije in de Tweede Wereldoorlog vele Europese joden doorgang verleend naar Palestina en ook aan enkele tienduizenden onderdak geboden, maar de joden hadden net als de andere minderheden te lijden gehad van de Varlik Vergisi. Bovendien was het klimaat al voor de oorlog verslechterd: kort na Hitlers machtsovername in 1934 waren in Europees Turkije al door nazi-sympathisanten geïnspireerde jodenvervolgingen geweest (Bali 1999: 243). De oprichting van de staat Israël in 1948 bleek dan ook voor veel Turkse joden reden om het land te verlaten. Van ongeveer 8o.ooo joden na de oorlog, kromp de joodse gemeenschap tot minder dan 50.000 in 1955. Dit aantal bleef gestaag dalen tot de overwinning van Israël in de Zesdaagse Oorlog van 1967, waardoor een tweede emigratiegolf het aantal nog eens halveerde.

Momenteel wonen in Turkije nog ongeveer 18.000 joden, van wie het overgrote deel in Istanbul. Zij spelen nog steeds een relatief belangrijke rol in de zakenwereld, maar benadrukken hun joodse identiteit niet. Aanslagen op joodse doelen door radicaal-linkse of fundamentalistische groepen, met name op de grote synagoge van Istanbul, die sinds 1989 al drie keer is aangevallen, hebben de angst zich bloot te geven, vergroot. Ook de opkomst van de Welvaartspartij in het begin van de jaren negentig was voor de joden bedreigend, omdat er in die partij een duidelijk herkenbare onderstroom van antisemitisme bestond die antiIsraëlische retoriek verbond met lofprijzingen voor Hitler en verwijzingen naar een joodse samenzwering die politiek van de vs en de EU zou bepalen (Erbakan 1975: 235-64; Poulton 1997: 279-81).

De enige uitzondering op het 'low profile' van de joodse gemeenschap is de herleving van de belangstelling voor de (tien jaar geleden vrijwel uitgestorven) Spaanstalige (Ladino) cultuur van de sefardische joden die eind vijftiende eeuw in Turkije een veilig onderkomen hadden gevonden. De viering van vijfhonderd jaar joodse immigratie in 1992 was het startsignaal voor deze beweging, die natuurlijk vanwege het accent op de tradities van tolerantie en godsdienstvrijheid in Turkije, de staat zeer welgevallig was. Inmiddels is er weer veel aandacht voor met name de sefardische muziek. 
De Griekse minderheid herstelde zich in de jaren na de Tweede Wereldoorlog, toen de relaties tussen Turkije en Griekenland warm waren, maar hieraan kwam abrupt een eind door de crisis die midden jaren vijftig uitbrak over de toekomst van het eiland Cyprus. Om de diplomatieke druk op de Grieken op te voeren, liet de Turkse regering van Menderes in 1955 demonstraties houden tegen de onderdrukking van de Turkse minderheid op Cyprus. Deze liepen op 6-7 september 1955 uit op een anti-Griekse pogrom, waarbij doden vielen en talloze Griekse woonhuizen en winkels geplunderd en in brand werden gestoken. Scholen, kerken en begraafplaatsen werden ook het slachtoffer van de volkswoede. Het gevolg was dat de Grieken op dat moment definitief hun vertrouwen in de republiek verloren. Er begon een migratiestroom die niet meer is opgehouden. Van de 100.000 tot 150.000 Grieken die er in 1923 in Istanbul woonden, zijn er nu niet meer dan 3.000 tot 4.000 over.

De grootste religieuze minderheid in Turkije is nu, ironisch genoeg, juist diegene die het in het verleden het zwaarst te verduren heeft gehad, namelijk de Armeense. Zij hebben net als de Grieks-orthodoxen te lijden gehad van de, soms door de staat aangewakkerde, ressentimenten onder de moslimbevolking en in de jaren zeventig en tachtig werden zij soms het slachtoffer van represailles voor de wereldwijde campagne van aanslagen op Turkse doelen door het Armeense Bevrijdingsleger (ASALA). Toch heeft de Armeense gemeenschap nu nog een omvang van 30.000 tot 35.000 in Istanbul.

De kleine christelijke gemeenschappen in het zuidoosten, Nestorianen en Syrisch-orthodoxen, hebben het sinds de jaren zeventig buitengewoon moeilijk gekregen, ingeklemd als zij zaten tussen het Turkse leger, radicale moslims van de Hizbullah en Koerdische guerrillastrijders. Dit deed de economische omstandigheden in dit toch al armste deel van het land geen goed en deze gemeenschappen zijn dan ook vrijwel geheel naar het relatief veilige Istanbul of naar Europa gemigreerd. De Syrische gemeenschap in Twente is hiervan een voorbeeld (Poulton 1997: 272-8).

\subsubsection{IS EEN TURK EEN MOSLIM?}

De hier beschreven lotgevallen van de niet-islamitische minderheden roepen natuurlijk de vraag op in hoeverre christenen en joden ook werkelijk als volwaardige Turkse burgers worden beschouwd en in hoeverre zij zichzelf zo beschouwen.

Op het formele niveau is de situatie heel helder. De Turkse staat en wetgeving discrimineren niet op basis van religie. Nog steeds wordt in essentie de Turkse nationaliteit gedefinieerd op basis van de principes van Atatürk uit de jaren dertig: "Iedereen binnen de Republiek Turkije, welke religie hij ook aanhangt, is een Turk als hij Turks spreekt, in de Turkse cultuur opgroeit en het Turkse ideaal omarmt" (Zürcher in Georgeon (ed.) 2000: 6o). Tegelijk heeft de negentiendeen vroeg-twintigste-eeuwse geschiedenis in Turkije een zekere 'belegeringsmen- 
taliteit' doen postvatten: een idee dat buitenlandse krachten erop uit zijn om het land te verzwakken of zelfs op te delen en dat zij daarbij gebruikmaken van vijfde colonnes in Turkije. Men voelt zich gauw bedreigd. In de afgelopen twintig jaar heeft de oorlog tegen de PKK deze tendens versterkt. De neiging minderheden te zien als handlangers van buitenlandse vijanden is dan ook altijd aanwezig.

Daarnaast is het ook voor de leden van de minderheidsgroepen niet altijd gemakkelijk zich echt als volwaardig Turks staatsburger te beschouwen. In dat opzicht is natuurlijk de omarming van de soennitische islam als deel van de nationalistische staatsideologie, zoals die vanaf 1980 heeft plaatsgevonden, absoluut schadelijk geweest voor hun integratie. De overgrote meerderheid van de christenen en joden heeft met de voeten gestemd en is geëmigreerd. Ook dat heeft de positie van de achterblijvers ernstig verzwakt. 


\section{DE TURKSE ISLAM EN DE EU: BOTSING DER BESCHAVINGEN?}

In het voorgaande deel van deze studie hebben we kennis kunnen maken met een aantal belangrijke karakteristieken van de Turkse islam en tegelijk met de grote geschakeerdheid van het Turkse religieuze landschap. In dit hoofdstuk willen we een antwoord geven op de vraag in hoeverre het gegeven dat Turkije een islamitisch land is een onoverkomelijke hinderpaal zal blijken voor het lidmaatschap van de EU. Met andere woorden: staat de Turkse islam toetreding tot de EU in de weg? Die discussie speelt zich af in de bredere context van een andere, namelijk die over de vraag welke plaats dit landschap toekomt in een discussie over een 'Botsing der Beschavingen'. Impliciet komt daarmee het realiteitsgehalte ter discussie te staan van dit door Samuel Huntington in 1993 gelanceerde en inmiddels vooral in politiek en journalistiek wijdverbreide paradigma.

\subsection{MODERN VERSUS WESTERS}

Kenmerkend voor Huntingtons benadering is, naast de indeling van de wereld in 'beschavingen', het onderscheid dat hij maakt tussen het Westen en de moderniteit, of anders gezegd: tussen verwestersing en modernisering. De moderniseringsprocessen die zich sinds de achttiende eeuw hebben voorgedaan, en waarvan industrialisatie, urbanisatie, geletterdheid, onderwijs, welvaart, een steeds verfijndere arbeidsdeling en sociale mobilisatie aspecten vormen, hebben hun wortels in de Europese beschaving, de eerste die moderniseerde. Modernisatie is een revolutionair proces dat in principe universeel is. Landen als Japan en China bewijzen dat landen uit verschillende beschavingsgebieden een succesvol moderniseringsproces kunnen ondergaan. Daar volgt volgens Huntington echter niet uit dat de westerse cultuur daarmee ook een universele cultuur wordt. De identificatie 'modern is westers' wordt door hem uitdrukkelijk afgewezen. Hij gelooft met 'Botsing der Beschavingen' niet langer (zoals hij eerder wel deed) dat met de voortschrijdende modernisatie ook de waarden die kenmerkend zijn voor de westerse beschaving universeel zullen worden. De verklaring hiervoor zoekt hij in het feit dat de westerse beschaving is gevormd in de tijd die voorafging aan het begin van het modernisatieproces van de zeventiende en achttiende eeuw. Het Westen was al het Westen voordat het modern werd. Andere delen van de wereld hebben deel aan het moderniseringsproces, zonder dat zij de culturele erfenis van het pre-moderne Westen in hun bagage hebben (Huntington 2003: 67-71).

De historische ingrediënten die samen de westerse beschaving haar kenmerkende eigenschappen hebben gegeven, zijn volgens Huntington: de klassieke erfenis, katholicisme en protestantisme, de rijkdom aan talen, de scheiding van geestelijke en wereldlijke macht, de ontwikkeling van het recht, sociaal pluralisme (standenmaatschappij), vertegenwoordigende lichamen en individualisme. Deze ingrediënten houden onderling verband: het sociale pluralisme 
heeft de opkomst van vertegenwoordigende lichamen bevorderd en veel van de kenmerken van de westerse beschaving hebben uiteindelijk bijgedragen aan het belang dat in het Westen aan het individu wordt gehecht (Huntington 2003: 71-4).

Anders dan het proces van modernisering heeft de westerse beschaving dus duidelijke grenzen, namelijk de grenzen waarbinnen de bovengenoemde historische factoren werkzaam zijn geweest. Huntington zegt het zo: "Europa houdt op waar het westerse christendom ophoudt en waar de islam en het orthodoxe christendom beginnen" (2003: 170). Het is vooral deze redenering die haar politieke vertaling heeft gekregen in uitlatingen van mensen als Bolkestein, Giscard d'Estaing, Kohl en Martens, die stuk voor stuk hebben gesteld dat Turkije niet tot de EU moet toetreden, omdat het geen deel uitmaakt van de westerse of Europese beschaving.

De opvatting dat Europa een historisch gegroeide beschaving is en dat daaruit de politieke consequentie getrokken moet worden dat de buitengrenzen van de EU dat beschavingsgebied niet te buiten mogen gaan, is een zeer problematische. Om te beginnen voldoen ook de huidige leden en kandidaat-leden niet steeds aan de criteria van Huntington. De invloed van katholicisme en protestantisme is in Griekenland tenslotte vrij ver te zoeken. Wat is (in de pre-moderne tijd) de invloed van de klassieke beschaving in Finland? Tegelijk hebben ook landen die door Huntington in het beschavingsgebied van de islam worden ingedeeld, zoals Turkije of Syrië, wel degelijk deel gehad aan zaken als de klassieke cultuur. Dat deze gebieden onder Arabisch of later Turks bestuur zijn komen te staan, doet daaraan niets af, tenzij men de - historisch volstrekt onjuiste - bewering aan zou durven dat de oorspronkelijke bewoners na de Arabische en Turkse veroveringen massaal zouden zijn weggetrokken.

Erger is dat de criteria die Huntington hanteert, getuigen van onwetendheid over andere beschavingen, met name die van de islam (die door Huntington toch als de grote tegenspeler van 'het Westen' wordt gezien). Het is een gotspe te beweren dat de klassieke erfenis in de wereld van de islam een minder grote rol heeft gespeeld dan in de westerse wereld, waar nota bene het doorgeven van die erfenis aan het middeleeuwse Europa voor een belangrijk deel afhankelijk is geweest van de Arabische vertalingen van en commentaren op de klassieken. De veelheid aan talen, die zo exclusief karakteristiek zou zijn voor Europa, is geen overtuigend argument voor wie zich bezighoudt met de Kaukasus of Indonesië. De uitspraak dat het recht in andere beschavingsgebieden, waaronder het islamitische, veel minder een bepalende factor is geweest bij de vorming van gedachtegoed en gedrag is ronduit bizar voor wie enigszins vertrouwd is met de fixatie van de islamitische maatschappijen op de regelgeving van de heilige wet. De enorme verbreiding en het belang van het instituut van de juridisch adviseur, de moefti, in de gehele islamitische wereld en over een periode van meer dan duizend jaar logenstraft deze bewering al. 
Dit is natuurlijk algemene kritiek op de empirische basis en de theoretische uitgangspunten van Huntington. Bij nadere beschouwing blijken de grenzen tussen de beschavingsblokken grijs en poreus. Maar wat valt er te zeggen over de specifieke positie van Turkije in het licht van de 'Botsing der Beschavingen'?

\subsection{DE POSITIE VAN TURKIJE}

Huntington rangschikt Turkije onder de 'verscheurde landen'. Dit zijn landen waarvan de elite de ambitie heeft over te stappen van één beschavingsgebied naar een ander. Dit kan in zijn ogen alleen slagen als én de elite van het land hiervoor enthousiast is én de bevolking de overstap accepteert én de ontvangende beschaving het land op wil nemen. Hij constateert dat een zodanige herschepping van identiteit een langdurig, stapsgewijs en pijnlijk proces is, dat tot dusverre nog nooit is geslaagd (Huntington 2003: 148). Huntington oppert zelf echter ook dat door het grote verspreidingsgebied van de islam er vele onderscheiden culturen of subbeschavingen binnen de islam bestaan, waaronder de Arabische, Turkse, Perzische en Maleisische (Huntington 2003: 44-5). Ofwel, door bepaalde factoren ontstaan varianten binnen een zogenaamde 'hoofdbeschaving'.

Eerder (par. 2.1.2) typeerden wij de Osmaans-islamitische erfenis van de Republiek Turkije als op haar beurt weer een traditie die put uit twee heel verschillende en deels zelfs tegenstrijdige bronnen. Ten eerste de islamitische wortels van de maatschappij en ten tweede de Turkse traditie van staatsvorming en staatsinrichting zoals die vanaf de zesde eeuw in Centraal-Azië, en vanaf de tiende eeuw in het Midden-Oosten vorm heeft gekregen. Daarnaast vermengden de militaire en politieke tradities die de Turken hadden ontwikkeld zich in de grensgebieden tussen het Midden-Oosten en Centraal-Azië met de oude Perzische koningstraditie, die een zwaar accent legde op de onafhankelijke autoriteit van de vorst.

Vervolgens benadrukten we dat de Osmanen erin slaagden de islamitische en de Turks-Perzische tradities in één bestuurlijk systeem met elkaar te verenigen. Officieel was het Osmaanse Rijk een islamitische staat met als formele basis de şeriat, de goddelijke wet. In de praktijk kondigden sultans ingewikkeld in elkaar gezette reguleringen af, bekend als kanun, die de zaken van een provincie of departement regelden, of van de monarchie en de centrale regering zelf. Een kanun kon op geen enkele manier de şeriat teniet doen of afschaffen, maar kon deze wel aanvullen en moderniseren door gebruik te maken van plaatselijke gewoonten en van verordeningen van regeerders (Lewis 1996: 223-4).

Gezegd zou dus kunnen worden dat de Osmaanse erfenis ook al voor de periode van de modernisering zich kenmerkte door een samengaan van verschillende systemen en tradities op diverse vlakken, aangepast aan de praktijksituaties waar de Osmanen mee te maken hadden. In de terminologie van Huntington zou binnen de politieke entiteit van het Osmaanse Rijk dan geen sprake zijn van 'Botsing der Beschavingen', maar juist van een pragmatisch 'samenstellen der 
beschavingen'. De omgang met heterodoxe minderheden en de behandeling van christenen en joden toont dezelfde pragmatische instelling.

Cemal Kafadar (1995) zegt over de Osmaanse 'identiteitskwestie’ het volgende.

"The Ottoman state/identity was not a lid that closed upon already formed national identities (of Arabs, Bulgarians, Turks, etc.) only to be toppled after a few centuries when those identities reasserted themselves. Some of these identities were formed to some extent, but they were reshaped (some might say, de-formed) under the aegis of, through the structures of, in response or reaction to, the Ottoman Empire. This is not a question of Ottoman influence but of a long and formative historical experience that shaped various communities and peoples under Ottoman rule through their interaction with each other as well as with peoples and ideas from neighbouring civilizations. So the establishment of Ottoman rule in southwestern Asia and southeastern Europe, even if one sees it in black-and-white terms - namely, as either a yoke or a blessing - did mean much more than a lapse in what would otherwise have been the natural flow of the history of a given set of nations. Ottoman rule is part of the history of various communities, some of whom were able (and some unable) to shape and imagine themselves into a nation in the modern era thanks to a 'historical consciousness' of their own (real or imagined) pre-Ottoman identity on the one hand and to the long and formative historical experience mentioned above on the other. (...) Historians tend to overlook the fact that (America is not the only case where) one is not necessarily born into a people; one may also become of a people, within a socially constructed dialectic of inclusions and exclusions" (Kafadar 1995: 22-7).

Verderop legt hij een van de hete hangijzers neer die ten grondslag liggen aan de verschillende interpretaties betreffende de 'state building' van de Osmanen.

“(...) The creation of the Ottoman administrative apparatus has been particularly controversial, with some historians arguing that it was all based on Byzantine models and others that the Ottomans could find all they needed in the Turco-Muslim heritage. In terms of broader cultural exchange or 'lifestyles' too, various sides of nationalist polemics have tended to see the influence of their side in, say, shared musical or culinary practices. The problem with both sides of this debate stems partly from their adherence to a static notion of cultural 'goods', whether one conceives of them in the realm of state building or cooking. In other words, 'influence' is understood as a creative party giving one of its own 'goods' to an imitating, uncreative other - a notion that needs to be recast now that historians realize influence is not possible without interaction, without a choice by the allegedly passive receiver. And even then, common cultural traits are not necessarily reducable to influence" (Kafadar 1995: 24).

De observaties van Kafadar, die vooral betrekking hebben op het ontstaan van het Osmaanse rijk in Anatolië, gelden evenzeer voor de vijf eeuwen van Osmaanse aanwezigheid in Zuidoost-Europa. Het is bij tegenstanders van toetreding van Turkije tot de EU gemeengoed geworden om die Osmaanse aanwezigheid als een vreemde overheersing af te doen - een bij uitstek buitenEuropees juk, waaronder Grieken, Bulgaren, Serviërs en Hongaren, Roemenen 
en Albanezen honderden jaren hebben gezucht. Dit beeld, dat zowel wortelt in de eeuwenoude Europese angst voor 'de Turk', de zogenaamde Turca Terribilis (De Groot 1986: 1), die in de vroegmoderne tijd immers de enige sterke tegenstander van de staten van Europa was, alsook in de nationalistische herschrijving van de geschiedenis van de Balkan sinds de negentiende eeuw, is evenzeer onjuist. Ook hiervoor geldt dat het Osmaanse verleden deel uitmaakt van het eigen culturele erfgoed van de regio en omgekeerd dat de Osmaanse cultuur mede is gevormd door invloeden vanuit diezelfde regio.

En dan komen we weer terug op de stelling van Huntington dat Turkije een 'verscheurd land' zou zijn dat over wil stappen van de ene beschaving naar de andere: van de islamitische naar de westerse. Volgens zijn theorie zou in dit geval van de drie voorwaarden tot slagen de 'bottleneck' worden gevormd door de onwil van de ontvangende beschaving. In dit geval de onwil van de EU om Turkije op te nemen. Het is dus hier eigenlijk het Westen dat de Turkse 'verscheuring' veroorzaakt en niet de Turkse elite of de Turkse bevolking, want die spreekt zich immers volgens de peilingen van opeenvolgende Eurobarometers in overgrote meerderheid ( $70 \%$ of meer) uit voor deelname aan de Unie.

Als Huntingtons beschavingsblokken bestaan, betekent dit dat de islamitische Turken niet alleen willens en wetens van het 'huis van de islam' overstappen naar het westerse 'huis van de oorlog', maar nog bereid zijn daar hun uiterste best voor te doen ook. Dit lijkt allerminst een logische stap. Zou het dus niet gewoon zo zijn dat het seculiere Turkije, volgende op alle historische, maatschappelijke en sociaal-economische ontwikkelingen in het Osmaanse Rijk en de republiek, van ideeën en praktijk, een volgend besluit heeft genomen dat berust op rationele en pragmatische motieven? Zouden we tegelijk niet moeten zeggen dat het Westen, hier de EU, weliswaar met de Kopenhagen-criteria een 'seculiere meetlat' heeft ontworpen om de vorderingen van kandidaat-leden aan te toetsen, maar dat uit de vele discussies en uitlatingen die de boodschap der Botsende Beschavingen prediken, blijkt dat men in werkelijkheid de islam als het probleem ziet; dat dus dat Westen, met haar zogenaamd elementaire erfenis van 'scheiding der machten', hier de partij is die politiek en religie niet gescheiden kan houden?

\subsection{WAARDEN ALS CULTURELE ERFENIS}

Hopelijk blijkt uit bovenstaande bedenkingen al hoe buitengewoon problematisch het denken in beschavingsblokken, en dus ook in een 'Europese beschaving' is. Het is een paradigma dat vooral grote praktische consequenties heeft, omdat Huntington het waardensysteem van humanisme, individualisme, democratie en mensenrechten als een verworvenheid van de historisch gegroeide 'westerse wereld' ziet en niet als onlosmakelijk deel van het moderniseringsproces. Hierdoor zijn ze in zijn ogen niet universeel, maar cultuurgebonden. De westerse waarden dienen met kracht en zelfvertrouwen verdedigd te worden (reden waarom Huntington het concept van de multiculturele samenleving 
afwijst), maar het is twijfelachtig of andere grote beschavingsblokken, zoals China of 'de islam', vatbaar zullen blijken voor een ontwikkeling naar hetzelfde soort moderniteit, gebaseerd op dezelfde onderliggende waarden. Met name de islam wordt voorgesteld als een ideologisch systeem dat zich uiteindelijk niet met democratische en humanistische waarden verdraagt (de conclusie waartoe ook een fundamentalist als Cemalettin Kaplan, de kalief van Keulen, was gekomen).

Deze benadering kan vanuit het oogpunt van Turkije op twee manieren bekritiseerd worden. In de eerste plaats kan in zijn algemeenheid gesteld worden dat het feit dat een filosofisch systeem zijn wortels heeft in de historisch gegroeide beschaving van één gebied niet in de weg staat dat datzelfde systeem buiten dat beschavingsgebied wordt overgenomen of zelfs universeel wordt. Als dat niet waar was, zou bijvoorbeeld de moderne wiskunde niet bestaan. Meer specifiek kan gezegd worden dat juist in het geval van het Osmaanse rijk en Turkije de modernisering de afgelopen anderhalve eeuw wel degelijk is samengegaan met de overname en geleidelijke internalisering van een waardensysteem dat zijn wortels in Renaissance, humanisme en Verlichting heeft. Al in 1839 werden liberale principes als de onaantastbaarheid van lijf en goed officieel door de sultan geproclameerd. Gelijkheid voor de wet van alle Osmaanse burgers werd al in 1856 officeel beleid. Een grondwet komt er in 1876 , slechts 28 jaar na de hervorming van de Nederlandse grondwet door Thorbecke, die van Nederland een parlementaire democratie maakte. De ontwikkeling van de democratische rechtsstaat in Turkije is een langdurig en moeilijk proces geweest met veel tegenslagen, maar het is onzin te beweren dat de 'westerse' waarden van democratie en mensenrechten wezensvreemd zijn aan Turkije.

\subsection{DE TURKSE ISLAM, DEMOCRATIE EN MENSENRECHTEN}

De vraag of islam, democratie en mensenrechten gecombineerd kunnen worden, heeft belangrijke praktische consequenties voor Turkije, een islamitisch land met de ambitie deel van de EU uit te gaan maken. Immers, de regeringsleiders van de EU hebben de Unie gedefinieerd als een waardengemeenschap. De waarden waarop de gemeenschap is gebaseerd, worden weerspiegeld in de criteria waaraan de kandidatuur van potentiële lidstaten wordt getoetst en die sinds 1993 zijn geformaliseerd in de zogenaamde 'Kopenhagen-criteria'. Ook hier vinden we democratie en mensenrechten terug als kernelementen. Geen van beide wordt in de stukken van de Unie eenduidig omschreven of gedefinieerd. Wat betreft het criterium 'democratie', betekent dit dat de Unie niet uitgaat van een absolute maatstaf voor democratisch bestuur. Van Dale geeft als definitie van democratie: 'een staatsvorm waarbij het volk zichzelf regeert en vrijelijk zijn meningen en wensen kan uiten' (Van Dale 1991: 621), maar dat begrip dekt natuurlijk een veelheid aan verschijningsvormen. De Unie hanteert dan ook niet één model, maar de zogenaamde Regular Reports hanteren wel een operationele definitie voor haar monitoring. In feite kunnen de opvattingen van de EU over wat de essentiële kenmerken van een aanvaardbaar democratisch systeem zijn alleen impliciet 
worden afgeleid uit de rapportages. Gezien de verschillende vormen van democratie die in Europa bestaan, hoeft het geen verwondering te wekken dat de rapportages in dit opzicht erg subjectief zijn. Er bestaat namelijk niet zoiets als een 'Europese democratie'. Dit blijkt zodra we de praktijk binnen de verschillende lidstaten onder de loep nemen. Nederland is in de ogen van zijn burgers een democratie, maar toch zijn sommige elementen in het Nederlandse bestuurssysteem (de monarchie, benoemde burgermeesters en commissarissen der koningin, dijkgraven) in bijvoorbeeld Amerikaanse of Franse ogen buitenissig en allerminst democratisch. Het ontbreken van een constitutioneel hof in de Nederlandse rechtsorde wekt in veel landen verbazing. Omgekeerd is het Franse verschijnsel van het parlementslid dat een dubbelfunctie heeft als burgemeester van een grote stad voor Nederlanders moeilijk in overeenstemming te brengen met opvattingen over behoorlijk bestuur en de positie van de Britse monarch als hoofd van de kerk moeilijk met die over secularisme. Dat de Bondsrepubliek Duitsland namens de kerken belasting int, vinden Turkse secularisten heel twijfelachtig.

Er is dus zelfs binnen Europa geen meetlat waaraan dit centrale criterium van Kopenhagen getoetst kan worden. We kunnen slechts uitgaan van een aantal minimumeisen waaraan een systeem dient te voldoen om als democratisch beschouwd te kunnen worden: eisen zoals vrije en eerlijke verkiezingen, vreedzame overdracht van de macht, scheiding van machten en het recht van de meerderheid in het parlement om een regering te vormen. Waar de rapportages van het Europees Parlement een veel gedetailleerder invulling geven aan de eisen op het gebied van democratie, bevinden zij zich op glad ijs.

Met de mensenrechten ligt dat anders. De mensenrechtendefinitie van de Regular Reports is gebaseerd op het Europese Verdrag voor de Rechten van de Mens (EVRM), vastgelegd in 1950 in Rome, dat gerelateerd is aan de door de Verenigde Naties in 1948 vastgelegde Universele Verklaring van de Rechten van de Mens, die historisch natuurlijk voortbouwt op de Franse Déclaration des droits de l'homme et du citoyen uit 1789, de Amerikaanse grondwet van 1787 en de Britse Bill of Rights van 1689 .

Is de islam, zoals die in Turkije wordt beleden, strijdig met deze, al dan niet eenduidig geformuleerde, basisprincipes? Om te beginnen is het natuurlijk onloochenbaar zo dat geloofssystemen die ieder voor zich pretenderen een absolute, want goddelijke, waarheid te vertegenwoordigen en deze in leefregels te vervatten, op gespannen voet staan met de pluriformiteit van een democratische samenleving. De drie grote openbaringsgodsdiensten jodendom, christendom en islam zijn potentieel juist het meest onverenigbaar met democratische pluriformiteit vanwege de centrale rol die het heilige boek, waarmee de geopenbaarde waarheid concrete vorm aanneemt, in het geloof speelt. Tegelijk kunnen we constateren dat de geschiedenis van de laatste tweehonderd jaar bewijst dat bewegingen die zichzelf geïnspireerd achten door een openbaring wel degelijk een actieve en constructieve rol kunnen spelen binnen een democratisch 
systeem. Voor het christendom wordt dit dagelijks aangetoond door de christendemocratische partijen in Europa en voor het jodendom zowel door de rol die belijdende joden hebben gespeeld in de Europese en Amerikaanse democratische politiek als door de geschiedenis van de staat Israël. Welke bezwaren men ook moge hebben tegen de bezettingspolitiek van Israël, het is ontegenzeggelijk een democratie.

Binnen de christelijke en joodse wereld bestaan natuurlijk minderheden die weliswaar functioneren binnen het democratisch bestel, maar die zich zozeer op de geopenbaarde waarheid en de goddelijke wet baseren dat hun ideologische uitgangspunten en soms ook de praktische uitwerking daarvan, op gespannen voet staan met het democratisch pluralisme en de mensenrechten. De Staatkundig Gereformeerde Partij in Nederland, die in feite een theocratie voorstaat en de grondwettelijk vastgelegde gelijkberechtiging van vrouwen met voeten treedt, is hiervan een voorbeeld, net als de radicale religieuze partijen voortgekomen uit de Aguddat Israel in Israël. Dit soort bewegingen wordt over het algemeen, ondanks hun betwijfelbare grondwettelijke legitimiteit, getolereerd zolang zij in de praktijk de spelregels van het democratisch systeem grotendeels erkennen. Problematischer zijn de groepen die zich baseren op een zo radicale en exclusieve interpretatie van de openbaring dat zij deelname aan het democratisch systeem afwijzen. Voorbeelden hiervan zijn de radicale sekten die in de Verenigde Staten het federale gezag afwijzen en de joodse groepen in Jeruzalem die de staat Israël niet erkennen. Deze randverschijnselen doen echter niets af aan het feit dat de grote massa der gelovigen zijn plaats in het democratisch en grotendeels seculiere systeem heeft gevonden.

Voor de islam ligt het op het eerste gezicht anders. Het is ontegenzeggelijk zo dat de wereld van de islam, van Marokko tot Indonesië, een democratisch tekort kent. Democratische politieke bewegingen met een islamitische signatuur hebben zich in het postkoloniale tijdperk niet of nauwelijks kunnen ontwikkelen en sinds de jaren zeventig zijn het vooral radicale buitenparlementaire groepen die zich tot spreekbuis hebben gemaakt van het maatschappelijke ongenoegen over verarming, corruptie en buitenlands-politieke debacles. Dit beeld lijkt Huntingtons these te bevestigen dat islam en democratie niet samengaan. Maar daarbij zouden we voorbijgaan aan het feit dat de oorzaak van dit genoemde 'democratische tekort' niet vanzelfsprekend inherent is aan 'de islam'. Zo hebben bijvoorbeeld de militaire elites die in Noord-Afrika en het Midden-Oosten na het vertrek van de koloniale mogendheden na de Tweede Wereldoorlog de macht overnamen de plaatselijke politieke en maatschappelijke krachten niet bij hun bewind willen betrekken. Zij wendden zich voor steun tot Washington en Moskou. Door op deze manier het plaatselijke politieke leven de kop in te drukken, werd de oppositie uitgeroeid en daardoor werd ruimte geschapen voor fundamentalisten. Het islamitisch fundamentalisme kan volgens Jansen (1998) dan ook verstaan worden als een poging de uitsluiting uit het politieke en openbare leven ongedaan te maken, waarbij hij erop wijst: "Extreem-nationalistische leiders als Al-Qadhdhâfî in Libië en Saddâm Husayn in Irak zijn [en waren] 
misschien wel bedreigend, maar ze zijn niet fundamentalistisch" (Jansen 1998: 24).

Kortom, het gebrek aan democratie in veel islamitische landen heeft veelal meer te maken met een autoritair regime, dat in de praktijk uit opportunisme misschien wel appelleert aan islamitische gevoelens, maar veelal zelf niet fundamentalistisch of sterk islamitisch is. Het zou niet juist zijn op grond van de situatie onder dit soort regimes te concluderen dat 'de islam' democratie uitsluit. Het lijkt hier beter om de zaken om te draaien en te zeggen dat een gebrek aan democratie de pluriformiteit van het religieuze landschap uitsluit.

Turkije vormt binnen de wereld van de islam vooralsnog een uitzondering. Sinds meer dan een halve eeuw kent dit land, met een bevolking waarvan meer dan 95 procent moslim zegt te zijn, een pluriform democratisch systeem. Er is in die periode viermaal een openlijk militair ingrijpen in de politiek geweest, maar er zijn ook vijftien nationale verkiezingen geweest, waarvan twaalf werkelijk vrij en eerlijk. Er bestaat een mondige middenklasse en een veelvormig medialandschap. Is de casus Turkije daarom een voorbeeld dat aantoont dat islam en democratie wel degelijk compatibel kunnen zijn? Of is Turkije een frontlijnstaat in de botsing tussen het Westen en de islam, waarin de krachten van democratie en islam elkaar in wankel evenwicht houden? Hebben we, met andere woorden, te maken met een synthese of met een patstelling?

Zoals eerder in paragraaf 2.1 uitgebreid is toegelicht, is dit laatste in de beleving van veel kemalistische secularisten in Turkije het geval. Zij zien zichzelf als de stoottroepen van het secularisme en de 'westerse' waarden, die een rijzend tij van islamitische reactie onder controle moeten houden. In die strijd zijn zij paradoxaal genoeg niet zelden bereid concessies op het gebied van democratie en mensenrechten te doen, om zo het grotere kwaad van een ondemocratische, op religieuze regelgeving gebaseerde maatschappelijke orde te voorkomen.

Hiermee miskennen de kemalisten niet alleen een aantal wezenskenmerken van de Turkse islam, maar ook de mate waarin het secularisatieproces van de laatste anderhalve eeuw wortel heeft geschoten. In paragraaf 2.1 hebben we laten zien hoe in de Turks-islamitische rijken de religieuze autoriteiten geïncorporeerd werden in het staatsbestel en er een modus vivendi ontstond waarbij staat (devlet) en religie ( $\mathrm{din}$ ) in een complexe onderlinge afhankelijkheidsrelatie kwamen te staan. We hebben gezien hoe juist in de zeshonderd jaar van de Osmaanse heerschappij dit systeem werd verfijnd en vervolmaakt. Hierdoor zijn de Turkse oelema, de islamitische schriftgeleerden, zeker op de hogere niveaus, altijd gedwongen geweest in te spelen op de veranderende politieke en maatschappelijke omstandigheden waarvoor het overheidsbeleid een oplossing moest zien te vinden die tenminste niet strijdig was met de islamitische wet. Het is aannemelijk dat dit bij de professionele beoefenaren van de Turkse islam een habitus van flexibiliteit en openheid heeft doen postvatten - een these die overigens al in de jaren vijftig door de islamoloog Cantwell-Smith is geponeerd. 
Vanaf de jaren dertig van de negentiende eeuw ondergaat de staat waarmee de Osmaanse godsdienstgeleerden in symbiose leven, een geleidelijk maar uiteindelijk diepgaand seculariseringsproces. Verzet daartegen van de kant van de hogere oelema is er in de negentiende eeuw nauwelijks geweest. Integendeel, het hervormingsproces werd door hen gesanctioneerd en belangrijke hervormers, zoals Ahmed Cevdet Pasja, de vormgever van het Osmaanse burgerlijk wetboek, hadden zelf een achtergrond als godsdienstgeleerde.

In de Turkse republiek is deze traditie voortgezet. De eerste generaties godsdienstgeleerden van de republiek, nu verenigd onder de vlag van het Presidium voor Religieuze Zaken, de Diyanet, steunden de religieuze politiek van de kemalisten, die erop was gericht de publieke rol van de islam zoveel mogelijk terug te dringen en van het geloof een kwestie van persoonlijke overtuiging en moraliteit te maken. De naoorlogse periode heeft weliswaar een veel grotere tolerantie ten opzichte van publieke manifestaties van religie gebracht, maar de seculiere staatsorde en het seculiere rechtssysteem zijn niet aangetast. De fundamentele boodschap van de staatsislam, zoals verkondigd door de Diyanet is ook niet veranderd. Om te zien wat die boodschap heden ten dage is, kunnen we een blik werpen op een van de meest verbreide publicaties van het presidium, de Cep İlmihali (zakcatechismus).

\section{$3 \cdot 5$ DE POSITIE VAN DE OFFICIËLE ISLAM}

Het onderstaande is gebaseerd op de Cep İslmihali van 20oo. Deze zakcatechismus bestaat uit drie hoofdstukken. Het eerste behandelt de islamitische geloofsleer, het tweede de gedragsleer. Het derde, in dit kader meest interessante hoofdstuk, heeft als titel: İsslam'da Ahlâk ('Islam en Ethiek') en is ingedeeld in vijf delen, respectievelijk de plichten van de gelovige jegens God en zijn profeet, jegens zichzelf, jegens familie en naasten, jegens vaderland en natie en jegens de mensheid (Soymen 2000: 95-123). Voor een oordeel in hoeverre de prediking van de officiële Turkse islam in overeenstemming is met westerse opvattingen over democratie en mensenrechten, zijn vooral de laatste drie categorieën verplichtingen van belang.

In de plichtenleer over familie en naasten is de belangrijkste plaats ingeruimd voor het huwelijk en het gezin. Deze 'instituties' worden in traditionele termen omschreven. Het huwelijk is aanbevelenswaardig. Wie niet trouwt, terwijl hij of zij daartoe wel in staat is, verzaakt zijn of haar plicht. Mannen moeten hun vrouwen onderwijzen, eren en zacht en beleefd behandelen, maar zijn wel de baas: "Thuis is de man het hoofd van het gezin" (Soymen 2000: 108-10). Het is op het moment van schrijven nog niet duidelijk in hoeverre bovenstaande passage in de publicaties van Diyanet gewijzigd is in het licht van de invoering van een nieuw burgerlijk wetboek in Turkije in 2001. In dat nieuwe wetboek is de passage over de man als hoofd van het gezin geschrapt en wordt bepaald dat de echtgenoten gezamenlijk het gezin leiden (Cumhuriyet, 22-6-2001). 
Het sterke staatsgebonden karakter van de officiële Turkse islam vinden we vooral terug in het hoofdstuk over de plichten jegens vaderland en natie. Het denken uit de school van de Turks-Islamitische Synthese (zie par. 2.1.6) is hier duidelijk nog steeds dominant, getuige uitspraken als: "De islamitisch-Turkse natie is een van de oudste, beroemdste, eervolste en meest verheven naties in de geschiedenis van de mensheid. De Turkse geschiedenis is vol met verheven heldendaden. De voedingsbron van deze ongeëvenaarde heldendaden is het geloof." En: "Vaderlandsliefde komt voort uit het geloof" (Soymen 2000: 115-17).

Vaderlandsliefde en nationale trots blijven ook geen abstracte begrippen. Ze worden vertaald in volgzaamheid: "Het hoofd buigen voor de wetten en voorschriften van de regering is een plicht. Zo beveelt ons boek, de Nobele Koran, het." Dit wordt in de catechismus nog verder geconcretiseerd in de plichten om belasting te betalen en in het leger te dienen: "Dienstplicht (...) is een voorschrift van het geloof." Dienen is uit religieus oogpunt dan ook aantrekkelijk, want: "De positie van een soldaat is in ons geloof hoog verheven. Als een soldaat sneuvelt, bereikt hij het martelaarschap. De graad van martelaarschap komt in het hiernamaals direct na die van het profeetschap." En: "Onder voorwendselen de dienstplicht ontduiken of deserteren is verraad, een laagheid en een grote zonde" (Soymen 2000: 115-17).

Hier staat tegenover dat we in het hoofdstuk over de plichten jegens de mensheid een discours aantreffen dat nauw aansluit bij hedendaagse Europese opvattingen over mensenrechten, die zijn geworteld in het liberalisme. Er wordt de nadruk op gelegd dat God de mens vrij geschapen heeft en dat de mens vrij is voorzover hij de vrijheid van anderen niet in gevaar brengt. De islam wordt voorgesteld als een religie die de natuurlijke rechten van de mens duidelijker heeft verkondigd dan enige andere gemeenschap, filosofie of wetenschap. De natuurlijke rechten waar de mens aanspraak op kan maken, worden gedefinieerd als: "Het recht op leven (...), het recht op vrijheid (...), het recht op [vrijheid van] denken (...) en het recht op het vormen van bezit” (Soymen 2000: 119-20).

Samenvattend kan gezegd worden dat de dominante stroming binnen de Turkse soennitische islam, de aan de staat gelieerde islam van de Diyanet, een vorm van islam reproduceert die gekarakteriseerd kan worden als een veilige middenweg. Het persoonlijke geloof en de individuele moraliteit worden verbonden met tamelijk traditionele maatschappelijke waarden, waarin soldidariteit en hiërarchie worden benadrukt. In dit opzicht lijkt de boodschap van de officiële islam op die van de christen-democratie in Europa: het gezin als hoeksteen van de samenleving en respect voor (traditionele) normen en waarden. Verbindingen met politiek worden uitgesloten, maar de religie wordt wel ingezet om loyaliteit aan de staat te bevorderen. De bewering, zoals die vaak wordt gedaan, dat de islam van de Diyanet een liberale islam is, gaat dan ook beslist te ver. Geheel in de Osmaans-Turkse traditie ademt het Presidium voor Religieuze Zaken een sfeer van realisme en flexibiliteit, maar zeker niet van vernieuwing. Gedurfde theologische interpretaties zijn er ver te zoeken. Turkije kent wel islamitische 
vernieuwers, mensen die concepten uit de moderne (westerse) filosofie en sociologie inzetten om tot een nieuw begrip van de religie te komen, maar zij bewegen zich buiten het apparaat van de staatsislam. Het gaat daarbij om mensen zoals de liberale theoloog Mehmet Aydın of de publicisten Ali Bulaç en Abdürrahman Dilipak, die zichzelf identificeren als 'moslimintellectuelen'.

In de discussies over mogelijke Turkse toetreding tot de EU wordt het bestaan van het Presidium voor Religieuze Zaken en de daarmee feitelijk bestaande staatscontrole over de religie, althans over de soennitische islam, vaak als een probleem gezien. Deze constructie lijkt immers haaks te staan op de gangbare Europese opvattingen over scheiding van kerk en staat. Wanneer we op deze manier naar de positie van de Diyanet kijken, vergeten we echter dat een instituut als de kerk in de wereld van de islam niet bestaat. Zoals we in hoofdstuk 2 hebben aangetoond, is in de geschiedenis van de islamitische wereld de zorg voor de religie altijd in hoge mate een taak voor de staat geweest. Er is dan ook geen lichaam waaraan de staat zijn taak op dit gebied zou kunnen overdragen. Aandringen op een terugtreden van de staat op religieus gebied is dan ook weinig realistisch. Daar staat tegenover dat in een Turkije dat deel wil uitmaken van een Europese waardengemeenschap, de boodschap die de Diyanet uitdraagt daarmee in overeenstemming moet zijn. Dat wil zeggen dat in die boodschap minder aandacht voor het belang van de staat en meer voor dat van het individu zou moeten doorklinken. Wellicht is het juist de binding van het religieus establishment aan de staat die een dergelijke koerswijziging mogelijk zou maken. De (democratiserende) staat zou er dan immers op kunnen aandringen bepaalde interpretaties van het geloof anders, ofwel liberaler in te vullen. Los hiervan is het zeker gerechtvaardigd dat ook de alevitische bevolkingsgroep in Turkije aanspraak maakt op een deel van de (uit belastinggelden betaalde) middelen voor religieuze zorg.

\subsection{DE STEM VAN DE OPPOSITIE}

Waar de officiële gezagsdragers van de islam, van hoog tot laag, geïncorporeerd zijn in het staatsapparaat, is het logisch dat het niet zij maar de veel minder in het web van de staat gevangen leiders van mystieke broederschappen zijn geweest die van tijd tot tijd het verzet tegen de seculariseringspolitiek van het late Osmaanse rijk en van de republiek hebben geleid (zie par. 2.2). Dit was het geval bij de opstanden van 1909 en 1925 en bij lokale incidenten in de jaren twintig en dertig. Het verklaart waarom de kemalistische republiek de ordes heeft verboden en waarom de kemalistische elite nog steeds met zo veel wantrouwen naar de broederschappen kijkt. Tegelijk dient gezegd te worden dat zowel de politieke partijen die uit de kring van de Nakşibendi-broederschap zijn voortgekomen als de Nurcu-beweging en haar vertakkingen zich eigenlijk niet gewaagd hebben aan een aantasting van de seculiere orde. De Nationale Orde Partij, de Nationale Heilspartij, de Welvaartspartij, de Partij van de Deugd en de Partij van de Gelukzaligheid, allemaal hebben ze geprobeerd via de stembus, via reguliere lokale en nationale verkiezingen invloed te verkrijgen. De verkiezingsprogram- 
ma's en de propaganda tijdens de campagnes bevatten weliswaar vele verwijzingen naar islamitische en traditionele waarden en normen, maar een expliciete verwijzing naar een herinvoering van islamitische wetgeving is nergens te vinden. Dat kan tactische redenen hebben (het zou immers in Turkije een strafbaar feit zijn), maar het is een feit dat ook daar waar de Welvaartspartij daadwerkelijk en voor langere tijd de macht in handen kreeg, zoals in Istanbul en Ankara na 1994, van een echte islamiseringspolitiek heel weinig te merken was.

Er zijn daarentegen wel veel tekenen dat ook de 'islamistische' oppositie begrippen als democratie en mensenrechten als referentiekader neemt, juist om daarmee haar positie in de grote conflicten met het secularistische staatsapparaat te verdedigen. De talloze vrouwelijke aanhangers van de Welvaartspartij die actie voerden tegen het verbod op de hoofddoek in het Turkse hoger onderwijs, deden dat met het argument dat hun mensenrechten werden geschonden. Zij eisten erkenning van hun recht hun godsdienstige overtuiging te tonen en beschuldigden de autoriteiten van discriminatie. Een argumentatie, kortom, die niet significant afwijkt van die van de islamitische vrouwen in het Franse hoofddoekendebat.

Erbakans politieke beweging heeft zoveel verschillende namen gekend omdat zij telkens weer is verboden. Toen de Welvaartspartij, met ongeveer eenvijfde van het Turkse electoraat achter zich, in 1998 werd verboden en Erbakan uit de politiek werd verbannen, was zijn reactie echter niet zijn volgelingen op te roepen tot revolutie en in naam van God bloed door de straten te laten stromen. Hij maakte de zaak aanhangig bij het Europees Hof (dat hem overigens later in het ongelijk stelde), terwijl zijn aanhangers conform de Turkse partijenwet een nieuwe partij oprichtten.

Behalve via de stembus proberen de islamitische bewegingen invloed te verwerven door aanhangers via politieke benoemingen op strategische plaatsen in het staatsapparaat te plaatsen (de zogenaamde kadrolaşma, waaraan overigens ook seculiere Turkse partijen zich schuldig maken) en door het opleiden en indoctrineren van nieuwe generaties van vooral ondergeprivilegieerde jongeren, die vervolgens van onderop het staatsapparaat binnendringen en daar voorvechters moeten worden van islamitische normen en waarden. Beide praktijken zijn zowel in kemalistische als in Europese ogen bedreigend, maar het is moeilijk vol te houden dat ze ondemocratisch zijn of mensenrechten schenden. In de politieke praktijk van 's werelds democratische supermacht, de Verenigde Staten, zijn beide schering en inslag. Men hoeve daarbij slechts te denken aan de benoemingen voor het Amerikaanse Supreme Court of aan de activiteiten van de Christian Coalition.

Als we meer over de ideologische uitgangspunten van de belangrijkste Turkse islamitische beweging willen weten, kunnen we Necmettin Erbakans publicatie Milli Görüş (Nationale Visie) uit 1975 als uitgangspunt nemen. De betiteling 'Nationale Visie' is de benaming voor de ideologische stroming die alle partijen 
van Erbakan, van de Nationale Orde Partij tot en met de Partij van de Gelukzaligheid, heeft voortgebracht en die ook in Duitsland en Nederland een wijdvertakt netwerk van moskeeën en verenigingen omvat.

In het boek zegt Erbakan met nadruk dat de beweging trouw is aan alle rechten en vrijheden die door de grondwet worden omschreven. Specifiek noemt hij de onaantastbaarheid van bezit en woning, de gelijkheid van alle personen voor de wet, en het recht op handel, reizen, berichten uitwisselen, vergaderen en demonstreren (Erbakan 1975: 31-3). In de passages over de positie van de vrouw ligt de nadruk, net als bij de Diyanet, op de rol van de vrouw als echtgenote en moeder. Werkende vrouwen moeten in staat gesteld worden om ook aan hun moederlijke plichten te voldoen. Tegelijk verdedigt de beweging het principe dat mannen en vrouwen gelijkelijk toegang tot kennis moeten hebben (Erbakan 1975: 38-9).

Veel aandacht wordt in het geschrift besteed aan de kwestie van het secularisme. In de ogen van Nationale Visie betekent secularisme in de ware betekenis van het woord (laiklik, van het Franse laïcité) dat eenieder vrijheid van denken, van geweten en van religieuze praktijk moet hebben. Het systeem in Turkije wordt dan ook gekwalificeerd als onecht secularisme, als een systeem waarbij door niet-gelovigen aan gelovigen hun mensenrechten worden onthouden. Erbakan dringt aan op het schrappen van artikel 163 van de strafwet, dat politiek gebruik van religie strafbaar stelt. In plaats daarvan wil hij een 'Wet ter Bescherming van de Mensenrechten' (Erbakan 1975: 51-6).

Opmerkelijk fel is Erbakan in zijn oordeel over de Europese Gemeenschap (en later de Unie), die hij afschildert als zijnde een neo-imperialistisch complot van joden en/of de katholieke kerk (Erbakan 1975: 235-264). Onder druk van de omstandigheden, met name het dragen van regeringsverantwoordelijkheid, hebben hij en zijn partij dit standpunt later wel verzacht, maar er is altijd een grote mate van ambivalentie gebleven in de opvattingen van Milli Görüş over Europa.

In dit opzicht is de houding van de AK-partij wezenlijk anders. De leiders van de AK-partij zijn vanaf 2001 niet alleen in de binnenlandse politiek opgeschoven van sterk religieus getint conservatisme naar een veel meer hybride vorm van ethisch conservatisme, nationalisme, vrijemarktdenken en technologische modernisering, maar ook hun buitenlandse politieke oriëntatie is wezenlijk veranderd. De AK-partij omarmt Europa juist als een garantie dat hun vorm van bottom-up-modernisering een kans krijgt in de confrontatie met het veel meer restrictieve en autoritaire moderniseringsmodel van de kemalistische staatselite. Om een iets concreter beeld te krijgen van de opvattingen van de AK-partij, is het zinvol om een blik te werpen op de A K Parti Seçim Beyannamesi, het verkiezingsmanifest van de partij en op het partijprogramma van 2003, getiteld: Herşey Türkiye İçin (Alles voor Turkije). 
In het document wordt heel sterk het geloof in 'ware' democratie benadrukt, met gelijke rechten op vertegenwoordiging voor iedereen: "Onze partij, die verschillen van geloof en cultuur als een verrijking voor het land ziet, vindt dat mensen met verschillende taal, religie, ras en sociale status zich op basis van gelijke wettelijke bescherming vrijelijk moeten kunnen uiten en als zodanig moeten kunnen deelnemen aan de politiek" (AK Parti 2003: 7). En verderop: "De AKPartij, die politieke partijen als wezenlijke elementen ziet van het democratische bestel, is tegen het sluiten van politieke partijen die opereren binnen het (grond)wettelijk kader" (AK Parti 2003: 7).

Het programma benadrukt verder dat de AK-partij weliswaar veel waarde hecht aan conservatieve normen en waarden, maar ook staat voor modernisering en verdere liberalisering van de economie, daarbij de staat in dienst stellend van de maatschappij, in tegenstelling tot een autoritaire bureaucratische top-downbenadering. Over toetreding tot de EU zegt zij: "Onze partij ziet het volledig lidmaatschap van de EU als een natuurlijke uitkomst van het moderniseringsproces" (AK Parti 2003: 8). De AK-partij stelt zich in het document volledig achter het lidmaatschap en de economische en politieke criteria van de Unie omdat, zo gelooft zij, maatschappij en staat gezamenlijk via dit pad van verdere modernisering nationaal en internationaal een sterkere positie kunnen verwerven. De economische en politieke Kopenhagen-criteria worden dan ook niet gepresenteerd als opgelegde maatregelen ter verkrijging van een toegangsbewijs, maar als objectieve criteria die onontbeerlijk zijn voor de vooruitgang van Turkije en zijn internationale positie. Binnenlandse tegenstanders van het lidmaatschap van de Unie worden op deze manier impliciet gebrandmerkt als tegenstanders van vooruitgang van Turkije. In deze redenering wordt een extreem nationalist door de AK-partij neergezet als iemand die juist de nationale belangen schaadt.

Een apart hoofdstuk behandelt de internationale afspraken met betrekking tot de fundamentele rechten en vrijheden van de mens. De AK-partij onderschrijft deze, ook weer deels in de context van het nationale belang in de globale arena, volledig en verklaart alles in het werk te zullen stellen om door middel van (grond)wetswijzigingen volledig te voldoen aan de internationale verdragen en specifiek aan de eisen die voortvloeien uit de Kopenhagen-criteria. Tevens wordt benadrukt dat dit verder gaat dan wetswijzigingen: "Het respecteren van fundamentele vrijheden en rechten is meer dan het vastleggen van garanties in grondwet en wetten, daarnaast moet inspanning verricht worden om deze wijzigingen werkelijk in de praktijk te brengen en als onlosmakelijke elementen te verankeren in onze politieke cultuur" (AK Parti 2003: 12).

Gelijke rechten voor vrouwen vormen voor de AK-partij een belangrijk punt waaraan, aan het einde van document, een aparte paragraaf wordt besteed onder het kopje Kadın Sorunlarn ('Problemen van Vrouwen'). Zwart op wit wordt gesteld dat vrouwen en mannen weliswaar samen de lasten des levens dragen, maar dat de vrouw in de praktijk niet de gelijkwaardige maatschappelijke status heeft waar zij recht op heeft. De belangrijkste problemen van vrouwen die de 
AK-partij constateert zijn: "economische problemen, laag of geen opleidingsniveau, (financiële) zorgen om de toekomst, huiselijk geweld en het ontberen van sociale zekerheid" (AK Parti 2003: 76), daarbij wel benadrukkend dat er grote regionale verschillen bestaan tussen stad en platteland. Vervolgens wordt gesteld: "Onze partij hecht belang aan het elimineren van problemen van vrouwen, aangezien [die problemen] het op gezonde wijze grootbrengen van nageslacht en het bewerkstelligen van geluk binnen de familie belemmeren" (AK Parti 2003: 76). Daarna wordt een opsomming gegeven van maatregelen die nodig zijn om elke vorm van ongelijkheid of discriminatie op te heffen. Een opvallend punt is: "In de gebieden waar zelfmoord onder vrouwen en moord op vrouwen wegens ethische gronden en het schenden van de eer [eerwraak] vaak voorkomt, moeten op vrouwen en hun families gerichte preventieve en educatieve maatregelen genomen worden" (AK Parti 2003: 76). Hiermee stelt de AK-partij dus dat de ongelijke positie van vrouwen en ernstige zaken zoals eerwraak niets met haar interpretatie van de islam te maken hebben en onacceptabel zijn.

Op dit punt werpt zich wellicht een vraag op. Moeten we nu de klaarblijkelijke gematigdheid van de islamistische 'oppositie' toeschrijven aan politiek opportunisme of aan voorzichtigheid? Zou, met andere woorden, als de tegendruk van de staat en vooral het leger vermindert, een andere en veel radicalere islamisering van de maatschappij worden nagestreefd? In een democratische politieke context zoals die van Turkije, waar stemmen tellen, leidt dat natuurlijk tot de vraag: zou een dergelijk radicaal programma kans maken op steun bij de bevolking?

\subsection{IS ER EEN VOEDINGSBODEM VOOR FUNDAMENTALISME?}

De term 'islamitisch fundamentalistisch' is in deze studie eerder (par. 2.4) gedefinieerd als zijnde de mensen met de wens de maatschappij (weer) volledig in te richten volgens de regels van de islamitische wetten en die daarbij (politiek) geweld in sommige gevallen niet schuwen. Een manier om inzicht te krijgen in deze 'wens' is het nagaan in hoeverre Turkse moslims zich vinden in dergelijke fundamentalistische ideeën. Aan de andere kant is het ook van belang om de mening van de Turkse islamitische bevolking te peilen met betrekking tot 'andersdenkenden'. Een islamitisch fundamentalist is immers van mening dat 'het Westen' met zijn systeem en gedachtegoed 'de islam' vijandig gezind is.

De onderstaande gegevens zijn gebaseerd op een onderzoeksrapport van TESEV, getiteld Türkiye'de din, toplum ve siyaset (Religie, maatschappij en politiek in Turkije) (Çarkoğlu en Toprak 200o). Dit onderzoek naar de religieuze attitudes van de Turkse bevolking geeft aan dat het bestaan van een Turkse voedingsbodem voor fundamentalisme onwaarschijnlijk is. Ongeveer eenderde $(35,2 \%)$ van de Turkse bevolking identificeert zichzelf in de eerste plaats als moslim, waarbij er een opvallende tegenstelling bestaat tussen stad en platteland en lager en hoger opgeleiden. Laagopgeleiden op het platteland en in de kleinere provinciesteden geven het vaakst aan dat zij zich in de eerste plaats als moslim beschouwen, terwijl dat percentage voor mensen die hoger onderwijs hebben genoten 
maar 10 procent is. 53 procent van de bevolking identificeert zich in de eerste plaats als burger van Turkije of als 'Turk'.

Als we kijken naar de manier waarop de Turken hun geloof beleven, zien we dat van de mannen minder dan de helft de verplichte vijf dagelijkse gebeden verricht, terwijl ongeveer tweederde deelneemt aan het vrijdagsgebed, althans zegt dit te doen. Dit duidt niet op een zeer grote geloofsijver. Daarnaast lijken de Turken een soepele definitie van het begrip 'moslim' te hanteren. Volgens 85 procent kan zelfs iemand die niet bidt nog als een moslim worden beschouwd. Iemand die alcohol drinkt (volgens strikt islamitisch recht een misdrijf dat gestraft wordt met geselslagen) kan dat volgens 66 procent nog, en een vrouw die haar hoofd niet bedekt kan volgens 85 procent ook als moslim worden beschouwd. Het lijkt er dus op dat uiterlijk vertoon en gedrag niet het belangrijkste criterium is waarop Turkse moslims hun geloofsgenoten beoordelen.

Een ander criterium is de vraag of een persoonlijke of zakelijke leefomgeving tussen moslims en niet-moslims als problematisch wordt beschouwd. Ruwweg gesproken geeft ongeveer de helft van de Turkse bevolking de voorkeur aan een leefomgeving waarin mensen naar de regels van de islam leven. Bij het zoeken van een huurhuis vindt 54 procent het van belang dat de buren religieus zijn, 37 procent vindt dat niet belangrijk. Bij de keuze uit twee 'buurtsupers' geeft 49 procent de voorkeur aan degene van religieuze signatuur, 39 procent deelt die mening niet. Wat vrienden betreft, 61 procent vindt het belangrijk dat die religieus zijn, 31 procent vindt dat niet belangrijk. Als het om het zakelijk leven gaat, is 49 procent het ermee eens dat iemand die religieus is, betrouwbaarder en eerlijker is dan een niet-gelovige, 37 procent is het daar niet mee eens. (Dit zou natuurlijk ook een belangrijke reden kunnen zijn om de voorkeur te geven aan de 'gelovige' buurtsuper.)

De grote massa van de Turkse moslims heeft een vrij tolerante houding tegenover andersdenkenden: 89 procent van de Turken denkt dat er ook onder andersgelovigen 'goede mensen' bestaan. 63 procent van de ondervraagden wil niet dat zijn of haar dochter met een niet-moslim trouwt, voor meer dan eenderde is dit dus geen onoverkomelijk probleem. Hierbij terzijde opgemerkt dat een moslimman volgens islamitisch recht gerust mag trouwen met een 'vrouw van het boek', maar dat dit voor moslimvrouwen een stuk problematischer is: van haar echtgenoot wordt geëist dat deze zich tot de islam bekeert.

Bij deze voorgaande cijfers moet overigens wel benadrukt worden dat de laatste vragen niet zijn uitgesplitst naar specifieke religie. Het zou dus goed kunnen dat de zogenaamde 'mensen van het boek' (joden en christenen) in de ogen van Turkse moslims beter uit de bus komen dan bijvoorbeeld hindoeïsten.

Over het cruciale punt van de herinvoering van de heilige wet in het familierecht is de opinie van de Turkse bevolking eenduidig, ofwel: niet doen! Slechts 10 procent is voorstander van het herstellen van het islamitisch huwelijk (en daar- 
mee het recht om vier vrouwen te trouwen), terwijl 14 procent de islamitische vorm van echtscheiding door verstoting graag weer ingevoerd zou zien.

De bovenstaande gegevens zijn natuurlijk maar een betrekkelijk willekeurige opsomming van getallen, maar het beeld dat eruit naar voren komt, is dat van een in meerderheid traditioneel gelovige, maar ook vrij tolerante en allerminst fundamentalistische bevolking. Als we het verlangen om de maatschappij weer in te richten op basis van de şeriat, de islamitische wet, als het hoofdkenmerk van fundamentalisme zien, kunnen we zeggen dat maximaal tussen de tien en vijftien procent van de Turkse bevolking vatbaar is voor een fundamentalistisch gedachtegoed.

Ook andere gegevens lijken in die richting te wijzen. In de verkiezingen van 2002 was het grote electorale success van de AK-partij juist te danken aan het feit dat de leiders van deze partij nadrukkelijk afstand namen van het islamistische gedachtegoed van Erbakan en de zijnen en hun partij profileerden als een brede middenpartij, die conservatieve waarden en normen combineerde met een geloof in de vrije markt, moderniteit en technologie. Van de kiezers die hun stem op de AK-partij uitbrachten, was een deel afkomstig van de partij van Erbakan, dus van de islamisten, maar ook de Nationalistische Actie Partij en de liberaalconservatieve Moederlandpartij verloren grote aantallen kiezers aan de nieuwe partij. De partij vertegenwoordigt dus inderdaad een brede coalitie en het is significant dat het een partij met dit profiel ook lukte de 'echte' islamisten van Erbakans Partij van de Gelukzaligheid in zijn eigen thuishaven, de als zeer religieus bekendstaande stad Konya, ruimschoots te verslaan (Yavuz 2003: 258).

De omvang van de steun voor de echt militante groepen is dan ook klein (zie par. 2.4). IBDA-C beschikt vrijwel zeker over niet meer dan enkele honderden toegewijde leden, met mogelijk enige duizenden sympathisanten. Het aantal sympathisanten van de Hizbullah is wel op twintigduizend geschat, maar dat lijkt een overdrijving. In Duitsland, waar meer dan drie miljoen Turken in betrekkelijke vrijheid en zonder de restricties die door een kemalistisch staatsapparaat worden opgelegd, hun politieke en religieuze voorkeur kunnen volgen, heeft de radicale 'Staat van het Kalifaat' nooit meer dan ongeveer zevenduizend aanhangers gekregen. Dat maakt deze organisaties natuurlijk niet ongevaarlijk. Voor terreuraanslagen, zo is gebleken, zijn immers maar enkele fanatici nodig. Maar het duidt er wel op dat zij geen voedingsbodem vinden in de massa van de Turkse bevolking. Dit maakt de situatie in Turkije fundamenteel anders dan die in veel Arabische landen en in Zuid- en Zuidoost-Azië.

\subsection{PLURALISME ALS ONDERDEEL VAN DEMOCRATISERING}

Democratie staat in westerse ogen veelal gelijk aan pluralisme, op diverse vlakken. We hebben het hier natuurlijk vooral gehad over het islamitische landschap van Turkije, maar ter afsluiting volgt een korte beschouwing over de mate van pluralisme in Turkije in bredere zin. 
Het Turkse politieke bestel kent democratische gebreken in zijn kiesdrempels, constitutionele beperkingen, patronagesystemen en corruptie. De voortdurende pressie van het staatsapparaat op de politiek is zeker een probleem, maar Turkije is wel een land waar de kiezers via de stembus een andere politieke groepering dan de regerende aan de macht kunnen brengen en waar de oppositie de macht vreedzaam over kan nemen. Stemmen heeft zin en er zijn duidelijke en levensvatbare politieke alternatieven. Een ander kenmerk van een democratisch gebrek is censuur. De censuur grijpt nog bijna dagelijks in in Turkije, wanneer kranten of televisiekanalen in de ogen van de autoriteiten hun boekje te buiten gaan. De raad voor de media (RтÜK) is, net als de raad voor het hoger onderwijs (YÖK), een van de verlengstukken van de staat waarmee die de burgermaatschappij breidelt. Vooral publicaties van mensenrechtenorganisaties en van Koerdische signatuur hebben te maken met voortdurende pesterijen. Niettemin kent Turkije toch een groot en rijkgeschakeerd medialandschap en zijn journalisten en redacteuren voortdurend bezig de grenzen van het mogelijke te verkennen. Het is in Turkije ondanks alle censuur en zelfcensuur mogelijk in een straatkiosk sterk contrasterende visies op actuele gebeurtenissen te vinden, te kopen en te lezen.

Ook op het gebied van de economie zijn tegenstrijdige elementen te zien. De economische ontwikkeling van Turkije is de laatste vijfentwintig jaar vaak een proces van hollen en stilstaan geweest. Een zeer dynamische particuliere sector, waaronder bijvoorbeeld die van toerisme of textiel, is daarbij vaak de tegenhanger geweest van een falend financieel beleid van de overheid, bijvoorbeeld in de vorm van slechte belastinginning en corruptie. De jaarlijkse groei van het bruto nationaal product heeft gefluctueerd tussen de plus negen procent en de min negen procent. Niettemin zijn alle sectoren van de Turkse maatschappij in deze periode welvarender geworden, en sommige spectaculair welvarender.

De geschetste pluriformiteit van politiek en media en de economische ontwikkeling zijn het product van een maatschappij die in de laatste eeuw een grote stedelijke middenklasse heeft zien ontstaan, waarvan de welvaart en het opleidingsniveau met name in de afgelopen 25 jaar met vallen en opstaan enorm zijn gegroeid. De opvattingen van het staatsapparaat, met hun zware nadruk op soevereiniteit en centralisme, lopen in toenemende mate uit de pas met de zich snel ontwikkelende burgermaatschappij, maar tegelijkertijd is datzelfde staatsapparaat (inclusief zijn 'islamtak', de Diyanet) wel de erfgenaam van een enorme bestuurlijke traditie van zo'n zevenhonderd jaar.

Wat de legitimiteit van de staat betreft, speelt een belangrijke rol dat Turkije nooit het slachtoffer is geworden van koloniale overheersing. De poging daartoe heeft de bevolking van het land succesvol verhinderd in de onafhankelijkheidsstrijd van 1919-1922. In het recente verleden (sinds 1918) heeft het land geen militaire nederlagen geleden. Hierdoor heeft de staat zijn legitimiteit in de ogen van de bevolking nooit verloren. Veel Turken hebben veel kritiek op hun land, maar zij identificeren zich sterk met hun land en zijn trots op wat Turkije tot stand heeft gebracht. 


\section{DE TURKSE POSITIE: NIET 'DANKZIJ DE ISLAM' EN OOK NIET 'ONDANKS DE ISLAM'}

Wanneer Turkije zijn status van, om met Huntington te spreken, 'verscheurd land' zou verliezen en hecht verankerd zou raken in Europa, is dat wel degelijk een hoopgevend signaal voor de islamitische wereld; een teken dat de 'Botsing der Beschavingen' geen realiteit is, maar een hersenschim en dat de verworvenheden van het Westen ook wel degelijk in een islamitisch land een plek kunnen krijgen. Het betekent echter niet dat het 'Turkse model' zomaar geëxporteerd kan worden naar andere islamitische landen. Daarvoor is de Turkse ervaring te veel bepaald door specifieke historische factoren. Ook psychologisch ligt het niet voor de hand dat de landen in het Midden-Oosten naar Turkije zullen kijken als zijnde een rolmodel. In de Arabische landen wordt Turkije nog steeds vooral gezien als de vroegere 'koloniale' overheerser en als een handlanger van het imperialistische Westen. De traditioneel warme, en de laatste tien jaar sterk aangehaalde banden van Turkije met de aartsvijand Israël versterken dat beeld alleen maar. In feite zijn de relaties van de Arabische landen met Europese landen als Spanje, Italië en Griekenland al heel lang veel warmer dan die met Turkije.

Tenslotte nog dit: deze studie gaat over de Turkse islam. Ze is geschreven om vast te stellen in hoeverre het feit dat Turkije een islamitische land is eventuele toetreding tot de Eu belemmert. Anders gezegd: of het concept van de 'Botsing der Beschavingen' opgaat. In dat concept wordt 'de islam' nu eenmaal als de beschaving gedefinieerd waarmee het Westen (en dus Europa) wordt geconfronteerd. De studie kan daarom gemakkelijk de indruk wekken dat religie een allesbepalende factor is in de ontwikkeling van Turkije. Dat is echter niet zo. Turkije is in veel opzichten een modern land, waar de van oorsprong westerse ideeën over democratie en mensenrechten wortel hebben geschoten. Dat heeft het land weliswaar niet te danken aan de islam, maar het is ook niet 'ondanks de islam'. Ook wanneer we naar de wijdere islamitische wereld kijken, moeten we de verleiding weerstaan, de misstanden daar te gemakkelijk aan de religie te wijten. Misschien kunnen we dit hoofdstuk daarom het beste afsluiten met een citaat van de meest vooraanstaande moderne theoloog van Turkije, Mehmet Aydın, gedaan in een toespraak op 25 april 2001.

"In een maatschappij waar de individuele rechten met de voeten worden getreden, wordt ook de morele dimensie van de samenleving aangetast en zelfs verhinderd. In de moslimwereld zijn er ernstige mensenrechtenproblemen en de leidende moslimklasse is eerder autoritair. Maar religie als een sociaal feit is slechts gedeeltelijk verantwoordelijk voor deze situatie. De wortels van dit probleem van autoritair bestuur moeten in de eerste plaats gezocht worden in de heersende politieke cultuur, in de ondraaglijke economische situatie, in de wirwar en de verstrikking van internationale betrekkingen en pas dan, misschien in het moderne islamitische denken en handelen.

Met andere woorden: religieus pluralisme kan alleen begrepen worden samen met alle andere betekenisvolle sociale factoren. In een maatschappij waar de rechtsstaat en sociale rechtvaardig- 
heid worden erkend en de vraag naar democratische deelname aan het bestuur wordt beantwoord, daar wordt een brede waaier van sociale rollen aan iedere burger toegekend. Geweld wordt systematisch verminderd en tenslotte wordt een algemene politieke cultuur van constructieve conflictbeheersing toegepast. Dan kan ook de religie en het religieuze leven de kans krijgen om echt religieus en spiritueel te zijn en bijvoorbeeld minder politiek en ideologisch. Maar als deze genoemde maatschappelijke omstandigheden ontbreken, dan kan er zich nooit een religieus pluralisme ontwikkelen, zelfs als er liberale tendensen zijn in het religieuze leven" (Mehmet Aydin 2001: http://www.fleuri.ugent.be/cie/CIE/maydinnli.htm 
DE EUROPESE UNIE, TURKIJE EN DE ISLAM 


\section{CONCLUSIE: DE TURKSE ISLAM EN DE EUROPESE} BESCHAVING

Voor de lezer die de voorgaande hoofdstukken van deze verkenning tot zich heeft genomen, zal de conclusie die hieruit voortvloeit, geen verbazing meer wekken.

In hoofdstuk 2 hebben we eerst laten zien dat de Turkse islam een lange traditie kent van symbiose met de staat en dat deze traditie de zogenaamde 'officiële' islam in Turkije een sterk pragmatisch en flexibel karakter heeft gegeven. Een belangrijk kenmerk van de islam in Turkije is daarnaast het grote aantal verschijningsvormen ervan. We hebben uitgebreid stilgestaan bij deze veelvormigheid en gewezen op het belang van de aanwezigheid van de grote alevitische minderheid, met haar gehechtheid aan secularisme en humanistische waarden. We hebben gezien hoe de grote islamitische bewegingen in Turkije die niet aan de staat zijn verbonden, zowel degene die nog als klassieke derwisjordes worden beschouwd als de neo-bewegingen, in grote meerderheid bewegingen zijn die een hang naar moderne wetenschap en techniek proberen te combineren met traditionele normen en waarden. Dat die traditionele normen en waarden als 'islamitisch' worden beleden en beleefd, maakt deze bewegingen nog niet tot fundamentalistische stromingen. Echt radicale fundamentalistische groeperingen zijn er in Turkije wel, maar ze zijn marginaal. De houding van de islamitische meerderheid ten opzichte van de minuscule christelijke en joodse minderheden is weliswaar problematisch, maar het feit dat religieuze vooroordelen haaks staan op de formele gelijkberechtiging van alle burgers is niet uniek voor Turkije. Hetzelfde kan gezegd worden voor de houding van Europeanen tegenover de islamitische minderheden in Europa.

In hoofdstuk 3 is eerst geprobeerd een antwoord te geven op de vraag in hoeverre Turkije cultureel tot Europa behoort. Eerst is geconcludeerd dat het concept van herkenbare beschavingsblokken niet werkt en dat de grenzen tussen verschillende beschavingen diffuus en poreus zijn. Tegelijk is gezegd dat de modernisering van Turkije wel degelijk en al heel lang ook europeanisering is geweest en dat de erfenis van de Verlichting en het liberalisme ook in Turkije wortel heeft geschoten. Vanuit dit vertrekpunt is vervolgens de vraag beantwoord of de Turkse islam zich verdraagt met politieke democratie en een begrip van mensenrechten zoals dat verwoord is in de Europese conventie en de conventie van de Verenigde Naties. Analyse van kernteksten van zowel de officiële staatsislam als de islamitisch geïnspireerde politieke massabewegingen laat ondubbelzinnig zien dat dit inderdaad het geval is. De documenten van de huidige regeringspartij refereren zelfs uitdrukkelijk aan deze conventies en nemen de Europese praktijk als maatstaf. Waar de uitgedragen waarden op gespannen voet staan met die van Europa, gaat het om een verheerlijking van de staat en het leger en daarnaast autoriteit in het algemeen, die op zich niets met de islam van doen heeft, al wordt de religie wel door de staat gebruikt om deze waarden te sacraliseren. 
Volledige ontkoppeling van staat en religie is in een islamitische context moeilijk voorstelbaar, maar aanpassing van de boodschap van de staatsislam in een meer ‘burgerlijke’ richting zal zeker nodig blijken.

Dat de boodschap van de 'mainstream'-islam in Turkije, zowel staatsgebonden als anderszins, gematigd, flexibel en redelijk tolerant is, hoeft geen verbazing te wekken. De religieuze attitudes van de Turkse bevolking, zoals die naar voren komen uit sociologische onderzoeken, geven ditzelfde beeld. Combineren we politieke gegevens zoals verkiezingsuitslagen en onderzoek naar illegale organisaties met de gegevens uit deze onderzoeken, dan lijkt het veilig te concluderen dat maximaal vijftien procent van de Turkse bevolking zich aangesproken voelt door (elementen van) het fundamentalistische gedachtegoed. De steun voor - de overigens verboden - bewegingen die hierbij ook het gebruik van geweld gerechtvaardigd vinden, is waarschijnlijk zeer gering.

Religieus en, meer in het algemeen, cultureel vertoont Turkije dus een aantal karaktertrekken die sterk overeenkomen met die van sommige delen van Europa. Dit is niet alleen verklaarbaar vanuit de lange geschiedenis van contacten met Europa en de bewuste ambitie van de Turkse elite om Europees te worden, maar ook vanuit de kenmerken van de hedendaagse Turkse maatschappij, met een grote en mondige stedelijke middenklasse, politiek pluralisme en een sterke welvaartsgroei. Dat de dominante godsdienst in Turkije de islam is, in plaats van het christendom, doet daaraan niets af. Het feit dat de overeenkomsten vaak eerder zijn met landen zoals Polen of Griekenland dan met Nederland ook niet. Het uitsluiten van Turkije op basis van culturele of religieuze criteria, zoals dat door Europese politici en publicisten die zich laten inspireren door de ideeën van Huntington gebeurt, is dan ook niet terecht. Het vermeende on-Europese karakter van Turkije is een constructie, gebaseerd op een uiterst wankele definitie van een Europese of 'westerse' beschaving en een slecht begrip van de Turkse werkelijkheid.

Daarmee wil overigens niet gezegd zijn dat er geen bedenkingen zijn tegen een Turks lidmaatschap van de EU. Argumenten met betrekking tot armoede, migratie en de spankracht van de Europese instellingen moeten serieus genomen worden. Daar gaat deze verkenning echter niet over. Die heeft alleen betrekking op het, naar onze overtuiging, ongefundeerde argument dat Turkije geen lid zou kunnen of moeten worden omdat het een land is waarvan het overgrote deel van de bevolking moslim is. 


\section{LITERATUUR}

Abu Manneh, B. (1979) 'Sultan Abdülhamid II and Shaikh Abdulhuda Al-Sayyadi' in Middle Eastern Studies, 15.

AK Parti (2003) Her şey AK Türkiye için. Seçim beyannamesi, Ankara: AK Parti.

Anderson, B. (1991) Imagined communities, Londen: Verso.

Aydın, M. (2001) http://www.fleuri.ugent.be/cie/CIE/maydinnlı.htm

Bali, R. (1999) Cumhuriyet yıllarında Türkiye Yahudileri. Bir türkleştirme serüveni (1923-1945), Istanbul: Iletişim.

Birge, J.K. (1937) The Bektaşi order of derwishes, Londen: Hartfort.

Braude, B. en B. Lewis (red.) (1982) Christians and Jews in the Ottoman Empire. The functioning of a plural society, New York: Holmes \& Meier.

Bruinessen, M. van (1996) 'Kurds, Turks and the Alevi revival in Turkey' in Middle East Report, 26, 3 .

Buitelaar, M. en J. ter Haar (red.) (1999) Mystiek. Het andere gezicht van de islam, Bussum: Coutinho.

Çamuroğlu, R. (1997) 'Some notes on the contemporary process of restructuring Alevilik in Turkey’ in Kehl-Bodrogi, Kellner-Heinkele, Otter-Beaujean (red.), Syncretistic religious communities in the Near East, Leiden: Brill, 25-34.

Cantwell Smith, W. (1957) Islam in modern history, Princeton: Princeton University Press.

Çarkoğlu, A. en B. Toprak (200o) Türkiye'de din, toplum ve siyaset, Istanbul: TESEV Yayınları.

Cumhuriyet (2001) 'Erkek artık evin reisi değil', 22 juni.

Deringil, S. (1998) The well-protected domains. Ideology and the legitimation of power in the Ottoman Empire 1876-19o9, Londen: I.B. Taurus.

Douwes, D. (1997) 'Richtingen en stromingen' in Henk Driessen (red.), In het huis van de islam, Nijmegen: Sun, 162-181.

Driessen, H. (red.) (1997) In het huis van de Islam, Nijmegen: Sun.

Dumont, P. (1984) 'The origins of Kemalist ideology' in Jacob M. Landau (red.), Atatürk and the modernization of Turkey, Boulder: Westview, 25-44.

Ekster, J. den (1990) Diyanet. Een reis door de keuken van de officiële Turkse Islam, Beverwijk: Centrum Buitenlanders Peregrinus.

Erbakan, N. (1975) Millî Görüş, Istanbul: Dergâh Yayınları.

Erdoğan, N. (2000) 'Kemalist non-governmental organizations. Troubled elites in defence of a sacred heritage' in Stefanos Yerasimos et al. (red.), Civil society in the grip of nationalism, Istanbul: Orient-Institut, 283-334.

Evren, K. (1986) Türkiye Cumhuriyeti Devlet Başkanı Orgeneral Kenan Evren’in söylev ve demeçleri: 1985-1986, Ankara: Başbakanlık.

Geoffroy, E. 'Tarika' in Encyclopaedia of Islam, New Edition, vol. x, Leiden: Brill, 243-6.

Georgeon, F. (red.) (2000) Les mots de politique de l'Empire Ottoman a la Turquie kemaliste, Parijs: EHESS/ESA 8032, CNRS.

Gezik, E. (200o) Alevi Kürtler, Ankara: Kalan.

Göle, N. (1996) The forbidden modern. Civilization and veiling, Michigan: The University of Michigan Press. 
Groot, A.H. de (1986) Nederland en Turkije. Zeshonderd jaar politieke, economische en culturele contacten, Leiden: Nederlands Instituut voor het Nabije Oosten.

Hanioğlu, M.S. (1995) The Young Turks in opposition, opposition, Oxford: Oxford University Press.

Hanioğlu, M.Ş. (1997) 'Garbcllar. Their attitudes toward religion and their impact on the official ideology of the Turkish Republic', Studia Islamica, 86, 2: 133-158.

Hobsbawm, E. (1990) Nations and nationalism since 1780. Programme, myth, reality, Cambridge: Cambridge University Press.

Hoebink, M. (1997) 'Het denken over vernieuwing en secularisatie' in Henk Driessen (red.), In het huis van de Islam, Nijmegen: Sun, 199-217.

Huntington, S. (2003) Botsende beschavingen. Cultuur en conflict in de $21^{\text {ste }}$ eeuw, Amsterdam: Anthos.

Huntington, S. (1996), The clash of civilizations and the remaking of the world order, New York: Simon \& Schuster.

Imber, C. (1997) Ebu's-su'ud: The Islamic legal tradition, Edinburgh: Edinburgh University Press.

Imber, C. (2002) The Ottoman Empire, 1300-1650. The structure of power, New York: Palgrave Macmillan.

Jansen, J.J.G. (1998) Nieuwe inleiding tot de Islam, Bussum: Coutinho.

Kafadar, C. (1995) Between two worlds. The construction of the Ottoman state, Berkeley: University of California Press.

Karpat, K.H. (red.) (200o) Ottoman past and today's Turkey, Leiden: Brill.

Karpat, K.H. (2001) 'Nursî' in Encyclopaedia of Islam. New Edition, vol. VIII, Leiden: Brill: 143-4.

Kehl-Bodrogi, K., B. Kellner-Heinkele en A. Otter-Beaujean (red.) (1997) Syncretistic religious communities in the Near East, Leiden: Brill.

Lewis, B. (1996) Het Midden-Oosten. 2000 jaar culturele en politieke geschiedenis, Amsterdam: Forum.

Mardin, Ş. (1998) Religion and social change in modern Turkey. The case of Bediüzzaman Said Nursi, New York: State University of New York.

Ocak, A. (1997) 'Un aperçu général sur l'hétérodoxie musulmane en Turquie' in Kehl-Bodrogi, Kellner-Heinkele, Otter-Beaujean (red.), Syncretistic religious communities in the Near East, Leiden: Brill: 195-204.

Olsson, T., E. en C.R. Özdalga (red.) (1999) Alevi kimliği, Istanbul: Tarih Vakfı Yurt Yayınları.

Özdemir, A. en K. Frank (20oo) Visible Islam in modern Turkey, Londen: Macmillan.

Parla, R. (1985) Türkiye Cumhuriyeti'nin uluslararası temelleri, Nicosia: private.

Poulton, H. (1997) Top hat, grey wolf and crescent, Londen: Hurst \& Company.

Şener, C. (1990) Alevilik olayı: toplumsal bir başkaldırının kısa tarihçesi, Istanbul: Alev Yayınevi.

Shankland, D. (1999) Islam and society in Turkey, Cambridgeshire: The Eothen Press.

Shindeldecker, J. (200o) Turkish Alevis today, www.isik.ch

Soymen, M. (2000) Cep ilmihali, Ankara: Diyanet İşleri Başkanlığı Yayınları.

Sunier, Th. (1998) Turkije. Mensen, politiek, economie, cultuur, Amsterdam: Koninklijk Instituut voor de Tropen.

Toprak, B. (1981) Islam and political development in Turkey, Leiden: Brill. 
Yavuz, M.H. (2003) Islamic political identity in Turkey, New York: Oxford University Press.

Yerasimos, S. et al. (red.) (200o) Civil society in the grip of nationalism, Istanbul: OrientInstitut.

Zarcone, Th. (2001) 'Tasawwuf. Among the Turks', Encyclopaedia of Islam. New Edition, vol. X, Leiden: Brill: 332-4.

Zürcher, E.J. (1995) Een geschiedenis van het moderne Turkije, Nijmegen: Sun.

Zürcher, E.J. (2000) 'Young Turks, Ottoman Muslims and Turkish nationalists. Identity politics 1908-1938' in K. H. Karpat (red.), Ottoman past and today's Turkey, Leiden: Brill: $150-179$.

Zürcher, E.J. (2000) 'The core terminology of Kemalism. Mefkûre, millî, muasır, medenî' in: F. Georgeon (red.) Les mots de politique de l'Empire Ottoman a la Turquie kemaliste, Parijs: EHESS/ESA 8O32 CNRS: 55-64.

Zürcher, E.J. (1997), 'Islam en politiek: Turkije' in Henk Driessen (red.), In het huis van de Islam, Nijmegen: Sun.

Zürcher, E.J., 'Ottoman sources of Kemalist thought', http://www.let.leidenuniv.nl/tcimo/tulp (working papers archive). 


\section{WEBSITES}

http://www.ict.org.il Great East Islamic Raiders Front (IBDA-C) (4-12-2003)

http://www.im.nrw.de Innenministerium NRw - 'Kalifatstat', 'Kaplan' (4-12-2003)

http://www.terrorism.com The Terrorism Research Center - 'Turkish Hizballah'

(3-12-2003)

http://www.let.leidenuniv.nl/tcimo/tulp 'Turkology Update Leiden Project' 


\section{RAPPORTEN AAN DE REGERING}

\section{Eerste raadsperiode (1972-1977)}

1 Europese Unie*

2 Structuur van de Nederlandse economie*

3 Energiebeleid

Gebundeld in één publicatie (1974)*

Milieubeleid (1974)*

5 Bevolkingsgroei (1974)*

6 De organisatie van het openbaar bestuur (1975)*

7 Buitenlandse invloeden op Nederland: Internationale migratie (1976)*

8 Buitenlandse invloeden op Nederland: Beschikbaarheid van wetenschappelijke en technische kennis (1976)*

9 Commentaar op de Discussienota Sectorraden (1976)*

10 Commentaar op de nota Contouren van een toekomstig onderwijsbestel (1976)*

11 Overzicht externe adviesorganen van de centrale overheid (1976)*

12 Externe adviesorganen van de centrale overheid (1976)*

13 Maken wij er werk van? Verkenningen omtrent de verhouding tussen actieven en niet-actieven (1977)*

14 Interne adviesorganen van de centrale overheid (1977)*

15 De komende vijfentwintig jaar - Een toekomstverkenning voor Nederland (1977)*

16 Over sociale ongelijkheid - Een beleidsgerichte probleemverkenning (1977)*

Tweede raadsperiode (1978-1982)

17 Etnische minderheden (1979)*

A. Rapport aan de Regering

B. Naar een algemeen etnisch minderhedenbeleid?

18 Plaats en toekomst van de Nederlandse industrie (1980)*

19 Beleidsgerichte toekomstverkenning Deel 1: Een poging tot uitlokking (1980)*

20 Democratie en geweld. Probleemanalyse naar aanleiding van de gebeurtenissen in Amsterdam op 30 april $1980^{*}$

21 Vernieuwingen in het arbeidsbestel (1981)*

22 Herwaardering van welzijnsbeleid (1982)*

23 Onder invloed van Duitsland. Een onderzoek naar gevoeligheid en kwetsbaarheid in de betrekkingen tussen Nederland en de Bondsrepubliek (1982)*

24 Samenhangend mediabeleid (1982)* 


\section{Derde raadsperiode (1983-1987)}

Beleidsgerichte toekomstverkenning

Deel 2: Een verruiming van perspectief $(1983)^{*}$

26 Waarborgen voor zekerheid. Een nieuw stelsel van sociale zekerheid in hoofdlijnen (1985)

27 Basisvorming in het onderwijs (1986)

28 De onvoltooide Europese integratie (1986)

29 Ruimte voor groei. Kansen en bedreigingen voor de Nederlandse economie in de komende tien jaar (1987)

30 Op maat van het midden- en kleinbedrijf (1987)

Deel 1: Rapport aan de Regering;

Deel 2: Pre-adviezen

31 Cultuur zonder grenzen (1987)*

32 De financiering van de Europese Gemeenschap. Een interimrapport (1987)

33 Activerend arbeidsmarktbeleid (1987)

34 Overheid en toekomstonderzoek. Een inventarisatie (1988)

\section{Vierde raadsperiode (1988-1992)}

35 Rechtshandhaving (1988)

36 Allochtonenbeleid (1989)

Van de stad en de rand (1990)

Een werkend perspectief. Arbeidsparticipatie in de jaren '90 (1990)

Technologie en overheid (1990)

De onderwijsverzorging in de toekomst (1991)

Milieubeleid. Strategie, instrumenten en handhaafbaarheid (1992)

42 Grond voor keuzen. Vier perspectieven voor de landelijke gebieden in de Europese Gemeenschap (1992)

43 Ouderen voor ouderen. Demografische ontwikkelingen en beleid (1993)

\section{Vijfde raadsperiode (1993-1997)}

44 Duurzame risico's. Een blijvend gegeven (1994)

45 Belang en beleid. Naar een verantwoorde uitvoering van de werknemersverzekeringen (1994)

46 Besluiten over grote projecten (1994)

$47 \quad$ Hoger onderwijs in fasen (1995)

48 Stabiliteit en veiligheid in Europa. Het veranderende krachtenveld voor het buitenlands beleid (1995)

49 Orde in het binnenlands bestuur (1995)

50 Tweedeling in perspectief (1996)

51 Van verdelen naar verdienen. Afwegingen voor de sociale zekerheid in de 21 e eeuw (1997)

52 Volksgezondheidszorg (1997)

53 Ruimtelijke-ontwikkelingspolitiek (1998)

54 Staat zonder land. Een verkenning van bestuurlijke gevolgen van informatie- en communicatietechnologie (1998) 


\section{Zesde raadsperiode (1998-2002)}

55 Generatiebewust beleid (1999)

56 Het borgen van publiek belang (2000)

57 Doorgroei van arbeidsparticipatie (2000)

58 Ontwikkelingsbeleid en goed bestuur (2001)

59 Naar een Europabrede Unie (2001)

60 Nederland als immigratiesamenleving (2001)

61 Van oude en nieuwe kennis. De gevolgen van ICT voor het kennisbeleid (2002)

62 Duurzame ontwikkeling: bestuurlijke voorwaarden voor een mobiliserend beleid (2002)

63 De toekomst van de nationale rechtsstaat (2002)

64 Beslissen over biotechnologie (2003)

65 Slagvaardigheid in de Europabrede Unie (2003)

66 Nederland handelsland. Het perspectief van de transactiekosten (2003)

67 Naar nieuwe wegen in het milieubeleid (2003)

\section{Zevende raadsperiode (2003-2007)}

68 Waarden, normen en de last van het gedrag (2003) 


\section{VERKENNINGEN}

Zevende raadsperiode (2003-2007)

1 Jacques Pelkmans, Monika Sie Dhian Ho en Bas Limonard (red.) (2003) Nederland en de Europese grondwet

2 P.T. de Beer en C.J.M. Schuyt (red.) (2004) Bijdragen aan waarden en normen

3 G. van den Brink (2004) Schets van een beschavingsoffensief. Over normen, normaliteit en normalisatie in Nederland

Uitgegeven bij Amsterdam University Press (www.aup.nl). 


\section{VOORSTUDIES EN ACHTERGRONDEN}

Hieronder worden de publicaties uit de WRR-serie Voorstudies en achtergronden opgesomd vanaf de vijfde raadsperiode. Een volledig overzicht van de voorstudies is beschikbaar op de WRR-website (http://www.wrr.nl) of aan te vragen bij het bureau van de WRR (070 - 3564625$)$.

\section{Vijfde raadsperiode (1993-1997)}

W.J. Dercksen e.a. (1993) Beroepswijs onderwijs. Ontwikkelingen en dilemma's in de aansluiting van onderwijs en arbeid

W.G.M. Salet (1994) Om recht en staat. Een sociologische verkenning van sociale, politieke en rechtsbetrekkingen J.M. Bekkering (1994) Private verzekering van sociale risico's ССнОВ (1995) Aspecten van hoger onderwijs. Een internationale inventarisatie T. van der Meij e.a. (1995) Ontwikkelingen in de natuur. Visies op de levende natuur in de wereld en scenario's voor het behoud daarvan L. Hagendoorn e.a. (1995) Etnische verhoudingen in Midden- en Oost-Europa H.C. Posthumus Meyjes, A. Szász, Christoph Bertram, W.F. van Eekelen (1995) Een gedifferentieerd Europa J. Rupnik e.a. (1995) Challenges in the East J.P.H. Donner (rapporteur) (1995) Europa, wat nu? R.M.A. Jansweijer (1996) Gouden bergen, diepe dalen: de inkomensgevolgen van een betaalbare oudedagsvoorziening W. Derksen, W.A.M. Salet (red.) (1996) Bouwen aan het binnenlands bestuur SEO/Intomart (1996) Start-, slaag- en faalkansen van hoger opgeleide startende ondernemers L.J. Gunning-Schepers, G.J. Kronjee and R.A. Spasoff (eds.) (1996) Fundamental Questions about the Future of Health Care H.B.G. Ganzeboom en W.C. Ultee (red.) (1996) De sociale segmentatie van Nederland in 2015 J.C.I. de Pree (1997) Grenzen aan verandering. De verhouding tussen reorganisatie en structuurprincipes van het binnenlands bestuur M.F. Gelok en W.M. de Jong (1997) Volatilisering in de economie

A.H. Kleinknecht, R.H. Oostendorp, M.P. Pradhan (1997) Patronen en economische effecten van flexibiliteit in de Nederlandse arbeidsverhoudingen

V100 J.P.H. Donner (1998) Staat in beweging

V101 W.J. Vermeulen, J.F.M. van der Waal, H. Ernste, P. Glasbergen (1997) Duurzaamheid als uitdaging. De afweging van ecologische en maatschappelijke risico's in confrontatie en dialoog

V102 W. Zonneveld en A. Faludi (1998) Europese integratie en de Nederlandse ruimtelijke ordening

V103 Verslag en evaluatie van de vijfde raadsperiode (1998)

\section{Zesde raadsperiode (1998-2002)}

V104 Krijn van Beek (1998) De ondernemende samenleving. Een verkenning van maatschappelijke verandering en implicaties voor beleid W. Derksen et al. (1999) Over publieke en private verantwoordelijkheden Henk C. van Latesteijn (1999) Land use in Europe. A methodology for policy-oriented future studies Aart C. Liefbroer en Pearl A. Dykstra (2000) Levenslopen in verandering. Een studie naar ontwikkelingen in de levenslopen van Nederlanders geboren tussen 1900 en 1970 
V108 Bart Wissink (2000) Ontworpen en ontstaan. Een praktijktheoretische analyse van het debat over het provinciale omgevingsbeleid

V109 H. Mommaas, m.m.v. W. Knulst en M. van den Heuvel (2000) De vrijetijdsindustrie in stad en land. Een studie naar de markt van belevenissen

V110 H. Dijstelbloem en C.J.M. Schuyt, red. (2002) De publieke dimensie van kennis

V111 M.C.E. van Dam-Mieras en W.M. de Jong, red. (2002) Onderwijs voor een kennissamenleving. De rol van ICT nader bekeken

V112 Wendy Asbeek Brusse, Harry van Dalen en Bart Wissink (2002) Stad en Land in een nieuwe geografie. Maatschappelijke veranderingen en ruimtelijke dynamiek

V113 G.A. van der Knaap (2002) Stedelijke bewegingsruimte. Over veranderingen in stad en land.

V114 F.J.P.M. Hoefnagel (2002) Internet en cultuurbeleid. Over de gevolgen van ICT voor het cultuurbeleid van de Nederlandse overheid

V115 Gabriël van den Brink (2002) Mondiger of moeilijker? Een studie naar de politieke habitus van hedendaagse burgers

V116 Willem Witteveen, Bart van Klink, met bijdragen van Wouter de Been en Peter Blok (2002) De sociale rechtsstaat voorbij. Twee ontwerpen voor het huis van de rechtsstaat

V117 Rein de Wilde, Nikki Vermeulen en Mirko Reithler (2003) Bezeten van genen. Een essay over de innovatieoorlog rondom genetisch gemodificeerd voedsel

\section{Overige publicaties}

Voor de eenheid van beleid. Beschouwingen ter gelegenheid van vijftig jaar Ministerie van Algemene Zaken (1987) Eigentijds burgerschap. WRR-publicatie onder leiding van H.R. van Gunsteren (1992)

Mosterd bij de maaltijd. 20/25 jaar WRR (1997)

De vitaliteit van de nationale staat in een internationaliserende wereld (2002) 